CARLA VOLTARELLI FRANCO DA SILVA

\title{
PLANEJAMENTO DO USO E OCUPAÇÃO DO SOLO URBANO INTEGRADO AO MAPEAMENTO DE ÁREAS COM RISCO DE INUNDAÇÃO
}

\author{
Dissertação apresentada à Escola \\ Politécnica da Universidade de São \\ Paulo para obtenção do título de \\ Mestre em Engenharia
}


CARLA VOLTARELLI FRANCO DA SILVA

\title{
PLANEJAMENTO DO USO E OCUPAÇÃO DO SOLO URBANO INTEGRADO AO MAPEAMENTO DE ÁREAS COM RISCO DE INUNDAÇÃO
}

\author{
Dissertação apresentada à Escola \\ Politécnica da Universidade de São \\ Paulo para obtenção do título de \\ Mestre em Engenharia \\ Área de concentração: \\ Engenharia Hidráulica e Ambiental \\ Orientadora: Professora Doutora Monica \\ Ferreira do Amaral Porto
}




\section{FICHA CATALOGRÁFICA}

\section{Silva, Carla Voltarelli Franco da}

Planejamento do uso e ocupação do solo urbano integrado ao mapeamento de áreas com risco de inundação / C.V.F. da Silva. -- São Paulo, 2013.

$164 \mathrm{p}$.

Dissertação (Mestrado) - Escola Politécnica da Universidade de São Paulo. Departamento de Engenharia Hidráulica e Ambiental.

1. Recursos hídricos 2. Enchentes urbanas 3 . Uso do solo 4. Sistema de informação geográfica 5 . Políticas públicas I. Universidade de São Paulo. Escola Politécnica. Departamento de Engenharia Hidráulica e Ambiental II. t. 
Aos meus pais,

os meus maiores mestres. 


\section{AGRADECIMENTOS}

À Prof. Dra. Monica Ferreira do Amaral Porto, pela orientação, conselhos, amizade e confiança durante todo o tempo.

Ao Prof. Dr. Arisvaldo Vieira Méllo Jr., pela amizade, incentivo e imensa ajuda na elaboração desta pesquisa.

Ao Prof. Dr. Rubem La Laina Porto, pela confiança e incentivo profissional, que me permitiram desenvolver este e outros trabalhos no LabSid.

Ao Prof. Dr. José Rodolfo Scarati Martins, pelas recomendações valiosas.

À Dra. Silvana Susko Marcellini, pelas palavras de sabedoria.

Ao Programa de Demanda Social da Coordenação de Aperfeiçoamento de Pessoal de Nível Superior (CAPES), pelo auxílio financeiro através da concessão de bolsas de estudo.

Aos professores e funcionários do departamento de Engenharia Hidráulica e Ambiental da Escola Politécnica da USP, pela convivência e apoio.

Ao engenheiro Cid Granado, do Departamento de Águas e Energia Elétrica, e ao colega de mestrado Julio Canholi, por acreditarem na importância deste trabalho e proporcionarem o acesso às informações essenciais para sua elaboração.

Ao amigo e colega de trabalho Cristiano de Pádua M. Oliveira, pela disposição e interesse em ajudar, me estimulando a querer aprender sempre mais.

Aos colegas do LabSid, Alexandre N. Roberto, André Schardong, André Sosnoski, Honório Lisboa, Satie Ishikawa, Roberto Oliveira e, em especial, Mariana Guimarães, Joaquin B. Garcia e João Rafael B. Tercini, pela amizade, conselhos e colaborações.

Aos demais engenheiros com quem tive o privilégio de trocar ideias durante este período e que sempre se dispuseram a ajudar, em especial Sidnei Ono, Flavio Conde e Rodrigo M. Lucci.

Aos amigos Emilio Francesquini, Sandra Morikawa, Camila Munhoz, Luciana Campos, Bruna Suzuki e Helena Chung, pela amizade irrestrita e incentivo intelectual.

Aos meus pais, Ari e Elenice, por todo amor e dedicação, e aos meus irmãos, Juliano e Paula, os melhores amigos de toda a vida.

Ao meu noivo Humberto Giuntoli, pelo amor, companheirismo e paciência, com quem eu tenho a honra de dividir a vida e o futuro. 
"Preparar o futuro significa fundamentar o presente."

(Antoine de Saint-Exupéry) 


\section{RESUMO}

Os padrões atuais de uso e ocupação do solo nas cidades brasileiras têm agravado as dificuldades enfrentadas pela população urbana e o poder público em eventos extremos de cheia. Neste contexto, a regulamentação do uso do solo aliada à identificação das áreas mais suscetíveis aos impactos ocasionados pelas inundações surge como importante estratégia para o desenvolvimento de políticas urbanas municipais. Este trabalho buscou elaborar um conjunto de medidas de intervenção para a regulamentação do uso do solo na área urbana do município de Atibaia, caracterizada pela ocupação desordenada e tendo se desenvolvido às margens do rio Atibaia e seus afluentes. As propostas apresentadas foram fundamentadas no mapeamento das inundáveis, por meio de análise hidrológica, para determinar a probabilidade de ocorrência dos eventos, e hidráulica, para a delimitação da mancha de inundação com base na aplicação do PCSWMM, que integra o modelo SWMM a ferramentas avançadas de geoprocessamento. Através de uma extensa análise dos fatores legais aplicáveis, foi possível identificar os desafios e as perspectivas do planejamento do uso do solo como ferramenta indispensável ao controle de inundações e o gerenciamento dos recursos hídricos. Como resultados, foram apresentadas análises das precipitações e vazões registradas na região, além do cruzamento do mapa de inundação de 100 anos de período de retorno a interfaces físicas e políticas relevantes, como áreas de preservação permanente, áreas de proteção ambiental, densidade demográfica e o próprio zoneamento urbanístico em vigor. Com base neste cenário, foram elencados critérios de ocupação do solo compatíveis com a probabilidade de ocorrência de cheias. As principais diretrizes consistem na remoção das edificações instaladas na zona de maior risco e na contenção da ocupação e adequação a padrões construtivos a prova de enchentes nas demais zonas com restrições.

Palavras-chave: Recursos hídricos. Enchentes urbanas. Uso do solo. Sistema de Informação Geográfica. Políticas públicas. 


\begin{abstract}
Current patterns of land use and occupancy in Brazilian cities have exacerbated the difficulties faced by the urban population and the government during extreme flood events. In this context, land use regulation combined with the identification of areas most susceptible to the impacts caused by flooding emerges as an important strategy for the development of local urban policies. This study aimed to develop a set of intervention measures for land use regulation in the urban area of the city of Atibaia, characterized by disordered occupation and developed along the Atibaia river and its tributaries. The suggestions were based on flood mapping carried through hydrologic analysis, to determine the probability of events occurrence, and hydraulics, for the delineation of flood extent based on the application of PCSWMM, which integrates SWMM model with advanced geoprocessing tools. Through an extensive analysis of applicable legal aspects, it was possible to identify challenges and prospects of land use planning as an indispensable tool for flood control and water resources management. The results address analyzes of rainfall and streamflow recorded in the region and the intersection between a 100-year flood map and relevant physical and political interfaces, such as permanent preservation areas, environmental protection areas, population density and the urban zoning currently in place. Based on this scenario, criteria of land use compatible with flooding were listed. The main guidelines consist of the removal of buildings installed in the greater risk areas and of the prevention of occupancy and inducements to adequate floodproof constructive patterns in other areas where restrictions are required.
\end{abstract}

Keywords: Water resources. Urban flooding. Land use. Geographic information system. Public policies 


\section{LISTA DE ILUSTRAÇÕES}

Figura 1 - Definições didáticas: enchente e inundação.

Figura 2 - Número de pessoas afetadas pelas inundações no Brasil entre 2000 e 2011 (adaptado de EM-DAT, 2012).

Figura 3 - Zoneamento de áreas inundáveis.

Figura 4 - Sugestão de ocupação compatível com o zoneamento de áreas inundáveis .30

Figura 5 - Localização da área de estudo.

Figura 6 - Imagens das enchentes ocorridas em janeiro de 2011 no município de Atibaia (KONIG, 2011). 39

Figura 7 - Fluxograma das etapas do mapeamento das áreas inundáveis. .40

Figura 8 - Exemplo de validação de dados de nível para o posto 54 do SAISP.......42

Figura 9 - Localização dos postos de monitoramento selecionados. 44

Figura 10 - Localização das seções topobatimétricas levantadas no estudo do DAEE (2011a).

Figura 11 - Ferramenta de preenchimento de depressões para a correção de dados numéricos de elevação

Figura 12 - Coleta de dados em campo. .50

Figura 13 - Tela para entrada de dados de caracterização de uma seção transversal no aplicativo PCSWMM.

Figura 14 - Evolução da população residente no município de Atibaia entre 1950 e 2010.

Figura 15 - Hidrografia principal e setores urbanos do município de Atibaia. 55

Figura 16 - Precipitações mensais registradas nos postos telemétricos selecionados. 60

Figura 17 - Níveis observados em 2009, 2010 e 2011 no posto 54 (Rio Atibaia em Atibaia).

Figura 18 - Vazões estimadas em 2009, 2010 e 2011 nos postos da rede telemétrica analisados

Figura 19 - Distribuição das vazões máximas no rio Atibaia, no município de Atibaia, para o posto 62670000 da ANA. 
Figura 20 - Permanência dos níveis observados entre 1\%/dez/2009 e 31/mar/2010 no posto 54 (Rio Atibaia em Atibaia).

Figura 21 - Contribuição dos reservatórios para as vazões ocorridas no rio Atibaia em dezembro de 2009. .66

Figura 22 - Comparação das elevações interpoladas para os diferentes MDT ao longo das seções topobatimétricas levantadas.

Figura 23 - Sobrelevação da superfície do terreno induzida pela altura da vegetação numa seção de rio.

Figura 24 - Aplicação da ferramenta de interpolação das seções topobatimétricas e detalhe do MDT resultante na calha do rio Atibaia. .72

Figura 25 - MDT gerado a partir das curvas de nível e dos levantamentos topobatimétricos. .73

Figura 26 - Curva-chave estimada no ponto de controle. .74

Figura 27 - Mancha de inundação e localização de pontos inundados observados na cidade de Atibaia para uma vazão de pico 64,48 m³.s. .76

Figura 28 - Definição da zona de passagem de enchentes .78

Figura 29 - Mancha de inundação para uma vazão de 100 de período de retorno e delimitação da zona de passagem de enchentes. .79

Figura 30 - Mancha de inundação e áreas de preservação e proteção. .90

Figura 31 - Mancha de inundação e zoneamento urbanístico. .92

Figura 32 - Mancha de inundação e densidade populacional. .93

Figura 33 - Mapa de risco .94

Figura 34 - Identificação das áreas de risco alto e muito alto. .98

Figura 35 - Zoneamento de uso e ocupação do solo proposto para as áreas inundáveis no município de Atibaia ao longo do rio Atibaia. 102 


\section{LISTA DE TABELAS}

Tabela 1 - Dados necessários para a elaboração de mapas de inundação de cidade (TUCCI, 2009).

Tabela 2 - Identificação das estações telemétricas selecionadas.

Tabela 3 - Parâmetros das equações IDF para as estações selecionadas. .42

Tabela 4 - Curvas-chave dos postos fluviométricos do SAISP .43

Tabela 5 - Coeficiente de Manning .53

Tabela 6 - Quadro legislativo vigente que trata do planejamento do uso do solo urbano

Tabela 7 - Distribuição das vazões máximas no rio Atibaia, no município de Atibaia, para o posto 62670000 da ANA.

Tabela 8 - Níveis e vazões máximos registrados no posto 54 (Rio Atibaia em Atibaia) entre 2009 e 2011 e períodos de retorno associados. 64

Tabela 9 - Elevação média nas seções topobatimétricas a partir dos diferentes MDTs.

Tabela 10 - Critérios para definição do risco. 91

Tabela 11 - Estimativa do risco por setor censitário inundado. .95

Tabela 12 - Sugestão de elementos para regulamentação do zoneamento de uso e ocupação do solo proposto para as áreas inundáveis no município de Atibaia ao longo do rio Atibaia. 103

Tabela 13 - Critérios para construções à prova de enchentes, a serem incluídos na regulamentação do zoneamento proposto para as áreas inundáveis no município de Atibaia. 


\section{SUMÁRIO}

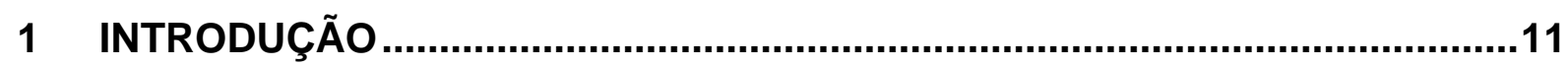

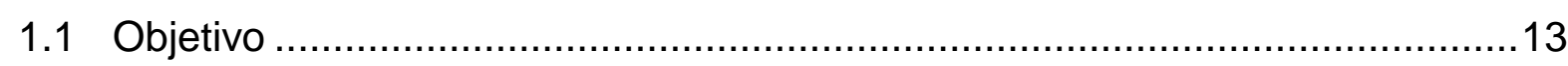

2 REVISÃO BIBLIOGRÁFICA.................................................................14

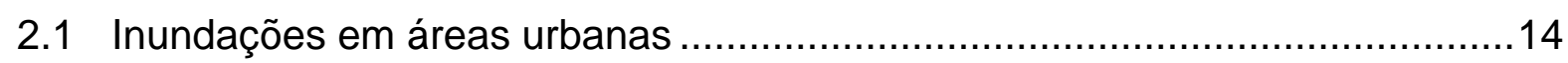

2.2 Medidas para controle de inundações ....................................................... 18

2.3 Zoneamento das áreas de inundação ………….......................................20

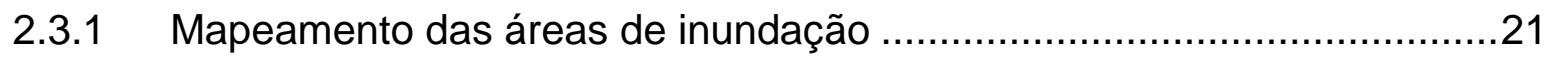

2.3.2 Zoneamento das áreas de risco e definição da ocupação .......................27

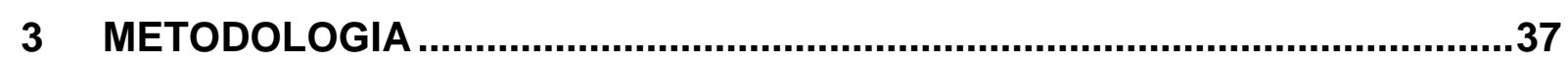

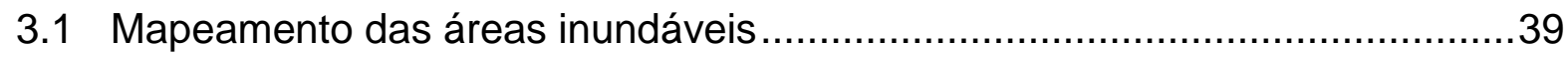

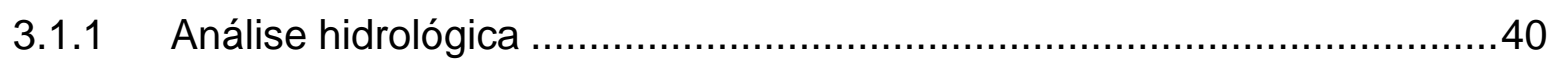

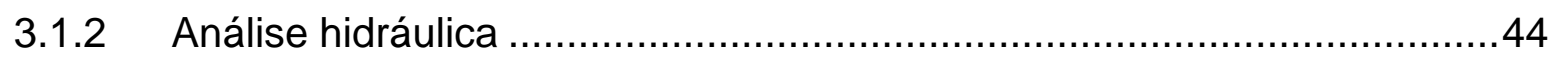

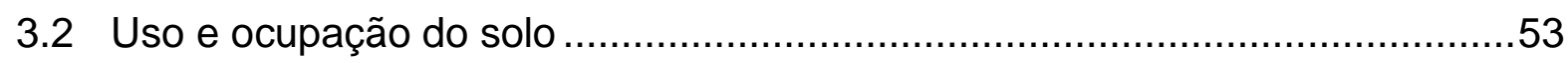

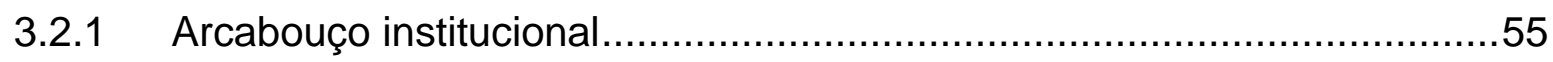

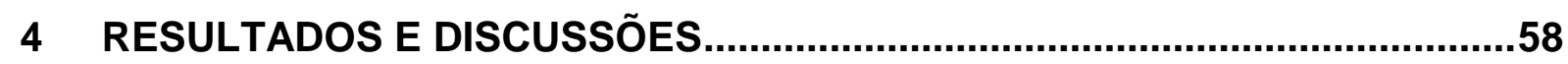

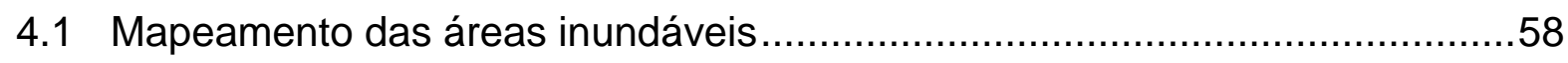

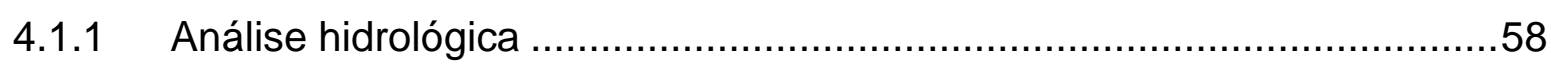

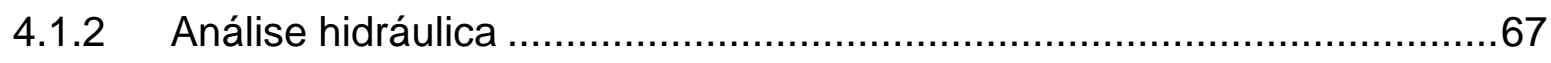

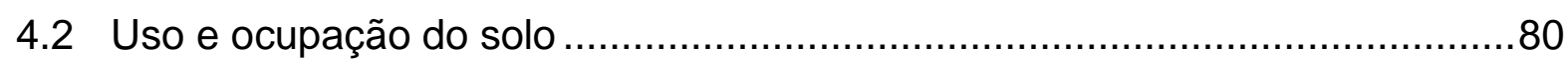

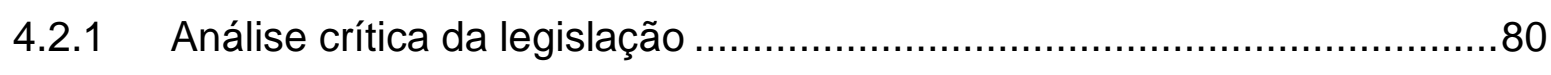

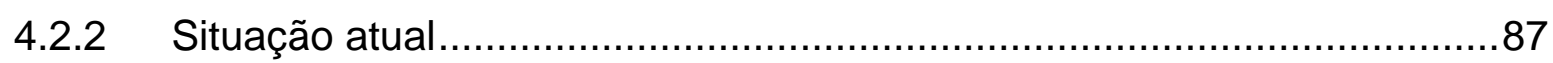

4.2.3 Proposição de medidas de intervenção................................................99

5 CONCLUSÕES E RECOMENDAÇÕES ...................................................108

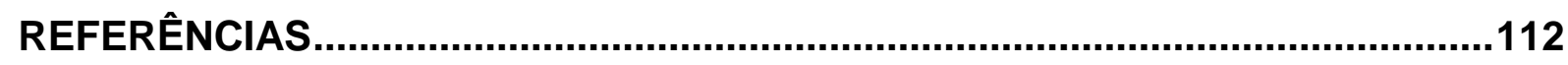

APÊNDICE A - PRINCIPAIS REFERÊNCIAS LEGISLATIVAS ..........................119 


\section{INTRODUÇÃO}

Em períodos chuvosos, é comum acompanharmos na imprensa manchetes que destacam os prejuízos causados pelas enchentes em diferentes partes do mundo, sejam áreas rurais ou metropolitanas. Os desdobramentos decorrentes destes e outros desastres naturais, como terremotos, furacões e tsunamis, estão, por sua vez, diretamente ligados ao tratamento que a sociedade e o poder público conferem às áreas sujeitas a estes eventos.

As inundações constituem-se de processos naturais relacionados à dinâmica dos corpos d'água, cujos efeitos podem ser intensificados por intervenções humanas, através das condições de escoamento aplicadas à bacia, sendo que toda interferência urbana representa uma alteração sobre as condições naturais. O regime de cheias, no entanto, não deve remeter sempre a efeitos nocivos, uma vez que é sabido que o extravasamento de rios, em determinadas áreas rurais, é fundamental para garantir a fertilização natural de suas margens. Para que a inundação seja, de fato, prejudicial, é preciso que a população permaneça ocupando as áreas de várzea (BRITO, 1926). Ocupações inadequadas podem não só comprometer as condições de escoamento, agravando ainda mais as intensidades das inundações, como também estão sujeitas a impactos consideravelmente superiores àqueles de um ambiente planejado, além de exporem mais pessoas às zonas de risco.

De acordo com Tucci (2006), as enchentes em áreas urbanas ocorrem devido à ocupação de áreas ribeirinhas e aos processos de urbanização, também responsáveis pelas inundações localizadas. O desenvolvimento urbano, que geralmente ocorre de forma desordenada nas grandes cidades brasileiras, pode alterar as condições de escoamento, com o aumento da área impermeabilizada, carência de obras de drenagem, canalização de rios e obstruções do canal de escoamento, agravando os impactos das precipitações mais frequentes. As instalações nas regiões de várzea sofrem, naturalmente, com maior frequência as consequências da elevação dos níveis d'água. Quando ocorre um longo período sem cheias, a população cria uma sensação de aparente segurança, o que estimula a ocupação das áreas inundáveis que, devido ao fato de serem geralmente 
ocupadas pela população de baixa renda, apresentam alto grau de vulnerabilidade (BRASIL, 2007).

O controle de inundações deve abranger uma combinação de medidas que podem ser classificadas como estruturais e não estruturais e envolvem, respectivamente, alterações diretas no sistema fluvial e artifícios de convivência da população com estes eventos. Este convívio é necessariamente conflituoso e especial atenção deve ser atribuída às medidas não estruturais, dentre as quais se destaca o zoneamento de áreas de risco. Esta ferramenta consiste na delimitação das áreas suscetíveis às inundações relacionando-as à vulnerabilidade das edificações nelas instaladas e, quando incorporada às políticas municipais, deve servir de base para o planejamento de uso e ocupação do solo. Também podem se associar ao zoneamento mecanismos de controle e correção do uso do solo, como a remoção e realocação da população ribeirinha, visando à ocupação segura das margens dos rios e córregos.

Em relação ao desenvolvimento histórico dos aglomerados urbanos, Tucci e Bertoni (2003) explicam que o homem sempre procurou se localizar próximo aos corpos d'água, devido às suas utilidades para transporte e saneamento e, por esta razão, as cidades se desenvolveram ao longo de rios e costas litorâneas. Os autores constaram, no entanto, que, devido à própria experiência dos moradores mais antigos, a população procurava alojar-se nas regiões mais altas, buscando conviver de forma segura com as inundações.

O conceito de ocupação segura associado à identificação das áreas inundáveis deve fundamentar a regulamentação para uso e ocupação do solo e as restrições não devem se limitar às questões habitacionais: instalações destinadas a serviços essenciais e o armazenamento de produtos perigosos também devem estar alocados em regiões livres de inundações. Do mesmo modo, sistemas viários e de saneamento devem contar com recomendações específicas, quando alocados nas influências de inundações. Por outro lado, parques e áreas recreativas são boas opções para as áreas onde o risco é mais eminente. Em regiões de menor risco, edificações destinadas a fins comerciais, industriais e até mesmo residenciais podem ser toleradas, desde que obedeçam a padrões de construção específicos, capazes de prevenir eventuais impactos causados pelas inundações.

Dentro deste contexto, torna-se fundamental a realização de estudos que delimitem as áreas de inundação e definam, com base no cruzamento com a 
identificação dos diferentes usos do solo nas regiões de várzea, as zonas de maior risco. Uma vez mapeados e hierarquizados os riscos, é razoável estabelecer critérios rigorosos de ocupação para que se possam implantar as medidas de controle indispensáveis à garantia da ocupação segura das margens de rios e córregos, atuando tanto no planejamento de áreas a serem desenvolvidas, como na correção dos espaços já consolidados.

As regulamentações são definidas principalmente para proteger a integridade e o bem-estar da população, além de minimizar os danos materiais em caso de ocorrência de cheias e garantir que a implantação de novos empreendimentos não prejudique as condições de escoamento da bacia, agravando ainda mais os problemas causados pelas enchentes. Ainda, em casos frequentes, onde a possibilidade de atuação em ambientes muito complexos é bastante limitada, o monitoramento das condições meteorológicas aliado a sistemas de previsão de alerta de enchentes deve ser contemplado como complemento à garantia da segurança da comunidade local.

Para este trabalho, foi escolhido o estudo de caso do município de Atibaia, localizado no interior do Estado de São Paulo. Esta escolha se explica devido à forma com que se deu o desenvolvimento urbano do município, às margens do rio Atibaia, e as recentes inundações que têm causado grande incômodo à população da região, o que evidencia a falta de planejamento do uso do solo especialmente nas áreas inundáveis.

\subsection{Objetivo}

O objetivo deste estudo é propor critérios para a regulamentação do uso e ocupação do solo com base na integração do mapeamento de áreas ribeirinhas inundáveis a fatores legais e institucionais, em áreas urbanas com pouca disponibilidade de dados e ocupação desordenada.

Desta forma, espera-se contribuir para a estruturação de ferramentas úteis ao planejamento do uso e ocupação do solo urbano em função do risco de inundação, critério que deve orientar a elaboração de políticas urbanas e habitacionais, como os planos diretores das cidades. 


\section{REVISÃO BIBLIOGRÁFICA}

\subsection{Inundações em áreas urbanas}

Os conceitos "enchente" e "inundação" têm sido frequentemente empregados como sinônimos, sendo que não há consenso sobre estas definições na literatura. $O$ Ministério das Cidades (BRASIL, 2007) propõe duas definições didáticas: enchente é a "elevação temporária do nível d'água em um canal de drenagem devida ao aumento da vazão ou descarga", equivalente à "cheia"; enquanto inundação corresponde ao "processo de extravasamento das águas do canal de drenagem para as áreas marginais (planície de inundação, várzea ou leito maior do rio) quando a enchente atinge cota acima do nível máximo da calha principal do rio". Sendo assim, uma enchente pode ou não causar inundação. A distinção entre os dois termos a partir destas definições pode ser mais bem observada através da Figura 1.

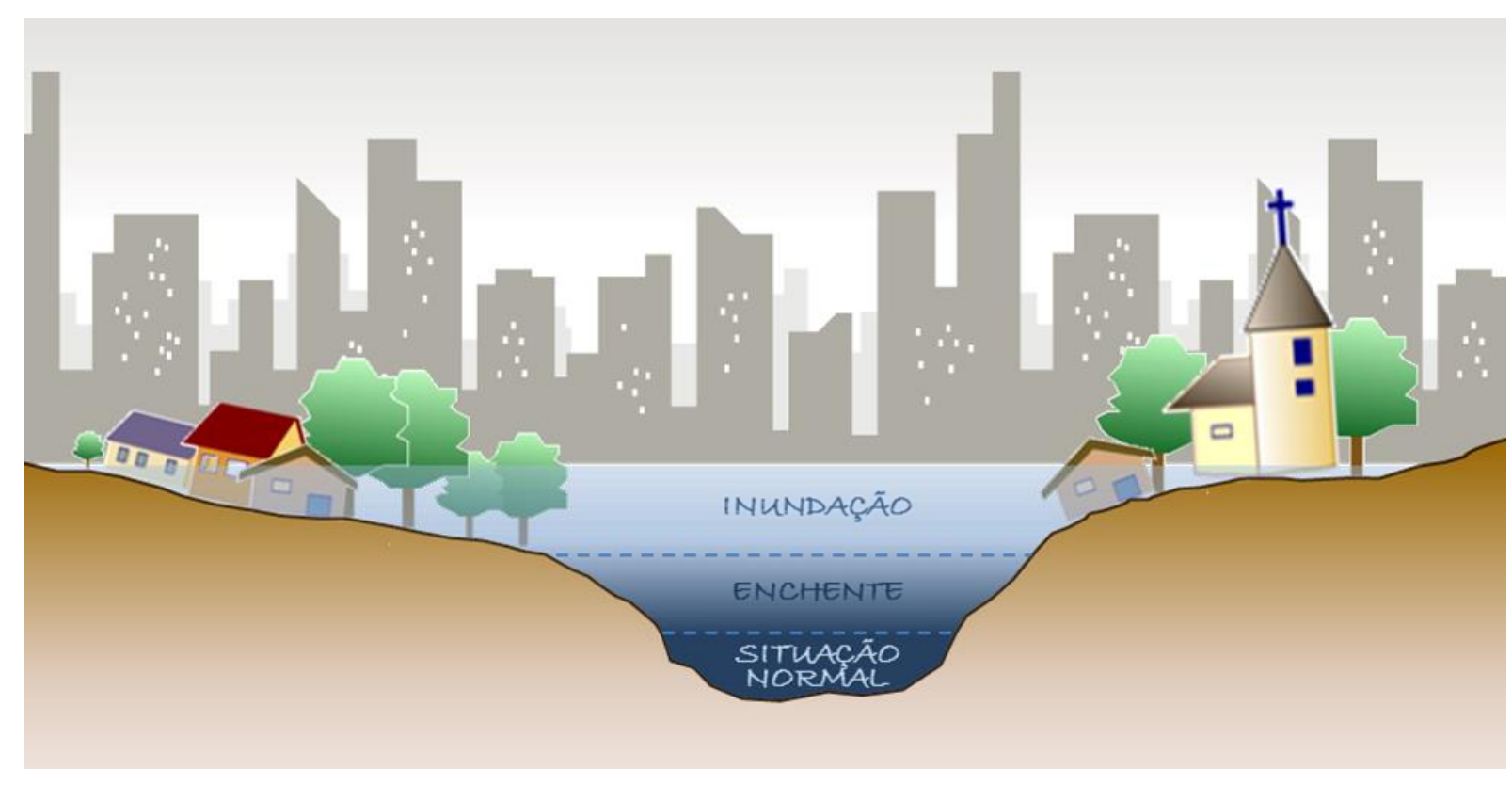

Figura 1 - Definições didáticas: enchente e inundação.

As inundações, ou seja, os processos de extravasamento, têm sido, com frequência, motivo de grande preocupação para as autoridades. No Brasil, entre os anos de 2000 e 2011, estes eventos foram responsáveis pela morte de 2.278 pessoas, afetando mais de 8,2 milhões de indivíduos, sendo que, só em 2011, mais 
de 3,7 milhões de pessoas foram afetadas por estes fenômenos no país (EM-DAT, 2012). A Figura 2 apresenta a evolução do número de pessoas afetadas pelas inundações no Brasil nos últimos anos.

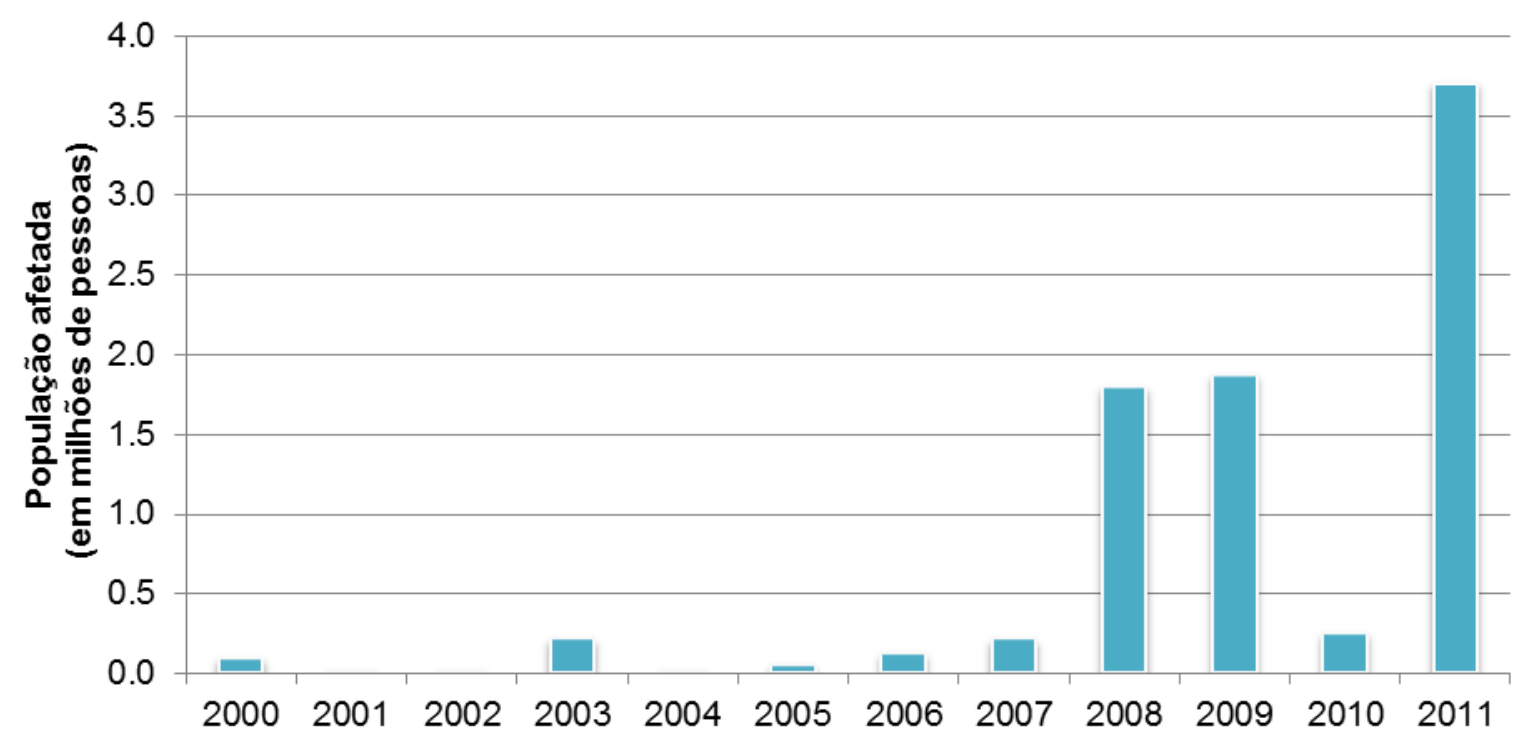

Figura 2 - Número de pessoas afetadas pelas inundações no Brasil entre 2000 e 2011 (adaptado de EM-DAT, 2012).

As enchentes ocorridas na última década não representam um fato novo; salvo raras exceções, anualmente, as temporadas de chuvas castigam diversas regiões do país. A situação se repete em várias partes do mundo, mas, especialmente em países subdesenvolvidos, os prejuízos humanos e materiais são agravados devido à falta de planejamento do uso do solo.

As inundações podem ser classificadas em dois tipos, que podem ocorrer isoladamente ou de forma combinada: inundações de áreas ribeirinhas e inundações devido à urbanização (TUCCI, 2006). O processo de inundação devido à urbanização decorre das modificações impostas ao escoamento superficial em razão do desenvolvimento urbano, como a impermeabilização do solo, a construção de rede de condutos pluviais e, ainda, obstruções ao escoamento, como pontes, aterros e acúmulo de resíduos. De acordo com Tucci e Bertoni (2003), as inundações decorrentes do processo de urbanização têm sido mais frequentes recentemente devido ao acelerado crescimento das cidades, enquanto os registros de inundações em áreas ribeirinhas são mais antigos. Estas, por sua vez, ocorrem de forma natural e estão relacionadas à intensidade e frequência das precipitações, não sofrendo grandes influências de restrições ao escoamento impostas pelo desenvolvimento 
urbano, sendo que, nestes casos, o controle da ocupação nas áreas de risco se apresenta como o principal mecanismo de gestão.

Tucci (2009) explica que o fenômeno das inundações ribeirinhas ocorre quando a precipitação é intensa e o volume que chega ao canal do rio é superior à sua capacidade de drenagem. Os impactos relacionados a estas inundações estão, por sua vez, diretamente relacionados a quatro elementos, destacados por White (1942):

- à probabilidade de ocorrência destes eventos;

- às características da planície de inundação;

- ao nível de ocupação das áreas de várzea; e, por fim,

- à adaptação da ocupação humana devido ao risco de inundação.

A relação existente entre a probabilidade da ocorrência destes eventos com o grau de vulnerabilidade do sistema receptor e seus efeitos caracteriza a definição de risco. Os dois últimos elementos citados por White (1942) refletem a condição de vulnerabilidade da população local. Vendruscolo (2007) conclui que a apreciação da vulnerabilidade indica que os impactos destes fenômenos naturais têm, de alguma forma, componentes antrópicos e sociais inerentes.

Um estudo realizado pelo Departamento de Águas e Energia Elétrica do Estado de São Paulo (DAEE, 2001) estima as externalidades econômicas associadas às enchentes na Região Metropolitana de São Paulo (RMSP). A metodologia de avaliação de custos levou em conta os danos causados aos bens e propriedades, interrupção ou atrasos nos deslocamentos, o tempo perdido pelos passageiros e motoristas durantes as horas de tráfego e demais prejuízos. O estudo conclui que o custo total de enchentes na RMSP varia de $R \$ 11,8$ a $R \$ 68,9$ milhões para episódios de cheia entre 2 e 30 anos de recorrência.

Os impactos das inundações sobre a população não se limitam a prejuízos materiais e a interrupções das atividades econômicas nas áreas inundadas, mas também têm reflexo no cenário da saúde pública. Em relação à qualidade da água, um problema que agrava este cenário no período de chuvas é a carga difusa. $O$ escoamento superficial tem capacidade de carregar cargas poluidoras, encontradas na superfície, bastante significativas, provenientes das mais diversas atividades, alcançando rios e lagos e constituindo importantes fontes de degradação dos corpos d'água (BARROS et al., 2005). Assim, a questão da limpeza pública e políticas de resíduos sólidos têm impacto direto sobre o efeito causado pelas inundações. Além disso, restrições e normas de segurança relativas ao descarte ou armazenamento 
de produtos perigosos devem ser enfatizadas, principalmente em áreas ribeirinhas, onde a população está mais sujeita aos impactos da poluição de forma geral, de modo a preservar a saúde da comunidade local e a qualidade das águas.

Du et al. (2010) classificam como consequências diretas das inundações afogamentos, lesões por detritos, contaminação química e hipotermia, e indiretas as doenças infecciosas, como leptospirose, hepatites $A$ e $E$ e doenças diarreicas, que ocorrem pela ingestão ou contato com a água contaminada. Neste último grupo, os autores ainda incluem problemas relacionados à má nutrição e doenças relacionadas à miséria e ao deslocamento das pessoas que ficaram desabrigadas. No caso do Brasil, o acúmulo das águas da chuva também facilita a ocorrência de dengue.

A postura tradicional adotada no país, no entanto, torna o problema ainda mais complexo, sendo cada vez maiores as dificuldades encontradas para a adoção de uma solução sustentável. A ausência ou atraso de políticas habitacionais contribui para o desordenamento do processo de desenvolvimento das cidades na maioria dos centros urbanos. Além disso, as medidas de combate às inundações estão fundamentadas em um conjunto de soluções estruturais isoladas e de caráter emergencial e corretivo, privilegiando interesses políticos em detrimento dos interesses da população, sem que haja um arranjo institucional fortalecido que permita a implantação de medidas eficazes e definitivas (TUCCI; BERTONI, 2003). White (1942) lembra que soluções que garantam a integridade da comunidade não precisam englobar necessariamente estruturas físicas; é preciso, no entanto, que haja um planejamento de modo a permitir a convivência da sociedade com as inundações, minimizando seus impactos.

Em uma análise realizada com dados da UNESCO (United Nations Educational, Scientific and Cultural Organization), Mendiondo (2005) estima que 96\% dos investimentos feitos pela comunidade internacional na gestão de riscos e desastres são de caráter emergencial e reconstrutivo, enquanto apenas $4 \%$ são gastos em prevenção. No caso específico das inundações, o autor revela ainda que cada dólar investido em prevenção é capaz de reduzir em até 25 dólares de prejuízos sofridos.

Devem ser considerados também os custos intangíveis no caso de óbitos provocados por causas diretas ou indiretas das inundações. Neste sentido, é prudente ressaltar a necessidade de se executar todo investimento necessário para 
colocar em prática as ações de controle e prevenção, a fim de evitar perdas humanas, além de todos os benefícios subsequentes.

\subsection{Medidas para controle de inundações}

As medidas para o controle das inundações são classificadas em estruturais e não estruturais. As medidas estruturais consistem em obras de engenharia que visam reduzir o risco de enchentes, enquanto as medidas não estruturais permitem reduzir os prejuízos decorrentes das enchentes, devido a uma melhor convivência da população com estes eventos (TUCCI, 2009). Um sistema efetivo de combate às inundações deve fundamentar-se em ambos os aspectos - redução do risco de enchentes e dos impactos causados - e, portanto, abranger um conjunto que envolva medidas estruturais e não estruturais.

As medidas estruturais podem ter caráter extensivo ou intensivo. As medidas extensivas tem efeito na bacia, sendo capaz de alterar as relações entre precipitação e vazão, como controle da cobertura vegetal e o controle da erosão que envolve reflorestamento, pequenos reservatórios, estabilização de margens e melhores práticas agrícolas (TUCCI; BERTONI, 2003), além de obras que aumentem a capacidade de infiltração e percolação da bacia. A aplicação destas medidas, no entanto, é impraticável para grandes áreas, sendo recomendável para pequenas bacias (com menos de $10 \mathrm{~km}^{2}$ de área) (BRASIL, 2006).

As medidas estruturais intensivas são recomendadas para bacias médias e grandes e podem apresentar elevado nível de dificuldade de aplicação. Diques e polders, por exemplo, apesar de promoverem alto grau de proteção de uma área, sujeitam a mesma a impactos maiores no caso de seu rompimento e devem ser complementados por um sistema de previsão e alerta para evitar que seu colapso produza perdas humanas (BRASIL, 2006). Outros exemplos de medidas intensivas são os reservatórios de controle de cheias, que, em alguns casos, podem ser aproveitados para usos múltiplos de recursos hídricos. Estas obras podem aproveitar a topografia local, mas, de acordo com Tucci e Bertoni (2003), demandam elevados custos de construção e desapropriações. Modificações na morfologia do canal também são medidas intensivas de alto custo e visam incrementar a 
capacidade de escoamento do canal, reduzindo a ocorrência de extravasamentos, por meio do aumento da seção transversal ou redução de sua rugosidade (BRASIL, 2006).

Devido a limitações físicas e econômicas, as medidas estruturais não são projetadas para oferecer uma proteção completa, ou seja, contra a maior enchente possível (TUCCI, 2009), sendo que medidas não estruturais devem, portanto, dar sustentabilidade às estruturais.

As medidas não estruturais buscam minimizar as perdas permitindo uma melhor convivência da comunidade com as cheias e têm características preventivas. São exemplos de medidas não estruturais: sistemas de previsão e alerta de inundações, seguro contra inundações, zoneamento das áreas inundadas, além de medidas de proteção individual (BRASIL, 2006). Sistemas de previsão e alerta necessitam de obtenção e processamento de dados em tempo real, sendo a previsão realizada por meio de modelos matemáticos, e devem estar atrelados a um plano de ação em conjunto com a Defesa Civil, enquanto o seguro contra enchentes assegura uma proteção econômica adicional para os prejuízos causados pelas cheias (TUCCl; BERTONI, 2003). O zoneamento de áreas inundadas será tratado no tópico a seguir, que também irá abordar a questão das medidas de proteção individual.

O custo de implementação de medidas estruturais é, em geral, mais elevado que o custo de medidas não estruturais. Em razão destes fatores, a partir de meados da década de 1960, países mais desenvolvidos e de maior experiência no trato das questões de inundações vêm dando ênfase a medidas não estruturais, que permitem que a população conviva com o risco das enchentes, otimizando o gerenciamento dos riscos. As várzeas de inundação passaram a ser objeto de regulamentação, sofrendo restrições quanto à sua ocupação e ao tipo de obras (POMPÊO, 2000) e, embora não evitem as inundações, estas medidas geralmente conseguem reduzir sensivelmente a vulnerabilidade aos danos provocados pelas inundações. 


\subsection{Zoneamento das áreas de inundação}

O zoneamento das áreas de inundação se caracteriza como uma medida não estrutural de controle de enchentes e consiste no estabelecimento de critérios rigorosos de uso e ocupação do solo com base no risco de enchente; ou seja, por meio da análise de eventos extremos para a identificação das áreas mais suscetíveis aos impactos ocasionados pelas inundações, auxiliando o desenvolvimento de políticas urbanas municipais voltadas ao adequado gerenciamento dos recursos hídricos.

Neste contexto, o mapeamento das áreas de inundação é essencial para a elaboração de planos emergenciais e também para 0 planejamento do desenvolvimento da região em longo prazo (RABINDRA; SHIGENOBU; TOSHIKAZU, 2008) e consiste em uma importante ferramenta de suporte à tomada de decisão para a regulamentação do uso do solo e licenciamento de atividades como escavações, aterramentos, construções, remoção de vegetação ribeirinha, armazenamento de materiais perigosos, entre outros.

O ordenamento do uso do solo não deve ser considerado como medida exclusiva de proteção contra enchentes, uma vez que deve estar aliado a outras medidas, estruturais e não estruturais, de combate às inundações, como a manutenção das condições de escoamento dos rios, construção de reservatórios, sistema de previsão e alerta contra enchentes e sistemas de seguro contra enchentes, além de adaptações dos padrões construtivos. Cada medida deve ter sua viabilidade e eficácia avaliadas, mas é fundamental que se combine o planejamento do desenvolvimento urbano a outras alternativas que visem minimizar os impactos causados pelos períodos de cheia.

Tucci (2009) define as etapas necessárias para a aplicação desta ferramenta, que serão aqui agrupadas em dois conjuntos: (i) mapeamento das áreas de inundação, com base no risco das enchentes, e (ii) zoneamento das áreas de risco (ou definição da ocupação), com base no levantamento da ocupação nestas áreas. 


\subsubsection{Mapeamento das áreas de inundação}

O mapeamento é a base para estabelecer critérios rigorosos de uso e ocupação do solo para que se possam implantar as medidas de controle indispensáveis à garantia da ocupação segura das margens de rios e córregos. O grau de complexidade e precisão das metodologias para se delimitar áreas sujeitas a inundações pode, no entanto, variar de acordo com a finalidade de cada estudo e relaciona-se também à disponibilidade e consistência das informações necessárias. A escolha dos procedimentos a serem aplicados requer conhecimento sobre a bacia a ser analisada, definição clara dos objetivos do estudo e conhecimento técnico para aplicação e calibração dos métodos (USACE, 2010). Aplicativos sofisticados de simulação computacional devem ser utilizados somente por técnicos com bons conhecimentos em modelagem hidráulica.

Uma maneira simplificada de mapear áreas suscetíveis a inundações é sugerida na obra Mapeamento de Riscos em Encostas e Margens de Rios (BRASIL, 2007), publicada com o intuito de capacitar equipes técnicas para constituir sistemas municipais de gerenciamento de riscos, articulados com as políticas locais. A publicação associa áreas de risco de enchente e inundação aos assentamentos precários alocados nas margens dos corpos d'água e sugere um procedimento simplificado para a identificação preliminar de tais áreas, com base no histórico de enchentes e inundações envolvendo tais assentamentos ou, ainda, na identificação das ocupações marginais aos cursos d'água principais, com o auxílio de fotos aéreas, plantas cartográficas ou outros materiais disponíveis. A metodologia proposta apresenta pouca complexidade e baixos custos de execução, possibilitando, portanto, a hierarquização dos riscos das áreas previamente identificadas, os quais devem ser classificados de acordo com seguintes critérios:

- potencial destrutivo dos processos hidrológicos, em função de sua energia cinética, capacidade de transporte de material sólido e raio de alcance;

- condições de vulnerabilidade das moradias, relacionadas aos padrões construtivos; e

- distância das moradias ao eixo de drenagem.

Para resultados mais precisos, o processo de mapeamento consiste basicamente em delimitar a área que é coberta por água, com base no cruzamento de 
informações da superfície do terreno e do nível d'água estipulado para determinado evento (MERWADE et al., 2008). Tucci (2009) elenca os tipos de dados necessários para a elaboração de tais estudos, apresentados na Tabela 1.

Tabela 1 - Dados necessários para a elaboração de mapas de inundação de cidade (TUCCI, 2009).

\begin{tabular}{cl}
\hline ITEM & DESCRIÇÃo \\
\hline (a) & Nivelamento da régua a um zero absoluto \\
(b) & Topografia da cidade no mesmo referencial absoluto de régua linimétrica \\
(c) & $\begin{array}{l}\text { Estudo de probabilidade de inundações de níveis para uma seção na } \\
\text { proximidade da cidade }\end{array}$ \\
(d $)^{*}$ & Níveis de enchentes, ou marcas ao longo da cidade que permitam a definição \\
$(\text { de })^{*}$ & Seções batimétricas ao longo do rio no perímetro urbano \\
$(\mathrm{f})^{*}$ & Cadastramento das obstruções ao escoamento ao longo do trecho urbano
\end{tabular}

* Itens desnecessários em casos onde a declividade da linha d'água ao longo da cidade é muito pequena e não há arroios significativos no perímetro urbano.

As cheias são frequentemente medidas em termos de magnitude e probabilidade estatística de ocorrência. A cheia de 100 anos, que constitui o critério adotado em diversas regiões do mundo, apresenta $1 \%$ de chance de ser igualada ou excedida em qualquer ano e tem um intervalo de recorrência médio de 100 anos.

Nos Estados Unidos, é obrigação legal da Agência Federal de Gestão de Emergências norte-americana (FEMA, Federal Emergency Management Agency) identificar e mapear as áreas inundáveis do território nacional. A Agência divide os procedimentos para a confecção destes estudos em quatro fases (FEMA, 2003):

- Avaliação das necessidades de mapeamento: para áreas que já possuem as manchas de inundação mapeadas, é avaliada a adequação de tais produtos e, se for o caso, a necessidade de atualização dos mesmos. Em casos da não existência de tais estudos, este procedimento é feito para determinar se a comunidade está sujeita a inundações e se a elaboração do mapeamento se faz necessária. É também nesta etapa que se identificam as prioridades para o início de cada projeto, com base nas necessidades levantadas;

- Escopo do projeto: esta fase implica na contextualização do problema e sensibilização da comunidade, identificação dos dados existentes que podem ser aproveitados e da necessidade de aquisição de novas informações, 
estabelecimento de níveis de prioridade para fontes de inundação a serem analisadas e mapeadas, determinação da abrangência (municipal, regional, etc.) e do meio a ser produzido (digital ou manual); elaboração de cronogramas de desenvolvimento e estimativas de custos para o projeto e atribuição de tarefas a entidades parceiras;

- Desenvolvimento de dados topográficos e de zonas inundáveis / Produção de mapas e relatórios: nesta fase são obtidas ou desenvolvidas as informações topográficas e relativas à batimetria das seções dos rios, necessárias à análise e à delimitação da mancha, também realizadas nesta etapa. As informações produzidas são mescladas com as informações já existentes que não sofreram alterações e são ainda produzidos relatórios, contendo informações e tabelas de dados utilizados;

- Processamento preliminar e pós-preliminar: após a distribuição dos resultados chamados "preliminares", os órgãos públicos, a sociedade e outras entidades interessadas têm a oportunidade de comentar sobre os mapas e relatórios produzidos, através de meios formais e informais. No caso de contribuições ou protestos pertinentes, os produtos são revistos e uma versão "preliminar revisada" dos mapas e relatórios é produzida. Ainda durante o processo pós-preliminar, inicia-se o período de complacência (geralmente seis meses), durante o qual as regiões afetadas sofrem as alterações necessárias em seus regulamentos de gestão de várzeas. É também realizado o controle de qualidade dos produtos, para garantir a precisão das informações apresentadas e sua conformidade com as diretrizes da Agência e também a impressão e distribuição dos mapas e relatórios.

De acordo com a FEMA (2009), a análise de inundações ribeirinhas em si é composta por duas etapas: (i) análise hidrológica, para determinar a probabilidade de ocorrência dos eventos e (ii) análise hidráulica, para determinar a extensão da mancha de inundação e os níveis d'água associados a cada evento. Há vários métodos e programas disponíveis para a análise e representação de áreas inundáveis através de modelagem computacional. A Agência mantém em sua página da internet uma lista com os modelos numéricos - costeiros, hidráulicos, hidrológicos e estatísticos - que cumprem os requisitos mínimos exigidos para o Programa Nacional de Seguro Contra Inundações (FEMA, 2010). Vale ressaltar ainda que, de acordo com avaliação realizada pela FEMA, o fator mais importante 
que influencia a precisão do mapa de inundação é a qualidade dos dados da superfície do terreno (NRC, 2009).

Até 2003, no entanto, a FEMA havia mapeado as áreas de inundação para apenas 1,6 milhões de quilômetros de trechos de rios e costas, de um total de aproximadamente 5,6 milhões de quilômetros de trechos no país. Entre 2003 e 2008, o governo federal investiu um bilhão de dólares em um programa para modernizar o sistema de mapeamento, coletando dados em áreas ainda deficientes no mapeamento e atualizando ou validando mapeamentos já existentes, além de digitalizar os produtos gerados. Mesmo em áreas de inundação mapeadas com alta precisão, o desenvolvimento da sociedade e as mudanças naturais da paisagem e dos sistemas hidrológicos implicam a necessidade de revisões e atualizações contínuas do processo de mapeamento. Os investimentos, porém, não foram suficientes para produzir mapas de alta qualidade para todo o território, sendo que, ao final do programa, apenas $21 \%$ da população era dotada de informações que atendessem aos padrões nacionais de qualidade (NRC, 2009).

De modo a sugerir métodos e abordagens disponíveis para mapeamento de inundações, a Comissão Europeia publicou o Manual de Boas Práticas no Mapeamento de Inundações (EXCIMAP, 2007), elencando práticas adotadas na Europa. A publicação divide o mapeamento em três categorias: mapa de inundação ("flood plain map"), mapa de vulnerabilidade ("flood hazard map") e mapa de risco ("flood risk map"). O primeiro termo associa-se somente à identificação da probabilidade de ocorrência da inundação e sua abrangência, enquanto os dois últimos apresentam informações adicionais a estas áreas definidas. Por exemplo, um mapeamento da vulnerabilidade pode conter ainda a profundidade da lâmina d'água e a velocidade e direção do fluxo; já um mapeamento do risco deve indicar os potenciais impactos negativos associados às inundações, expressos em termos, por exemplo, de número de habitantes afetados, atividades econômicas potencialmente atingidas, instalações que possam causar poluição acidental, etc.

De acordo com o Manual, os mapas de inundação, que apresentam as possíveis áreas inundadas, são normalmente bastante genéricos, sem apresentar informações mais detalhadas, como profundidade da água, por exemplo, a fim de facilitar sua compreensão. Este tipo de mapeamento é o instrumento mais amplamente distribuído na Europa sendo que, de acordo com um levantamento realizado, em 2006, com 19 países e organizações europeias, a grande maioria afirmou adotar tal 
ferramenta, muitas vezes realizada para subsidiar um processo legal, como construções à prova de enchentes e ordenamento territorial. Em relação à metodologia utilizada, a pesquisa revelou unanimidade: análise hidrológica e modelagem hidráulica, subsidiada por modelos digitais de terreno de alta precisão e calibração através de dados históricos.

A publicação conta ainda com um Atlas, que fornece exemplos de mapas de inundações disponíveis em 19 países europeus, além dos Estados Unidos e Japão.

No Japão, devido à topografia acidentada e ao histórico de ocupação, as inundações fazem parte dos desastres naturais mais comuns. Além das medidas tradicionais, como construção de barragens e diques, novas medidas - estruturais e não estruturais - têm sido gradualmente implementadas, sendo o mapeamento da vulnerabilidade às inundações ("flood hazard map") umas das mais importantes ferramentas. Em 1994, o Ministério da Construção passou a incentivar, através de suporte técnico e financeiro, os governos municipais à publicação desse tipo de mapa, que deve ser distribuído a toda a população. Esses mapas de vulnerabilidade baseiam-se em mapas de áreas de inundação divulgados anteriormente pelo Ministério, com algumas informações atualizadas e detalhadas, e seu objetivo é auxiliar no plano de evacuação local. Essa ferramenta tem se mostrado bastante efetiva, desempenhando um importante papel nos sistemas tradicionais de combate às inundações, especialmente em municípios de pequeno porte. Apesar da aceitação pública deste tipo de medida, algumas autoridades municipais ainda hesitam em aplicá-la, com medo de protestos e desequilíbrio no mercado imobiliário (SHIDAWARA, 1999).

No Brasil, conforme já mencionado, as ações que visam o controle de inundações ocorrem de forma isolada (TUCCl; BERTONI, 2003). A seguir, são apresentados alguns exemplos de mapeamento realizados no país.

Vale do Itajaí

Tucci (2009) apresenta como exemplo de mapeamento preliminar o estudo realizado nas cidades do Vale do Itajaí. O procedimento simples baseou-se em 
mapas topográficos de níveis de qualidade variados, sendo que, para as áreas mais propensas a inundações, sugere-se a elaboração de mapas mais detalhados.

Para as cidades com dados, foi determinada a curva de probabilidade de vazões, com períodos de retorno de 5, 25, 50 e 100 anos, e as cotas foram obtidas através da curva-chave, considerando ainda os desníveis das declividades das maiores enchentes, com base nas marcas das enchentes encontradas pelas cidades.

\section{Bacia do Córrego do Bananal, São Paulo - SP}

Com o objetivo de se delimitar as planícies de inundação da bacia do córrego do Bananal com maior precisão, para o Plano de Bacia Urbana (BARROS et al., 2005) adotou-se o Sistema de Suporte à Decisão desenvolvido para a bacia do rio Cabuçu de Baixo (BARROS et al., 2004), no qual foram empregados modelos de simulação hidrológica e hidráulica desenvolvidos pela Fundação Centro Tecnológico de Hidráulica (FCTH), a saber: CAbc - Simulador Hidrológico de Bacias Complexas e CLiv - Condutos Livres, respectivamente. O primeiro é um modelo matemático para determinação de chuvas excedentes e hidrogramas de escoamento superficial, que vem sendo amplamente utilizado no gerenciamento de recursos hídricos por todo o país. A aplicação do CAbc possibilitou estimar a contribuição do escoamento superficial da bacia, através das curvas chuva-vazão, para a então aplicação do modelo hidrodinâmico CLiv, para determinação de áreas de inundação. Através dessa segunda etapa de modelagem, com base nas características da seção de escoamento, foram determinadas as curvas cota-vazão; ou seja, foram estimados os níveis de água em caso de chuvas intensas para diferentes períodos de retorno (2, $5,10,25$ e 50 anos) e, relacionando-os à topografia da bacia, foi possível estabelecer os limites das áreas inundáveis (BARROS et al., 2005). É bastante válido ressaltar que os parâmetros adotados em ambas as modelagens foram alvo de calibração com base dados medidos em eventos observados. 
Carta de inundações, Belo Horizonte - MG

A prefeitura municipal de Belo Horizonte disponibiliza em sua página da internet a base cartográfica com a delimitação de manchas de inundação, como consequência da implementação dos conceitos e diretrizes do Plano Diretor de Drenagem Urbana do município. O projeto, entitulado Carta de Inundações de Belo Horizonte Identificação de Áreas Potencialmente Suscetíveis aponta 82 manchas de inundação espalhadas entre as nove regiões administrativas do município.

Foram elaborados estudos de modelagem matemática hidrológica e hidráulica para períodos de retorno de 2, 5, 10, 15, 20, 25, 50 e 100 anos, identificando-se trechos críticos de ocorrência de inundação e mapeando as áreas inundadas para os períodos de 25 e 100 anos de recorrência. As alturas de níveis d'água obtidas para diferentes trechos e os limites das áreas de inundação foram resultados da modelagem matemática associada à pesquisa de campo. (BELO HORIZONTE, 2009).

Os modelos aplicados também foram aqueles desenvolvidos pela Fundação Centro Tecnológico de Hidráulica - CAbc e CLiv (COBRAPE, 2010), já citados anteriormente. A base de dados georreferenciada, contendo elementos de macrodrenagem, curvas de nível e arruamento, foi manipulada no AutoCAD.

Para os trechos de canais revestidos, foi possível ainda associar o início do extravasamento às alturas pluviométricas, atribuindo-se a cada trecho um nível de criticidade de acordo com o período de retorno das chuvas (BELO HORIZONTE, 2009).

\subsubsection{Zoneamento das áreas de risco e definição da ocupação}

O zoneamento das áreas inundáveis corresponde a uma etapa posterior ao mapeamento e consiste no estabelecimento de regras para a ocupação das áreas de acordo com o risco de inundação, visando à redução de prejuízos decorrentes das chuvas intensas (TUCCI, 2009). As regulamentações de ocupação restringem o desenvolvimento em áreas de risco a usos que não sofreriam perdas extensas 
devido às enchentes e podem, ainda, incentivar o crescimento urbano em locais seguros, por meio de detalhamentos quanto à localização, tipo, quantidade, densidade e características do desenvolvimento permitido nos distritos de zoneamento mapeados (SCHWAB, 2010).

Independente da metodologia aplicada, o mapeamento das áreas inundáveis deve ser capaz de distinguir faixas, transversais à seção de escoamento, referentes ao risco de inundação, como pode ser observado na Figura 3. Neste exemplo, a Faixa 1 representa a zona de passagem de enchentes, ou seja, corresponde ao leito menor do rio, a Faixa 2 (zonas com restrições) equivale à planície de inundação (leito maior) e pode estar subdividida em função dos períodos de retorno das inundações, enquanto a Faixa 3 representa as áreas que não devem ser atingidas quando da ocorrência de vazões com período de recorrência de 100 anos (zona de baixo risco) (TUCCI, 2009).

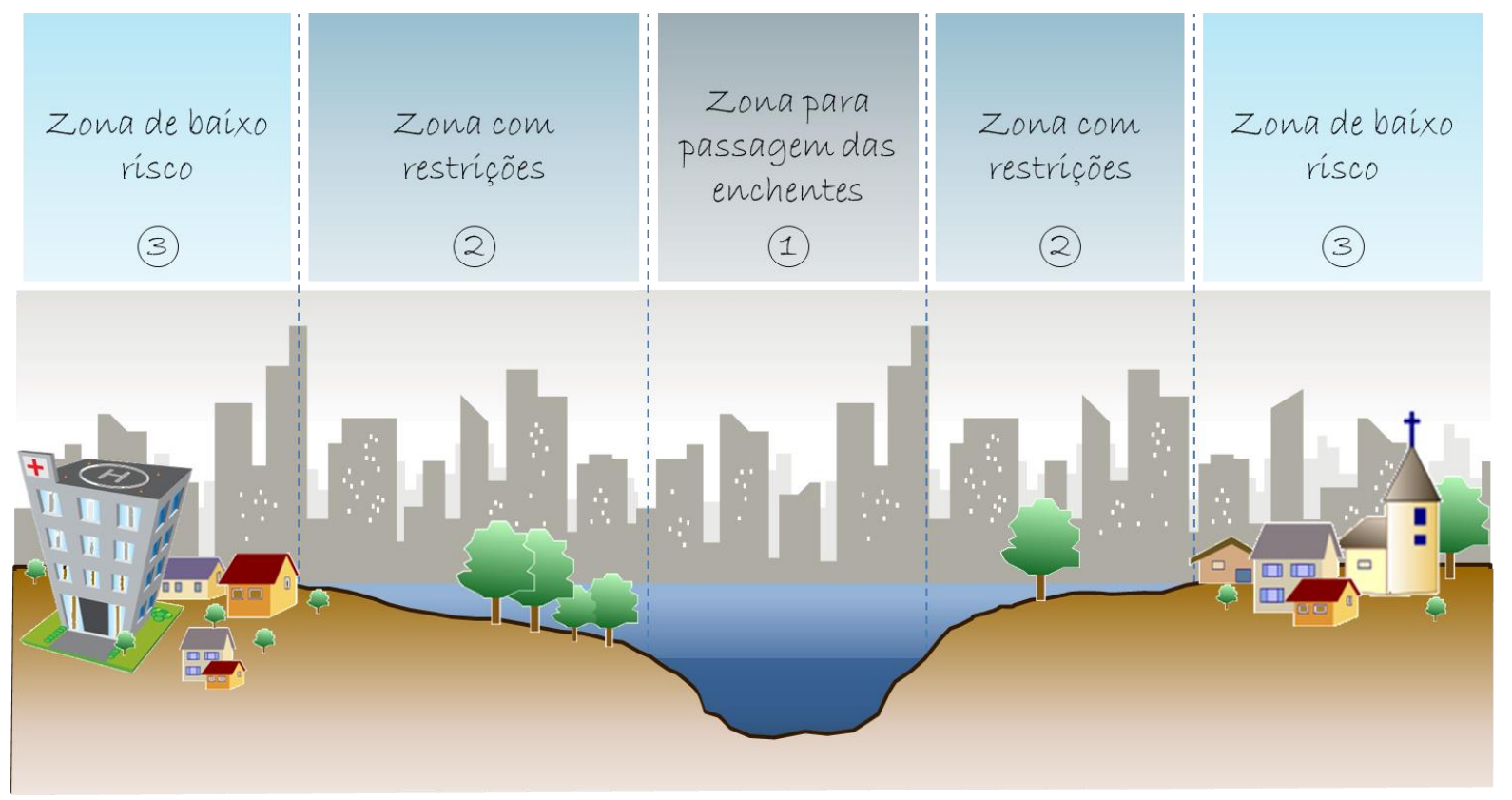

Figura 3 - Zoneamento de áreas inundáveis.

A proposição de regulamentações para o uso do solo é dificultada devido ao fato de não haver critérios comuns para a ocupação de áreas sujeitas a inundações (EXCIMAP, 2007). As regulamentações mais comuns proíbem o desenvolvimento dentro do leito menor, onde obstruções limitariam sua capacidade, aumentando a ocorrência de inundações a jusante, e também restringem o desenvolvimento no leito maior (SCHWAB, 2010). A seguir, são apresentados exemplos gerais de 
diretrizes de ocupação para a planície de inundação, com base nas zonas apresentadas na Figura 3:

- Zona para passagem das enchentes (faixa 1): com o intuito de se manter essa faixa desobstruída, não devem ser permitidas novas construções nesta área, salvo raras exceções, onde as obras devem estar estruturalmente protegidas contra inundações. No caso de obras como pontes e rodovias, devem ser estimados os impactos que seriam causados devido a obstruções ao escoamento. São exemplos de usos permitidos nessa zona a agricultura e a instalação de linhas de transmissão e condutos hidráulicos. No caso de construções existentes, devem ser aplicadas medidas de correção, como, por exemplo, na questão habitacional, a realocação de moradias (TUCCI, 2009). Instalações destinadas a lazer e recreação também são convenientes, mediante a criação de parques lineares (SÃO PAULO, 2012);

-Zonas com restrições (faixa 2): os usos permitidos nestas zonas podem variar em função do cenário de risco identificado, mas consistem basicamente em: parques recreativos e áreas de lazer; agricultura; construções habitacionais com padrão construtivo adequado às condições dinâmicas das cheias ocorrentes; centros industriais e comerciais estruturados de forma a não sofrer prejuízos de cheia ou causar transtornos ambientais, como no caso do armazenamento de produtos tóxicos; e linhas de transmissão, rodovias e pontes, desde que corretamente projetados (TUCCI, 2009); e

-Zona de baixo risco (faixa 3): nesta área, podem ser descartadas medidas individuais de proteção para as construções, mas recomenda-se a instrução da população em relação aos meios de proteger-se das perdas decorrentes de eventuais inundações (TUCCI, 2009).

Em meio às diretrizes apresentadas, vale ressaltar que é possível a alocação de moradias nas zonas com restrições, desde que com precauções especiais, que constituem os critérios para uma construção à prova de enchente. Tucci e Bertoni (2003) definem a construção à prova de enchente como o "conjunto de medidas projetadas para reduzir as perdas dos prédios localizados nas várzeas de inundação durante a ocorrência das cheias". Dentre as medidas que compõem este conjunto, os autores citam:

- o estabelecimento de, pelo menos, um piso com nível superior à linha d’água estimada; 
- a vedação (temporária ou permanente) das aberturas como portas, janelas e dispositivos de ventilação;

- a elevação de estruturas existentes;

- a construção de novas estruturas sobre pilotis;

- a construção de pequenos diques circundando as estruturas;

- a realocação ou proteção individual de artigos que possam ser danificados;

- a realocação de equipamentos elétricos;

- a estanqueidade e reforço das paredes de porões; e

- o uso de material resistente à submersão ou contato com a água.

A Figura 4 apresenta exemplos de ocupação nas zonas definidas de acordo com o risco de inundação.

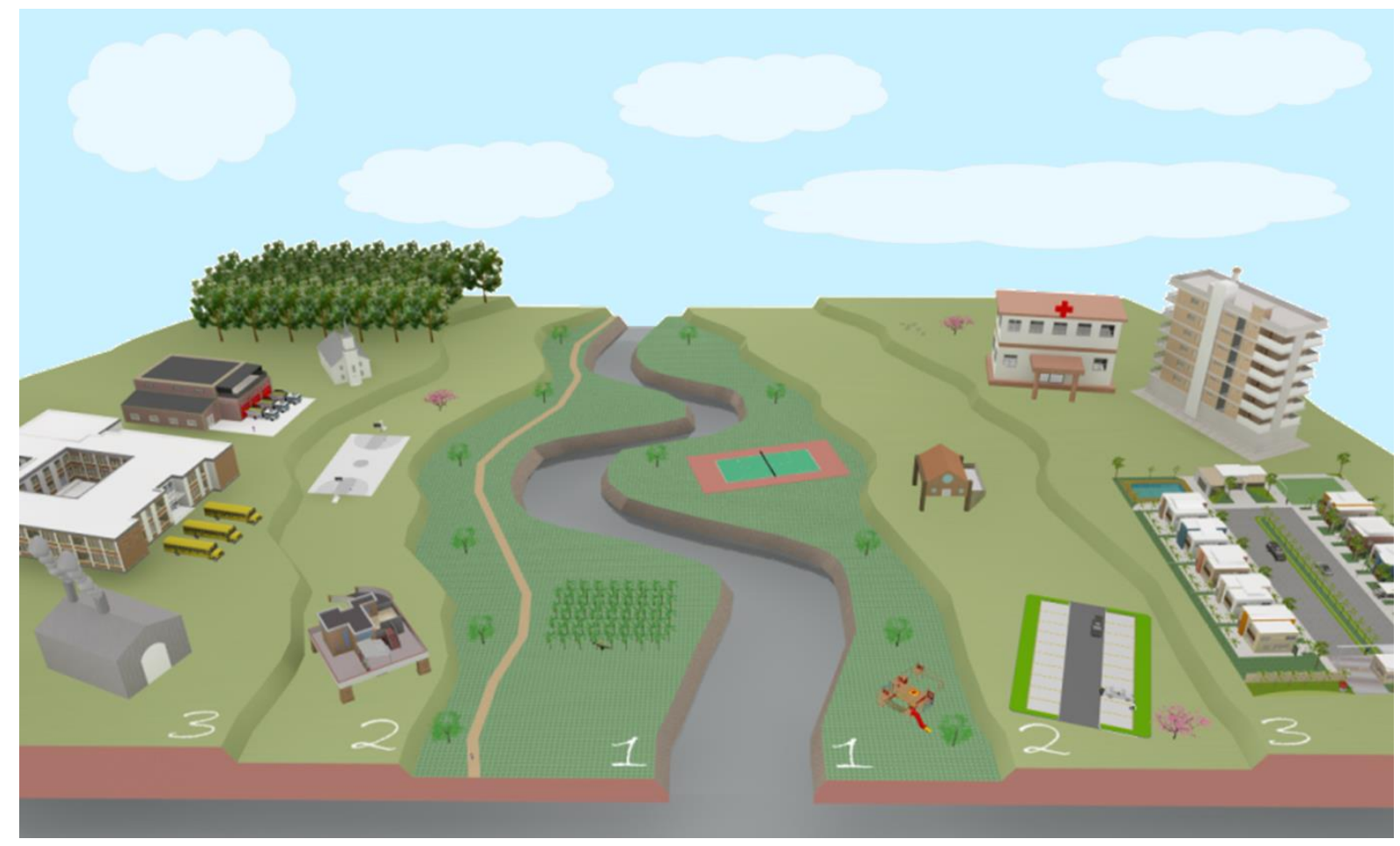

Figura 4 - Sugestão de ocupação compatível com o zoneamento de áreas inundáveis.

De acordo com Schwab (2010), o zoneamento está entre as ferramentas mais eficazes de planejamento para reduzir os riscos às inundações. Esta ferramenta tem a capacidade de limitar o desenvolvimento em áreas de risco a usos que não sofreriam perdas extensas quando da ocorrência de desastres, incentivando o crescimento das cidades em locais seguros. Para isso, deve ser especificada a localização, tipo, quantidade, densidade e características do desenvolvimento permitidos nos distritos de zoneamento mapeados. $\mathrm{O}$ autor cita como exemplo as 
regulamentações aplicadas na cidade de Chapel Hill, localizada na Carolina do Norte, EUA:

- Na zona para passagem das enchentes, é permitida a ocupação para fins de:

- Usos agrícolas, parques, áreas verdes e outros equipamentos de recreação semelhantes, públicos ou privados, que não requeiram fertilizantes, pesticidas, cercas ou muros extensos;

- Calçadas de passeio;

- Linhas de serviço de utilidade pública, quando comprovada necessidade prática;

- Atividades de manutenção pública de ruas, pontes, outros meios de transporte similares e /ou de utilidade pública e instalações de drenagem de águas pluviais e restauração de áreas ribeirinhas;

- Os seguintes usos, no entanto, são permitidos apenas a partir da zona com restrições:

- Pastagens, viveiros de plantas, jardins e áreas de lazer que não necessitem de pesticidas;

- Campos para prática de arco e flecha, estruturas de piquenique e playground e outros equipamentos de recreação semelhantes, públicos ou privados, que não requeiram fertilizantes, pesticidas, cercas ou muros extensos;

- Atividades paralelas normalmente associadas a habitações de uma ou duas famílias, tais como cercas, jardins e usos semelhantes;

- Detenção / retenção de bacia e infraestruturas associadas;

- Atividades que possam demandar fertilizantes ou pesticidas, como, por exemplo, gramados, campos de golfe e outros jogos similares, são permitidas apenas na zona de baixo risco;

- Ruas, pontes e outros meios de transporte similares, lagos, lagoas, e infraestruturas associadas, tais como barragens, vertedouros, etc., só devem ser instalados mediante permissão especial, concedida pela prefeitura, seja qual for a zona objeto de intervenção;

O município de Fort Collins, localizado no estado do Colorado, é outro exemplo norte-americano considerado com regulamentações bem definidas para as áreas de inundação. Além das diretrizes formais, o município dispõe de um guia bastante didático, que exemplifica os critérios para a bacia do rio Poudre. O guia segmenta os 
possíveis desenvolvimentos em três tipos: residenciais, não residenciais e mistos. As permissões são classificadas de acordo com as zonas:

- No caso da zona para passagem das enchentes, não são permitidos:

- novos empreendimentos, reconstruções ou ampliações de qualquer tipo;

- garagens avulsas e alpendres;

- construções de novos porões (no caso de construções residenciais, os porões existentes devem ser suprimidos $e$, no caso de usos nãoresidenciais, porões existentes podem permanecer, desde que atendem critérios de construções à prova de enchentes);

- novas construções para o depósito e armazenamento de equipamentos e materiais;

- Ainda no caso da zona para passagem das enchentes:

○ aterramentos são permitidos, desde que não impliquem em elevação do nível d'água;

- reformas são permitidas apenas mediante o atendimento de critérios rigorosos e devem requerer concessões especiais;

- casas pré-fabricadas e escritórios modulares são permitidos apenas em loteamentos existentes para estas finalidades;

- No caso das zonas com restrições:

○ aterramentos são permitidos;

- novas construções e ampliações são permitidas apenas para usos nãoresidenciais, desde que atendam a critérios específicos;

- reformas e reconstruções são permitidas mediante o atendimento a critérios específicos;

- casas pré-fabricadas e escritórios modulares são permitidos apenas para substituir ou ocupar lotes vagos em loteamentos existentes para estas finalidades;

- novos porões são permitidos apenas para usos não-residenciais, desde que atendam a critérios específicos (no caso de construções residenciais, os porões existentes devem ser suprimidos e, no caso de usos nãoresidenciais, porões existentes podem permanecer, desde que atendem critérios de construções à prova de enchentes);

- garagens avulsas e alpendres são permitidos. Para empreendimentos residenciais, garagens incorporadas não são permitidas; 
- novas construções para o depósito e armazenamento de equipamentos e materiais flutuantes não são permitidas;

- Instalações críticas, como postos de saúde, escolas, estações de polícia ou bombeiro, postos de gasolina e depósitos de materiais perigosos, são proibidas em ambas as zonas (FORT COLLINS, 2010).

King (2010) estima que, nos Estados Unidos, cerca de 1,2 bilhão de dólares em prejuízos seja evitado anualmente em decorrência dos critérios de gestão de várzea adotados como requisito ao Programa Nacional de Seguro Contra Inundações, responsável por tornar o zoneamento um instrumento bastante difundido no país.

No Brasil, um exemplo de aplicação do zoneamento consiste em uma das ações propostas para a bacia do córrego do Bananal, que seria a implantação de um parque linear nas áreas de inundação do córrego, que serão objeto de estudo de realocação de moradias e comércio. A área do parque proposto, situada em uma zona classificada como zona com restrições, foi dividida em dois setores (BARROS et al., 2005):

- Setor 1: áreas inundáveis com período de retorno de 25 anos, considerando, ainda, largura mínima de 10 metros para cada margem. O único uso será a recuperação da vegetação ripária ou ciliar para restabelecimento de suas funções hidrológicas e ecológicas; e

- Setor 2: porção não alagada das áreas marginais ao córrego para o período de retorno de 25 anos. Essa zona deverá alocar espaços de atividades recreativas e esportivas, como ciclovias, pistas de corrida e quadras.

O devido gerenciamento de áreas de risco de inundação no Brasil, no entanto, ainda está muito aquém das necessidades das bacias urbanas brasileiras. Há ainda muito a avançar em termos de políticas de gerenciamento de riscos, sendo a integração de fatores ambientais fundamental no planejamento do uso do solo. As regulamentações do uso do solo em função da possibilidade de ocorrência de enchentes e inundações envolvem definição da ocupação das áreas de risco na várzea e devem estar contidas no Plano Diretor de cada município (TUCCI, 2006).

Müller (2011) lembra que a legislação relativa ao uso e ocupação do solo no país provém das três esferas administrativas (federal, estadual e municipal) e analisa a complexidade da relação entre as leis. $O$ autor apresenta um levantamento da legislação pertinente para analisar a aplicabilidade de medidas não estruturais no município de Joinville - SC. A Secretaria Municipal de Desenvolvimento Urbano de 
São Paulo (SÃO PAULO, 2012) fornece a fundamentação legal aplicável ao município de São Paulo - SP, relativa à elaboração e aplicação de um plano de drenagem. Tucci e Bertoni (2003) também apresentam uma análise das legislações que envolvem as águas urbanas dentro do cenário brasileiro.

Entre as estratégias e ações propostas na Agenda 21 Brasileira, destaca-se a primeira estratégia proposta no âmbito da gestão dos recursos naturais, que visa regular o uso e a ocupação do solo através de métodos de planejamento ambiental, incluindo as diversas formas de zoneamento, e a articulação de unidades espaciais relevantes para a conservação dos recursos naturais, como corredores ecológicos, unidades de conservação, ecossistemas terrestres, costeiros e marinhos e as bacias hidrográficas. Para isso, o documento sugere o estabelecimento de meios de apoio à elaboração e implementação de tais zoneamentos ambientais, através de instrumentos técnicos e políticos para o planejamento do desenvolvimento sustentável nas regiões brasileiras, com transparência de métodos e discussão de resultados e, com isso, espera-se que seja possível priorizar políticas públicas coerentes com os princípios de sustentabilidade socioeconômica e ambiental (BRASIL, 2004)

O artigo 30 da Constituição Federal define como competência municipal o planejamento e controle do uso e ocupação do solo urbano. As regulamentações do uso do solo devem estar contidas no Plano Diretor de cada município, que está previsto pelo parágrafo $1^{\circ}$ do artigo 182 da Constituição e é regulamentado pelo Estatuto das Cidades, instituído pela Lei Federal №. 10.257/2001. Nesse contexto, Braga (2003) afirma que é fundamental que as leis de zoneamento urbano devam incorporar diretrizes de proteção ambiental e controle da ocupação das regiões de cabeceiras, fundos de vale, planícies de inundação e áreas de alta declividade, além de visar o aumento da permeabilidade do solo. As diretrizes de uso e ocupação do solo constantes do Plano Diretor devem também estar articuladas com políticas públicas de recursos hídricos, licenciamento ambiental, resíduos sólidos, educação ambiental e habitação, sendo observadas, ainda, as competências das esferas estaduais e federal.

De acordo com a Fundação Seade (2011), dos 645 municípios paulistas, apenas 149 (23\%) possuíam lei de Plano Diretor aprovada em 2003. Ainda assim, muitos destes documentos não enfatizam a temática ambiental, focando exclusivamente aspectos arquitetônicos e urbanísticos, o que demonstra o déficit de políticas 
públicas articuladas com o planejamento ambiental integrado dos setores urbanos (CRUZ; SOUZA; TUCCI, 2007).

Apesar de o zoneamento urbano, de forma geral, ser um instrumento urbanístico bastante difundido, Braga (2001) discute que é também um mecanismo de gestão muito criticado, devido à sua eventual ineficácia e efeitos perversos, como especulação imobiliária e segregação socioespacial.

A interface entre a política de recursos hídricos e as políticas de transporte e habitação também deve ser analisada, uma vez que, de acordo com Silva e Porto (2003), estes últimos setores são determinantes nos processos de uso e ocupação do solo e, portanto, interferem sobre a preservação de áreas de mananciais e zonas de restrição de vazão de enchente, mas não estão diretamente relacionados às competências da gestão de bacias.

Tucci (1999) destaca Estrela, no Rio Grande do Sul, como uma experiência bem sucedida. O município teve a legislação de zonas de uso especial implementada dentro de seu Plano Diretor, sendo definidas restrições de ocupação e construções abaixo de determinadas cotas, estabelecidas no zoneamento de inundação. $\mathrm{O}$ artigo 26 da lei que institui o Plano Diretor de Desenvolvimento Integrado do Município (ESTRELA, 2006) define:

$\S 3^{\circ}$ Nas áreas inundáveis, somente serão permitidas construções novas em terrenos aterrados até a cota 26 (vinte e seis metros), respeitando as diretrizes do Código do Meio Ambiente do Município.

$\S 4^{\circ}$ As construções existentes nas áreas inundáveis, enquadradas nas atividades permitidas ou permissíveis, somente poderão efetuar melhorias, reformas ou reconstruções, desde que estejam acima da cota $24 \mathrm{~m}$ (vinte e quatro metros) e estas serão sobre pilotis, permitida a TO (taxa de ocupação) de 30\% (trinta por cento) no nível térreo, permanecendo o restante da área aberta ou coberta, elevando-se acima da cota $26 \mathrm{~m}$ (vinte e seis metros).

A legislação municipal de Estrela também prevê, por lei, trocas de área de inundação por índice de ocupação em zonas valorizadas, de modo a concentrar áreas de risco para uso público (TUCCI, 1999).

Tucci e Bertoni (2003) sugerem exemplos de artigos que podem ser incluídos na legislação municipal para regulamentar o uso de áreas ribeirinhas. Os autores adotaram como base legislações de zoneamento existentes, complementando-as através do zoneamento de áreas de risco de inundação:

Artigo $3^{\circ}$ Para o efeito de aplicação da presente lei, são adotadas as seguintes definições:

[...] Parágrafo $4^{\circ}$ - Dos termos gerais

[...] I) área de risco de inundação: é a área com cota igual ou inferior a cota (a definir), denominado aqui de NM. 
Art. 9o A permissão para a localização de qualquer atividade considerada como perigosa, nociva ou incômoda, dependerá da aprovação do projeto completo, se for o caso, pelos órgãos competentes da União, do Estado e Município, além das exigências especificas de cada caso. Parágrafo Único: [...]

[...] g) armazenagem ou processamento, nas áreas de risco de inundação, de material que misturado com a água seja prejudicial a saúde humana.

Art. 11 Para a instalação de obra ou atividade, potencialmente geradora de grandes modificações no espaço urbano, poderá ser exigido o Relatório de Impacto de Vizinhança, no seguinte caso:

I - edificações com área computável, para cálculo do coeficiente de aproveitamento, superior a $10.000 \mathrm{~m}^{2}$ (dez mil metros quadrados).

[...] Parágrafo 4ํำ No projeto de urbanização da área mencionada em I, a vazão máxima de saída da drenagem pluvial, deverá ser menor ou igual a vazão proveniente dessa área, antes da urbanização.

Art 14을 Fica determinada a Zona Central como correspondente à área central e seu entorno, definida pelos níveis da cota de enchente da cheia NM.

Art 15을 Fica determinada a Zona de Baixa Densidade como correspondente à área situada entre as cotas de enchente (a definir) $\mathrm{m}$ e (a definir) $\mathrm{m}$.

Parágrafo Único - Para esta zona, ficam estabelecidos os seguintes objetivos e instrumentos:

[...] g) retirar o imposto para os imóveis com os seguintes usos: agrícola, parques ou praças privados; áreas esportivas; estacionamento; áreas de carregamento; áreas de armazenamento de material facilmente removível ou não sujeitos a danos de enchentes.

[Inserir um artigo depois do art. 22, denominado aqui de art. 22']

Art 22' Todos os projetos de construções localizadas nas áreas de risco de inundação devem ser fiscalizados quanto ao seguinte:

a. estabelecimento de, pelo menos, um piso com nível superior a NM (cota da cheia máxima);

b. uso de materiais resistentes à submersão ou contato com a água;

c. equipamentos elétricos em cota acima da cota NM. Prever o desligamento do sistema de alimentação durante o período de cheia;

d. proteção dos aterros contra erosões;

e. prever os efeitos das enchentes nos projetos de esgotos pluvial e cloacal;

f. estruturalmente, as construções devem ser projetadas para resistir a: (i) pressão hidrostática, que pode causar problemas de vazamento; (ii) empuxos e momentos; (iii) erosão.

g. fechamento de aberturas como portas, janelas e dispositivos de ventilação quando

h. é desejado proteger o piso submetido a inundação;

i. estanqueidade e reforço das paredes de porões e pisos sujeito a inundação;

j. ancoragem de paredes contra deslizamentos;

k. para os pisos previstos que inundem, prever o escoamento através da obra, evitando o desmoronamento de paredes;

I. prever o transporte de material de valor para pisos superiores e a habitação por até três meses nos pisos superiores (TUCCI; BERTONI, 2003).

No caso de áreas consolidadas, deve ser analisada a vulnerabilidade de cada região, como forma de priorizar as medidas de controle. Goerl; Kobiyama e Pellerin (2012) estimam o risco das inundações para o município de Rio Negrinho - SC, relacionando a área inundada em cada setor censitário a um índice de vulnerabilidade, que leva em conta informações obtidas do recenseamento demográfico, como o número de moradores, a densidade demográfica, a distribuição das faixas etárias, o número de pessoas analfabetas e a parcela da população com baixo ou nenhum rendimento mínimo. 


\section{METODOLOGIA}

A metodologia utilizada no presente estudo será aplicada na zona urbana do município de Atibaia, que está localizado na Serra da Mantiqueira, a sudoeste do Estado de São Paulo, a $67 \mathrm{~km}$ da capital paulista, e faz divisa com os municípios de Bom Jesus dos Perdões, Bragança Paulista, Campo Limpo Paulista, Francisco Morato, Franco da Rocha, Jarinu, Mairiporã, Nazaré Paulista e Piracaia.

A maior parte do município situa-se na bacia do rio Atibaia, o qual atravessa o município imediatamente após sua formação, dada pela confluência dos rios Atibainha e Cachoeira, a jusante de importantes reservatórios que compõem o sistema Cantareira.

Os principais acessos à cidade são as Rodovias Dom Pedro I (SP-065), que liga Campinas a Jacareí, e Fernão Dias (BR-381), que liga São Paulo a Belo Horizonte (ATIBAIA, 2011).

A Figura 5 ilustra a localização do município. 


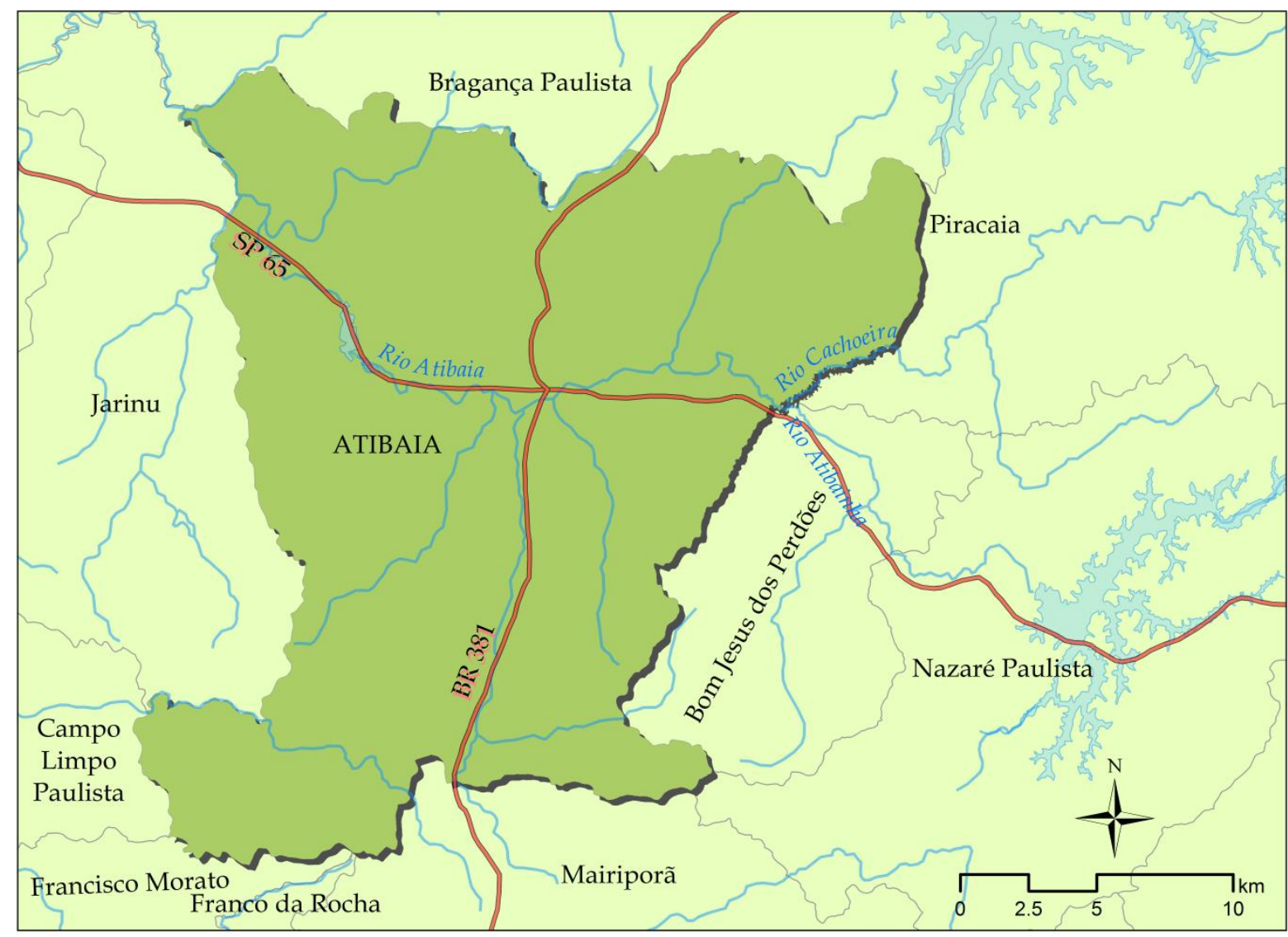

\section{Legenda}

Limites municipais

Rodovias principais

Hidrografia principal

Represas principais

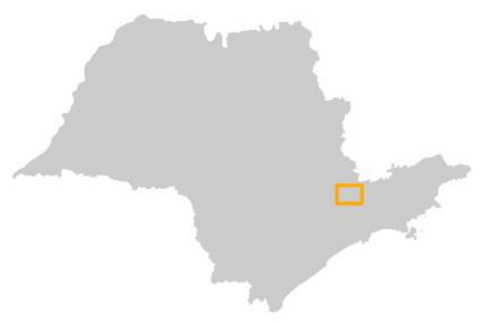

Figura 5 - Localização da área de estudo.

A ocupação das várzeas do rio Atibaia, mais intensificada a partir da década de 1990, surge como importante fator de agravamento das consequências das enchentes na região (DAEE, 2011b). Os eventos de chuva ocorridos no verão 2009/2010 e novamente no verão 2010/2011 provocaram grandes inundações na bacia do rio Atibaia. A Figura 6 apresenta algumas imagens registradas após as fortes chuvas de janeiro de 2011, em diferentes bairros da cidade, o que evidencia a abrangência dos impactos relacionados às cheias. Eventos como este tendem a ser tornar cada vez mais frequentes à medida que se aumenta a impermeabilização do solo e seus impactos tendem a ser cada vez mais extremos devido à ocupação humana das regiões de várzea. Os valores registrados em ambos os períodos foram foco de análise e discussão. Os eventos mais críticos ocorridos entre os anos de 
2009 e 2011 serviram também como base para a calibração da modelagem hidráulica.

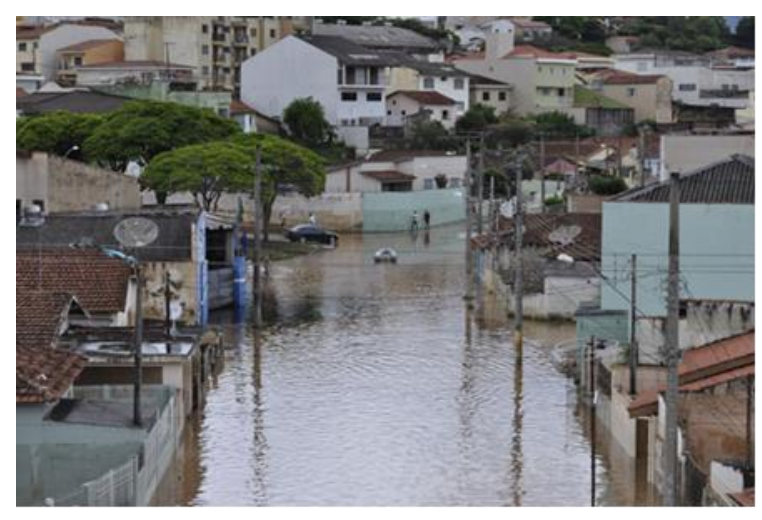

Jardim Brasíl

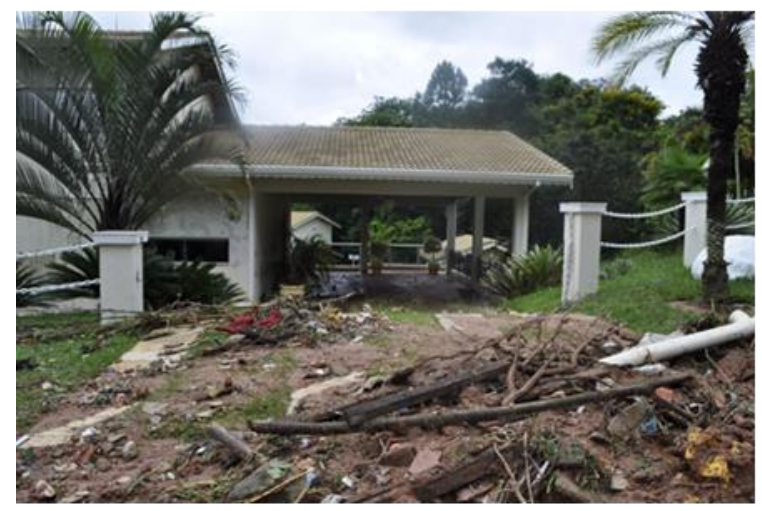

Regíão Flamboyant

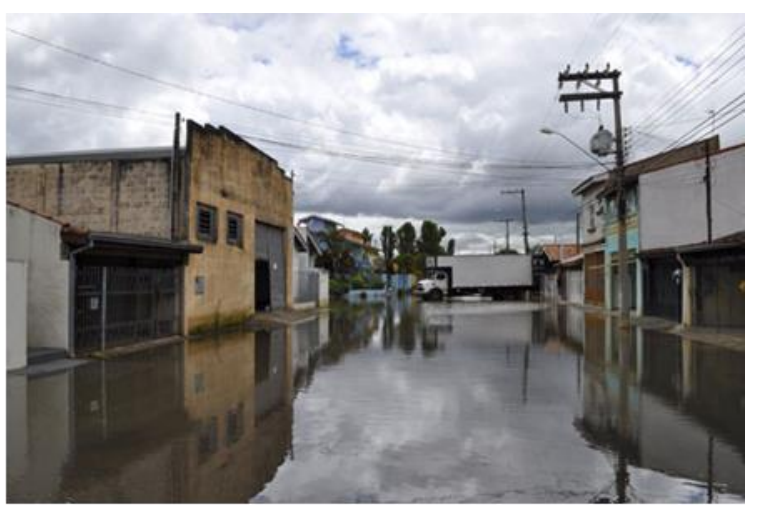

Parque das Nações

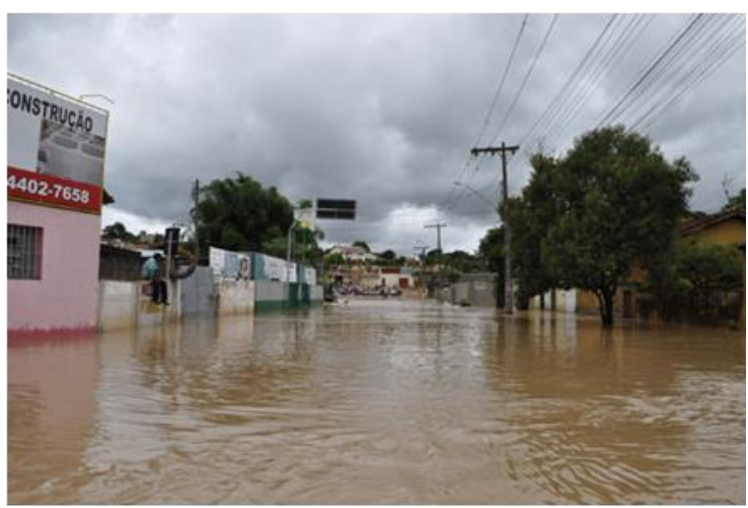

caetetuba

Figura 6 - Imagens das enchentes ocorridas em janeiro de 2011 no município de Atibaia (KONIG, 2011).

A metodologia adotada está agrupada em dois conjuntos: (i) mapeamento das áreas de inundação, com base no risco de ocorrência das cheias, e (ii) análise do uso e ocupação do solo, resultando na proposição de medidas de intervenção para o planejamento da ocupação urbana em áreas de várzea.

\subsection{Mapeamento das áreas inundáveis}

A metodologia de mapeamento das áreas de inundação do rio Atibaia no município de Atibaia segue a lógica sugerida pela FEMA (2009) e é composta por duas etapas: (i) análise hidrológica, para determinar a probabilidade de ocorrência 
dos eventos e (ii) análise hidráulica, para determinar a extensão da mancha de inundação e os níveis d'água associados a cada evento. O fluxograma apresentado na Figura 7 resume as informações e ferramentas necessárias para esta etapa.

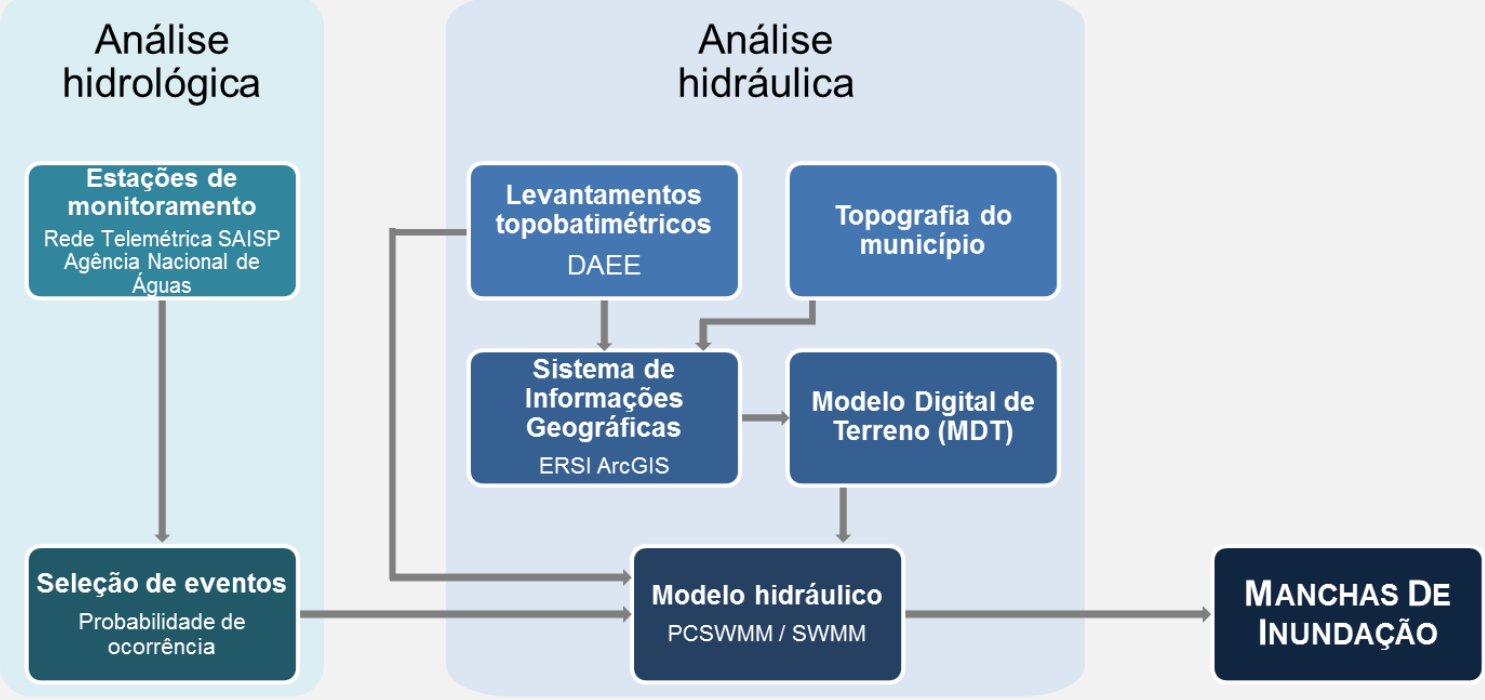

Figura 7 - Fluxograma das etapas do mapeamento das áreas inundáveis.

\subsubsection{Análise hidrológica}

A fim de se conhecer o comportamento hidrológico da região, foram feitas análises estatísticas das medições de chuva e nível para os postos de medição selecionados. Posteriormente, foram comparados à análise estatística os valores medidos para os eventos extremos ocorridos recentemente.

\subsubsection{Estações de monitoramento}

Os dados de chuva e nível referentes aos mais recentes eventos de cheia ocorridos no município de Atibaia foram obtidos do banco de dados da Rede Telemétrica de Hidrologia do DAEE, através do Sistema de Alerta a Inundações de São Paulo - SAISP (FCTH, 2011). Foram analisados os dados dos postos 53, $54 \mathrm{e}$ 
80, localizados nos rios Cachoeira, Atibaia e Atibainha, respectivamente. A localização destes postos está representada na Figura 9. A escolha estratégica destes postos permite caracterizar a magnitude de tais eventos logo a jusante dos reservatórios do sistema Cantareira e também na região central do município.

A relação das estações pluviométricas e fluviométricas utilizadas, sua localização e data de início do monitoramento estão contidas na Tabela 2.

Tabela 2 - Identificação das estações telemétricas selecionadas.

\begin{tabular}{|c|c|c|c|c|}
\hline Código & NOME DA ESTAÇÃO & MUNICÍPIO & CORPO D'ÁGUA & $\begin{array}{c}\text { INÍCIO DO } \\
\text { MONITORAMENTO }\end{array}$ \\
\hline 53 & $\begin{array}{c}\text { Rio Cachoeira - Captação Piracaia } \\
(\text { (E3-110T/3E-116T) }\end{array}$ & Piracaia & Rio Cachoeira & 09/11/1999 \\
\hline 54 & $\begin{array}{l}\text { Rio Atibaia em Atibaia } \\
\text { (E3-111T / 3E-063T) }\end{array}$ & Atibaia & Rio Atibaia & $01 / 06 / 2000$ \\
\hline 80 & $\begin{array}{l}\text { Rio Atibainha em Nazaré Paulista } \\
\text { (3E-089T) }\end{array}$ & Nazaré Paulista & Rio Atibainha & $14 / 07 / 2001$ \\
\hline
\end{tabular}

Os dados consolidados para cada série pluviométrica foram obtidos do estudo de Previsão de Níveis e Vazões na Bacia do Rio Piracicaba (FCTH, 2012), que realizou o processamento dos dados de chuva para todos os postos da bacia. Após a consolidação dos dados de chuva (desagregação dos valores acumulados e preenchimento de falhas), foi realizada uma avaliação das precipitações acumuladas mensais.

$\mathrm{Na}$ análise feita por FCTH (2012), as séries pluviométricas foram comparadas às curvas IDF para a região de cada posto. Para isso utilizou-se o programa Plúvio 2.1 (2006), que adota a seguinte equação:

$$
I_{m}=\frac{k \cdot T^{a}}{(t+b)^{c}}
$$

Isolando o termo $T$, a fórmula fica:

$$
T=\sqrt[a]{\frac{I_{m} \cdot(t+b)^{c}}{k}}
$$

Onde:

Im = intensidade máxima média de precipitação $(\mathrm{mm} / \mathrm{h})$;

$T$ = período de retorno (ano);

$t=$ duração da precipitação (minuto);

$k, a, b, c=$ parâmetros relativos à localidade. 
Os parâmetros obtidos para os postos selecionados estão apresentados na Tabela 3.

Tabela 3 - Parâmetros das equações IDF para as estações selecionadas.

\begin{tabular}{cccccc}
\hline Códıgo & Nome da EstAÇÃo & $\boldsymbol{k}$ & $\boldsymbol{a}$ & $\boldsymbol{b}$ & $\boldsymbol{c}$ \\
\hline 53 & Rio Cachoeira - Captação Piracaia (E3-110T/3E-116T) & $2.000,000$ & 0,139 & 5,000 & 0,818 \\
\hline 54 & Rio Atibaia em Atibaia (E3-111T/3E-063T) & $1.625,559$ & 0,148 & 12,427 & 0,862 \\
\hline 80 & Rio Atibainha em Nazaré Paulista (3E-089T) & $1.160,115$ & 0,139 & 5,033 & 0,818 \\
\hline
\end{tabular}

A validação dos dados de nível e vazão foi realizada manualmente, por meio de análise visual que permitiu a exclusão dos dados discrepantes. A Figura 8 demonstra um exemplo de validação dos dados observados para os níveis medidos no posto 54 .

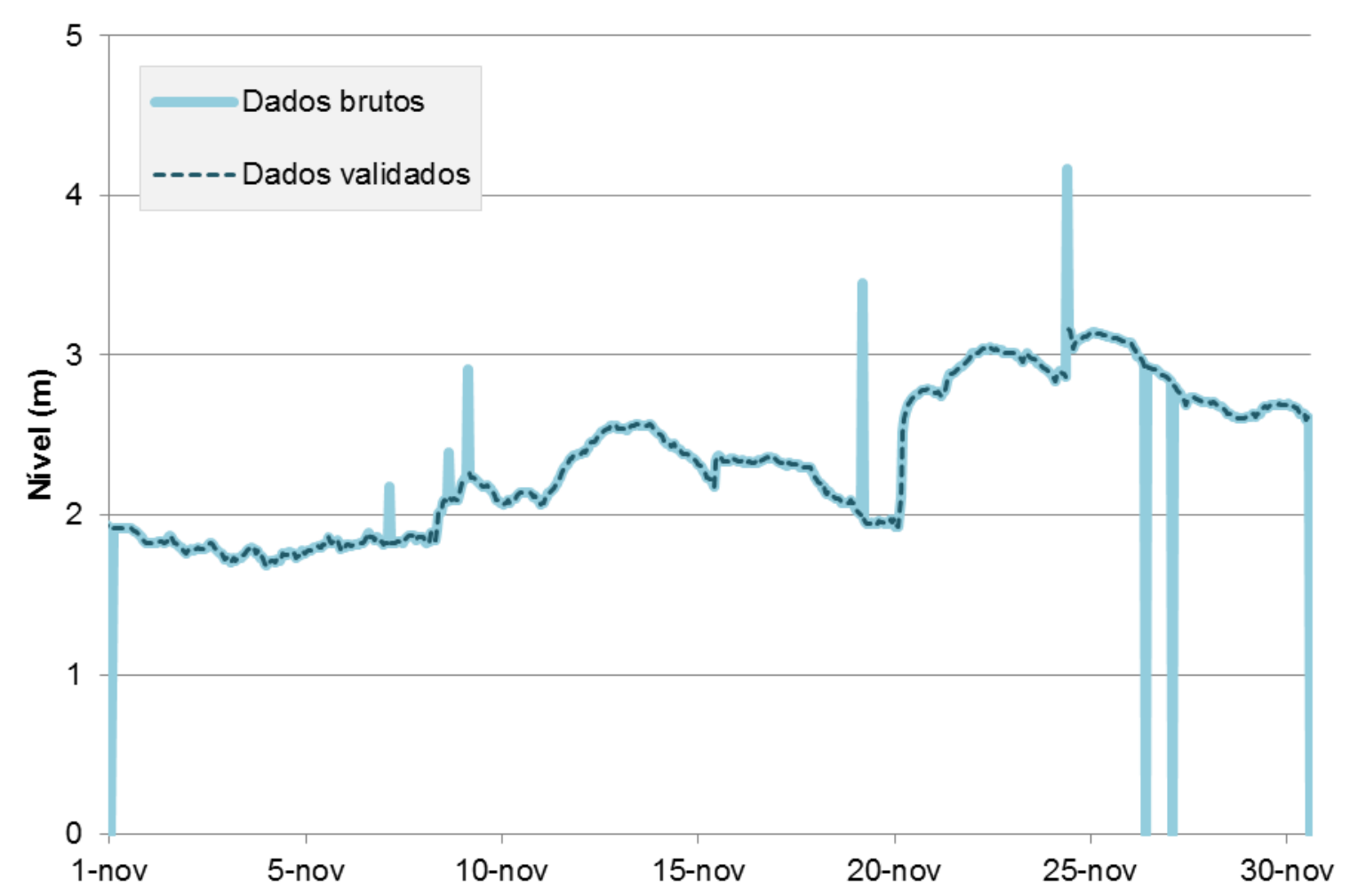

Figura 8 - Exemplo de validação de dados de nível para o posto 54 do SAISP.

A vazão para cada posto foi obtida por meio da respectiva curva-chave, apresentada na Tabela 4. 
Tabela 4 - Curvas-chave dos postos fluviométricos do SAISP.

\begin{tabular}{cc}
\hline $\begin{array}{c}\text { Código do POSTO } \\
\text { FLUVIOMÉTRICO }\end{array}$ & CURVA-CHAVE \\
\hline 53 & $\left\{\begin{array}{l}h \leq 1,46 \rightarrow Q=1,08 *(h-0,10)^{1,63} \\
h \leq 2,47 \rightarrow Q=1,14 *(h-0,20)^{1,93} \\
h>2,47 \rightarrow Q=1,70 *(h-0,70)^{2,07}\end{array}\right.$ \\
\hline 54 & $\left\{\begin{array}{l}h \leq 3,18 \rightarrow Q=8,3 *(h-0,80)^{1,28} \\
h>3,18 \rightarrow Q=7,3 *(h-1,20)^{1,81}\end{array}\right.$ \\
\hline 80 & $\left\{\begin{array}{l}h \leq 1,98 \rightarrow Q=1,07 *(h-0,00)^{1,94} \\
h>1,98 \rightarrow Q=5,30 *(h-1,10)^{2,09}\end{array}\right.$ \\
\hline
\end{tabular}

Para caracterizar os períodos de retorno das vazões que atingem a região urbana de Atibaia, foram analisadas informações obtidas a partir da base de dados da Agência Nacional de Águas (ANA) para a estação fluviométrica de código 62670000 , localizada no rio Atibaia, no município de Atibaia, com período de dados observados de 1936 a 2007. A localização deste posto também está representada na Figura 9.

A manipulação dos registros de vazões diárias se deu através do aplicativo Sistema Computacional para Análises Hidrológicas - SisCAH (2009), que constitui um programa de domínio público desenvolvido por um grupo de pesquisa coordenado pela Universidade Federal de Viçosa. Após o descarte dos meses com falhas superiores a $5 \%$, a série de vazões máximas diárias anuais (adotado outubro como o mês de início do ano hidrológico) foi ajustada a funções de distribuição de probabilidades de Gumbel, Pearson tipo III, Logpearson tipo III, Lognormal tipo II e Lognormal tipo III, considerando diferentes períodos de retorno. Ainda, para a classificação dos eventos ocorridos recentemente na região e análise da influência da operação dos reservatórios do Sistema Cantareira sobre os mesmos eventos, o estudo estatístico envolvendo as séries históricas disponíveis também considerou de forma distinta os períodos anterior e posterior a 1972, data próxima à implantação dos reservatórios. Para cada série histórica, foi escolhida a distribuição que apresentasse menor erro padrão em relação à amostra dos dados observados. 


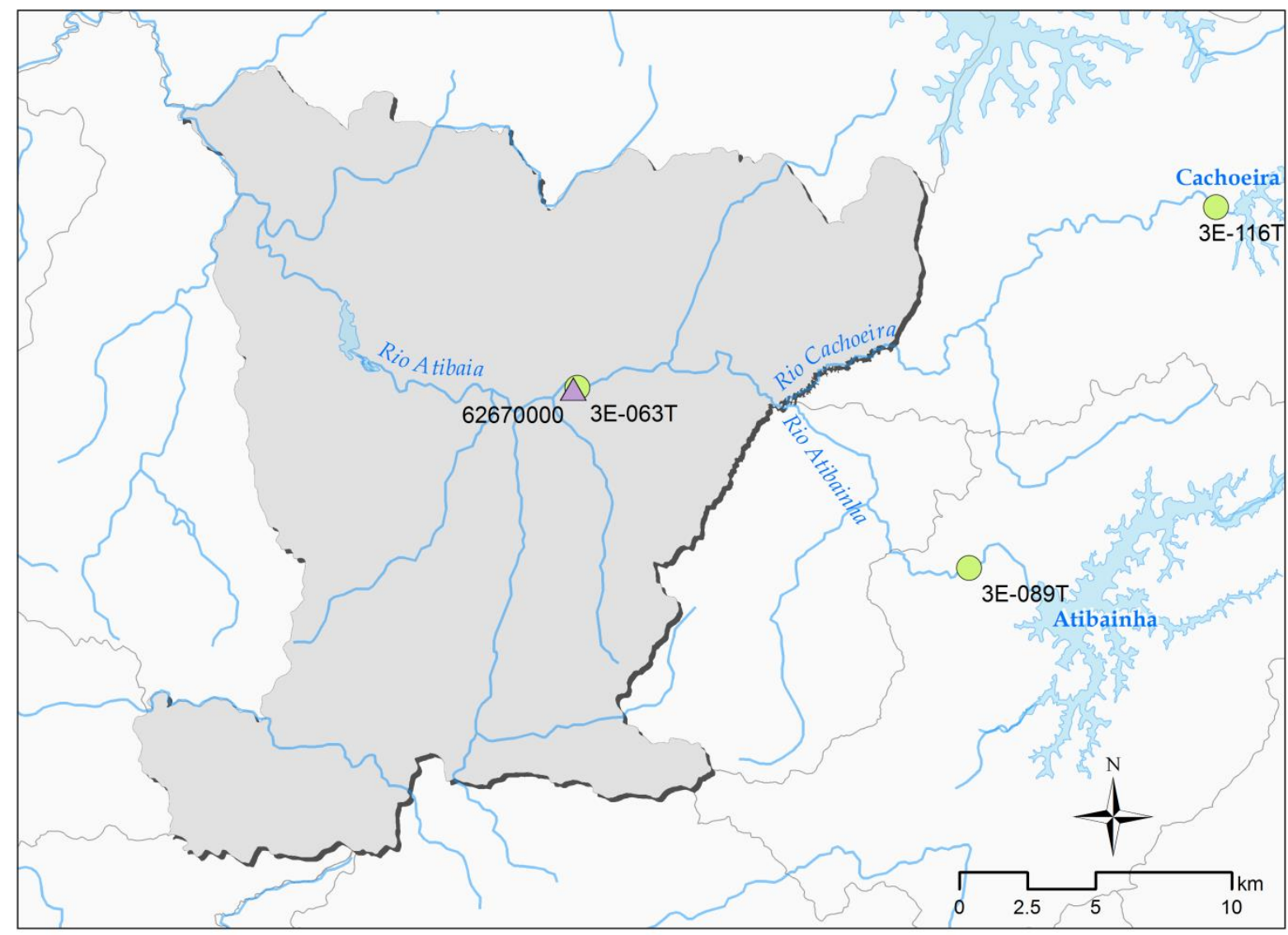

\section{Legenda}

Limites municipais

Hidrografia principal

Represas principais

\section{Postos de monitoramento}
$\triangle$ ANA
SAISP

Figura 9 - Localização dos postos de monitoramento selecionados.

\subsubsection{Análise hidráulica}

\subsubsection{Seções batimétricas ao longo do rio no perímetro urbano}

As seções batimétricas do rio Atibaia no trecho correspondente à área urbanizada de Atibaia foram obtidas a partir do levantamento topobatimétrico realizado pela Internave Engenharia no período de 18/4/2011 a 13/5/2011 (DAEE, 2011a). Ao todo, foram levantadas 40 seções ao longo do rio Atibaia entre a confluência dos rios Atibainha e Cachoeira e a represa da Usina, em trecho que compreende $23,6 \mathrm{~km}$ de 
extensão. O levantamento das margens foi realizado por GPS modo RTK (cinemática em tempo real, do inglês Real Time Kinematic), que consiste em uma técnica de navegação por satélite, onde uma estação de referência fornece correções em tempo real, permitindo um elevado nível de acurácia. A parte submersa foi aferida por ecobatímetro, com registro de posição feito por DGPS (Sistema de Posicionamento Global Diferencial, do inglês Differential Global Positioning System). Este levantamento serviu de base para o estudo Rios Atibaia e Jaguari - Estudos Hidrológicos e Hidráulicos, Zoneamento de Áreas Inundáveis e Medidas de Combate à Inundação (DAEE, 2011b).

A partir deste levantamento, foi também obtido o traçado atualizado da hidrografia do rio Atibaia no município e suas margens. Os dados estão no sistema de coordenadas SIRGAS 2000, projeção UTM.

A Figura 10 apresenta a localização das seções levantadas. Devido à limitação do levantamento topobatimétrico, a mancha de inundação será estimada apenas para o trecho a montante da represa. 


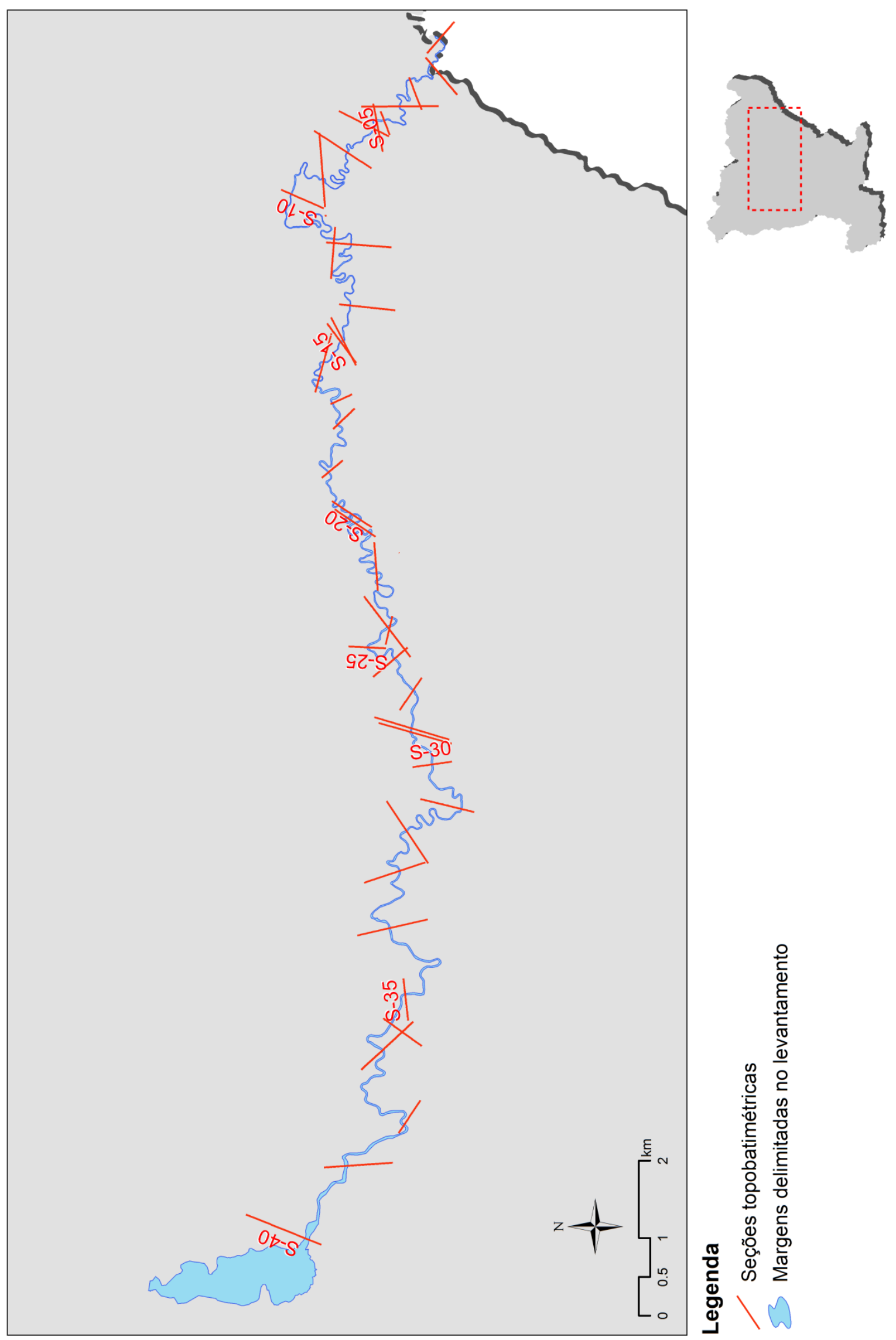

Figura 10 - Localização das seções topobatimétricas levantadas no estudo do DAEE (2011a). 


\subsubsection{Modelo Digital de Terreno}

A topografia do município será representada através de um Modelo Digital de Terreno (MDT), que corresponde a uma base de dados numéricos referentes à distribuição espacial da altitude do terreno e que pode ser obtido através de diversos processos, dentre os quais se destacam as cartas topográficas disponibilizadas pelo Instituto Brasileiro de Geografia e Estatística (IBGE), que representam os dados oficiais do relevo nacional. A partir da disponibilização de produtos advindos de outros tipos de processamento, como aerofotogrametria e sensoriamento remoto, é esperada a análise do desempenho das opções disponíveis para cada região, visando à escolha dos dados mais compatíveis com o estudo desejado. Neste sentido, Sanders (2007), Alves Sobrinho et al. (2010), Lucci et al. (2011), Tomazoni et al. (2011) e Marques et al. (2011) são alguns exemplos de trabalhos que avaliam a aplicação de dados de sensoriamento remoto em aplicações voltadas à gestão de recursos hídricos.

Diferentemente do modelo produzido a partir das curvas de nível, os dados obtidos das técnicas empregadas por sensoriamento remoto compõem a base para a geração de um Modelo Digital de Elevação (MDE), pois os sinais de radar são refletidos, por exemplo, em áreas florestadas, pelo topo da cobertura vegetal e não pelo terreno subjacente (TOMAZONI et al., 2011). Os dados devem então ser cuidadosamente comparados, para que seja possível verificar as implicações da substituição do MDT gerado a partir das curvas de nível por MDEs gerados a partir das técnicas mais recentes.

Para a escolha do modelo que melhor se adaptasse à topografia do município de Atibaia, no caso da delimitação de áreas inundáveis, foram analisados os dados SRTM (Shuttle Radar Topography Mission), adquiridos em dois diferentes níveis de processamento, realizados pela Embrapa e pela iniciativa TOPODATA, e os dados ASTER GDEM (Advanced Spaceborn Thermal Emission and Reflection Radiometer Global Digital Elevation Model), além das curvas de nível disponibilizadas pelo IBGE. Vale destacar que estas informações estão disponibilizadas gratuitamente na forma digital.

A missão SRTM, realizada em 2000, consistiu de um sistema de radar especialmente modificado que voou a bordo do ônibus espacial Endeavour, e 
disponibiliza publicamente seus dados em escala global, adotando o sistema de coordenadas WGS84. A técnica utilizada é baseada em interferometria, que envolve a recepção de um sinal de radar retrodifundida por duas antenas. A altura do terreno é, então, deduzida por meio da relação entre a diferença de fase entre os sinais, a distância entre as antenas e a localização da aeronave (SANDERS, 2007).

Os dados SRTM para o território brasileiro foram recuperados e tratados matematicamente, sendo mantida a resolução espacial original de 3 arco-segundos (aproximadamente 90 metros), e compõem a base disponibilizada pela Embrapa Monitoramento por Satélite (MIRANDA, 2005). O projeto TOPODATA consiste em um processamento digital mais recente dos dados SRTM, os quais foram refinados da resolução espacial original de 3 arco-segundos para 1 arco-segundo (aproximadamente 30 metros) por meio do método de krigagem. O refinamento pode favorecer a percepção de algumas feições, mas não se compromete a apresentar resultados aceitáveis acima dos limites originais de resolução espacial, de 3 arcosegundos (VALERIANO, 2008). No entanto, por se tratarem processamentos distintos, podem ser esperados resultados diferentes quando da adoção dos dados processados pela Embrapa e pela iniciativa TOPODATA.

O ASTER é um sensor multiespectral de captura de imagens estereoscópicas, obtidas na faixa do infravermelho próximo. No caso da América do Sul, os dados obtidos são disponibilizados na resolução espacial de 1 arco-segundo, no sistema de coordenadas WGS84. Sua distribuição gratuita foi iniciada em 2009, e encontrase atualmente em sua segunda versão (ERSDAC, 2011). A melhor resolução dos dados ASTER GDEM em relação aos dados SRTM sugere uma maior precisão nos resultados.

Para os dados da Embrapa, TOPODATA e ASTER GDEM, foi realizado um processamento simples de preenchimento de falhas, identificadas como depressões localizadas, possibilitando uma melhor consistência dos dados. A Figura 11 ilustra esta ferramenta, também conhecida por sua nomenclatura na língua inglesa, fill sinks.

Utilizou-se como base cartográfica a carta planialtimétrica de Atibaia (SF.23-Y-CIII-2), em escala 1:50.000, datum horizontal SAD-69 e datum vertical Imbituba - SC, com curvas de nível de 20 em 20 metros, restituídas pelo IBGE (1984). 


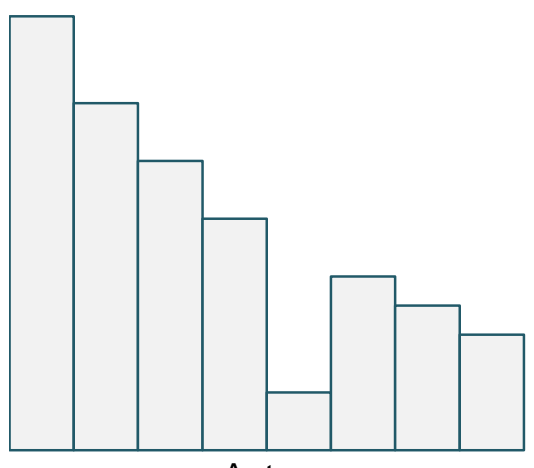

Antes

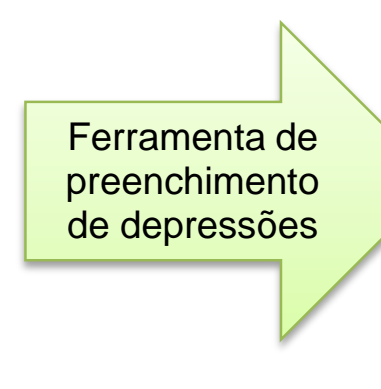

Ferramenta de preenchimento de depressões

Figura 11 - Ferramenta de preenchimento de depressões para a correção de dados numéricos de elevação

Os modelos obtidos para cada conjunto de dados foram comparados aos recentes levantamentos realizados por DAEE (2011a). Ao longo de cada seção topobatimétrica, foram calculadas as cotas mínima, média e máxima, obtidas através da interpolação dos MDTs gerados a partir das diferentes fontes de informação, o que permitiu a comparação entre os diferentes modelos.

Para o detalhamento da calha do rio Atibaia, as informações das curvas de nível ou obtidas através de sensoriamento remoto podem ser complementadas com os resultados do levantamento topobatimétrico, apresentado anteriormente. Merwade; Cook e Coonrod (2008) desenvolveram uma ferramenta que possibilita a interpolação das seções levantadas ao longo do traçado da hidrografia, para a construção do MDT na calha do rio.

As operações e o processamento do MDT foram realizados através do pacote de Sistema de Informações Geográficas ArcGIS (2010) e suas extensões, que incluem funcionalidades e análises espaciais avançadas.

\subsubsection{Dados coletados em campo}

Em complemento ao estudo e para a aferição dos resultados obtidos, foram realizadas visitas a campo para que fossem coletados com um GPS de precisão os pontos relativos aos extremos da mancha de inundação do evento ocorrido na cidade em janeiro de 2010, caracterizado por uma vazão de pico de $64,48 \mathrm{~m}^{3} / \mathrm{s}$ 
(FCTH, 2011). As visitas foram acompanhadas por técnicos da Defesa Civil do município e do DAEE. A Figura 12 apresenta imagens da coleta de dados em campo.

Além destes, foram também obtidos os pontos aferidos na cheia durante todo 0 período de dezembro de 2009 a fevereiro de 2010 (DAEE, 2010).

Com o conjunto destas informações, criou-se uma malha de pontos que proporcionou uma visão do evento e as linhas limite de inundação, nas margens direita e esquerda do rio Atibaia que delimitam a área ocupada pelas águas.
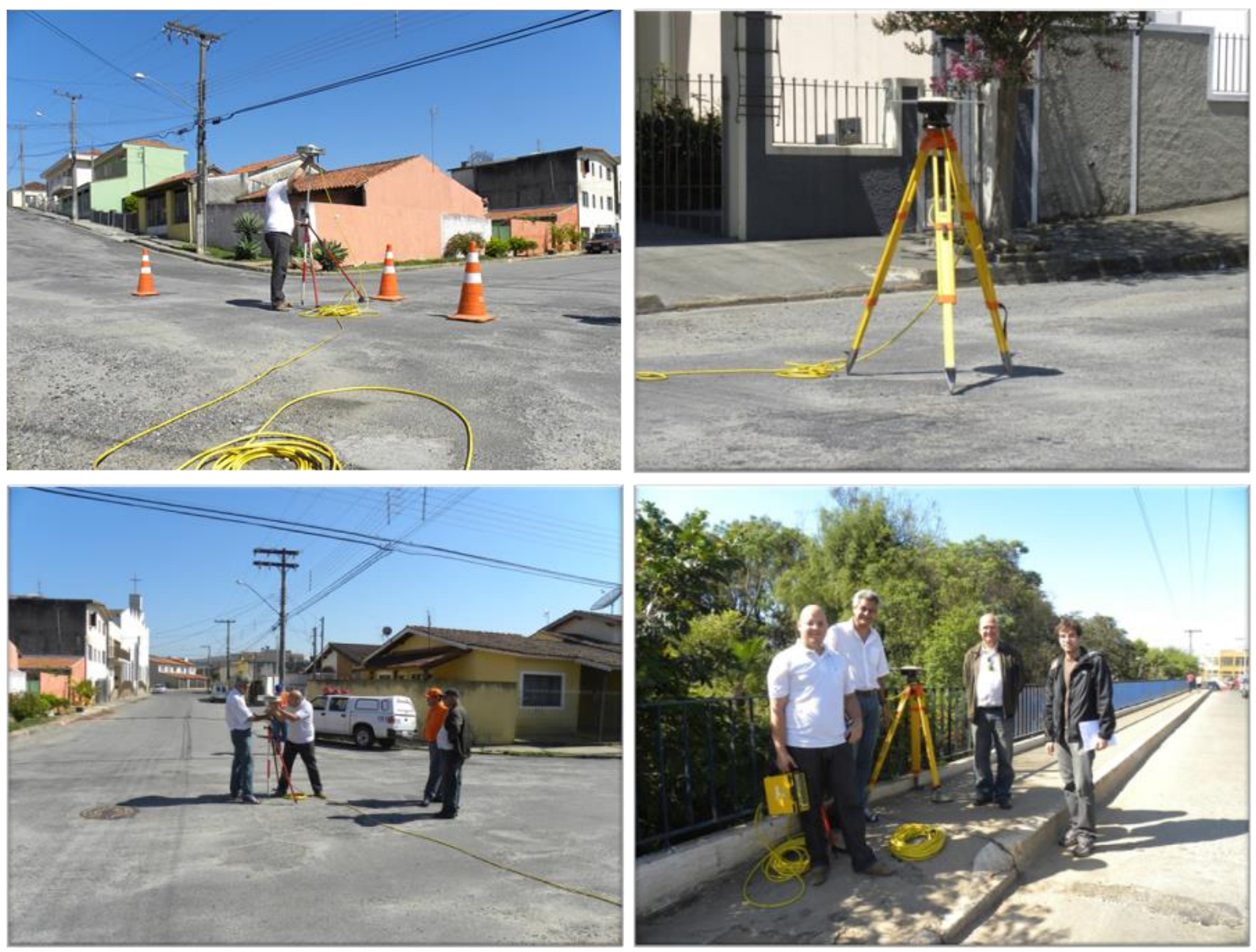

Figura 12 - Coleta de dados em campo.

\subsubsection{Modelagem matemática}

Para a modelagem hidráulica do rio Atibaia foi utilizado o aplicativo PCSWMM (2012), que consiste em uma interface que integra a aplicação do modelo SWMM a 
ferramentas avançadas de geoprocessamento e visualização de resultados. O SWMM foi desenvolvido em 1971 pela Agência de Proteção Ambiental dos Estados Unidos (USEPA, US Environmental Protection Agency), sofrendo algumas atualizações posteriores, e tem sido bastante difundido na aplicação a bacias urbanas (GARCIA, 2005), sendo um dos modelos computacionais recomendados e aceitos pela FEMA para o mapeamento de áreas de inundação como insumo ao Programa Nacional de Seguro Contra Inundações (FEMA, 2010).

O SWMM conta com módulos de simulação dos comportamentos hidrológico e hidráulico e da qualidade da água. Dentro das potencialidades do modelo de transporte hidráulico, três diferentes níveis de sofisticação podem ser selecionados fluxo em regime uniforme, onde cinemática e onda dinâmica -, sendo que, para este estudo, será adotada a forma mais simples: fluxo em regime uniforme.

O modelo de fluxo em regime uniforme considera que, em cada intervalo de tempo, o escoamento é uniforme e permanente, sendo que o hidrograma de entrada no nó de montante é transferido para o nó de jusante, sem atraso ou mudança (ROSSMAN, 2008). Para cada trecho de conduto, devem ser introduzidos no modelo parâmetros como os valores do coeficiente de Manning, do canal principal e das margens, as cotas mínimas (fundo do canal) e máximas (superfície do terreno) das seções localizadas nos nós a montante e a jusante, o comprimento do trecho e o perfil da seção transversal, obtido dos levantamentos topobatimétricos. Ainda, no nó mais a montante da rede de modelagem, são inseridas as vazões desejadas obtidas dos estudos de séries históricas de vazões. A Figura 13 apresenta a tela de inserção dos dados de uma seção transversal no aplicativo PCSWMM. 


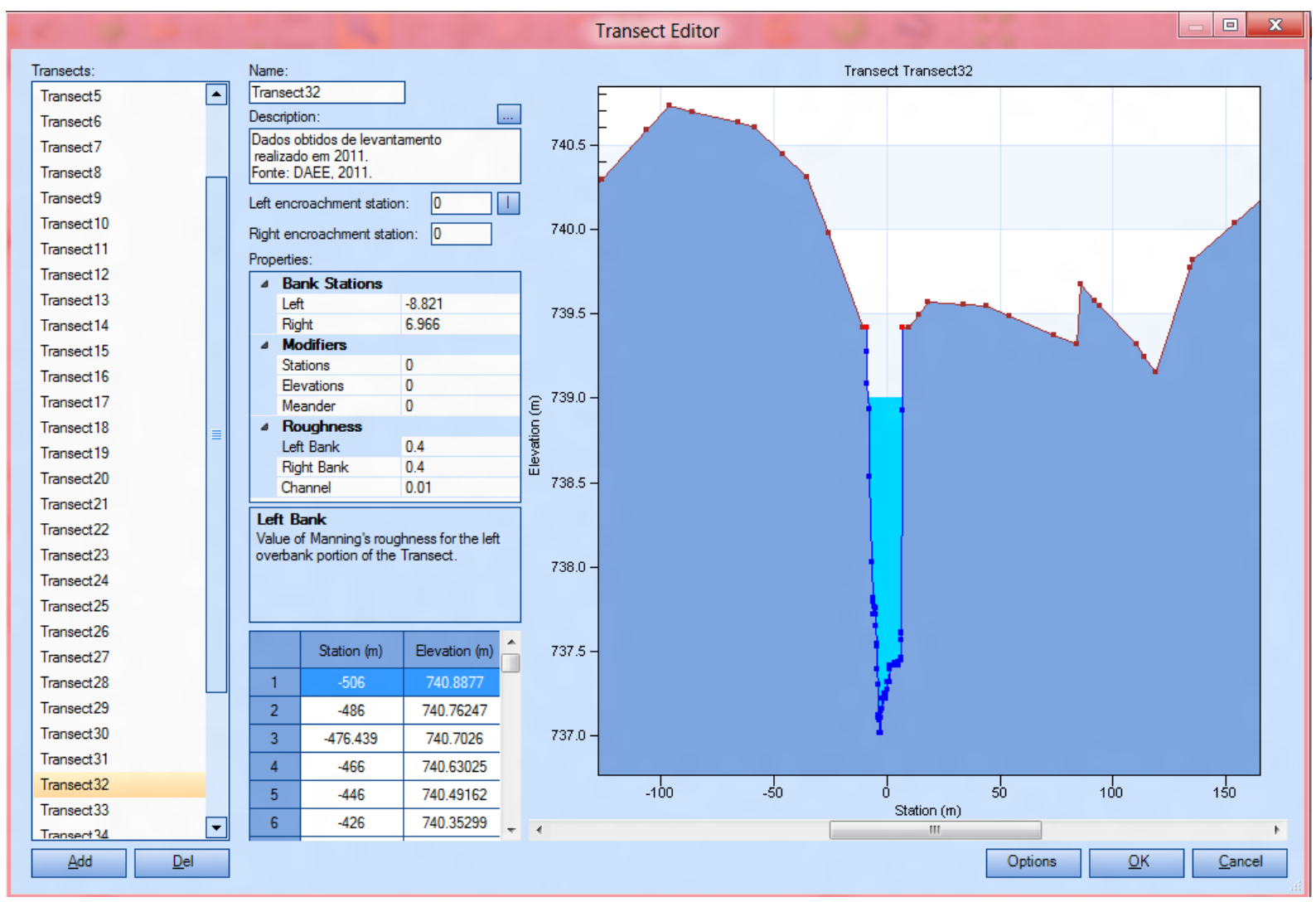

Figura 13 - Tela para entrada de dados de caracterização de uma seção transversal no aplicativo PCSWMM.

Para estabelecer a relação entre a vazão, a área e a profundidade da seção, o SWMM emprega a equação de Manning:

$$
Q=\frac{1}{n} A \cdot R_{h}^{2 / 3} \cdot \sqrt{S}
$$

Onde:

$Q=$ vazão que escoa pelo conduto $\left(\mathrm{m}^{3} / \mathrm{s}\right)$;

$A$ = área da seção transversal $\left(\mathrm{m}^{2}\right)$;

$R_{h}=$ raio hidráulico $(\mathrm{m})$;

$n$ = coeficiente de rugosidade de Manning;

$S=$ declividade do conduto $(\mathrm{m} / \mathrm{m})$.

A Tabela 5 apresenta os valores recomendados para o coeficiente de Manning em superfícies livres de acordo com McCuen et al. ${ }^{1}$ apud Rossman (2008).

1 MCCUEN, R. et al. Hydrology. FHWA-SA-96-067, Washington, DC: Federal Highway Administration, 1996. 
Tabela 5 - Coeficiente de Manning

\begin{tabular}{ccccc}
\hline SUPERFícIE & $\mathbf{N}$ & SUPERFÍcIE & N \\
\hline Asfalto liso & 0,011 & & Solos cultivados & \\
\hline Concreto liso & 0,012 & & - Cobertos de resíduos $<20 \%$ & 0,06 \\
\hline Concreto normal & 0,013 & & - Cobertos de resíduos $>20 \%$ & 0,17 \\
\hline Madeira & 0,014 & & Grama & \\
\hline Tijolo com cimento & 0,014 & & - Curta, pradaria & 0,15 \\
\hline Cerâmica & 0,015 & & - Densa & 0,24 \\
\hline Ferro fundido & 0,015 & & - Grama-bermudas & 0,41 \\
\hline Cimento com superfície de pedregulho & 0,024 & & - Vegetação rasteira leve & 0,40 \\
\cline { 1 - 2 } Solo em pousio & 0,05 & & - Vegetação rasteira densa & 0,80 \\
\hline Campo (natural) & 0,13 & & \\
\hline
\end{tabular}

Fonte: McCuen et al. apud Rossman (2008).

A altura de superfície da água obtida é então utilizada para a definição dos limites da área de inundação que correspondem aos contornos do modelo digital de terreno. Este cruzamento é realizado no próprio aplicativo PCSWMM, no qual são inseridas as informações do terreno que será interceptado pelo plano gerado pelas alturas do nível d'água obtidas no modelo.

\subsection{Uso e ocupação do solo}

O turismo é a principal atividade econômica do município de Atibaia, sendo que o setor agropecuário também contribui significativamente para a economia local, com destaque às culturas de morango, milho, feijão e gengibre, além do cultivo de flores. Atibaia abriga ainda indústrias modernas e de alta tecnologia em variados setores e segmentos, como têxtil, concreto, laticínios, náutica, metalúrgica, química, entre outros (EMPLASA, 2011).

O município abrange uma área de quase $480 \mathrm{~km}^{2}$ (IBGE, 2011a) e apresenta uma população de 126.603 habitantes dos quais $91 \%$ residem na zona urbana (IBGE, 2011b). A Figura 14 caracteriza a evolução da população residente entre 1950 e 2010, de acordo com dados do Plano Diretor (ATIBAIA, 2006) e do levantamento 
censitário realizado em 2010 (IBGE, 2011b). Nota-se, a partir da década de 1980, uma tendência de desaceleração da participação urbana, ainda que crescente, enquanto a participação da população rural parece tender a estabilizar-se em torno dos $10 \%$ da população total (ATIBAIA, 2006).

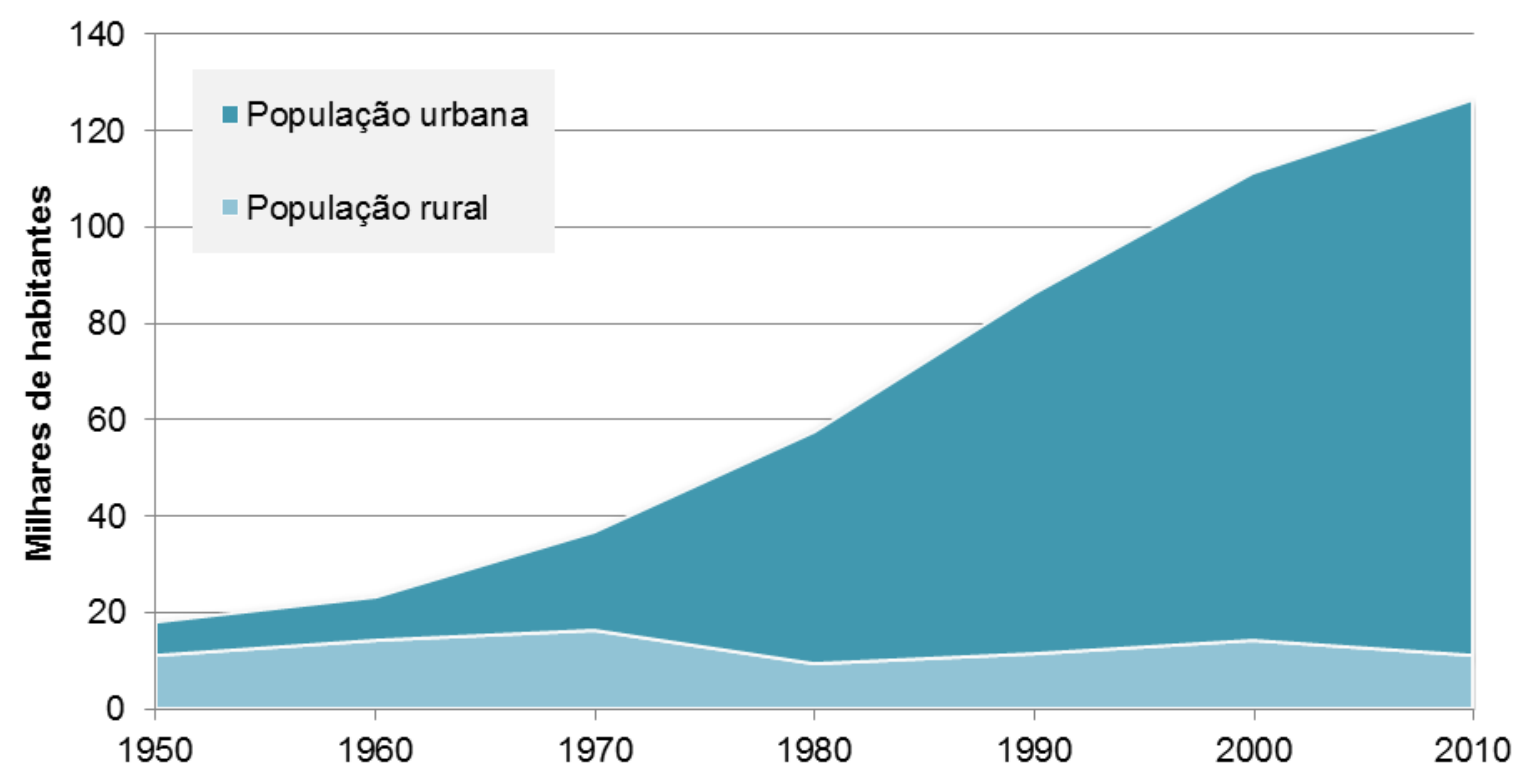

Figura 14 - Evolução da população residente no município de Atibaia entre 1950 e 2010.

A mancha urbana, por sua vez, já compreende 43\% do território (ATIBAIA, 2011) e caracteriza-se por uma elevada quantidade de polos urbanos não contíguos e baixa densidade populacional em determinadas áreas (ATIBAIA, 2006). No entanto, é possível observar que o eixo da urbanização se desenvolveu principalmente às margens do rio Atibaia e seus afluentes. A Figura 15 ilustra a hidrografia principal que drena o município e os setores urbanos de acordo com o IBGE (2011b).

Foram também levantadas as informações mais recentes relativas à densidade populacional para cada setor censitário, que constitui a unidade operacional para os trabalhos de recenseamento. Os parâmetros de densidade populacional devem formar a base para a análise da vulnerabilidade de cada setor, simplificando a metodologia aplicada por Goerl; Kobiyama e Pellerin (2012). Os autores estimaram um índice de vulnerabilidade para cada setor censitário, com base em indicadores socioeconômicos selecionados, e o relacionaram ao perigo estimado, que corresponde à porcentagem da área inundada em cada setor, resultando em um índice de risco. 
As imagens de satélite disponibilizadas por Microsoft Corporation (2010) também foram utilizadas como pano de fundo para a visualização de alguns resultados obtidos.

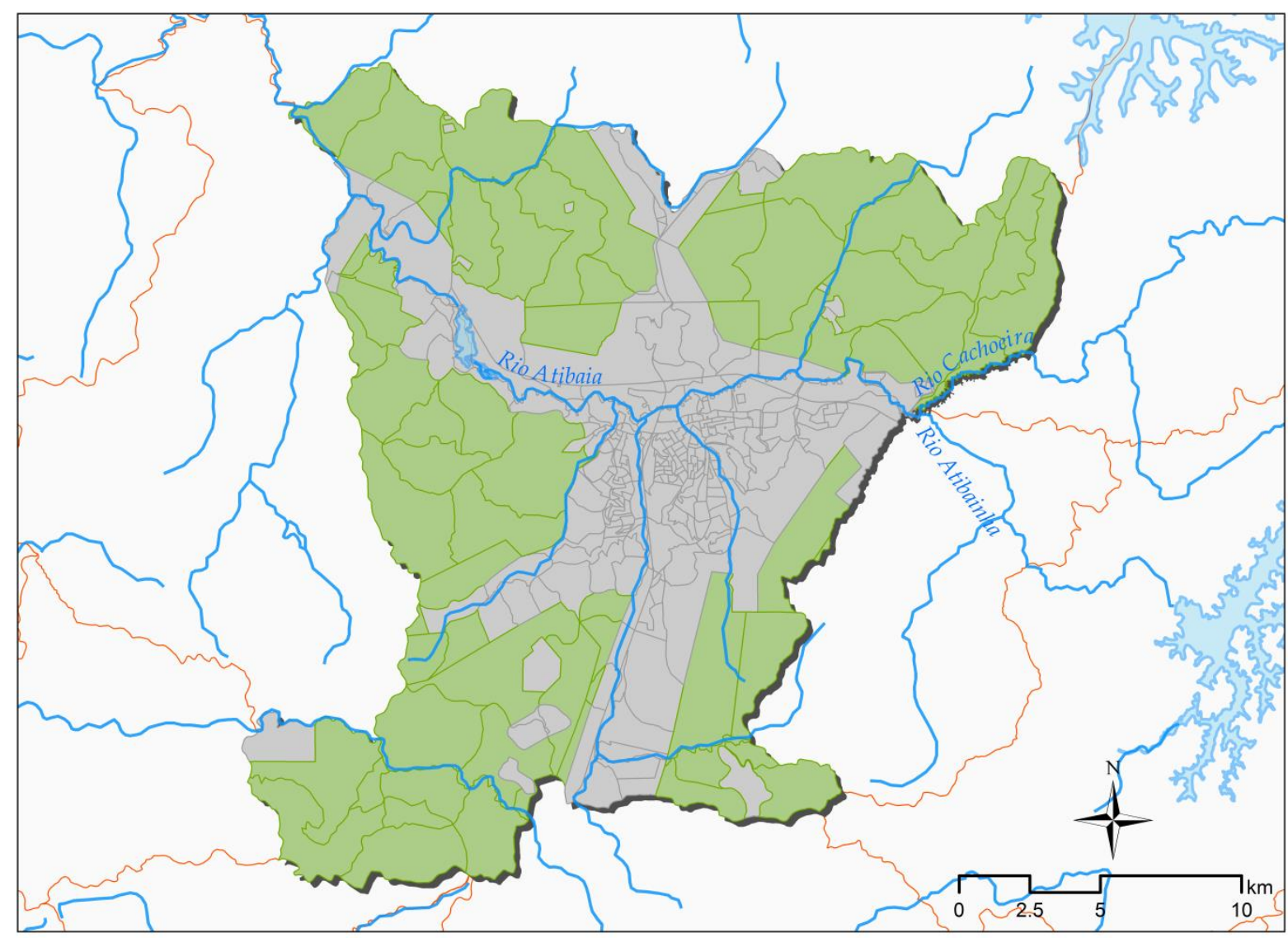

\section{Legenda}

Limites municipais

Hidrografia principal

Represas principais
Setores censitários 2010

Rurais

Urbanos

Figura 15 - Hidrografia principal e setores urbanos do município de Atibaia.

\subsubsection{Arcabouço institucional}

Conforme já mencionado, o planejamento e controle do uso e ocupação do solo urbano são definidos como competência municipal pela Constituição Federal, sendo o plano diretor o instrumento básico da política de desenvolvimento e de expansão urbana, regulamentado pelo Estatuto das Cidades. Neste caso, a formulação das 
políticas locais pelo poder municipal deve respeitar as diretrizes gerais impostas pelas normas que expressam o interesse nacional e os interesses regionais, como Estados e bacias hidrográficas. Em relação à questão ambiental e urbanística no âmbito federal, o Plano municipal de gestão do sistema de águas pluviais de São Paulo (SÃO PAULO, 2012) aponta como principais referências as leis que definem a Política Nacional do Meio Ambiente, o Código Florestal, o Estatuto das Cidades e as Diretrizes para o Saneamento Básico, que devem prevalecer sobre os interesses locais e regionais.

O ordenamento urbanístico e ambiental no município de Atibaia é dado pelo Código de Urbanismo e Meio Ambiente (CURMA), instituído por meio da Lei Complementar o 580 de 19 de dezembro de 2008. O CURMA tem o objetivo de instrumentalizar a implantação das diretrizes e objetivos expressos no Plano Diretor. Há ainda regulamentações relativas a áreas de conservação, previstas pela Lei Federal ํ․ 9.985, de 18 de julho de 2000, que rege o Sistema Nacional de Unidades de Conservação (SNUC), como as Áreas de Proteção Ambiental (APAs) Usina e Várzea do Atibaia, localizadas na região da várzea do rio Atibaia, e APA do Sistema Cantareira, que abrange todo o município, além de áreas enquadradas como Áreas de Preservação Permanente (APPs), nos termos do novo Código Florestal (Lei no 12.651 , de 25 de maio de 2012) e áreas tombadas.

A Tabela 6 lista os principais documentos legais que tratam de assuntos relevantes ao planejamento do uso do solo urbano no município de Atibaia, nas esferas federal, estadual e municipal e que serão alvo de análise. O Apêndice A Principais referências legislativas - extrai da legislação citada os artigos e incisos a serem observados para a compreensão da discussão apresentada. 
Tabela 6 - Quadro legislativo vigente que trata do planejamento do uso do solo urbano.

\begin{tabular}{|c|c|c|}
\hline ESFERA & DOCUMENTO & PRINCIPAIS ATRIBUIÇÕES \\
\hline \multirow{10}{*}{ 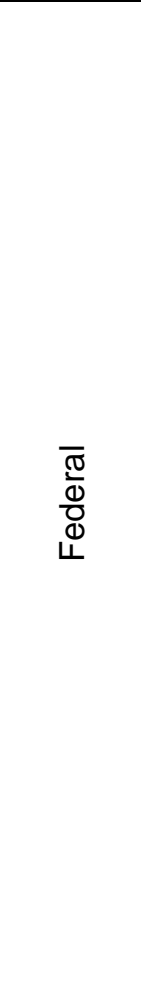 } & $\begin{array}{l}\text { Lei } n^{\circ} .6 .766 \text {, } \\
\text { de } 19 \text { de dezembro de } 1979\end{array}$ & Dispõe sobre o Parcelamento do Solo Urbano \\
\hline & $\begin{array}{l}\text { Lei } n^{\circ} .6 .938 \text {, } \\
\text { de } 31 \text { de agosto de } 1981\end{array}$ & Dispõe sobre a Política Nacional do Meio Ambiente \\
\hline & $\begin{array}{l}\text { Constituição da República } \\
\text { Federativa do Brasil de } 1988\end{array}$ & Constituição Federal \\
\hline & $\begin{array}{l}\text { Lei } n^{\circ} .9 .433 \text {, } \\
\text { de } 8 \text { de janeiro de } 1997\end{array}$ & Institui a Política Nacional de Recursos Hídricos \\
\hline & $\begin{array}{l}\text { Lei } n^{\circ} .9 .985 \text {, } \\
\text { de } 18 \text { de julho de } 2000\end{array}$ & $\begin{array}{l}\text { Institui o Sistema Nacional de Unidades de Conservação } \\
\text { da Natureza }\end{array}$ \\
\hline & $\begin{array}{l}\text { Lei } n^{\circ} .10 .257 \\
\text { de } 10 \text { de julho de } 2001\end{array}$ & $\begin{array}{l}\text { Estabelece diretrizes gerais da política urbana } \\
\text { (Estatuto das Cidades) }\end{array}$ \\
\hline & $\begin{array}{l}\text { Lei } n^{\circ} .11 .445 \text {, } \\
\text { de } 5 \text { de janeiro de } 2007\end{array}$ & $\begin{array}{l}\text { Estabelece diretrizes nacionais para o saneamento } \\
\text { básico }\end{array}$ \\
\hline & $\begin{array}{l}\text { Lei } n^{\circ} .12 .340 \text {, } \\
\text { de } 1^{\circ} \text { de dezembro de } 2010\end{array}$ & $\begin{array}{l}\text { Dispõe sobre o Sistema Nacional de Defesa Civil - } \\
\text { SINDEC }\end{array}$ \\
\hline & $\begin{array}{l}\text { Lei } n^{\circ} .12 .608 \text {, } \\
\text { de } 10 \text { de abril de } 2012\end{array}$ & $\begin{array}{l}\text { Institui a Política Nacional de Proteção e Defesa Civil - } \\
\text { PNPDEC }\end{array}$ \\
\hline & $\begin{array}{l}\text { Lei } \mathrm{n}^{\circ} .12 .651 \text {, } \\
\text { de } 25 \text { de maio de } 2012\end{array}$ & $\begin{array}{l}\text { Dispõe sobre a proteccão da vegetação nativa; revoga a } \\
\text { Lei n'. } 4.771 / 1965 \text { | "Novo Código Florestal" }\end{array}$ \\
\hline \multirow{6}{*}{$\begin{array}{l}\bar{\pi} \\
\frac{\pi}{0} \\
\frac{\pi}{00} \\
w\end{array}$} & $\begin{array}{l}\text { Lei Estadual } n^{\circ} 5.280 \text {, } \\
\text { de } 4 \text { de setembro de } 1986\end{array}$ & $\begin{array}{l}\text { Declara área de proteção ambiental a região que } \\
\text { circunda a represa hidrelétrica do Bairro da Usina }\end{array}$ \\
\hline & $\begin{array}{l}\text { Constituição do Estado de São } \\
\text { Paulo de } 1989\end{array}$ & Constituição Estadual \\
\hline & $\begin{array}{l}\text { Lei no. } 7.663 \text {, } \\
\text { de } 30 \text { de dezembro de } 1991\end{array}$ & $\begin{array}{l}\text { Estabelece normas de orientação à Política Estadual de } \\
\text { Recursos Hídricos }\end{array}$ \\
\hline & $\begin{array}{l}\text { Decreto } n^{\circ} .40 .151 \\
\text { de } 16 \text { de junho de } 1995\end{array}$ & Reorganiza o Sistema Estadual de Defesa Civil \\
\hline & $\begin{array}{l}\text { Lei } n^{\circ} .13 .798, \\
\text { de } 9 \text { de novembro de } 2009\end{array}$ & $\begin{array}{l}\text { Institui a Política Estadual de Mudanças Climáticas - } \\
\text { PEMC }\end{array}$ \\
\hline & $\begin{array}{l}\text { Decreto no } 57.512 \text {, } \\
\text { de } 11 \text { de novembro de } 2011\end{array}$ & $\begin{array}{l}\text { Institui o Programa Estadual de Prevenção de Desastres } \\
\text { Naturais e de Redução de Riscos Geológicos }\end{array}$ \\
\hline \multirow{4}{*}{ 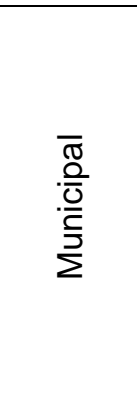 } & $\begin{array}{l}\text { Lei Complementar no. } 507 \text {, } \\
\text { de } 5 \text { de outubro de } 2006\end{array}$ & $\begin{array}{l}\text { Dispõe sobre o Plano Diretor da Estância de Atibaia, para } \\
\text { o período } 2007 / 2016\end{array}$ \\
\hline & $\begin{array}{l}\text { Lei Complementar no. } 580 \\
\text { de } 19 \text { de dezembro de } 2008\end{array}$ & $\begin{array}{l}\text { Institui o Código de Urbanismo e Meio Ambiente da } \\
\text { Estância de Atibaia }\end{array}$ \\
\hline & $\begin{array}{l}\text { Lei Municipal } n^{0} .3 .705 \text {, } \\
\text { de } 19 \text { de dezembro de } 2008\end{array}$ & $\begin{array}{l}\text { Institui a Área de Proteção Ambiental - APA - Várzeas } \\
\text { do Atibaia }\end{array}$ \\
\hline & $\begin{array}{l}\text { Lei Orgânica, } \\
\text { de } 23 \text { de fevereiro de } 2012\end{array}$ & $\begin{array}{l}\text { Dispõe sobre a revisão e consolidação da Lei Orgânica } \\
\text { Municipal }\end{array}$ \\
\hline
\end{tabular}




\section{RESUltados E DISCUSSÕES}

Neste capítulo são apresentados os resultados das análises hidrológica e hidráulica como base para o mapeamento das áreas inundáveis, bem como as propostas de medidas de intervenção no ordenamento da ocupação no município.

\subsection{Mapeamento das áreas inundáveis}

\subsubsection{Análise hidrológica}

Os dados consolidados de precipitação mensal (FCTH, 2012) para toda a série histórica dos postos telemétricos 53, 54 e 80 estão apresentados nos gráficos da Figura 16. Os valores registrados mensalmente nos anos de 2009, 2010 e 2011 em cada posto também estão apresentados na Figura 16.

A análise das chuvas acumuladas mensalmente nos permite observar que, para as séries dos postos 53 e 54, o mês de janeiro de 2011 apresentou o maior índice pluviométrico, enquanto, para o posto 80 , localizado no rio Atibainha, apesar de o mês de janeiro de 2011 ter apresentado um valor muito superior à média histórica daquele posto, os valores acumulados registrados em janeiro de 2010 foram ainda mais elevados. Já os meses de agosto de 2010, julho e setembro de 2011 apresentam valores próximos de zero para os três postos observados.

A análise visual dos valores exibidos na Figura 16 indica possíveis erros de medição para o posto 54 durante o primeiro semestre de 2009, o que sugere a necessidade de realização de consistência dos dados obtidos através da telemetria.

$\mathrm{Na}$ comparação das séries pluviométricas às curvas IDF, realizada no estudo de FCTH (2012), destacou-se que:

- Para o posto 53 , a precipitação com maior período de retorno observado corresponde a uma chuva de $88,00 \mathrm{~mm}$, com duração de 100 minutos, ocorrida 
em 26 de dezembro de 2010, e que está relacionada a um período de retorno de 176,2 anos;

- Para o posto 54 , a precipitação com maior período de retorno observado corresponde a uma chuva de $65,75 \mathrm{~mm}$, com duração de 1 hora, ocorrida em 29 de março de 2011, e que está relacionada a um período de retorno de 26,3 anos;

- Para o posto 80, a precipitação com maior período de retorno observado corresponde a uma chuva de $95,00 \mathrm{~mm}$, com duração de 5,5 horas (330 minutos), ocorrida em 11 de janeiro de 2011, e que está relacionada a um período de retorno de 51,9 anos.

Os níveis observados em 2009, 2010 e 2011 para o posto 54, localizado no rio Atibaia, estão apresentados na Figura 17, que apresenta também o nível de referência para o início do extravasamento nesta seção de controle, correspondente a 3,0 metros, de acordo com o SAISP. Na sequência, a Figura 18 apresenta os dados de vazão estimados para os anos de 2009, 2010 e 2011 através dos níveis observados nos três postos selecionados da rede telemétrica do SAISP.

A análise dos dados de precipitação e nível leva a crer que as inundações ocorridas na região entre 2009 e 2011 tenham sido ocasionadas pelo elevado volume de chuva. Os meses de novembro e dezembro de 2009 e 2010, que antecederam os eventos mais críticos de precipitação, foram em geral bastante chuvosos, fato que deve ter contribuído para a saturação do solo e agravado os impactos dos maiores picos.

As recentes discussões acerca do aquecimento global também nos permitem questionar se as altas precipitações registradas correspondem a uma tendência das mudanças climáticas ou simplesmente fazem parte das variações de um período mais longo. Para esta questão, as séries observadas ainda são muito limitadas e não permitem uma conclusão sólida.

A análise hidrológica realizada por Silva et al. (2011) para o diagnóstico das inundações sucedidas entre dezembro de 2009 e fevereiro de 2010 e em janeiro de 2011 demonstra a suscetibilidade da região a vazões de baixa magnitude. A análise hidrológica das vazões máximas ocorridas no rio Atibaia, a partir da base de dados da ANA, resultou nas distribuições apresentadas na Tabela 7 e também na Figura 19. 

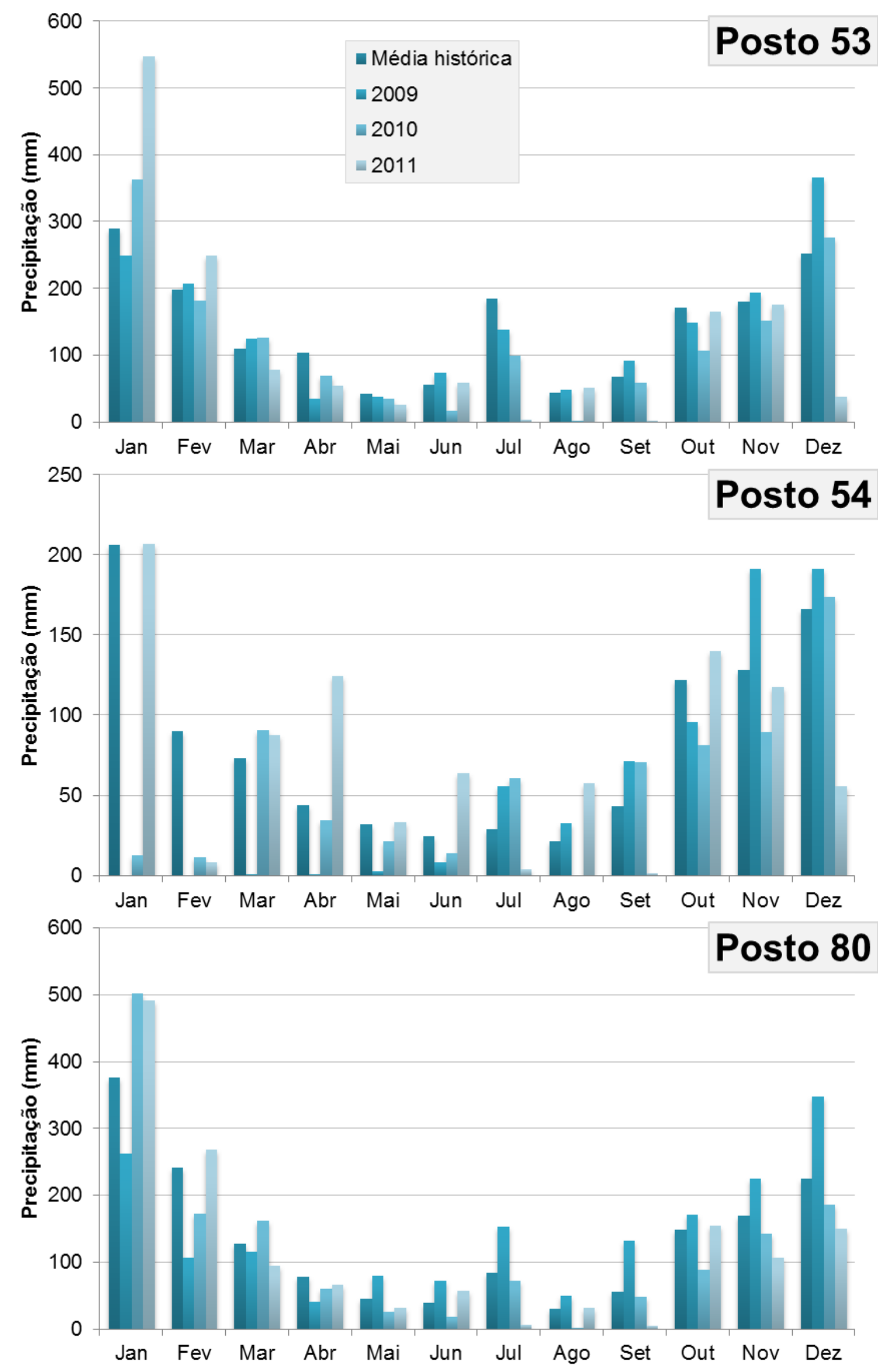

Figura 16 - Precipitações mensais registradas nos postos telemétricos selecionados. 

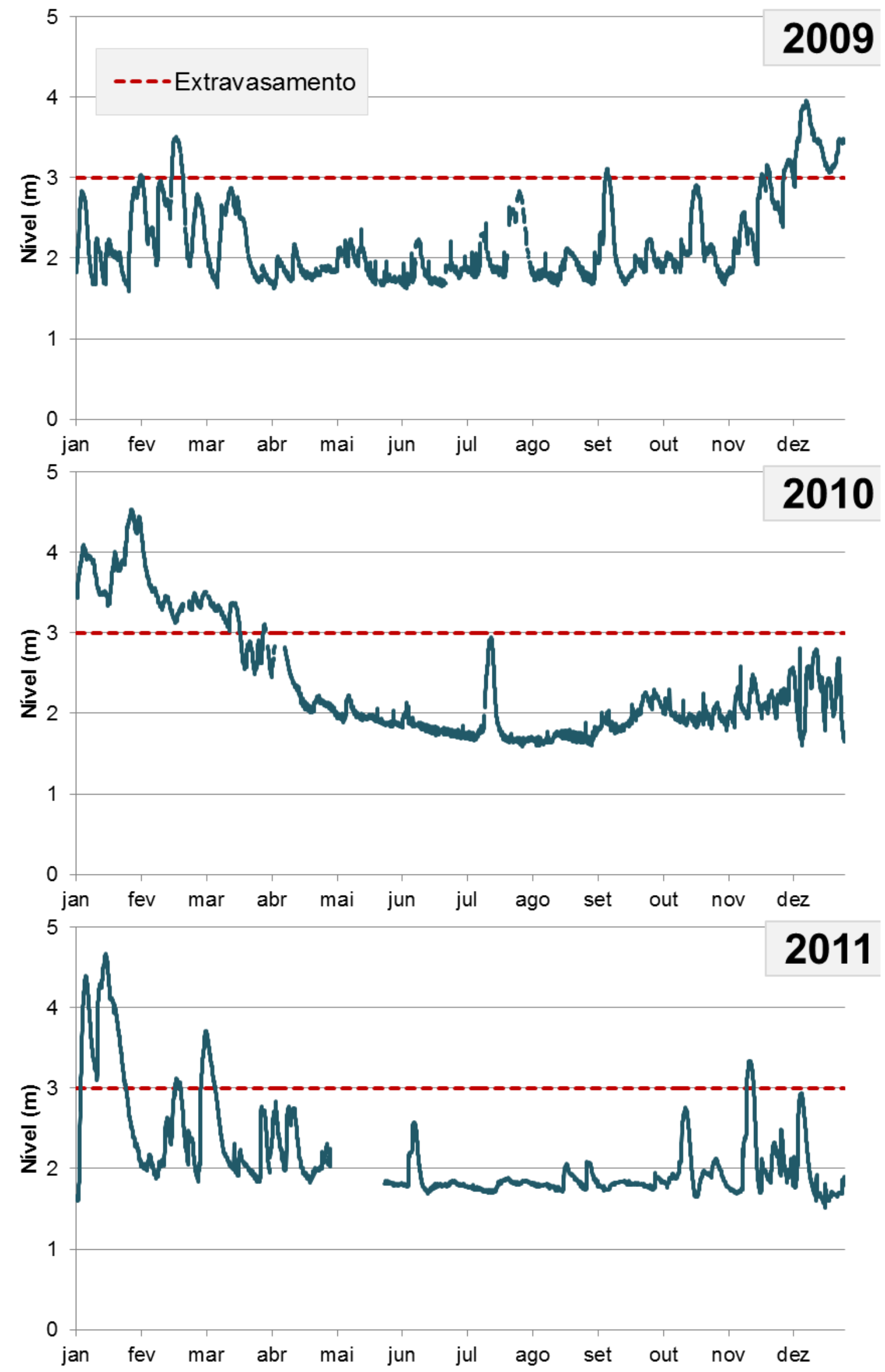

Figura 17 - Níveis observados em 2009, 2010 e 2011 no posto 54 (Rio Atibaia em Atibaia). 

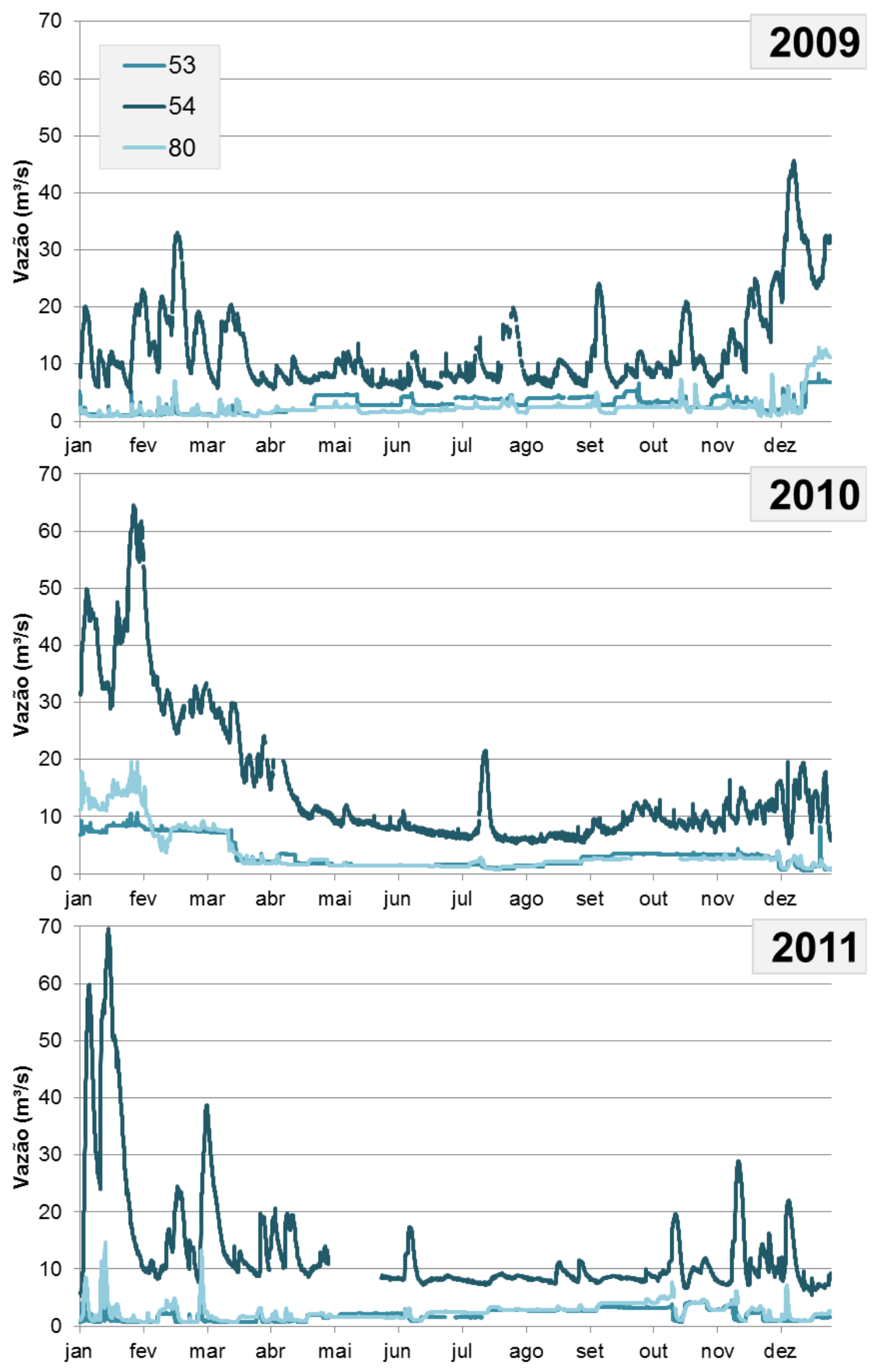

Figura 18 - Vazões estimadas em 2009, 2010 e 2011 nos postos da rede telemétrica analisados. 
Tabela 7 - Distribuição das vazões máximas no rio Atibaia, no município de Atibaia, para o posto 62670000 da ANA.

\begin{tabular}{cccc}
\hline \multirow{2}{*}{$\begin{array}{c}\text { PeRíodo DE RETORNO } \\
\text { (ANOS) }\end{array}$} & \multicolumn{2}{c}{ VAZÃo DE PICO (M³/S) - DistRIBUIÇÃo LOGNORMAL II } \\
\cline { 2 - 4 } & $\begin{array}{c}\text { SÉRIE COMPLETA } \\
\text { (DE 1936 A 2007) }\end{array}$ & DE 1936 A 1972 & DE 1972 A 2007 \\
\hline 2 & 49,56 & 60,89 & 40,07 \\
\hline 3 & 57,80 & 69,24 & 45,20 \\
\hline 4 & 63,06 & 74,47 & 48,40 \\
\hline 5 & 66,95 & 78,29 & 50,72 \\
\hline 6 & 70,03 & 81,29 & 52,54 \\
\hline 7 & 72,59 & 83,76 & 54,03 \\
\hline 8 & 74,77 & 85,86 & 55,30 \\
\hline 9 & 76,67 & 87,68 & 56,40 \\
\hline 10 & 78,36 & 89,29 & 57,37 \\
\hline 15 & 84,76 & 95,34 & 61,01 \\
\hline 20 & 89,24 & 99,53 & 63,52 \\
\hline 25 & 92,68 & 102,72 & 65,43 \\
\hline 50 & 103,29 & 112,45 & 71,22 \\
\hline 100 & 113,86 & 121,99 & 76,87 \\
\hline 500 & 138,68 & 143,84 & 89,71 \\
\hline 1000 & 149,60 & 153,24 & 95,19 \\
\hline
\end{tabular}

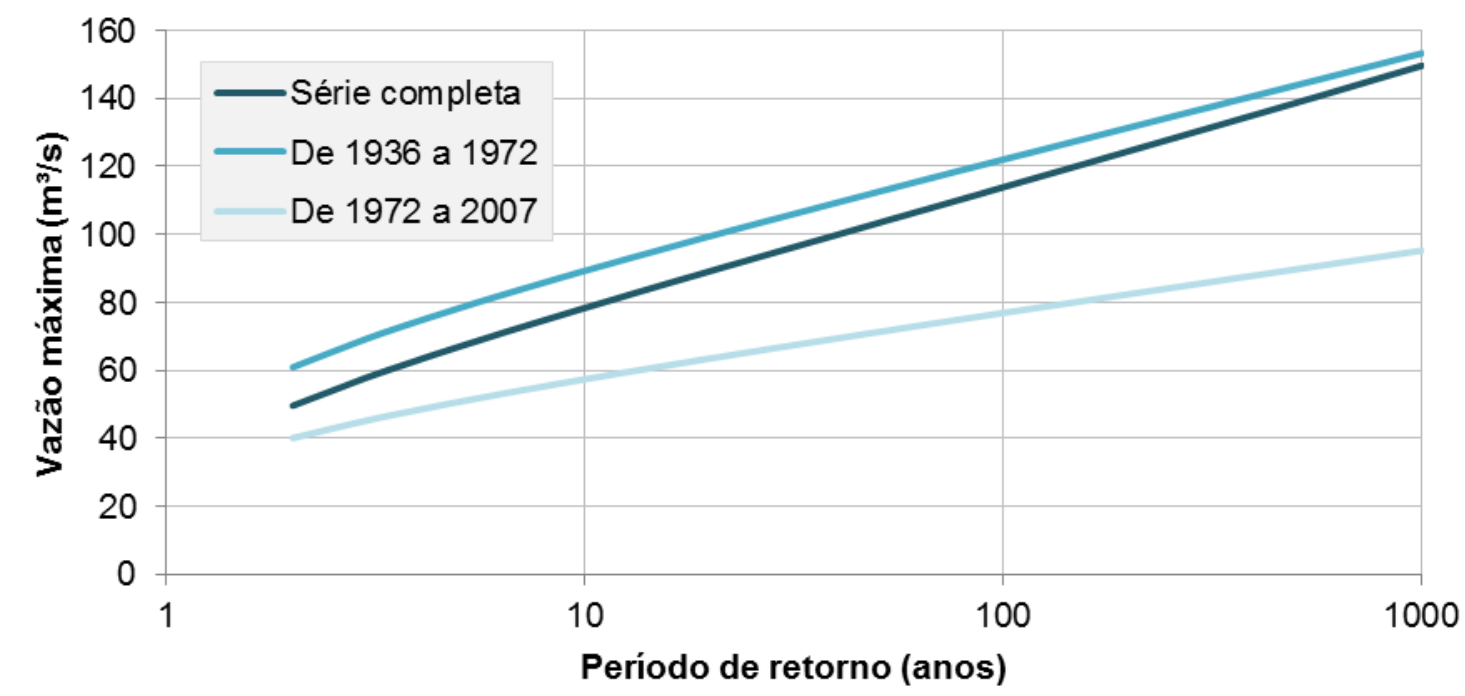

Figura 19 - Distribuição das vazões máximas no rio Atibaia, no município de Atibaia, para o posto 62670000 da ANA.

Analisando os períodos da série completa e também das séries anterior e posterior a 1972, é interessante observar uma provável mudança no regime hidrológico, possivelmente influenciada pela implementação das barragens do 
Sistema Cantareira. Tal alteração pode ser considerada benéfica, do ponto de vista de controle de cheias, uma vez que é razoável afirmar que os reservatórios causam efeito de amortecimento nas vazões de pico a jusante dos mesmos. Os valores obtidos a partir da distribuição dos dados observados após a implantação dos reservatórios serviram de base para a análise hidráulica, apresentada no tópico a seguir.

Uma análise dos níveis máximos observados no posto 54 e suas vazões correspondentes (vide Figura 17 e Figura 18, respectivamente), entre os anos de 2009 e 2011, permite relacionar as vazões aos períodos de retorno calculados para o mesmo trecho do rio Atibaia, conforme a Tabela 7 e a Figura 19. Esta relação está apresentada na Tabela 8.

Tabela 8 - Níveis e vazões máximos registrados no posto 54 (Rio Atibaia em Atibaia) entre 2009 e 2011 e períodos de retorno associados.

\begin{tabular}{cccc}
\hline DatA & Nível (M) & VAzÃo (M $\left.{ }^{3} / \mathbf{S}\right)$ & $\begin{array}{c}\text { Período de RetoRno } \\
\text { APROXIMADo (ANOS) }\end{array}$ \\
\hline $17 / 02 / 2009$ & 3,51 & 33,15 & menor que 2 \\
\hline $13 / 12 / 2009$ & 3,96 & 45,73 & 3 \\
\hline $26 / 01 / 2010$ & 4,53 & 64,48 & 22 \\
\hline $14 / 01 / 2011$ & 4,68 & 69,65 & 42 \\
\hline $03 / 03 / 2011$ & 3,71 & 38,59 & 2 \\
\hline $16 / 11 / 2011$ & 3,34 & 28,91 & menor que 2 \\
\hline
\end{tabular}

A partir de uma relação entre as vazões de pico destacadas e os períodos de retorno calculados para o mesmo trecho do rio Atibaia, é possível afirmar que mesmo com vazões de magnitude não tão elevada, ou seja, de alta recorrência, já se tem graves problemas relacionados a inundações. O nível mínimo de extravasamento $(3,0 \mathrm{~m})$ na seção de controle do rio Atibaia, localizado no município de Atibaia, corresponde a uma vazão de $22,44 \mathrm{~m} 3 / \mathrm{s}$, que está relacionada a um período de retorno inferior a 2 anos. Sendo assim, é natural que o nível de extravasamento da calha do rio Atibaia nesta seção seja frequentemente superado.

Em dezembro de 2009, por exemplo, a vazão máxima ocorrida na área urbana de Atibaia foi de $45,73 \mathrm{~m}^{3} / \mathrm{s}$, o que corresponde a cerca de 3 anos de período de retorno. Tal evento já implicou na elevação de quase 1 metro acima do nível de extravasamento das margens do rio Atibaia na região e marcou o início de um período de graves impactos relacionados às inundações. $O$ maior pico registrado 
naquele verão ocorreu ao final de janeiro de 2010, quando a vazão na seção do rio Atibaia alcançou $64,48 \mathrm{~m} / \mathrm{s}$, equivalente a um evento com probabilidade de recorrência de 22 anos. Mesmo com a diminuição das chuvas e um perfil de vazões descendente, é possível observar a demora na assimilação destas vazões de pico, fato que manteve os níveis d'água em estado crítico ainda durante todo o mês de fevereiro e parte do mês de março de 2010. A Figura 20 mostra a permanência do nível d'água no rio Atibaia no posto 54, entre 1ํ de dezembro de 2009 e 31 de março de 2010. Observa-se que, neste período, o nível do rio Atibaia se manteve acima do nível crítico de extravasamento em $88 \%$ do tempo.

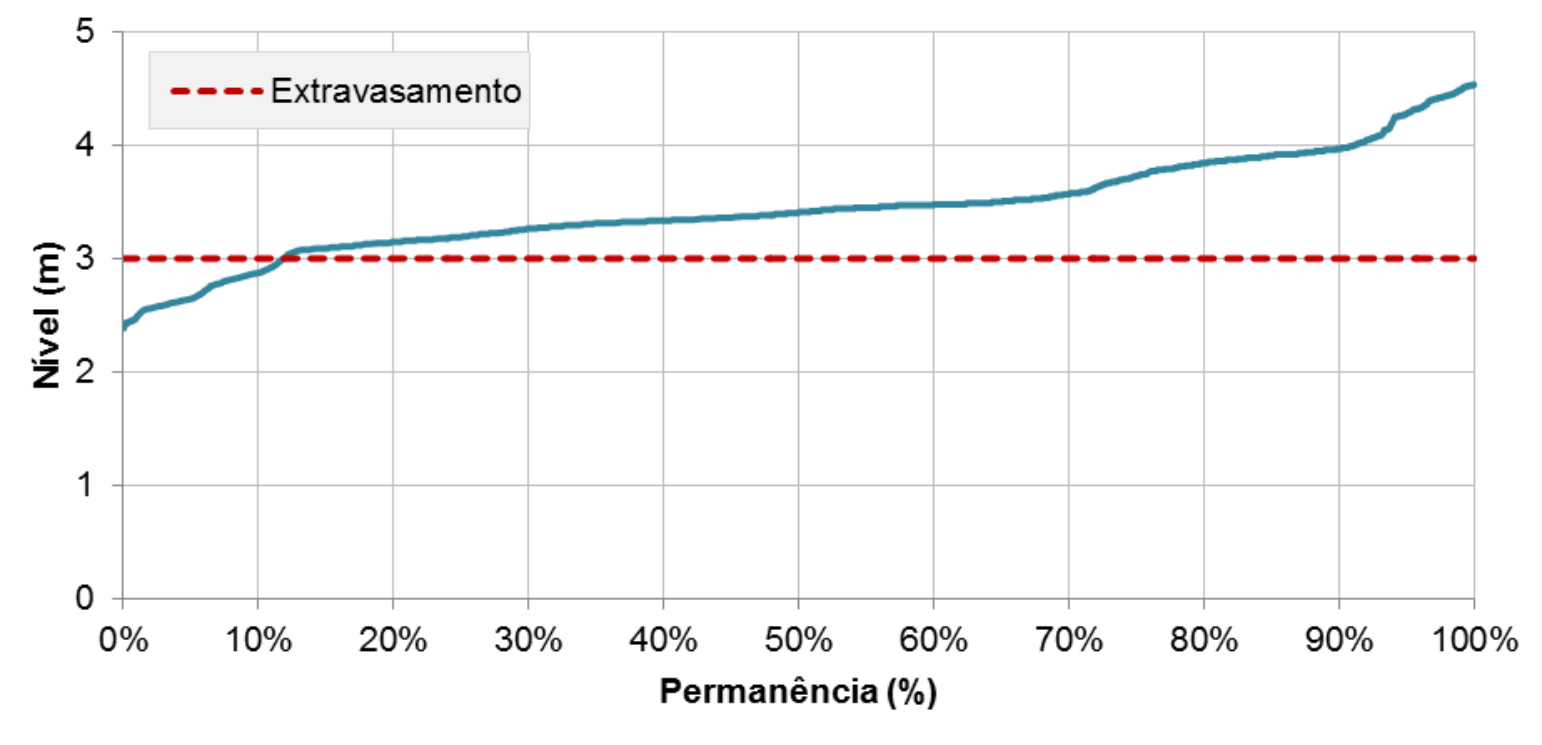

Figura 20 - Permanência dos níveis observados entre 1\%/dez/2009 e 31/mar/2010 no posto 54 (Rio Atibaia em Atibaia).

Segundo o argumento de parte da população atingida pelos eventos, a responsabilidade pelo aumento das inundações seria em parte da Companhia de Saneamento Básico do Estado de São Paulo (Sabesp), que opera, nas proximidades, as represas do Sistema Cantareira, para o abastecimento de parte da Região Metropolitana de São Paulo, e que englobam os rios Jaguari, Jacareí, Cachoeira e Atibainha, os quais verteriam em situações desfavoráveis em direção às cidades localizadas a jusante, como é o caso do município de Atibaia. No entanto, as constantes inundações da região estudada vêm se repetindo após o inicio de uma temporada bastante chuvosa, marcada pelas fortes cheias ocorridas entre dezembro de 2009 e março de 2010, e não se devem exclusivamente à presença de estruturas de descarga nos afluentes do rio Atibaia, que mantiveram seus níveis 
normais de operação nos últimos eventos. A ideia de que graves impactos relacionados a inundações seriam ocasionados mesmo em eventos de baixo período de retorno ganhou força quando, em janeiro do ano seguinte, foram registrados novos picos de cheia consecutivos, sendo o maior pico ainda mais intenso que aqueles ocorridos no ano anterior.

O diagnóstico das recentes inundações ocorridas no município de Atibaia demonstra a suscetibilidade da região a vazões de baixa magnitude. Isso ocorre apesar do sistema de operação dos reservatórios, que causa efeito de amortecimento e minimiza os impactos causados pelas chuvas. A contribuição das vazões nos postos a jusante dos reservatórios Cachoeira e Atibainha, integrantes do sistema Cantareira, foi apresentada na Figura 18. A seguir, a Figura 21 representa em maior detalhe uma análise das vazões ocorridas em dezembro de 2009, nas seções dos rios Cachoeira e Atibainha, a jusante dos respectivos reservatórios, e do rio Atibaia, de acordo com os postos fluviométricos da rede do SAISP.

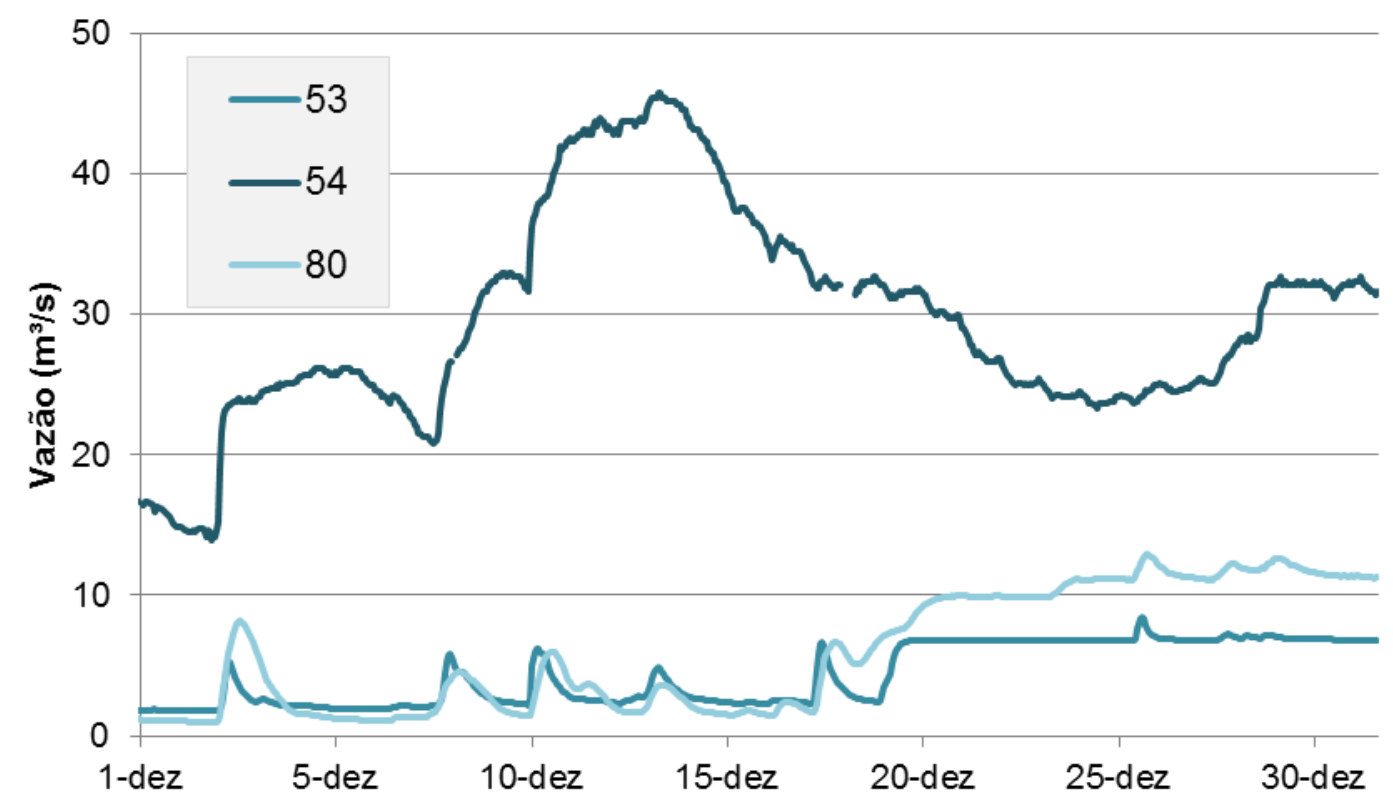

Figura 21 - Contribuição dos reservatórios para as vazões ocorridas no rio Atibaia em dezembro de 2009.

As diferenças entre a soma das vazões dos afluentes à vazão do próprio rio Atibaia chegam a quase $40 \mathrm{~m}^{3} / \mathrm{s}$, o que demonstra que a descarga dos reservatórios é muito pequena em relação à vazão total que passa no rio Atibaia, sendo a contribuição da bacia, a jusante dos reservatórios do sistema Cantareira, a principal responsável pelos grandes volumes de água que atingiram a região de Atibaia nesta época. 
A conclusão da análise dos eventos de cheia entre 2009 e 2011 realizada por DAEE (2011b) também remete ao fato de tais eventos não serem totalmente dependentes das vazões descarregadas a partir dos reservatórios Atibainha e Cachoeira, sendo que "a própria bacia que abrange a área urbanizada de Atibaia tem capacidade de gerar eventos significativos de cheia com inundação da várzea".

\subsubsection{Análise hidráulica}

\subsubsection{Modelo Digital de Terreno}

As cotas mínima, média e máxima estimadas ao longo de cada seção, obtidas através da interpolação dos MDTs gerados a partir dos dados da Embrapa, TOPODATA, ASTER GDEM e curvas de nível, estão plotadas na Figura 22, que também apresenta o perfil gerado com os dados das seções de acordo com o levantamento do DAEE (2011a). Na sequência, a Tabela 9 apresenta os valores para as elevações médias ao longo das seções, comparadas com os levantamentos topobatimétricos. 


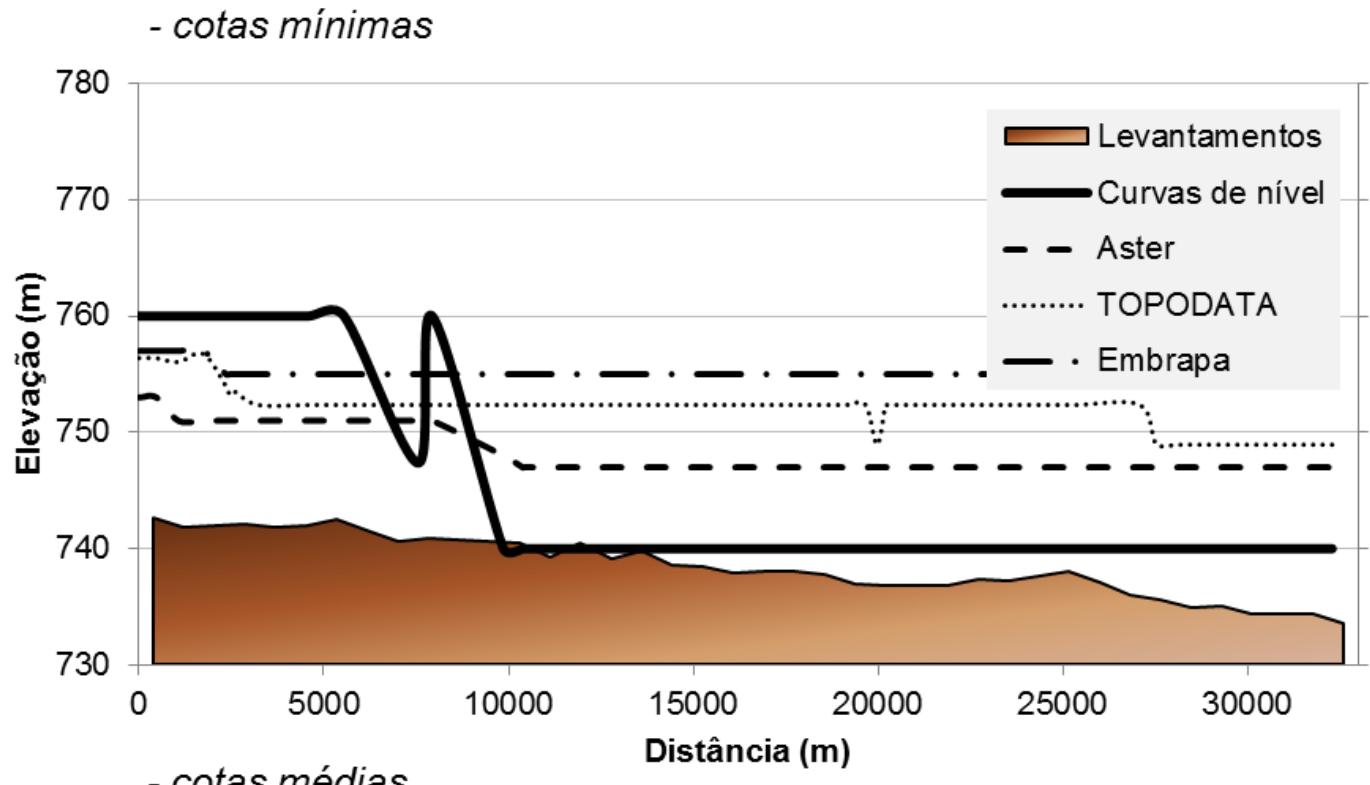

- cotas médias

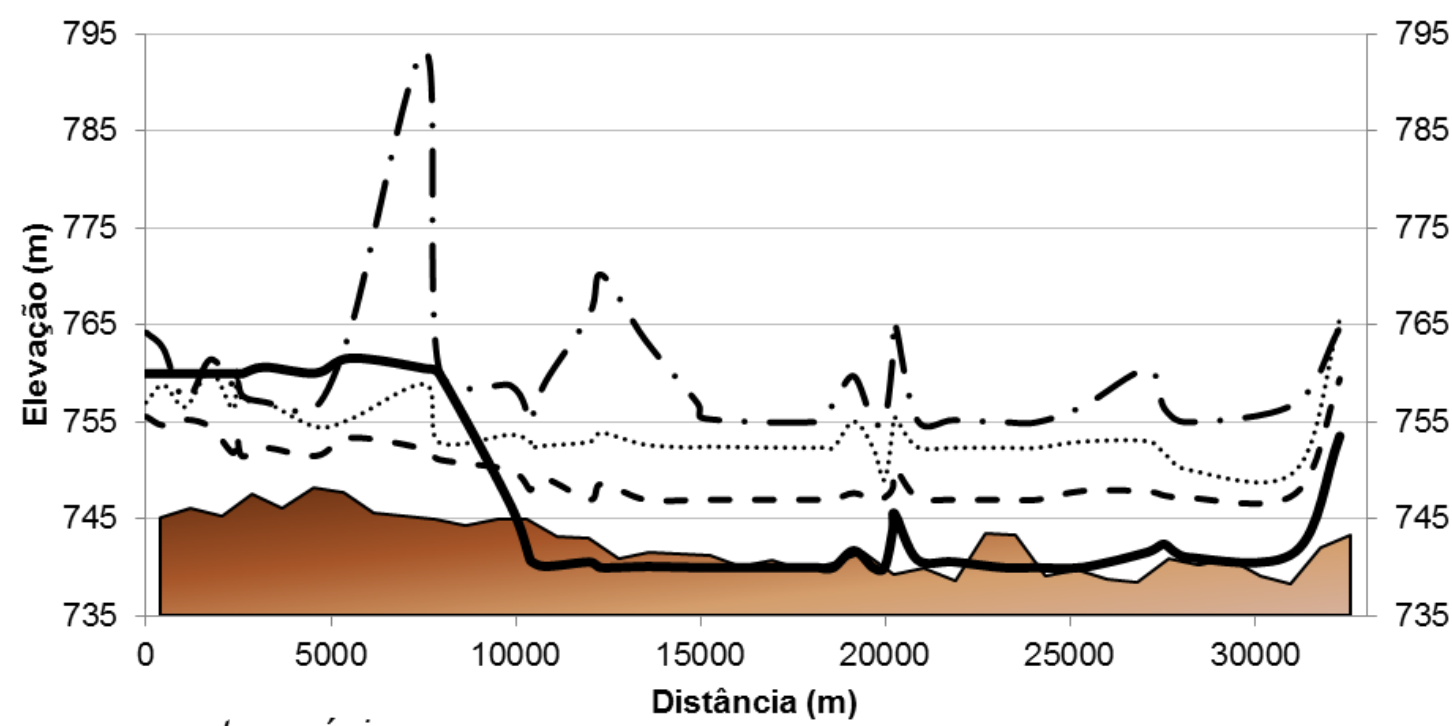

- cotas máximas

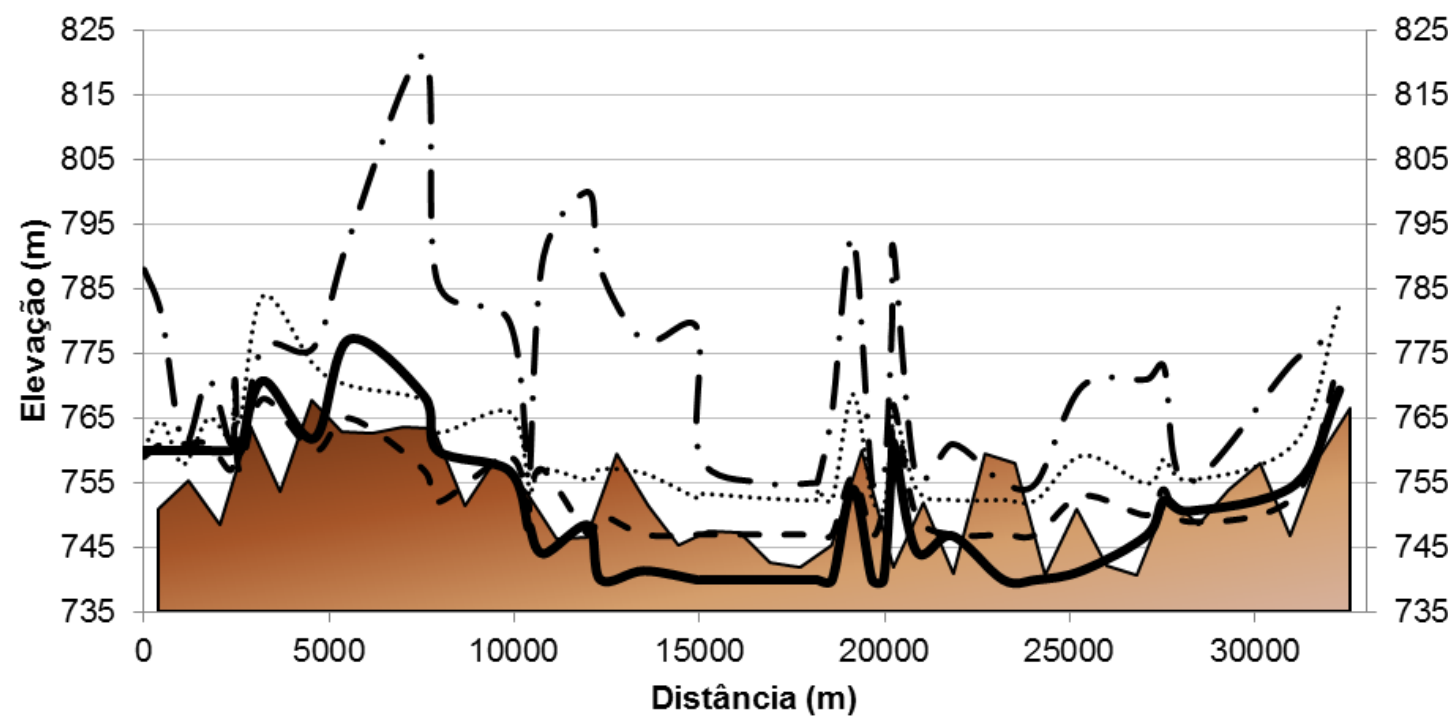

Figura 22 - Comparação das elevações interpoladas para os diferentes MDT ao longo das seções topobatimétricas levantadas. 
Tabela 9 - Elevação média nas seções topobatimétricas a partir dos diferentes MDTs.

\begin{tabular}{|c|c|c|c|c|c|}
\hline \multirow{2}{*}{ SeÇÃo } & \multirow{2}{*}{$\begin{array}{l}\text { EXTENSÃO } \\
\text { (M) }\end{array}$} & \multicolumn{4}{|c|}{ ELEVAÇÃO MÉDIA (M)å } \\
\hline & & CuRVAS de NÍvel & ASTER GDEM & TOPODATA & EMBRAPA \\
\hline 01 & 516,8 & 14,88 & 10,47 & 11,92 & 19,13 \\
\hline 02 & 633,4 & 13,91 & 8,57 & 12,75 & 16,48 \\
\hline 03 & 452,0 & 14,81 & 10,07 & 11,38 & 12,02 \\
\hline 04 & 1000,4 & 12,53 & 7,05 & 12,79 & 13,99 \\
\hline 05 & 324,3 & 13,96 & 5,78 & 10,32 & 12,78 \\
\hline 06 & 632,5 & 11,86 & 5,64 & 11,86 & 11,86 \\
\hline 07 & 722,5 & 12,26 & 3,75 & 9,58 & 10,02 \\
\hline 08 & 887,7 & 15,18 & 6,87 & 11,61 & 11,58 \\
\hline 09 & 962,6 & 14,88 & 6,34 & 9,34 & 11,39 \\
\hline 10 & 601,0 & 16,62 & 8,39 & 10,34 & 19,83 \\
\hline 11 & 674,7 & 16,28 & 7,96 & 14,63 & 49,03 \\
\hline 12 & 844,5 & 15,11 & 6,25 & 8,02 & 15,55 \\
\hline 13 & 729,5 & 1,50 & 5,08 & 8,77 & 13,84 \\
\hline 14 & 697,7 & $-2,17$ & 4,90 & 9,94 & 11,86 \\
\hline 15 & 630,7 & $-2,29$ & 5,09 & 9,46 & 12,04 \\
\hline 16 & 756,4 & $-0,73$ & 8,33 & 11,72 & 18,20 \\
\hline 17 & 307,7 & $-0,94$ & 5,50 & 11,47 & 24,63 \\
\hline 18 & 384,4 & $-1,40$ & 7,24 & 12,52 & 28,78 \\
\hline 19 & 351,5 & $-1,05$ & 5,84 & 11,52 & 22,31 \\
\hline 20 & 612,8 & $-0,06$ & 6,94 & 12,33 & 16,79 \\
\hline 21 & 635,1 & $-0,64$ & 6,36 & 11,84 & 14,82 \\
\hline 22 & 629,6 & 0,34 & 7,34 & 12,72 & 15,34 \\
\hline 23 & 375,0 & $-0,34$ & 6,66 & 12,02 & 14,66 \\
\hline 24 & 989,2 & $-1,44$ & 5,56 & 11,06 & 13,56 \\
\hline 25 & 487,6 & 0,84 & 7,84 & 13,20 & 17,68 \\
\hline 26 & 583,9 & 1,80 & 7,74 & 15,13 & 19,78 \\
\hline 27 & 505,6 & 1,39 & 8,39 & 13,75 & 16,39 \\
\hline 28 & 510,3 & $-3,43$ & 3,80 & 5,64 & 11,57 \\
\hline 29 & 1008,7 & 0,54 & 4,88 & 11,08 & 18,42 \\
\hline 30 & 977,4 & 6,52 & 11,24 & 16,50 & 26,29 \\
\hline 31 & 513,6 & 1,08 & 7,50 & 12,69 & 15,50 \\
\hline 32 & 715,3 & 1,81 & 8,21 & 13,58 & 16,43 \\
\hline 33 & 968,3 & 1,54 & 8,54 & 13,91 & 16,54 \\
\hline 34 & 835,0 & $-0,79$ & 6,21 & 11,57 & 14,21 \\
\hline 35 & 932,0 & $-0,20$ & 7,68 & 12,77 & 16,41 \\
\hline 36 & 545,7 & 0,81 & 7,08 & 12,25 & 19,67 \\
\hline 37 & 610,6 & 3,40 & 8,42 & 12,77 & 17,38 \\
\hline 38 & 915,6 & 2,78 & 8,90 & 11,80 & 16,73 \\
\hline 39 & 890,0 & $-0,30$ & 5,69 & 8,03 & 15,00 \\
\hline 40 & 1050,1 & 10,19 & 16,10 & 22,29 & 21,38 \\
\hline \multicolumn{2}{|c|}{ Média $(\mathrm{m})$} & 4,78 & 7,26 & 11,92 & 17,25 \\
\hline \multicolumn{2}{|c|}{ Desvio padrão (m) } & 6,79 & 2,21 & 2,64 & 6,61 \\
\hline
\end{tabular}

a em relação aos levantamentos topobatimétricos 
Através da análise dos dados apresentados, observa-se que as diferentes metodologias de obtenção de dados do terreno apresentam resultados bastante discrepantes, principalmente em relação aos valores máximos em cada seção. Em relação às cotas mínimas, que corresponderia ao ponto mais baixo da seção do rio, pode-se verificar uma tendência linear em todas as técnicas empregadas - curvas de nível, Embrapa, TOPODATA e ASTER GDEM - que se deve não só às baixas resoluções de todas as metodologias, mas também ao fato de não haver detalhamento na calha do rio em nenhuma delas. Além disso, as cotas mínimas e médias são, em geral, superiores às cotas do levantamento topobatimétrico, sendo que as curvas de nível representam a metodologia que mais se aproxima dos dados levantados, com exceção do trecho mais a montante, estando, em média, 4,8 m acima dos valores levantados.

Em relação aos dados obtidos por sensoriamento remoto, a hipótese de que a melhor resolução dos dados ASTER GDEM em comparação aos dados SRTM refletiria uma melhor precisão nos resultados se confirma. Do mesmo modo, os dados processados pela Embrapa apresentam precisão inferior ao refinamento realizado pelo projeto TOPODATA.

As grandes diferenças entre as cotas mínimas e médias dos levantamentos topobatimétricos e dos dados obtidos por sensoriamento remoto sugerem, ainda, a interferência da cobertura vegetal no processamento das altitudes, diferentemente das curvas de nível, que representam a altura do terreno de modo mais adequado. Este resultado já era esperado, pois, no caso do sensoriamento remoto, são consideradas as alturas captadas pelo sensor em pontos que são interpolados para que seja gerada uma superfície que representa uma aproximação do terreno natural, no caso, o Modelo Digital de Elevação e, principalmente nas áreas de margens, as quais geralmente são ocupadas por mata ciliar com vegetação alta, as imagens passam a apresentar pontos com grandes desníveis em relação ao solo. Assim, estes pontos são retratados como regiões altas, e, quando traçadas as seções no processamento, podem aparecer como ilhas, conforme pode ser observado na Figura 23. Valeriano (2008) afirma que a sensibilidade a estes efeitos pode afetar ocasionalmente o aproveitamento dos dados, sendo que "estes erros representam um prejuízo incontornável da confiabilidade dos resultados". 


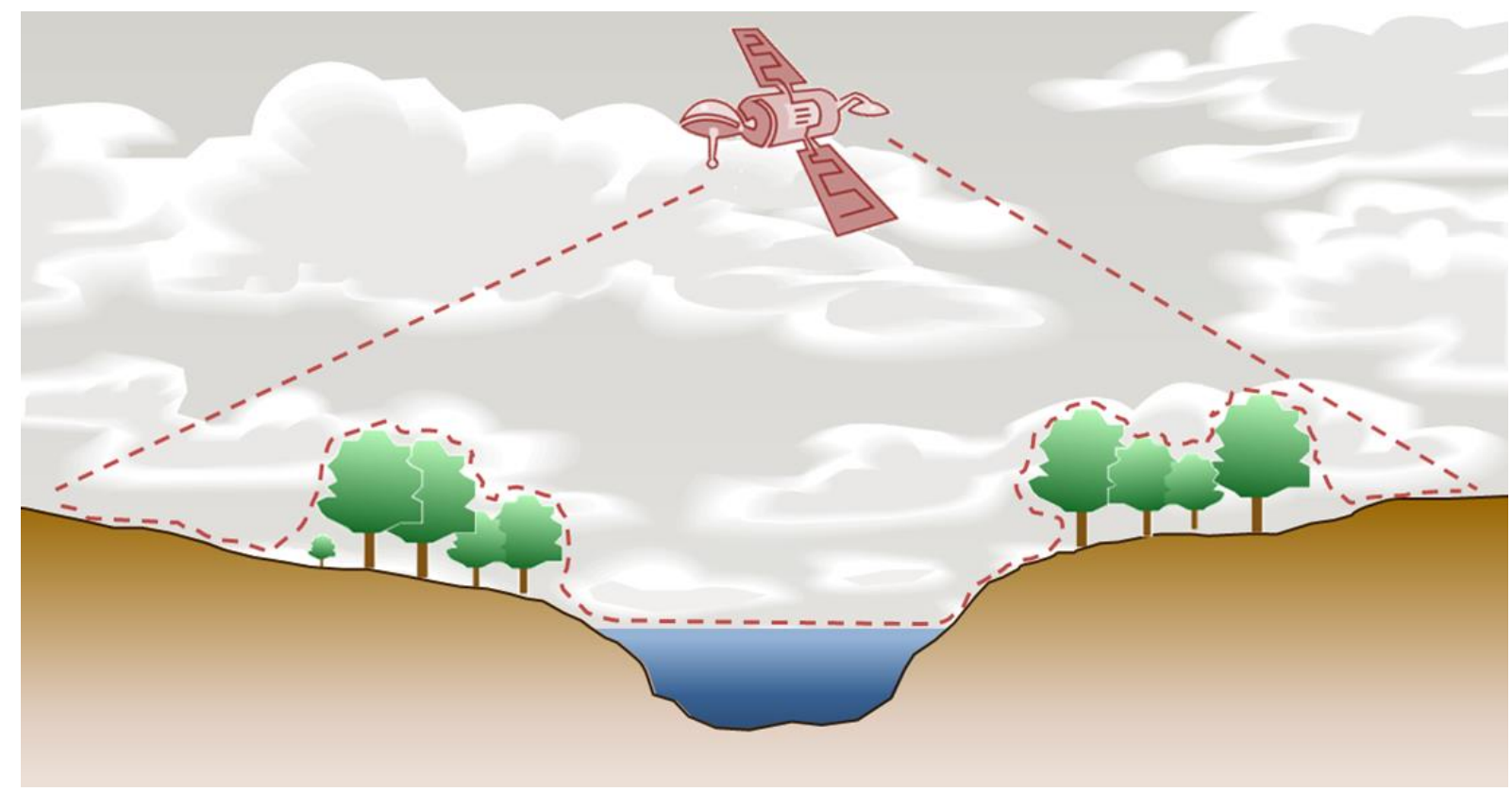

Figura 23 - Sobrelevação da superfície do terreno induzida pela altura da vegetação numa seção de rio.

Conclui-se que a substituição das curvas de nível por dados obtidos através de sensoriamento remoto representa uma considerável diminuição na precisão dos resultados, no caso da delimitação das manchas de inundação. Ainda assim, os dados obtidos por teledetecção são uma opção quando as cartas topográficas estiverem indisponíveis, sendo observadas suas limitações. Neste caso, os dados ASTER GDEM possibilitam resultados mais precisos em relação aos dados SRTM.

Ainda que as curvas de nível se apresentem como melhor opção, o detalhamento na calha do rio é bastante limitado e pode ser aperfeiçoado através de ferramentas específicas. A Figura 24 apresenta em detalhe o resultado da aplicação da ferramenta desenvolvida por Merwade; Cook e Coonrod (2008) e que foi utilizada para aprimorar o MDT na calha do rio Atibaia. A aplicação desta ferramenta limitase, no entanto, ao contorno das margens do rio e não leva em conta os levantamentos realizados nas áreas de várzea.

Na sequência, a Figura 25 apresenta o MDT resultante, a partir das curvas de nível e dos levantamentos topobatimétricos, para a região da várzea do rio Atibaia. 


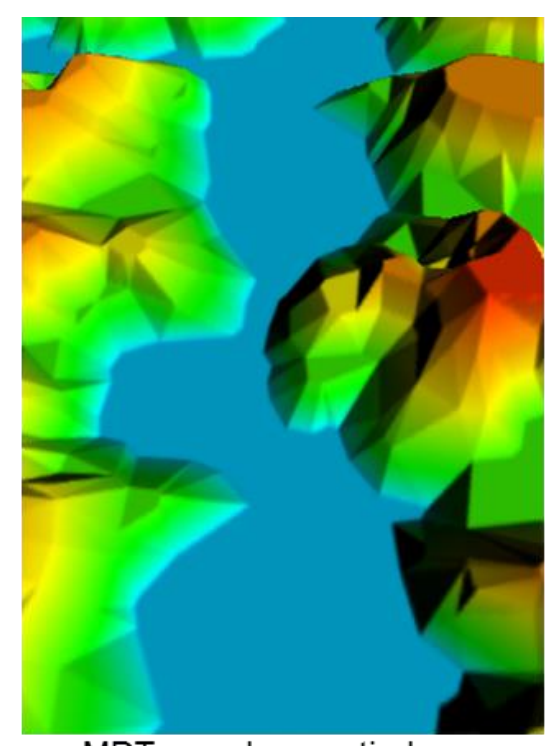

a. MDT gerado a partir das curvas de nível.

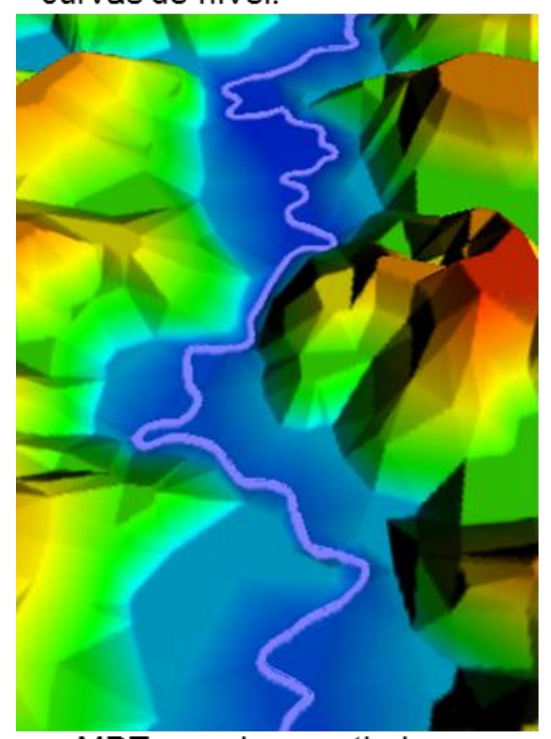

c. MDT gerado a partir das curvas de nível e da malha 3D ao longo do rio.

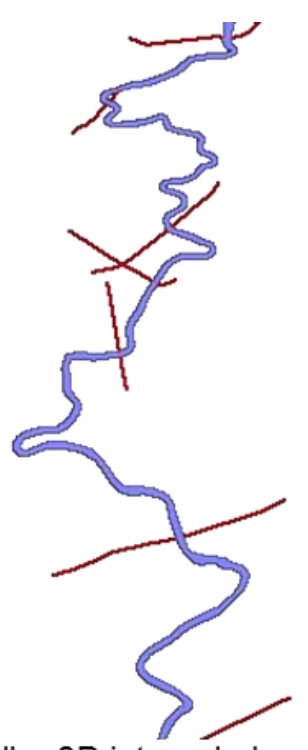

b. Malha 3D interpolada a partir das seções.

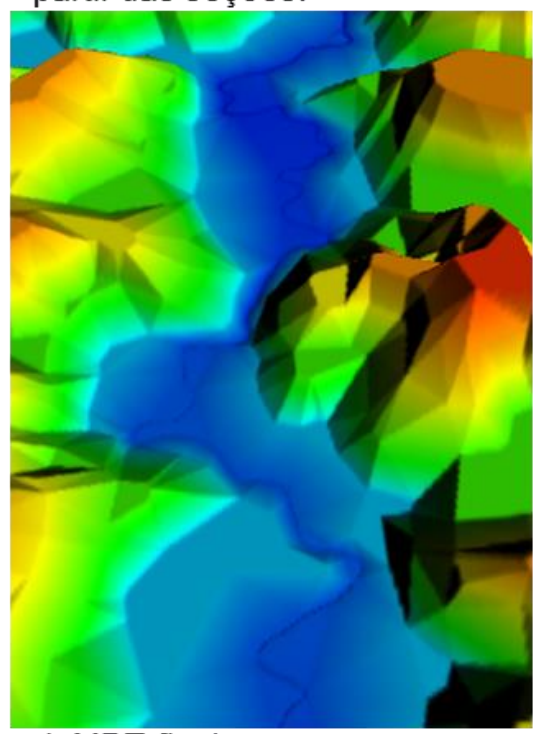

d. MDT final.
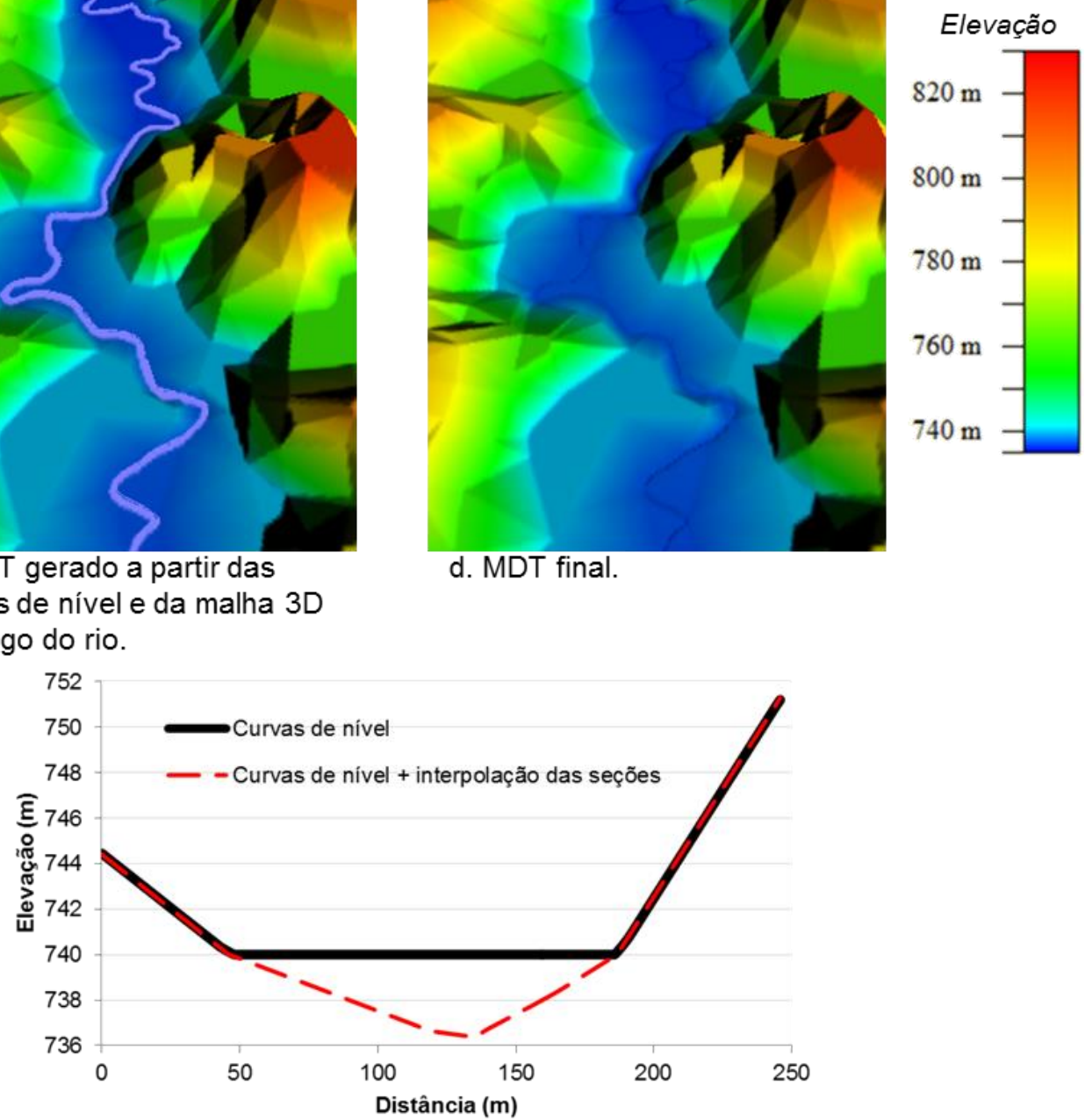

e. Comparação de um perfil gerado a partir da interpolação das seções topobatimétricas e curvas de nível com a interpolação apenas das curvas de nível.

Figura 24 - Aplicação da ferramenta de interpolação das seções topobatimétricas e detalhe do MDT resultante na calha do rio Atibaia. 


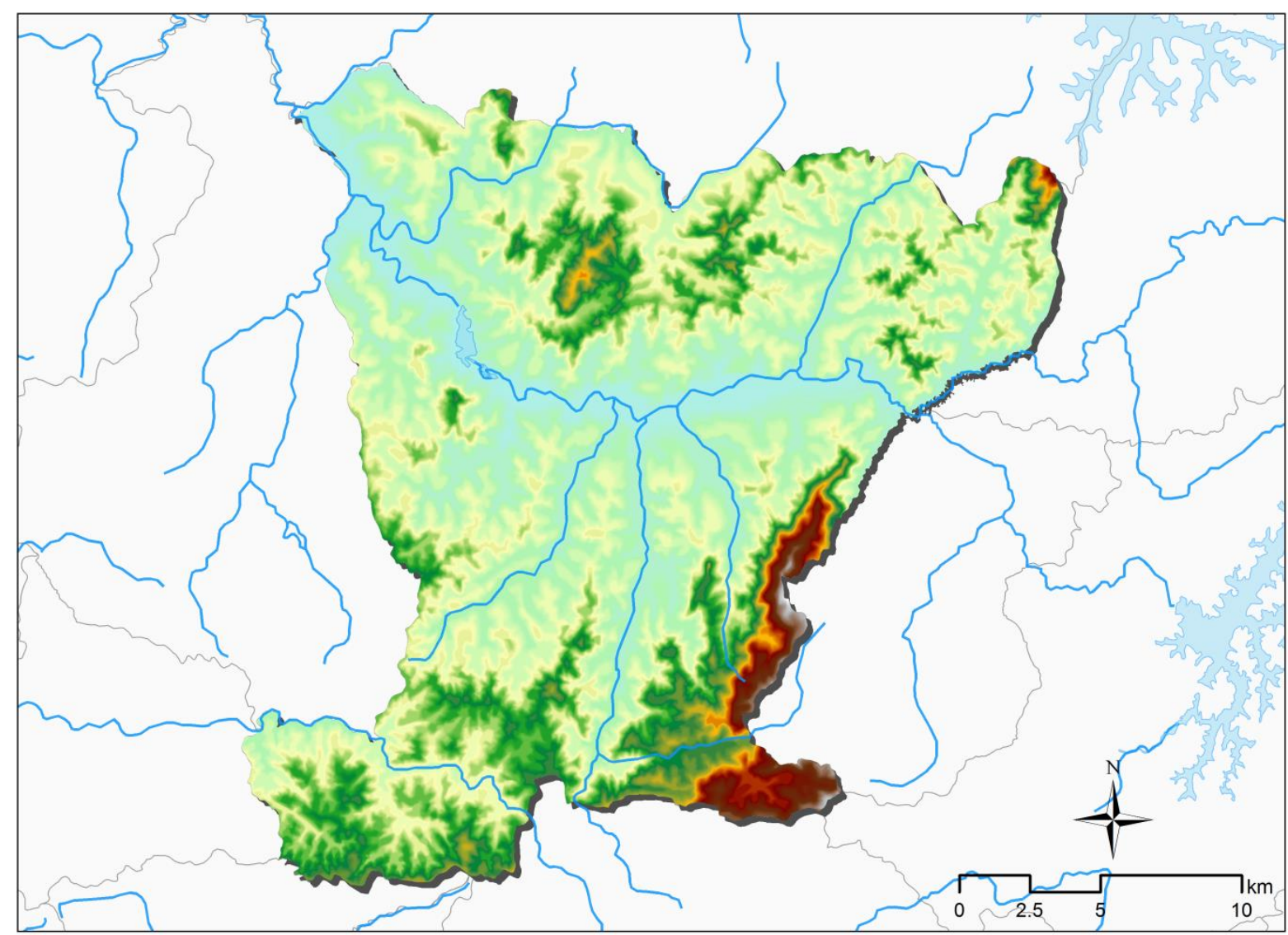

\section{Legenda}

Limites municipais Hidrografia principal

Represas principais
Elevação (m)

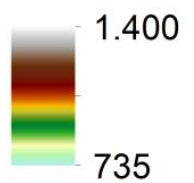

Figura 25 - MDT gerado a partir das curvas de nível e dos levantamentos topobatimétricos.

\subsubsection{Modelagem matemática}

Os dados de entrada do modelo foram obtidos dos levantamentos topobatimétricos, com exceção dos valores para o coeficiente de Manning, que foram estimados na etapa de calibração da modelagem. O principal parâmetro considerado para a calibração foi a altura da lâmina d'água na seção onde se encontra instalado o posto 54 do SAISP. A Figura 26 exibe a curva-chave do posto telemétrico e também a curva-chave final obtida a partir da calibração dos coeficientes de Manning no PCSWMM. Para se alcançar esta calibração, que se 
demonstrou bastante satisfatória na seção de controle mencionada, os coeficientes de Manning adotados foram 0,01 e 0,40, na seção principal e nas margens do rio, respectivamente. Estes valores foram adotados em todas as seções estudadas. Nota-se que o valor obtido para as áreas de várzea está coerente com a literatura, enquanto o valor estimado para a seção principal está um pouco abaixo dos valores mais comumente adotados em canais naturais.

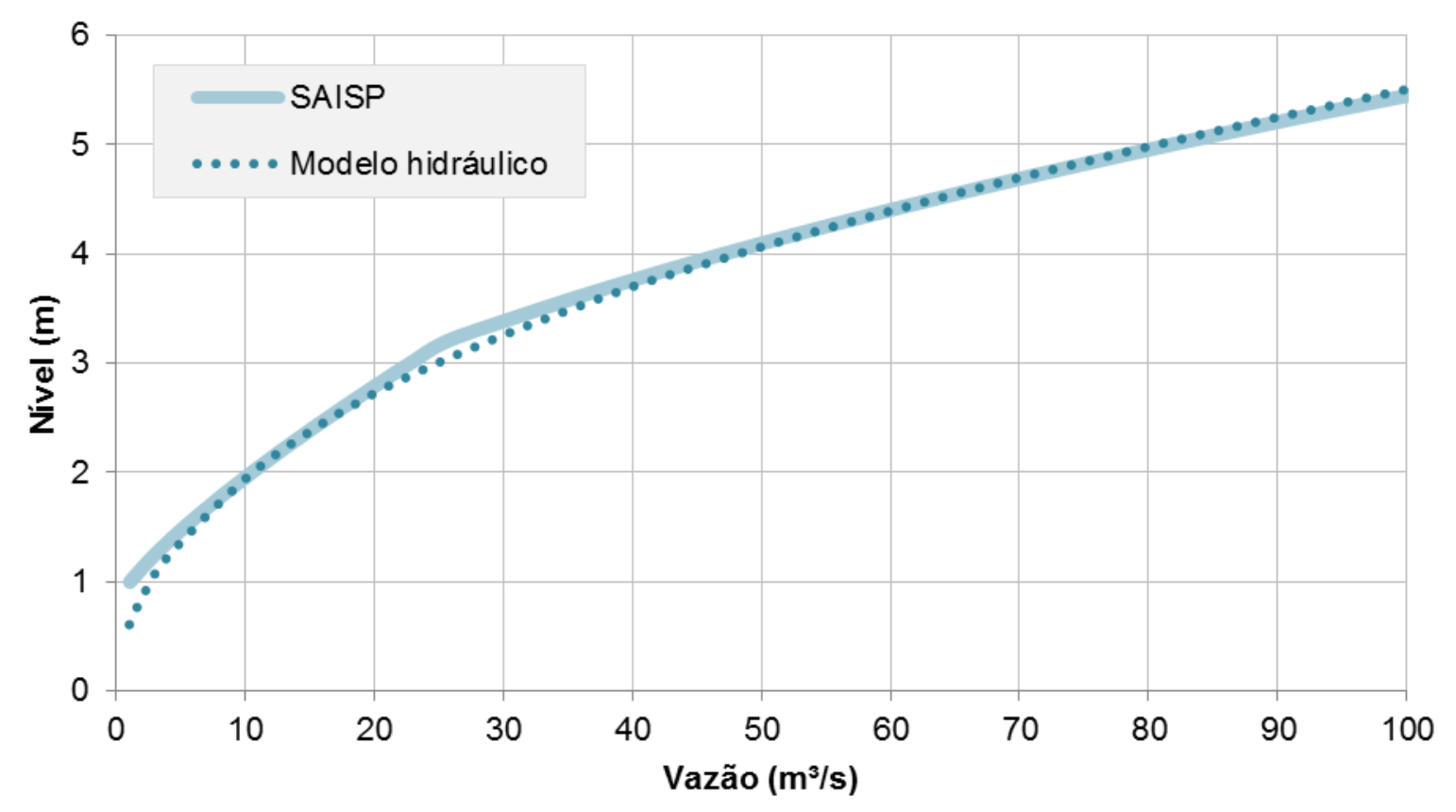

Figura 26 - Curva-chave estimada no ponto de controle.

Para a validação da calibração, a mancha gerada com a máxima vazão observada em janeiro de 2010 (64,48 m³/s) foi comparada aos pontos coletados em campo, que correspondem a locais inundados na cheia mencionada.

A mancha de inundação determinada para a vazão referente ao evento de janeiro de 2010 está apresentada na Figura 27, onde também estão representados os pontos aferidos em campo para o evento e os pontos compilados por DAEE (2010) para eventos ocorridos de dezembro de 2009 a fevereiro de 2010.

Através da análise da Figura 27, observa-se que, além de a modelagem hidráulica apresentar um comportamento bastante preciso em relação à curva-chave na seção de controle, a delimitação da mancha de inundação também se apresentou bastante satisfatória. No entanto, é possível observar a falta de aderência a alguns pontos observados; por exemplo, no trecho mais a montante, alguns locais destacados na visita de campo e no levantamento do DAEE (2010) não foram abrangidos na 
mancha estimada para o evento. Ainda a montante da região mais central de Atibaia, a situação se inverte e é possível observar que a mancha de inundação extrapola as localidades aferidas em campo. Esta imprecisão na mancha se deve especialmente à qualidade do MDT e, ainda que não comprometa os resultados de uma análise mais geral, sugere que um levantamento mais detalhado seja realizado na região, caso resultados mais refinados sejam almejados. 


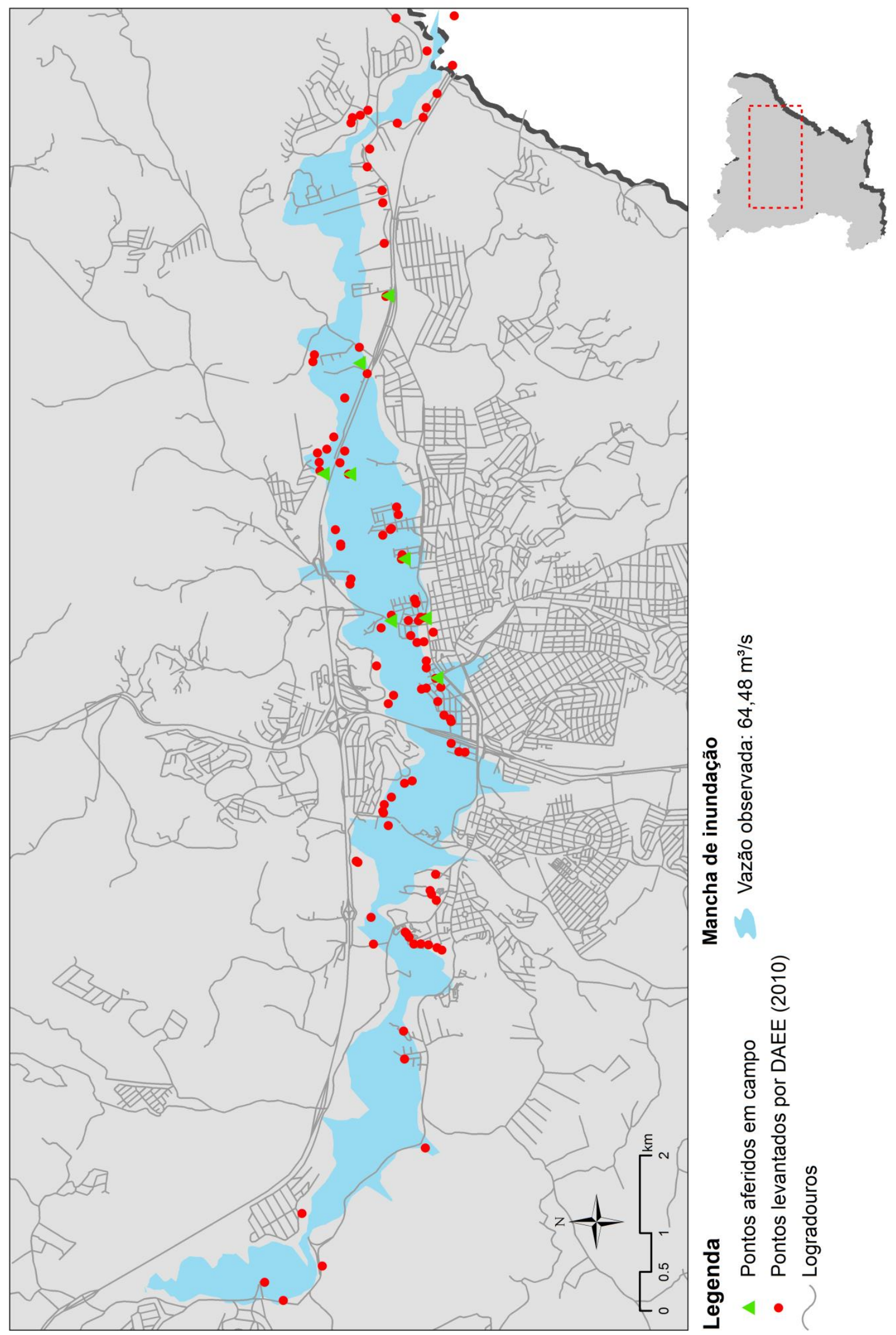

Figura 27 - Mancha de inundação e localização de pontos inundados observados na cidade de Atibaia para uma vazão de pico $64,48 \mathrm{~m}^{3} / \mathrm{s}$. 


\subsubsection{Manchas de inundação}

Para a estimativa das áreas inundáveis em Atibaia, foram simuladas as vazões para 25, 50 e 100 anos de período de retorno, mantendo-se os parâmetros calibrados apresentados anteriormente. Foram observadas, no entanto, diferenças bastante sutis - quase imperceptíveis na escala de análise adotada - entre os limites das manchas obtidas para vazões mais frequentes e aquelas geradas para períodos de retorno mais elevados, fato que se deve à topografia local. Isso comprova, mais uma vez, a suscetibilidade da região a vazões de baixa magnitude.

O fato de as manchas terem praticamente a mesma extensão não deve, no entanto, ocultar o fato de que, na medida em que se têm maiores vazões, a profundidade da lâmina d'água sofre um incremento considerável (vide Figura 26), o que implica, por sua vez, em maiores prejuízos e mais riscos à sociedade. Este tipo de análise requer modelos matemáticos que permitam a caracterização da mancha de inundação de acordo com os níveis d'água e representa uma limitação da modelagem realizada com o PCSWMM.

Para efeito de planejamento, será adotada a mancha obtida para o período de retorno de 100 anos, que, de acordo com o estudo hidrológico da série de dados observados, corresponde a uma vazão de $76,87 \mathrm{~m}^{3} / \mathrm{s}$ na região. O critério da cheia de 100 anos atende ao padrão internacional recomendado para o planejamento da macrodrenagem (SÃO PAULO, 2012). No entanto, quando for julgada interessante a divulgação das manchas de inundação à comunidade em geral, ou seja, ao público sem conhecimento técnico em hidrologia, devem-se buscar novas terminologias para expressar os critérios adotados, pois o conceito do "período de retorno" pode ser de difícil entendimento para o público leigo.

Conforme já mencionado, o mapeamento das áreas inundáveis deve ser capaz de distinguir faixas referentes ao risco de inundação, relacionada à zona de passagem das enchentes, que corresponde ao leito menor do rio, e à zona com restrições, equivalente à planície de inundação (leito maior). Esta última foi definida através de modelagem matemática. A delimitação da zona de passagem de enchente não é, no entanto, facilmente modelada devido, principalmente, às imprecisões do MDT e teve de ser estimada de forma empírica. 
Para cada seção topobatimétrica levantada, foi estimada a largura do leito menor, com base em análise visual. A largura entre cada seção foi interpolada ao longo do traçado do rio para que fosse delimitada a área de passagem das enchentes, antes da ocorrência das inundações, ou seja, antes do extravasamento. A Figura 28 ilustra a delimitação da zona para passagem das enchentes. Na sequência, a Figura 29 apresenta a mancha de inundação para o período de retorno de 100 anos e a delimitação da zona para passagem das enchentes.

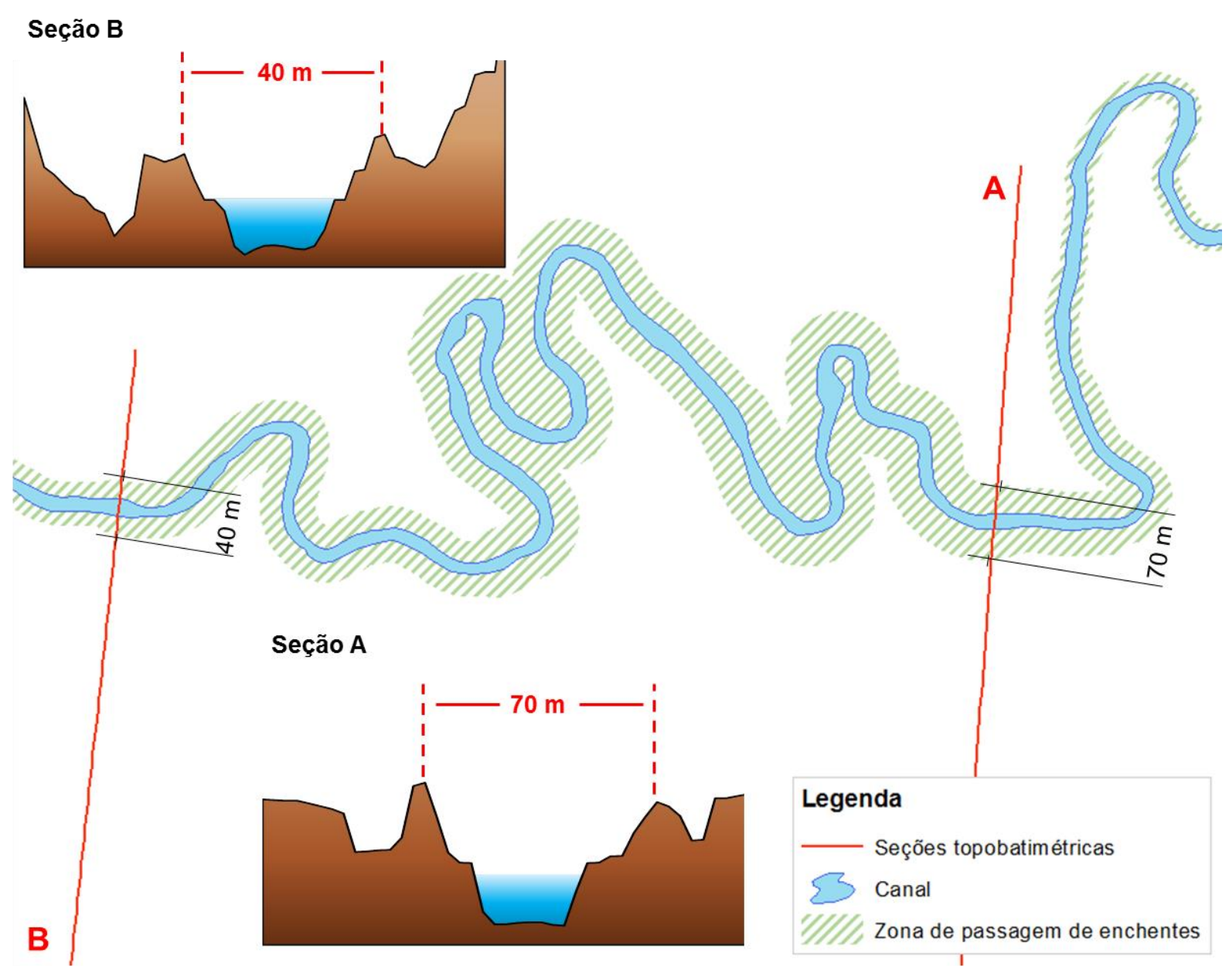

Figura 28 - Definição da zona de passagem de enchentes. 


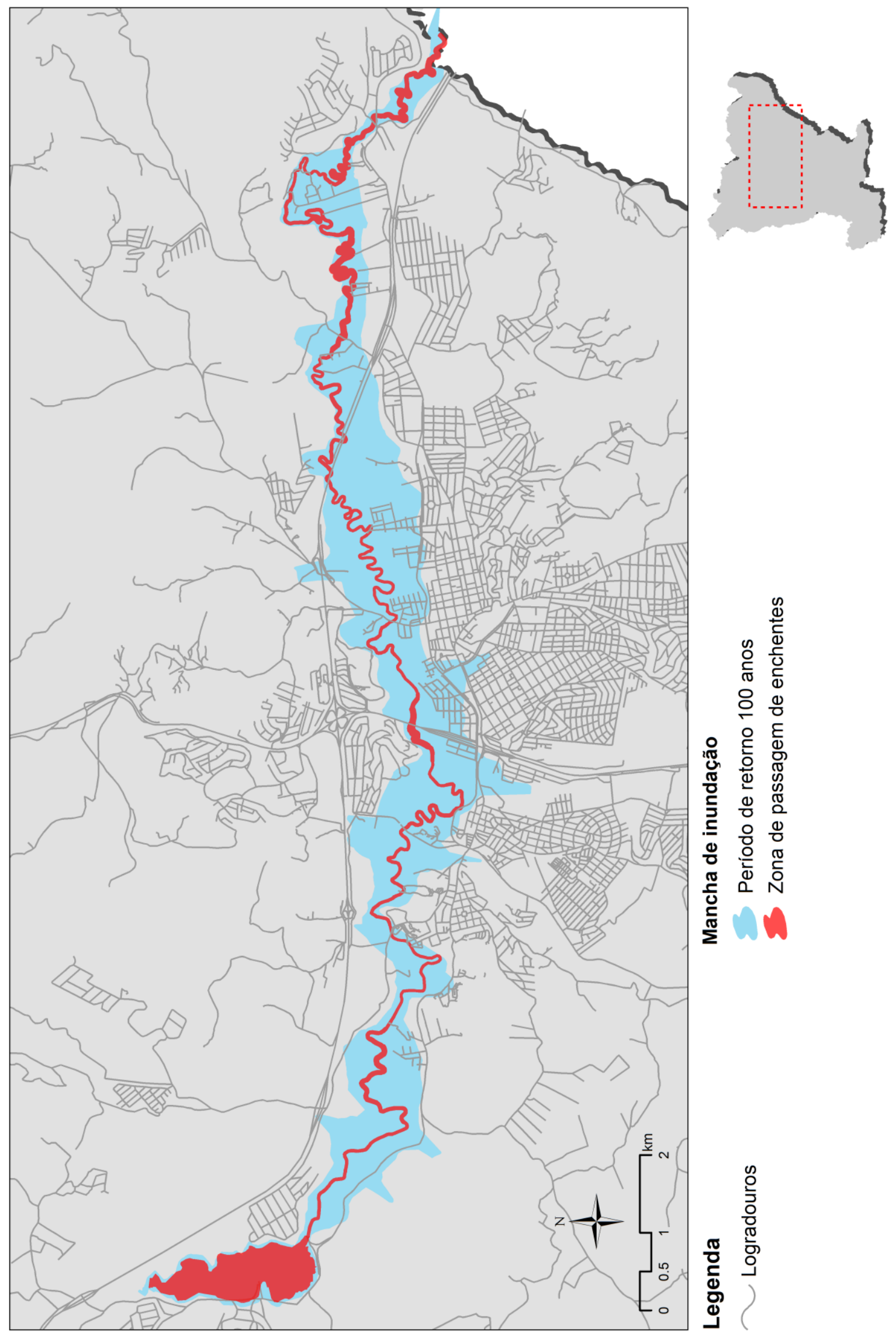

Figura 29 - Mancha de inundação para uma vazão de 100 de período de retorno e delimitação da zona de passagem de enchentes. 


\subsection{Uso e ocupação do solo}

\subsubsection{Análise crítica da legislação}

Embora a questão do uso do solo seja definida como municipal, a mesma deve ser considerada competência concorrente também entre Estado e União, que podem estabelecer normas para seu disciplinamento. A Lei Federal n‥ 6.766, de 19 de dezembro de 1979, dispõe sobre o Parcelamento do Solo Urbano, proibindo o parcelamento "em terrenos alagadiços e sujeitos a inundações, antes de tomadas as providências para assegurar o escoamento das águas”. A legislação mencionada e suas devidas regulamentações atribuem como competência do poder municipal a indicação de faixas sanitárias necessárias ao escoamento das águas pluviais e as chamadas faixas não edificáveis.

Dentre os princípios da Política Nacional do Meio Ambiente, instituída pela Lei no. 6.938, de 31 de agosto de 1981, podem ser destacados a racionalização do uso do solo e o zoneamento das atividades potencial ou efetivamente poluidoras. $O$ zoneamento ambiental surge novamente na Política Nacional de Meio Ambiente, como um de seus instrumentos, dentre os quais se destaca também a criação de espaços territoriais protegidos pelo poder público, como, por exemplo, áreas de proteção ambiental.

A Constituição Federal, instituída em 1988, dá continuidade à temática ambiental e determina como incumbência do poder público a definição de "espaços territoriais e seus componentes a serem especialmente protegidos, sendo a alteração e a supressão permitidas somente através de lei, vedada qualquer utilização que comprometa a integridade dos atributos que justifiquem sua proteção".

Em relação aos espaços urbanos, a Constituição prevê que a política de desenvolvimento e expansão deva ser executada pelo poder municipal, tendo como objetivo o ordenamento do desenvolvimento das funções sociais da cidade e a garantia ao bem-estar da população, sendo o plano diretor o instrumento básico desta política urbana, obrigatório para cidades com mais de vinte mil habitantes. A legislação determina que a política urbana municipal deva estabelecer as exigências 
fundamentais de ordenamento territorial para garantir que a propriedade urbana cumpra sua função social.

A Lei Federal №. 10.257, de 10 de julho de 2001, conhecida como Estatuto das Cidades, regulamenta a Constituição Federal na questão da política urbana, com base na cooperação dos setores público e privado e demais setores da sociedade. De acordo com o Estatuto, o ordenamento e o controle do uso e ocupação do solo deve evitar, entre outros aspectos, a exposição da população a risco de desastres, incluindo as inundações, sendo o plano diretor, o disciplinamento do uso e da ocupação do solo e o zoneamento ambiental alguns dos instrumentos previstos pela lei. A complementação desta lei, regida pela Lei oㅜ 12.608, de 10 de abril de 2012, estende a obrigatoriedade do plano diretor aos municípios incluídos no cadastro nacional de municípios com áreas suscetíveis à ocorrência de deslizamentos, inundações bruscas ou processos geológicos ou hidrológicos correlatos. Neste caso, o plano diretor de cada município pertencente a este cadastro deve conter:

- parâmetros de parcelamento, uso e ocupação do solo;

- mapeamento contendo as áreas suscetíveis à ocorrência de inundações bruscas;

- "planejamento de ações de intervenção preventiva e realocação de população de áreas de risco de desastre"; e

- "medidas de drenagem urbana necessárias à prevenção e à mitigação de impactos de desastres".

Cabe ao governo federal instituir o cadastramento mencionado, sendo que a inscrição no cadastro deve se dar por iniciativa do próprio município ou por indicação de outros entes federados. O município, por sua vez, deve fazer o mapeamento das áreas suscetíveis a inundações, elaborar carta geotécnica de aptidão à urbanização e adotar as providências para redução do risco, incluindo, quando necessário, a remoção de edificações e o reassentamento da população, além da criação de mecanismos de controle e fiscalização para evitar novas edificações em áreas propícias à ocorrência de tragédias naturais.

A integração do planejamento da ocupação à redução dos riscos dos desastres se torna clara na Lei ㄲo 12.608/2012, que além de regulamentar o Estatuto das Cidades na questão do parcelamento do solo urbano através do plano diretor, também dispõe sobre a Política Nacional de Proteção e Defesa Civil (PNPDEC), sendo que um dos objetivos da Política é "incorporar a redução do risco de desastre e as ações de proteção e defesa civil entre os elementos da gestão territorial e do 
planejamento das políticas setoriais". A legislação deixa claro mais uma vez que cabe ao município identificar e mapear as áreas de risco de desastres e promover a intervenção e evacuação da comunidade em áreas de alto risco, mas atribui à União e aos Estados a cooperação mútua e a articulação com os municípios no mapeamento das áreas de risco e outras atividades. Apesar disso, uma das diretrizes da PNPDEC é a adoção da bacia hidrográfica como unidade territorial de análise das ações de prevenção de desastres relacionados aos corpos d'água, em consonância com a Política Nacional de Recursos Hídricos (PNRH).

A PNRH, instituída pela Lei no. 9.433, de 8 de janeiro de 1997, define como um de seus objetivos "a prevenção e a defesa contra eventos hidrológicos críticos de origem natural ou decorrentes do uso inadequado dos recursos naturais". A legislação prevê também a articulação do gerenciamento dos recursos hídricos com a gestão do uso do solo, sendo que os Planos de Recursos Hídricos devem apresentar propostas de restrição do uso de determinadas áreas. Neste sentido, a lei determina que haja a integração das políticas municipais de saneamento, uso e ocupação do solo e meio ambiente às políticas federal e estadual de recursos hídricos. Assim, embora o domínio dos corpos d'água não seja do município, este exerce um importante papel para assegurar os princípios da PNRH (SÃO PAULO, 2012), ainda que a bacia hidrográfica seja a unidade territorial para sua implementação.

A Lei oㅜ 11.445, de 5 de janeiro de 2007, que estabelece as diretrizes nacionais para o saneamento básico, define como princípio fundamental às áreas urbanas a disponibilidade de serviços de drenagem e manejo de águas pluviais para garantir a saúde pública e a segurança da população e do patrimônio e adota, mais uma vez, a bacia hidrográfica como unidade territorial de referência para o planejamento.

Ainda que diversas leis definam a bacia hidrográfica como unidade de planejamento, como é o caso das políticas de recursos hídricos, defesa civil e saneamento básico, cabe ao município planejar o desenvolvimento das cidades. A efetividade dos instrumentos previstos nas diretrizes da legislação federal depende de sua inclusão nas políticas municipais, como é o caso do plano diretor. Este, para cumprir sua finalidade, depende de dois fatores: consistência em seu conteúdo e vontade política para sua execução (SÃO PAULO, 2012).

Outra legislação federal que busca disciplinar as diretrizes de ocupação nas margens de rios é a Lei no. 12.651, aprovada em 25 de maio de 2012, em 
substituição ao antigo Código Florestal, de 1965. Em meio a muitos pontos polêmicos, o texto institui como Área de Preservação Permanente (APP) as faixas marginais de largura variável de acordo com o porte do curso d'água. Por exemplo, define-se como APP as faixas marginais em largura mínima de 50 metros para cursos d'água naturais que tenham de 10 a 50 metros de largura, como é o caso do rio Atibaia, a partir da borda da calha por onde correm regularmente as águas do curso d'água durante o ano, chamado de leito regular; no caso de lagos e lagoas naturais em zonas urbanas, como a Represa da Usina, define-se como APP as áreas no seu entorno com largura mínima de 30 metros.

Uma APP corresponde a uma área protegida com diversas funções ambientais, como a preservação dos recursos hídricos, a proteção do solo e a garantia do bemestar da população. A lei federal permite $o$ acesso de pessoas e animais às APPs para obtenção de água ou para a realização de atividades de baixo impacto ambiental, sendo que a intervenção ou supressão da vegetação nativa só pode ser autorizada em casos excepcionais de utilidade pública, sem comprometer as funções ambientais destas áreas; ou seja, sem que haja risco de se agravarem os processos relacionados a inundações.

No caso de áreas urbanas, no entanto, os limites das APPs podem ser determinados no plano diretor ou outra legislação municipal de uso do solo, respeitados os limites mínimos e princípios definidos pela legislação federal, o que mantém coerência com os demais documentos citados, que atribuem ao município a definição da política de desenvolvimento urbano.

De acordo com Tucci e Bertoni (2003), a tendência é que os municípios introduzam nos Planos Diretores urbanos diretrizes de macrozoneamento incentivados pelos Estados. A própria Constituição do Estado de São Paulo, de 1989, prevê que este incentive os municípios na questão do zoneamento das áreas de inundação, incluindo restrições a usos incompatíveis em áreas frequentemente inundadas, assim como a implantação de sistemas de alerta e programas permanentes de combate às inundações.

A Política Estadual de Recursos Hídricos, instituída através da Lei №. 7.663, em 30 de dezembro de 1991, anterior à política nacional, determina a realização de programas em conjunto entre Estado e municípios para o zoneamento de áreas inundáveis e as respectivas restrições aos usos incompatíveis. Este instrumento também é objeto do Decreto ํo. 40.151, de 16 de junho de 1995, que dispõe sobre a 
reestruturação do Sistema Estadual de Defesa Civil. O decreto prevê novamente o incentivo aos municípios, por parte de órgãos estaduais, para a realização do zoneamento e a definição de restrições de uso do solo.

O mapeamento de vulnerabilidades e o zoneamento para disciplinar o uso e a ocupação do solo também são instrumentos da Política Estadual de Mudanças Climáticas (PEMC). A legislação define diretrizes para a adaptação aos impactos derivados de mudanças climáticas e a proteção e recuperação de áreas afetadas por eventos hidrológicos extremos, secas ou inundações. A PEMC reforça a necessidade da integração entre suas diretrizes e as demais políticas de recursos hídricos e de defesa civil.

O Programa Estadual de Prevenção de Desastres Naturais e de Redução de Riscos Geológicos, instituído através do Decreto nํ57.512, de 11 de novembro de 2011 , tem como um de seus objetivos promover o diagnóstico atualizado dos riscos de inundação, estabelecendo prioridades para o mapeamento das áreas de risco e desenvolvendo estratégias de planejamento do uso e ocupação do solo. $O$ mapeamento das áreas de risco consta nas ações definidas para o plano de trabalho do Programa Estadual, que prevê também mecanismos de incentivo aos municípios paulistas para que estes cumpram sua responsabilidade no planejamento e ordenamento territorial.

O arranjo da legislação brasileira deixa claro que o ordenamento do uso e ocupação do solo é atribuição do poder municipal. Entretanto, diversas leis nos âmbitos federal e estadual buscam contribuir com o tema. A questão da identificação das áreas com risco de inundação é retratada, direta ou indiretamente, como critério para este ordenamento territorial e deve ser considerada na elaboração de restrições a usos incompatíveis com áreas vulneráveis a estes eventos. Estas restrições, fundamentadas no zoneamento das áreas sujeitas a inundações ou outros desastres naturais, estão previstas na Lei Orgânica do município de Atibaia, revisada em 23 de fevereiro de 2012.

O "Plano Diretor da Estância de Atibaia 2006", aprovado pela Lei Complementar no 507, em vigência desde 5 de outubro de 2006, em total substituição ao anterior, elenca objetivos e diretrizes para o estabelecimento de normas e regulamentações necessárias para sua aplicação e também presume o cadastramento das áreas de ocorrência de enchentes, sem dar ênfase ao tema. 
O Plano Diretor define o conceito de partido urbanístico, que é configurado pelas diretrizes referentes ao assentamento urbano e rural, à organização espacial e ao uso e ocupação do solo. Entre os elementos de fundamentação do partido urbanístico destacam-se as destinações legais formais, que devem observar as restrições de mercado, ambientais ou de uso atual. Em relação às questões de caráter ambiental, o Plano identifica duas situações: (i) áreas de ocupação condicionada por restrições da ordem ambiental, inseridas em delimitações de Áreas de Proteção Ambiental (APAs), e (ii) áreas de ocupação não possível por restrições de ordem ambiental, inseridas em delimitações de APPs.

No que se refere às APPs, o Plano Diretor explicita a rigorosa observância das restrições que incidem sobre as áreas enquadradas nesta categoria. No entanto, a delimitação das APPs para o rio Atibaia, de acordo com os arquivos digitais disponibilizados pela prefeitura, define uma única faixa de 30 metros de largura ao longo do rio Atibaia e outra faixa com 50 metros de largura no entorno da represa da Usina, critérios que merecem revisão. Conforme já mencionado, de acordo com a legislação vigente que define as Áreas de Preservação Permanente, aprovada em 2012, as APPs ao redor do rio Atibaia são definidas como as faixas marginais de, pelo menos, 50 metros de largura de cada lado, uma vez que a largura do rio Atibaia varia entre 10 e 50 metros. Ao redor da represa da Usina, no entanto, a largura da APP pode ser de apenas 30 metros, por se tratar de zona urbana.

O Plano Diretor prevê ainda a instituição da APA Várzeas do Atibaia, na área definida como Área de Interesse Ambiental Relevante (AIAR), definida pela antiga lei de ordenamento do uso e ocupação do solo. O estabelecimento da APA é uma das diretrizes da Política de Meio Ambiente da Estância de Atibaia, também criada pela Lei Complementar no. 507/2006, que prevê ainda tratamento especial aos espaços já urbanizados presentes nesta área.

O ordenamento urbanístico e ambiental em vigor no município é dado através do Código de Urbanismo e Meio Ambiente (CURMA), instituído por meio da Lei Complementar ㄲo. 580, de 19 de dezembro de 2008. O CURMA tem o objetivo de instrumentalizar a implantação das diretrizes e objetivos expressos no Plano Diretor e estabelece diretrizes e critérios quanto ao uso e ocupação do solo, instituindo 13 zonas de ocupação, das categorias Residenciais, Mistas, Exclusivamente Econômicas e Especiais, às quais são propostas características e tendências de 
ocupação. As características e finalidades de cada zona estão apresentadas no Apêndice A - Principais referências legislativas.

Dentre as características e finalidades de cada zona definida pelo Código, não constam, no entanto, áreas de amortecimento das cheias ou de ocupação restrita devido à ocorrência de inundações. As condições exigidas para empreendimentos localizados em áreas de solos instáveis e alagadiços englobam apenas estudos de sondagens, projeto de drenagem a fim de evitar erosão e assoreamento e proteção dos taludes. Além disso, os critérios para o enquadramento de uma área alagadiça não é determinado. As regras e restrições contra ocupações nas várzeas e encostas se tornam aplicáveis apenas em áreas enquadradas como Áreas de Preservação Permanente (APP), em áreas tombadas ou, ainda, em outras categorias de áreas de conservação previstas pela Lei Federal ํo. 9.985, de 18 de julho de 2000, que rege o Sistema Nacional de Unidades de Conservação (SNUC), estando as APAs Usina e Várzea do Atibaia localizadas na região da várzea do rio Atibaia, além da APA do Sistema Cantareira, que abrange todo o município. As restrições relativas a estas áreas estão definidas no âmbito de cada legislação pertinente, sem nenhuma repercussão nas diretrizes do zoneamento do CURMA.

A Área de Proteção Ambiental Várzea do Atibaia foi instituída pela Lei Municipal №. 3.705, em 19 de dezembro de 2008 - mesma data em que foi aprovado o Código de Urbanismo e Meio Ambiente - com o objetivo de assegurar condições adequadas de espraiamento às vazões correspondentes aos períodos de cheia do rio Atibaia, além de visar à qualidade ambiental e paisagística da cidade e a preservação da biodiversidade existente. A legislação prevê a elaboração de um Plano de Manejo que contenha necessariamente normas referentes ao uso e ocupação do solo na APA, em consonância com o zoneamento ecológico-econômico da área, além de diretrizes para a constituição de um parque linear.

A legislação que instituiu a APA Várzeas do Atibaia determina um zoneamento geral preliminar que define as Áreas de Proteção Integral (API) como aquelas entre as margens do rio Atibaia e seus afluentes e a linha de cota 742,50 metros do nível do mar e as Áreas de Transição (ATR), sendo as demais áreas. O Plano de Manejo deve conter o zoneamento ecológico-econômico da área, em substituição ou complementação ao zoneamento preliminar, e as normas referentes ao uso e à ocupação das áreas que integram a APA, em conformidade com este zoneamento, incluindo as condições específicas para a constituição de parque urbano linear 
voltado ao lazer e à recreação. A legislação municipal também faz referência à APA da Usina, instituída pela Lei Estadual oㅜ 5.280, de 4 de setembro de 1986, que também ainda não contém Plano de Manejo, apesar de ter sido instituída há quase 30 anos.

É possível observar que o zoneamento de áreas inundáveis, apesar de previsto por diversas leis, não é objeto dos instrumentos municipais que regulamentam a ocupação do solo. A legislação dá indícios de promover restrições neste sentido, com a instituição da Área de Proteção Ambiental, mas ainda é falha, no sentido que o Plano de Manejo, que teria 24 meses para ser elaborado, ainda não foi instituído, sendo que o prazo para sua execução venceu em dezembro de 2010.

Por outro lado, a análise das leis estaduais e federais indica que a regulamentação do uso do solo seja definida explicitamente através do plano diretor, e não através de outro instrumento. No caso específico do mapeamento de áreas inundáveis, a Lei Federal №. 12.608/2012 obriga que este esteja incluído no plano diretor de cada município pertencente ao cadastro nacional de municípios com áreas suscetíveis à ocorrência de deslizamentos, inundações bruscas ou processos geológicos ou hidrológicos correlatos. Embora o cadastro seja outro instrumento ainda não finalizado, a legislação federal já indica a tendência da obrigatoriedade de inclusão do mapeamento das áreas de inundação no plano diretor. Com esta tendência, espera-se que sejam também estabelecidos os critérios para a delimitação das áreas inundáveis, para que haja uma uniformização dos métodos utilizados para a elaboração dos estudos e planos propostos pelos municípios, uma vez que a política de ordenamento territorial deve observar as definições federais, estaduais e da bacia hidrográfica onde o município está inserido.

\subsubsection{Situação atual}

As análises hidrológica e hidráulica realizadas permitiram avaliar a extensão da zona inundável para o período de retorno de 100 anos. A interpretação do risco depende da sobreposição dos limites das áreas inundáveis aos diferentes aspectos da ocupação local e das restrições aplicadas pela legislação vigente. As interfaces de planejamento que podem ser analisadas de acordo com as áreas inundáveis são 
diversas, com destaque aos limites físicos e políticos aqui apresentados: áreas de preservação permanente, áreas de proteção ambiental, setores censitários e zoneamento urbanístico definido no Código de Urbanismo e Meio Ambiente do município.

A Figura 30 exibe a mancha de inundação, considerando os limites definidos para a zona para a passagem das enchentes e para a zona com restrições, em comparação às áreas de preservação e proteção definidas em lei para a várzea do rio, a saber:

- Área de Preservação Permanente (APP), definida no âmbito do novo Código Florestal como as faixas marginais às bordas da calha do leito regular com largura de 50 metros e 30 metros para o entorno da represa da Usina;

- Área de Proteção Ambiental (APAs) Várzea do Atibaia e APA da Usina, cuja delimitação foi disponibilizada através do banco de dados do Plano Diretor do município.

Através da análise da Figura 30, é possível estabelecer uma relação entre as categorias de unidades de proteção e as zonas definidas como passagem de enchentes ou como zonas com restrições à ocupação. A zona para passagem das enchentes está compreendida nos limites da APP delimitada para o rio Atibaia, sendo que as finalidades da APP envolvem a mitigação de risco de enchentes e a proteção das várzeas. A Lei №. 12.651/2012 define, ainda, que o acesso a pessoas e animais às APPs deve ter como finalidade de obtenção de água ou realização de atividades de baixo impacto ambiental. Assim, estima-se que as definições da ocupação previstas pela legislação que institui as Áreas de Preservação Permanente sejam suficientes para atender às sugestões de uso e ocupação do solo nas zonas para passagem das enchentes. As regulamentações previstas nas Áreas de Preservação Permanente não contemplam, no entanto, toda a extensão da mancha de inundação, que deve, então, ser analisada de acordo com os outros instrumentos de planejamento.

As áreas inundadas estão quase integralmente compreendidas dentro da APA Várzeas do Atibaia, sendo que um dos objetivos desta área de proteção é assegurar as condições de espraiamento adequadas ao regime de cheias, prevenindo o uso inadequado destas áreas a partir de seu zoneamento ecológico-econômico, que deve estar contido no Plano de Manejo da APA. Os limites da APA da Usina também contemplam as áreas inundadas no trecho simulado. Contudo, o zoneamento 
mencionado e as restrições pertinentes a estas áreas não estão definidos, uma vez que os respectivos Planos de Manejo ainda não foram instituídos. É desejável que a elaboração destes Planos, os quais devem prever também a constituição de parque urbano linear voltado ao lazer e à recreação, leve em conta os limites da mancha de inundação para que critérios mais rigorosos possam ser adotados dentro destas áreas. Ao mesmo tempo, os documentos devem considerar as definições previstas pela legislação que rege as APPs, sendo que estas não precisam ser reproduzidas, mas devem ser acatadas e complementadas, se necessário. 


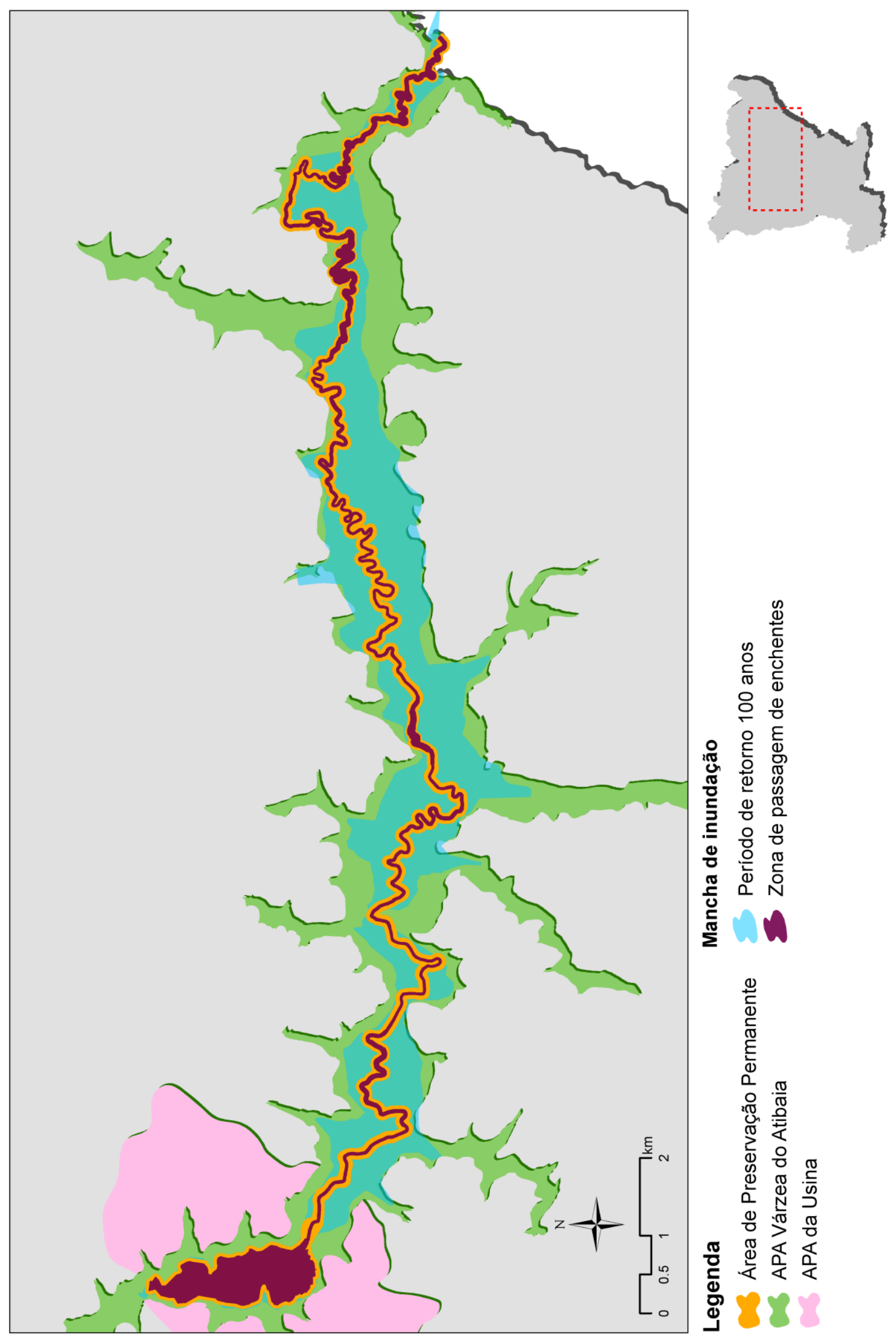

Figura 30 - Mancha de inundação e áreas de preservação e proteção. 
Outro importante instrumento de uso e ocupação do solo no município é o Código de Urbanismo e Meio Ambiente, que define seu ordenamento urbanístico e ambiental. A Figura 31 exibe a mancha de inundação sobre o zoneamento definido de acordo com o CURMA.

Nota-se que as áreas inundáveis abrangem todos os tipos de zona, com exceção das zonas Exclusivamente Econômica 1 e Especial 4. De acordo com as finalidades definidas no Código para cada zona, a questão das inundações é ignorada; ou seja, a ocupação destas áreas de risco tem respaldo na legislação vigente, sendo que as finalidades de algumas zonas apresentam, inclusive, características residenciais e de alta densidade populacional. Neste sentido, a Figura 32 exibe a densidade populacional estimada a partir dos dados censitários do IBGE, para cada setor.

Para a estimativa do risco, a parcela da área inundada em cada setor censitário foi relacionada à sua densidade demográfica, de acordo com os critérios apresentados na Tabela 10. Para a definição de tais critérios, os valores de densidade populacional para cada setor atingido pela inundação estimada foram distribuídos em 5 faixas, de acordo com os percentis 20, 40, 60 e 80. As faixas de área inundada foram distribuídas de maneira uniforme, com exceção da primeira (inferior a 5\% de área inundada), que busca enquadrar áreas inundadas pouco significativas, com risco baixo ou muito baixo.

O cruzamento destes critérios aos parâmetros estimados em cada setor censitário deu origem ao mapa de risco, apresentado na Figura 33. Estes resultados também estão apresentados na Tabela 11, que contém apenas os distritos atingidos pelas inundações, considerando o período de retorno de 100 anos.

Tabela 10 - Critérios para definição do risco.

\begin{tabular}{|c|c|c|c|c|c|c|}
\hline \multirow{2}{*}{$\begin{array}{l}\text { Densidade } \\
\text { populacional } \\
\text { (hab./km²) }\end{array}$} & \multicolumn{6}{|c|}{ Área inundada (\%) } \\
\hline & $<5,0$ & $5,0-19,9$ & $20,0-39,9$ & $40,0-59,9$ & $60,0-79,9$ & $80,0-100,0$ \\
\hline$<39,8$ & $\begin{array}{l}\text { MUITO } \\
\text { BAIXO }\end{array}$ & $\begin{array}{l}\text { MUITO } \\
\text { BAIXO }\end{array}$ & $\begin{array}{l}\text { MUITO } \\
\text { BAIXO }\end{array}$ & BAIXO & MÉDIO & MÉDIO \\
\hline $39,8-173,9$ & $\begin{array}{l}\text { MUITO } \\
\text { BAIXO }\end{array}$ & $\begin{array}{l}\text { MUITO } \\
\text { BAIXO }\end{array}$ & BAIXO & MÉDIO & MÉDIO & MÉDIO \\
\hline $174,0-956,6$ & $\begin{array}{l}\text { MUITO } \\
\text { BAIXO }\end{array}$ & BAIXO & BAIXO & MÉDIO & ALTO & ALTO \\
\hline $956,7-4.088,8$ & $\begin{array}{l}\text { MUITO } \\
\text { BAIXO }\end{array}$ & MÉDIO & MÉDIO & ALTO & ALTO & $\begin{array}{l}\text { MUITO } \\
\text { ALTO }\end{array}$ \\
\hline$>4.088,8$ & BAIXO & MÉDIO & ALTO & ALTO & $\begin{array}{l}\text { MUITO } \\
\text { ALTO }\end{array}$ & $\begin{array}{l}\text { MUITO } \\
\text { ALTO }\end{array}$ \\
\hline
\end{tabular}




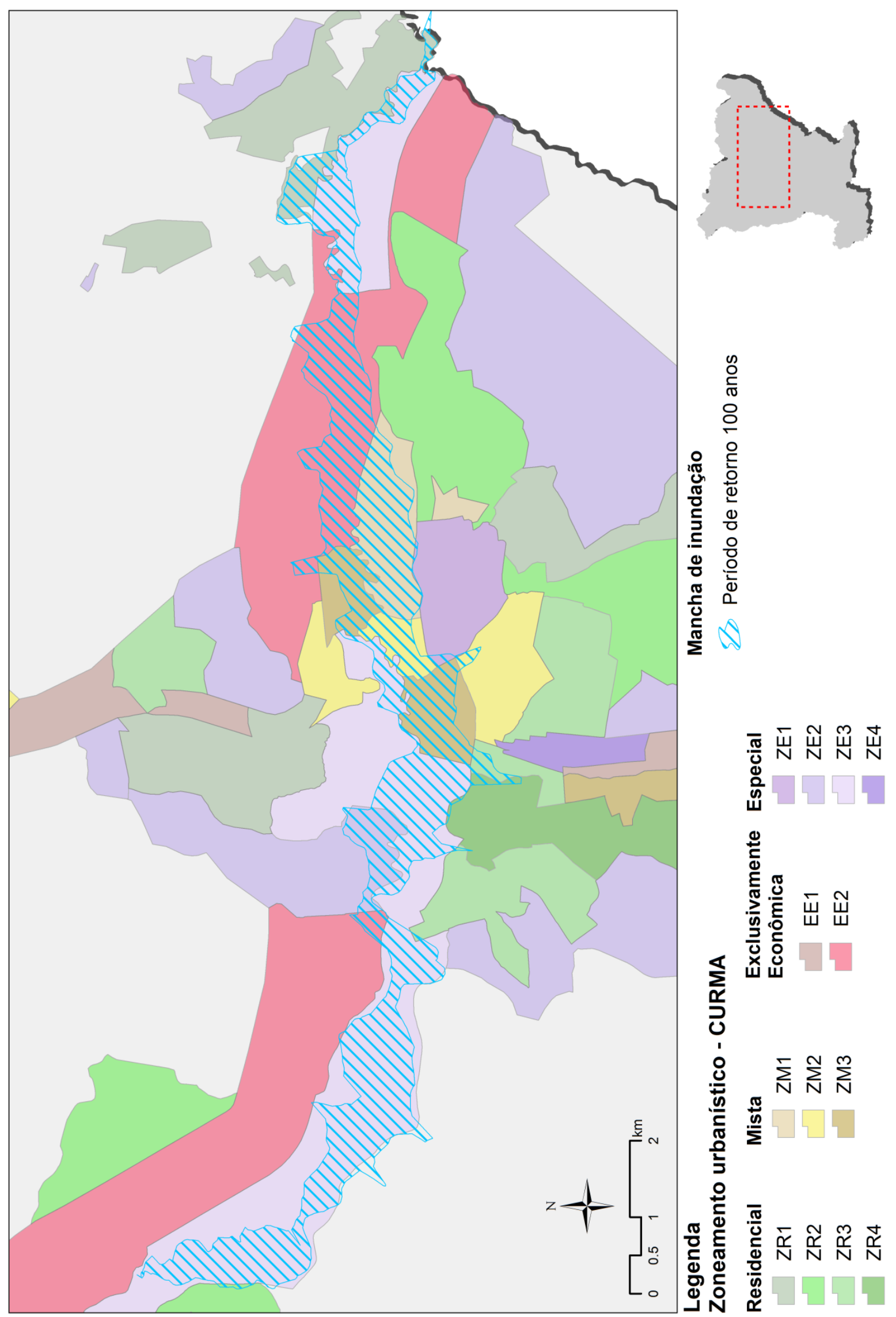

Figura 31 - Mancha de inundação e zoneamento urbanístico. 


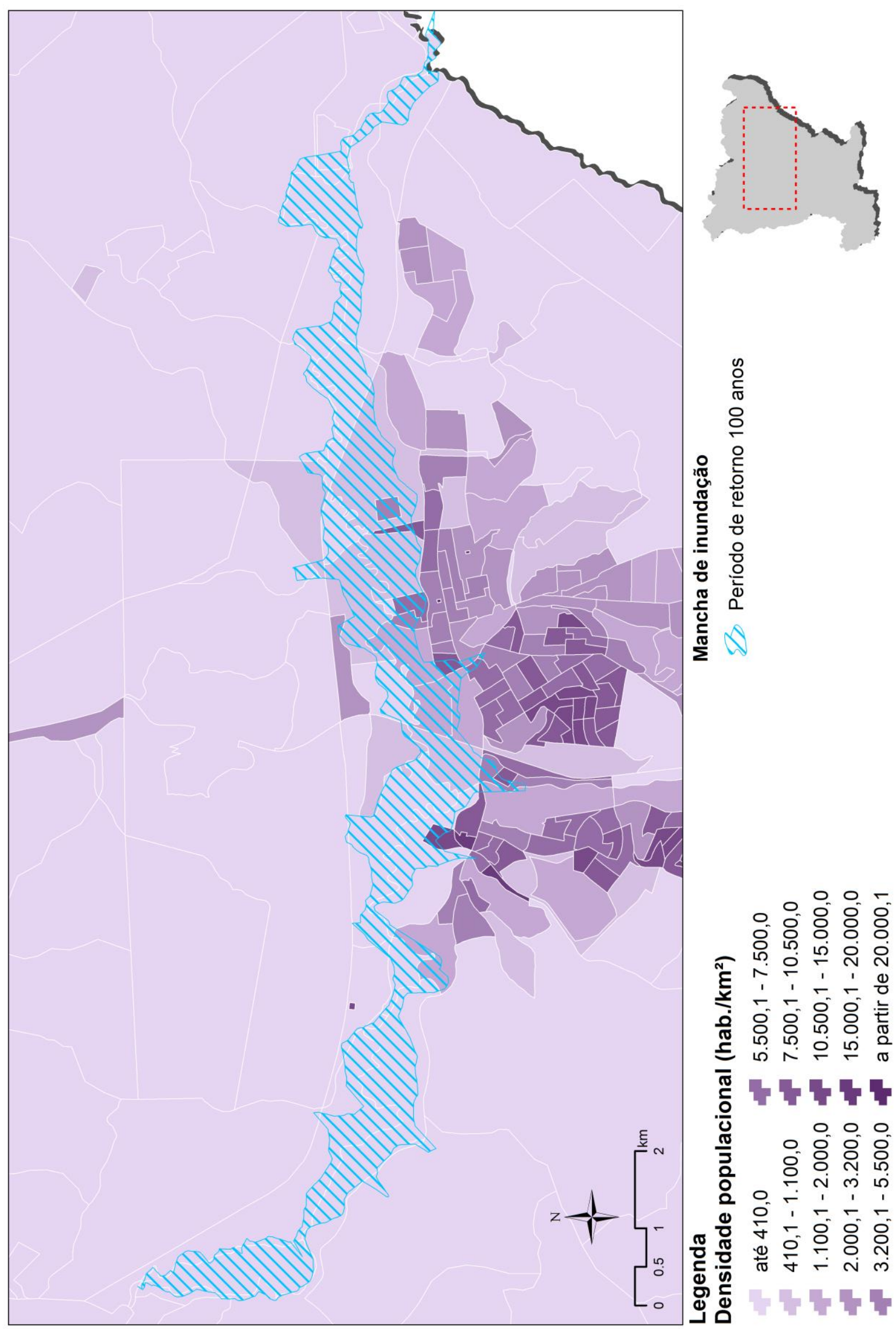

Figura 32 - Mancha de inundação e densidade populacional. 


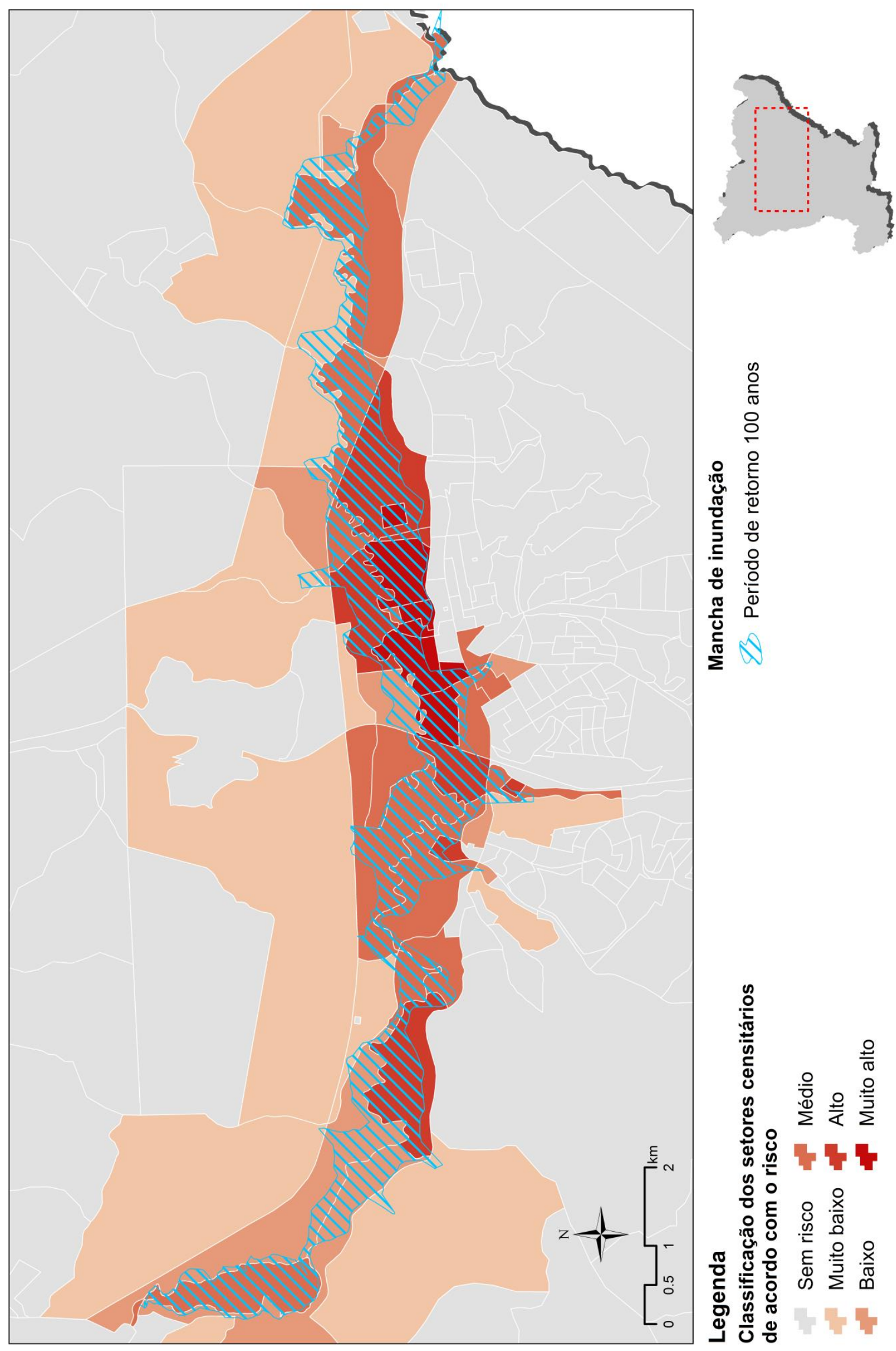

Figura 33 - Mapa de risco. 
Tabela 11 - Estimativa do risco por setor censitário inundado.

\begin{tabular}{|c|c|c|c|c|c|c|}
\hline \multirow[t]{2}{*}{ SETOR } & \multirow{2}{*}{$\begin{array}{l}\text { ÁREA TOTAL } \\
\left(\mathrm{KM}^{2}\right)\end{array}$} & \multirow{2}{*}{$\begin{array}{l}\text { POPULAÇÃo } \\
\text { RESIDENTE } \\
\text { (HAB.) })^{\mathrm{a}}\end{array}$} & \multirow{2}{*}{$\begin{array}{c}\text { DENSIDADE } \\
\text { POPULACIONAL } \\
(\text { HAB./KM²) }\end{array}$} & \multicolumn{2}{|c|}{$\begin{array}{l}\text { ÁREA INUNDADA } \\
\text { TR }=100 \text { ANOS }\end{array}$} & \multirow[t]{2}{*}{ Risco } \\
\hline & & & & $\left(\mathrm{KM}^{2}\right)$ & $(\%)$ & \\
\hline 05000010 & 0,136 & 380 & 2790,1 & 0,016 & $11,6 \%$ & MÉDIO \\
\hline 05000012 & 0,074 & 382 & 5137,7 & 0,057 & $76,5 \%$ & MUITO ALTO \\
\hline 05000027 & 0,123 & 607 & 4939,6 & 0,004 & $3,5 \%$ & BAIXO \\
\hline 05000028 & 0,119 & 699 & 5883,2 & 0,017 & $14,1 \%$ & MÉDIO \\
\hline 05000029 & 0,082 & 681 & 8343,6 & 0,049 & $60,4 \%$ & MUITO ALTO \\
\hline 05000030 & 0,437 & 717 & 1642,2 & 0,362 & $82,9 \%$ & MUITO ALTO \\
\hline 05000031 & 0,117 & 846 & 7200,3 & 0,098 & $83,4 \%$ & MUITO ALTO \\
\hline 05000032 & 0,540 & 517 & 956,6 & 0,513 & $95,0 \%$ & MUITO ALTO \\
\hline 05000033 & 0,070 & 534 & 7616,6 & 0,040 & $57,0 \%$ & ALTO \\
\hline 05000046 & 0,354 & 619 & 1747,9 & 0,114 & $32,3 \%$ & MÉDIO \\
\hline 05000047 & 0,450 & 419 & 930,8 & 0,437 & $97,1 \%$ & ALTO \\
\hline 05000048 & 0,546 & 585 & 1070,7 & 0,065 & $12,0 \%$ & MÉDIO \\
\hline 05000049 & 0,820 & 574 & 700,4 & 0,634 & $77,4 \%$ & ALTO \\
\hline 05000050 & 0,304 & 966 & 3175,1 & 0,008 & $2,6 \%$ & MUITO BAIXO \\
\hline 05000052 & 2,618 & 256 & 97,8 & 0,004 & $0,2 \%$ & MUITO BAIXO \\
\hline 05000053 & 0,302 & 12 & 39,7 & 0,279 & $92,6 \%$ & MÉDIO \\
\hline 05000058 & 2,148 & 535 & 249,0 & 0,936 & $43,6 \%$ & MÉDIO \\
\hline 05000081 & 0,138 & 1106 & 8030,8 & 0,006 & $4,1 \%$ & BAIXO \\
\hline 05000082 & 0,108 & 1241 & 11516,5 & 0,057 & $52,7 \%$ & ALTO \\
\hline 05000083 & 0,614 & 14 & 22,8 & 0,046 & $7,5 \%$ & MUITO BAIXO \\
\hline 05000085 & 7,836 & 334 & 42,6 & 0,006 & $0,1 \%$ & MUITO BAIXO \\
\hline 05000095 & 0,737 & 866 & 1175,7 & 0,033 & $4,5 \%$ & MUITO BAIXO \\
\hline 05000101 & 0,039 & 264 & 6685,1 & 0,000 & $0,7 \%$ & BAIXO \\
\hline 05000102 & 0,440 & 704 & 1599,5 & 0,001 & $0,2 \%$ & MUITO BAIXO \\
\hline 05000104 & 0,449 & 624 & 1390,2 & 0,163 & $36,2 \%$ & MÉDIO \\
\hline 05000105 & 2,168 & 291 & 134,2 & 0,649 & $30,0 \%$ & BAIXO \\
\hline 05000106 & 2,340 & 235 & 100,4 & 0,923 & $39,4 \%$ & BAIXO \\
\hline 05000107 & 0,999 & 0 & 0,0 & 0,940 & $94,2 \%$ & MÉDIO \\
\hline 05000108 & 4,918 & 416 & 84,6 & 0,004 & $0,1 \%$ & MUITO BAIXO \\
\hline 05000143 & 0,811 & 768 & 946,9 & 0,083 & $10,3 \%$ & BAIXO \\
\hline 05000145 & 0,232 & 758 & 3271,6 & 0,087 & $37,7 \%$ & MÉDIO \\
\hline 05000173 & 0,245 & 85 & 347,6 & 0,096 & $39,1 \%$ & BAIXO \\
\hline 05000177 & 5,218 & 82 & 15,7 & 0,055 & $1,1 \%$ & MUITO BAIXO \\
\hline 05000207 & 0,029 & 0 & 0,0 & 0,029 & $100,0 \%$ & MÉDIO \\
\hline 05000209 & 0,034 & 6 & 173,9 & 0,010 & $28,5 \%$ & BAIXO \\
\hline 05000214 & 0,318 & 465 & 1461,1 & 0,318 & $100,0 \%$ & MUITO ALTO \\
\hline 05000215 & 0,476 & 16 & 33,6 & 0,282 & $59,2 \%$ & BAIXO \\
\hline 05000217 & 0,982 & 199 & 202,6 & 0,047 & $4,8 \%$ & MUITO BAIXO \\
\hline 05000218 & 1,391 & 600 & 431,4 & 0,990 & $71,1 \%$ & ALTO \\
\hline 05000219 & 0,083 & 338 & 4088,8 & 0,083 & $100,0 \%$ & MUITO ALTO \\
\hline 05000226 & 0,836 & 184 & 220,1 & 0,209 & $25,0 \%$ & BAIXO \\
\hline
\end{tabular}


Tabela 11 - Estimativa do risco por setor censitário inundado. (conclusão)

\begin{tabular}{|c|c|c|c|c|c|c|}
\hline \multirow[t]{2}{*}{ SETOR } & \multirow{2}{*}{$\begin{array}{l}\text { ÁREA TOTAL } \\
\left(\mathrm{KM}^{2}\right)\end{array}$} & \multirow{2}{*}{$\begin{array}{l}\text { POPULAÇÃo } \\
\text { RESIDENTE } \\
\text { (HAB.)! }\end{array}$} & \multirow{2}{*}{$\begin{array}{c}\text { DENSIDADE } \\
\text { POPULACIONAL } \\
\text { (HAB./KM²) }\end{array}$} & \multicolumn{2}{|c|}{$\begin{array}{l}\text { ÁREA INUNDADA } \\
\text { TR }=100 \text { ANOS }\end{array}$} & \multirow[t]{2}{*}{ Rısco } \\
\hline & & & & $\left(\mathrm{KM}^{2}\right)$ & (\%) & \\
\hline 05000232 & 1,755 & 228 & 129,9 & 1,119 & $63,8 \%$ & MÉDIO \\
\hline 05000233 & 1,118 & 205 & 183,3 & 0,590 & $52,7 \%$ & MÉDIO \\
\hline 05000244 & 0,267 & 46 & 172,3 & 0,229 & $85,8 \%$ & MÉDIO \\
\hline 05000245 & 1,155 & 213 & 184,4 & 0,825 & $71,4 \%$ & ALTO \\
\hline 05000281 & 0,678 & 14 & 20,7 & 0,636 & $93,8 \%$ & MÉDIO \\
\hline 05000283 & 0,044 & 397 & 9068,9 & 0,015 & $33,3 \%$ & ALTO \\
\hline 05000292 & 1,713 & 211 & 123,2 & 0,002 & $0,1 \%$ & MUITO BAIXO \\
\hline 05000316 & 0,153 & 14 & 91,3 & 0,089 & $58,1 \%$ & MÉDIO \\
\hline 05000318 & 3,480 & 27 & 7,8 & 0,074 & $2,1 \%$ & MUITO BAIXO \\
\hline 05000319 & 2,288 & 47 & 20,5 & 0,048 & $2,1 \%$ & MUITO BAIXO \\
\hline 05000320 & 1,195 & 13 & 10,9 & 0,077 & $6,4 \%$ & MUITO BAIXO \\
\hline 05000321 & 0,870 & 10 & 11,5 & 0,341 & $39,2 \%$ & MUITO BAIXO \\
\hline 05000322 & 1,138 & 55 & 48,3 & 0,140 & $12,3 \%$ & MUITO BAIXO \\
\hline
\end{tabular}

a Fonte: IBGE (2011a).

Através da análise da Figura 33 e dos dados apresentados na Tabela 11, observa-se que a área inundada intercepta 54 distritos, sendo que quase metade deles apresenta risco baixo (10) ou muito baixo (15). Para estes setores, não devem ser descartadas medidas de intervenção, que devem estar voltadas principalmente à contenção da expansão urbana. Áreas recreativas são uma boa alternativa para limitar a ocupação e promover a valorização do entorno.

As áreas inundadas pelo rio Atibaia para os critérios selecionados somam 12,9 mil $\mathrm{km}^{2}$, sendo que $41 \%$ destas áreas apresentam médio risco e correspondem a regiões que devem sofrer intervenções de modo a conter a expansão demográfica e corrigir a ocupação, de modo a reduzir o risco.

Do total de áreas inundadas, $11 \%$ encontram-se em setores classificados com risco muito alto, compreendendo 7 setores. Estas áreas devem ser consideradas prioritárias no caso de medidas de intervenção, visando à diminuição do risco. Em seguida, devem ser tomadas medidas de proteção às áreas de alto risco, que abrangem 7 setores e somam quase 3,0 mil km² de áreas inundadas.

A distinção entre os critérios que regem a análise do risco - áreas inundadas e densidade populacional - se faz necessária para a compreensão do que também foi observado por Vendruscolo (2007), que afirma que, ainda que as inundações sejam inevitáveis, o risco pode ser manejado mediante a gestão adequada das condições 
da vulnerabilidade local. A Figura 34 apresenta o cruzamento das áreas identificadas com risco alto e muito alto às imagens de satélite disponíveis.

Por meio deste cruzamento, é possível observar algumas aglomerações urbanas localizadas nas áreas de maior risco. Esta aderência revela a coerência da metodologia adotada para a identificação dos riscos, à medida que estes núcleos urbanos localizados em zonas inundáveis devem sofrer intervenções prioritariamente de modo a garantir a segurança da população local.

De modo a incluir o gerenciamento do risco às inundações no zoneamento urbano, as finalidades, permissões e restrições para cada zona definida no CURMA devem contemplar as limitações sugeridas para as faixas inundáveis com restrição à ocupação e também as ações necessárias e prioritárias para a redução do risco. Cada zona poderia ser dividida em subáreas com base nos limites das inundações definidas para o período de retorno de 100 anos e, então, regulamentações especiais seriam criadas para estas áreas inundáveis, com base, se possível, nas finalidades originais de cada zona. Os riscos estimados para os setores censitários devem servir para priorizar as áreas que receberão medidas de intervenção.

Não é necessário, no entanto, que as definições da ocupação para as áreas inundáveis sejam previstas por ambas as ferramentas que regulamentam a APA ou o Plano Diretor, no caso, o Plano de Manejo e o CURMA, respectivamente. Seria suficiente que um destes instrumentos previsse as restrições da ocupação com base no risco das inundações e que estas fossem acatadas nas definições do outro instrumento. Neste sentido, o Código de Urbanismo e Meio Ambiente já prevê, no artigo 50ำ, que restrições específicas associadas a áreas de conservação enquadradas como Unidades de Proteção Integral ou de Uso Sustentável previstas pelo SNUC, Áreas de Preservação Permanente nos termos do Código Florestal ou áreas tombadas - devem prevalecer. Assim, a regulamentação das restrições às áreas inundáveis poderia ser dada através do Plano de Manejo da APA Várzeas do Atibaia, a ser instituído, e pelas definições já contidas na lei que rege o novo Código Florestal. Por outro lado, conforme já mencionado, a análise da legislação apresentada vincula a definição da regulamentação do uso do solo especificamente ao plano diretor e, no caso específico do mapeamento de áreas inundáveis, a legislação federal já dá indícios da tendência da obrigatoriedade de inclusão deste mapeamento também no plano diretor. 


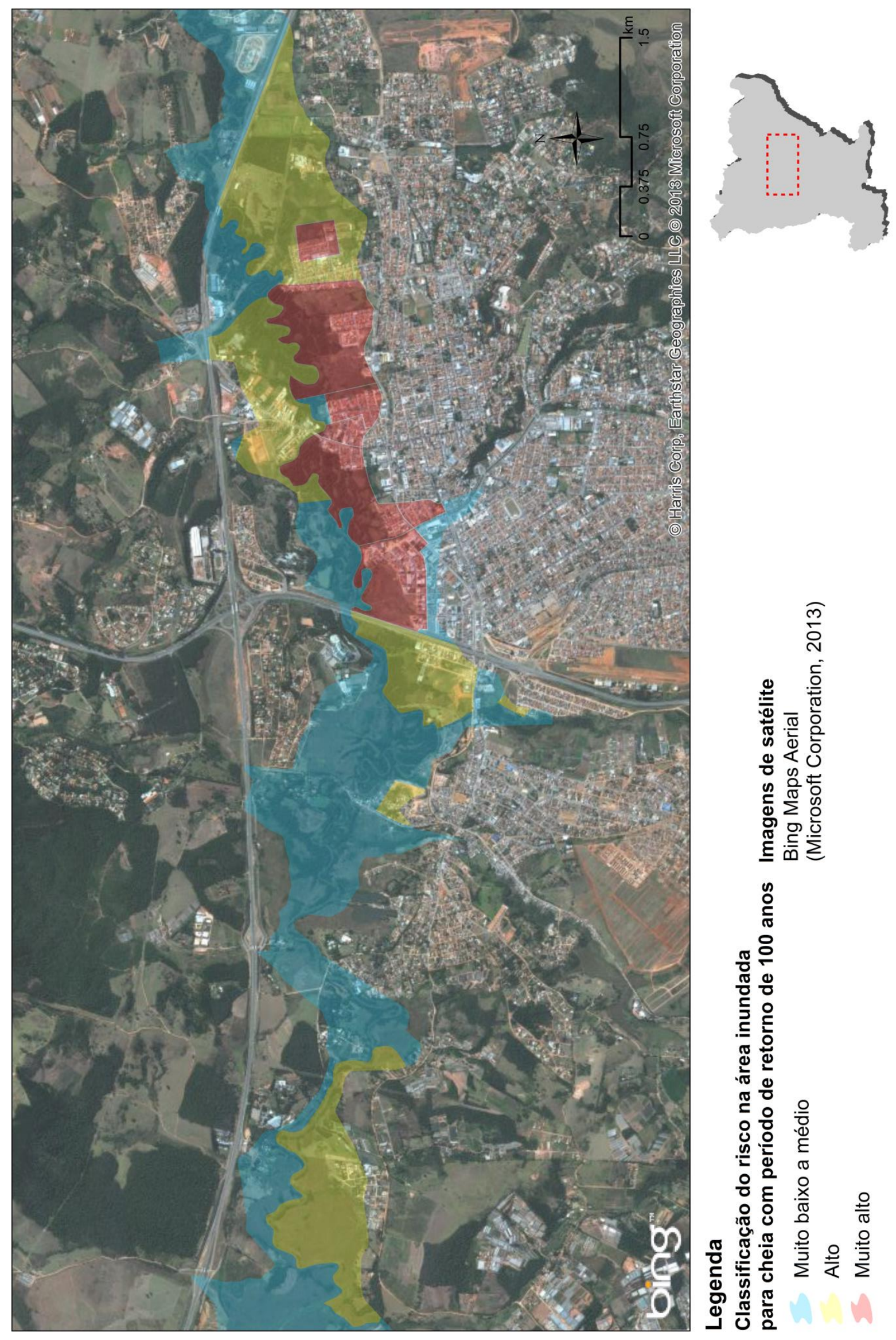

Figura 34 - Identificação das áreas de risco alto e muito alto. 


\subsubsection{Proposição de medidas de intervenção}

As principais medidas de intervenção que visam à diminuição do risco consistem na remoção da população para reduzir o grau de adensamento nas áreas inundadas, minimizando os prejuízos das enchentes e facilitando a ação em situações de emergência. Em áreas ainda pouco desenvolvidas, a contenção da ocupação se apresenta como uma importante medida de controle.

Ainda que nenhuma população seja, em princípio, irremovível, medidas de remoção e realocação são comumente malvistas pela comunidade e o poder público. Em situações como estas, algumas alternativas podem ser implementadas, como sistemas de alerta e previsão de enchentes. Estas medidas não reduzem a vulnerabilidade da população ao risco das inundações, mas podem, no entanto, ser bastante úteis na execução de planos de emergência. Medidas estruturais, por outro lado, são exemplos de intervenções que podem ser adotadas em áreas já consolidadas para reduzir a vulnerabilidade da comunidade às cheias. Nestes casos, o estudo realizado por DAEE (2011b) sugere um investimento de mais de 93 milhões de reais para a construção de diques para a proteção das áreas inundáveis altamente adensadas no município de Atibaia. Ainda em locais onde a realocação de habitações é considerada inviável, seguros contra enchentes, que permitem o ressarcimento contra os prejuízos causados pelas enchentes, podem ser uma medida bastante útil, desde que sejam adotados padrões construtivos compatíveis com as áreas inundáveis. Para as áreas em processo de desenvolvimento, construções à prova de enchentes também devem fundamentar os critérios de aprovação de projetos destas obras. Em áreas mais críticas, no entanto, estas medidas dificilmente substituem a necessidade de remoção da população, conceito que deve ser cuidadosamente avaliado.

A elaboração do Plano de Contingência de Proteção e Defesa Civil, de competência municipal, deve estar articulada com o zoneamento das áreas inundáveis e pode ser complementada por sistemas de alerta e previsão de enchentes. Já as restrições quanto ao uso e ocupação do solo nestas áreas, conforme mencionado, devem ser instituídas através das regulamentações do Plano Diretor, em complemento às definições contidas na lei que rege o novo Código Florestal. As regras estabelecidas devem ser bastante claras e objetivas, pois 
diretrizes muito vagas dão margem à sua não aplicação por parte dos administradores (SÃO PAULO, 2012).

O ordenamento territorial proposto no Plano Diretor deve complementar ou substituir o zoneamento vigente estabelecido pelo CURMA. A demarcação da zona com restrições deve ser dada a partir da delimitação das manchas de inundação para o período de retorno de 100 anos, levando em conta ainda a identificação dos riscos com base na vulnerabilidade de cada região para priorizar as ações necessárias para a correção do espaço. A subdivisão da zona com restrições pode manter o zoneamento definido no CURMA para as categorias residenciais, mistas, exclusivamente econômicas e especiais, sendo que as definições para cada categoria devem ser adaptadas às ressalvas gerais da zona com restrições definida através do mapeamento das áreas de inundação. O zoneamento deve incluir também os limites da zona de passagem de enchentes, que constitui uma área estratégica para a constituição de parque linear. Este limite pode ser incrementado pela definição das APPs, de modo a reforçar as restrições impostas pela legislação federal. Neste caso, as definições propostas pelo Código de Urbanismo e Meio Ambiente podem ser descartadas, uma vez que as regras para a zona de passagem de enchentes devem ser homogêneas. Para as demais áreas, denominadas zonas de baixo risco, não são necessárias restrições relativas ao controle de enchentes e podem ser mantidas as definições iniciais propostas pelo CURMA.

O zoneamento proposto está apresentado na Figura 35. Na sequência, na Tabela 12, são apresentadas sugestões que podem ser incluídas na regulamentação do Plano Diretor. As restrições de uso e ocupação do solo sugeridas referem-se apenas à manutenção dos impactos causados pelas inundações e devem ser complementadas através de regras relativas aos demais aspectos do Código. Além disso, as demais políticas de uso do solo, incluindo o Plano de Manejo da APA Várzeas do Atibaia e políticas municipais de habitação e saneamento, devem ser adaptadas no sentido de se manter coerência com o zoneamento definido.

Observa-se que, como regra geral, as instalações críticas, como postos de saúde, escolas, estações de polícia e bombeiro, postos de gasolina e depósitos de materiais perigosos devem ser suprimidas em todas as categorias de zonas com restrições relativas às inundações. A manutenção das demais construções existentes é permitida desde que estas se adaptem aos critérios de construção à 
prova de enchentes, apresentados na Tabela 13, que também devem vigorar para novas construções.

As exigências impostas pelo zoneamento devem prever, ainda, um período de adaptação às atividades e instalações que devem ser suprimidas ou sofrer alterações para atender às conformidades das diretrizes previstas para cada tipo de zona. Os prazos podem ser estipulados em função do risco atribuído para cada setor censitário (vide Figura 33), sendo que os setores de risco alto e muito alto devem concentrar grande parte das medidas a serem aplicadas no curto e médio prazo.

A revisão do Plano Diretor e a consequente reclassificação das zonas devem abordar novos critérios de análise, pois, à medida que são incorporados padrões construtivos à prova de enchente, a definição do risco de cada setor passa a ter um novo conceito, uma vez que não é mais possível estimar a vulnerabilidade do setor em função apenas da densidade populacional. 


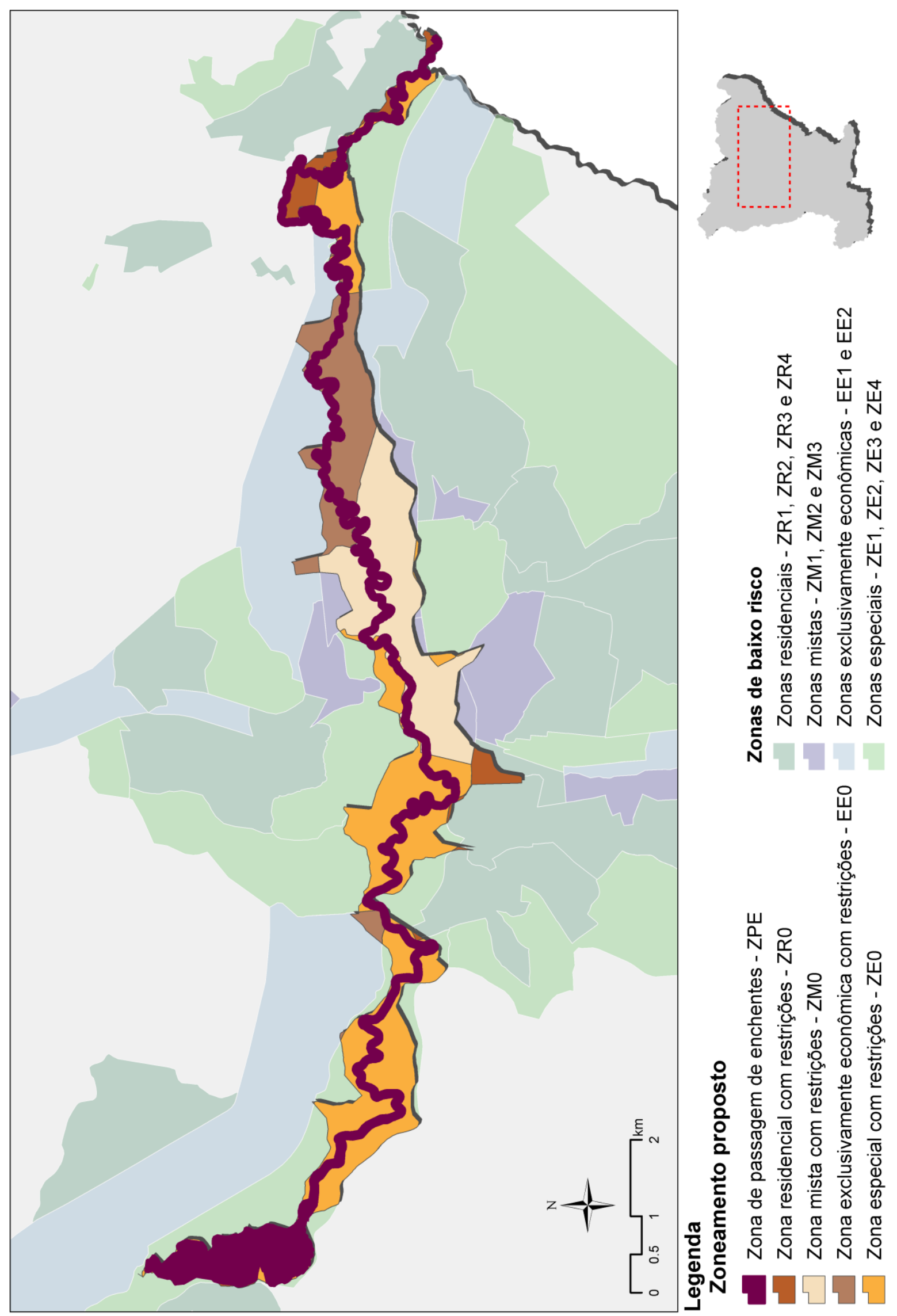

Figura 35 - Zoneamento de uso e ocupação do solo proposto para as áreas inundáveis no município de Atibaia ao longo do rio Atibaia. 
Tabela 12 - Sugestão de elementos para regulamentação do zoneamento de uso e ocupação do solo proposto para as áreas inundáveis no município de Atibaia ao longo do rio Atibaia.

\section{ZONA DE PASSAGEM DE ENCHENTE (ZPE)}

- Área de uso exclusivo para a manutenção das condições hidrológicas da várzea do rio Atibaia, sendo permitidas instalações voltadas ao lazer que não comprometam tais condições;

\begin{tabular}{|c|c|}
\hline 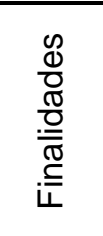 & $\begin{array}{l}\text { - Reduzir o grau de adensamento populacional, minimizando os prejuízos das enchentes e } \\
\text { facilitando a ação em situações de emergência; } \\
\text { - Assegurar condições hidrológicas para a passagem das enchentes; } \\
\text { - Ocupar a área com instalação de parque linear ou estruturas similares, para evitar a } \\
\text { ocupação inadequada e garantir a utilidade da área em períodos secos; }\end{array}$ \\
\hline 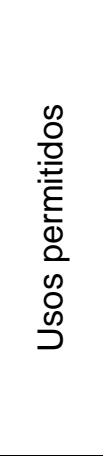 & $\begin{array}{l}\text { - Usos agrícolas, parques, áreas verdes, pistas de corrida, quadras e outros equipamentos de } \\
\text { recreação e lazer semelhantes, sendo incentivada a criação de parques lineares e a } \\
\text { recuperação da vegetação ripária ou ciliar para restabelecimento de suas funções hidrológicas } \\
\text { e ecológicas; } \\
\text { - Calçadas; } \\
\text { - Linhas de serviço de utilidade pública, como linhas de transmissão e condutos hidráulicos, } \\
\text { quando comprovada necessidade prática; } \\
\text { - Atividades de manutenção pública de ruas, pontes, outros meios de transporte similares e } \\
\text { lou de utilidade pública e instalações de drenagem de águas pluviais e restauração de áreas } \\
\text { ribeirinhas; }\end{array}$ \\
\hline 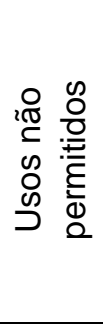 & $\begin{array}{l}\text { - Cercas ou muros extensos; } \\
\text { - Novos empreendimentos, reconstruções ou ampliações de qualquer tipo; } \\
\text { - Uso de fertilizantes e pesticidas; } \\
\text { - Todas as construções existentes, incluindo as de caráter residencial, não-residencial e } \\
\text { instalações críticas, como postos de saúde, escolas, estações de polícia e bombeiro, postos } \\
\text { de gasolina e depósitos de materiais perigosos, ou que não atendam aos usos permitidos } \\
\text { para esta área, devem ser suprimidas; }\end{array}$ \\
\hline & ZONA RESIDENCIAL COM RESTRIÇÕES (ZR0) \\
\hline 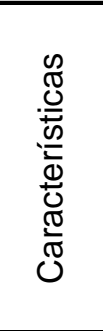 & $\begin{array}{l}\text { - Áreas de uso residencial diversificado, já comportando a atividade residencial multifamiliar, } \\
\text { com os tipos de empreendimentos correspondentes; } \\
\text { - Baixa densidade populacional; } \\
\text { - Alguma diversificação na tipologia dos empreendimentos; } \\
\text { - Admitida proporção média de usos não-residenciais predominantemente ligados às } \\
\text { necessidades diárias da população, com alguma abertura para os mais diversificados, de } \\
\text { baixo grau de incômodo; }\end{array}$ \\
\hline 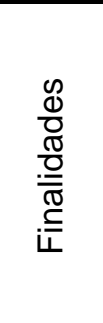 & $\begin{array}{l}\text { - Reduzir o grau de adensamento populacional, minimizando os prejuízos das enchentes e } \\
\text { facilitando a ação em situações de emergência; } \\
\text { - Acolher, no ordenamento urbanístico, atividades não-residenciais existentes, sem ocorrência } \\
\text { de conflitos de vizinhança, e sem impactos negativos ao assentamento e ao meio ambiente; } \\
\text { - Favorecer a oferta de comércio e serviços de interesse direto dos moradores da zona; } \\
\text { - Incentivar a instalação de equipamentos de recreação e lazer, de modo a preencher espaços } \\
\text { desocupados e conter o adensamento populacional; }\end{array}$ \\
\hline
\end{tabular}


Tabela 12 - Sugestão de elementos para regulamentação do zoneamento de uso e ocupação do solo proposto para as áreas inundáveis no município de Atibaia ao longo do rio Atibaia (continuação)

\section{ZONA RESIDENCIAL COM RESTRIÇÕES (ZR0) (continuação)}

- Usos agrícolas, pastagens, viveiros de plantas, jardins, parques, áreas verdes, pistas de corrida, quadras e outros equipamentos de recreação e lazer semelhantes;

- Ruas, pontes e outros meios de transporte similares, lagos, lagoas, e infraestruturas

? associadas, tais como barragens, reservatórios de detenção ou retenção, vertedouros, etc., quando comprovada necessidade prática;

Фे - Construções residenciais e não-residenciais existentes, exceto instalações críticas, desde

\% que atendem a critérios de construções à prova de enchentes definidos;

ڤ - Novas construções e ampliações, para usos residenciais e não-residenciais, desde que atendam aos critérios de construções à prova de enchentes definidos;

- Porões e pavimentos subterrâneos, apenas no caso de instalações não-residenciais, desde que atendam a critérios de construções à prova de enchentes definidos;

- Cercas ou muros extensos;

of - Depósito e armazenamento de equipamentos e materiais flutuantes;

$\stackrel{2 \pi}{\complement}$ 은 - Uso de fertilizantes e pesticidas;

Oू - Porões e pavimentos subterrâneos, no caso de instalações residenciais;

$\stackrel{0}{\varrho}$ - Instalações críticas, como postos de saúde, escolas, estações de polícia e bombeiro, postos de gasolina e depósitos de materiais perigosos;

\section{ZONA MISTA COM RESTRIÇÕES (ZM0)}

\begin{tabular}{|c|c|}
\hline 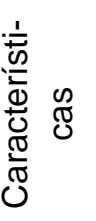 & $\begin{array}{l}\text { - Áreas de predominância de usos não-residenciais, podendo conviver com usos residenciais, } \\
\text { sem maiores estímulos ao aumento destes; } \\
\text { - Densidade populacional baixa; } \\
\text { - Diversificação dos usos não-residenciais avançada, podendo comportar alguns de } \\
\text { características não-poluidoras, porem, com grau médio de incômodo; }\end{array}$ \\
\hline
\end{tabular}

- Reduzir o grau de adensamento populacional, minimizando os prejuízos das enchentes e

\& facilitando a ação em situações de emergência;

- Acolher no ordenamento urbanístico concentrações de usos econômicos existentes que não apresentem impactos urbanísticos e ambientais negativos;

i= - Incentivar a instalação de equipamentos de recreação e lazer, de modo a preencher espaços desocupados e conter o adensamento populacional;

- Usos agrícolas, pastagens, viveiros de plantas, jardins, parques, áreas verdes, pistas de corrida, quadras e outros equipamentos de recreação e lazer semelhantes;

- Ruas, pontes e outros meios de transporte similares, lagos, lagoas, e infraestruturas

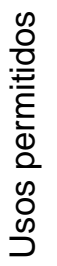
associadas, tais como barragens, reservatórios de detenção ou retenção, vertedouros, etc., quando comprovada necessidade prática;

- Construções residenciais e não-residenciais existentes, exceto instalações críticas, desde que atendem a critérios de construções à prova de enchentes definidos;

- Novas construções e ampliações, apenas para usos não-residenciais, desde que atendam aos critérios de construções à prova de enchentes definidos;

- Porões e pavimentos subterrâneos, apenas no caso de instalações não-residenciais, desde que atendam a critérios de construções à prova de enchentes definidos;

- Cercas ou muros extensos;

\& $\stackrel{0}{\circ}$ - Depósito e armazenamento de equipamentos e materiais flutuantes;

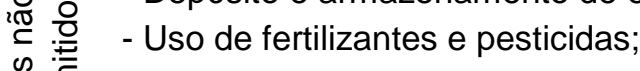

号 - Porões e pavimentos subterrâneos, no caso de instalações residenciais;

$\stackrel{\mathscr{D}}{\supset}$ - Instalações críticas, como postos de saúde, escolas, estações de polícia e bombeiro, postos de gasolina e depósitos de materiais perigosos; 
Tabela 12 - Sugestão de elementos para regulamentação do zoneamento de uso e ocupação do solo proposto para as áreas inundáveis no município de Atibaia ao longo do rio Atibaia (continuação)

\section{ZONA EXCLUSIVAMENTE ECONÔMICA COM RESTRIÇÕES (EE0)}

- Áreas para usos não-residenciais, admitidos estes, apenas, quando existentes, sobre áreas urbanizadas regularmente aprovadas.

I] - Áreas de localização apropriada para estabelecimentos industriais, comerciais, e no que

$\stackrel{0}{0}$ couber, de serviços, de grande porte, e de alto grau de incômodo, embora não- poluidores do

क्ष meio ambiente.

đ్ - Áreas que reúnem condições para concentrações funcionais de estabelecimentos industriais,

ठ̄ comerciais, e de serviços, de grande porte.

- Densidade nula ou muito baixa, resultante, apenas, do assentamento residencial existente, em parcelamentos regularmente aprovados.

\begin{tabular}{|c|c|}
\hline 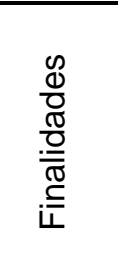 & $\begin{array}{l}\text { - Reduzir o grau de adensamento populacional, minimizando os prejuízos das enchentes e } \\
\text { facilitando a ação em situações de emergência; } \\
\text { - Potencializar o aproveitamento do "corredor de exportação" da Rod. D. Pedro I, habilitando a } \\
\text { faixa ao longo do mesmo para a concentração de usos não residenciais, sem riscos de } \\
\text { conflitos de vizinhança com usos incompatíveis, privilegiando atividades dinâmicas, de alto } \\
\text { poder multiplicador, de alto valor agregado, não poluidoras, e intensivas em uso de tecnologia; }\end{array}$ \\
\hline 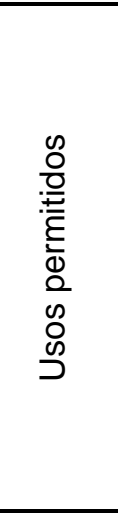 & $\begin{array}{l}\text { - Usos agrícolas, pastagens, viveiros de plantas, jardins, parques, áreas verdes, pistas de } \\
\text { corrida, quadras e outros equipamentos de recreação e lazer semelhantes; } \\
\text { - Ruas, pontes e outros meios de transporte similares, lagos, lagoas, e infraestruturas } \\
\text { associadas, tais como barragens, reservatórios de detenção ou retenção, vertedouros, etc., } \\
\text { quando comprovada necessidade prática; } \\
\text { - Construções residenciais e não-residenciais existentes, exceto instalações críticas, desde } \\
\text { que atendem a critérios de construções à prova de enchentes definidos; } \\
\text { - Novas construções e ampliações, apenas para usos não-residenciais, desde que atendam } \\
\text { aos critérios de construções à prova de enchentes definidos; } \\
\text { - Porões e pavimentos subterrâneos, apenas no caso de instalações não-residenciais, desde } \\
\text { que atendam a critérios de construções à prova de enchentes definidos; }\end{array}$ \\
\hline \multirow[t]{2}{*}{ 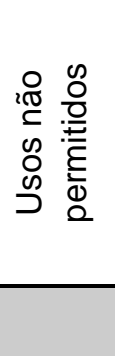 } & $\begin{array}{l}\text { - Cercas ou muros extensos; } \\
\text { - Depósito e armazenamento de equipamentos e materiais flutuantes; } \\
\text { - Uso de fertilizantes e pesticidas; } \\
\text { - Porões e pavimentos subterrâneos, no caso de instalações residenciais; } \\
\text { - Instalações críticas, como postos de saúde, escolas, estações de polícia e bombeiro, postos } \\
\text { de gasolina e depósitos de materiais perigosos; }\end{array}$ \\
\hline & ZONA ESPECIAL COM RESTRIÇÕES (ZE0) \\
\hline 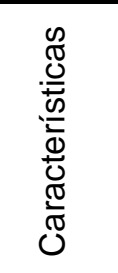 & $\begin{array}{l}\text { - Áreas objeto de severas restrições de uso e ocupação corrente, abertas, porém, a iniciativas } \\
\text { de mercado que impliquem em maior aproveitamento, desde que cada novo empreendimento } \\
\text { reúna condições de absorver, no interior de sua delimitação, a totalidade dos impactos } \\
\text { urbanísticos e ambientais que provoque. } \\
\text { - Áreas nas quais o uso para fins turísticos e recreativos deverá ser privilegiado, demandando- } \\
\text { se que os usos para outros fins reúnam condições de compatibilidade com aqueles. }\end{array}$ \\
\hline
\end{tabular}


Tabela 12 - Sugestão de elementos para regulamentação do zoneamento de uso e ocupação do solo proposto para as áreas inundáveis no município de Atibaia ao longo do rio Atibaia (conclusão)

\section{ZONA ESPECIAL COM RESTRIÇÕES (ZE0) (continuação)}

- Reduzir o grau de adensamento populacional, minimizando os prejuízos das enchentes e facilitando a ação em situações de emergência;

- Preservar as atividades rurais ainda existentes na borda interior da área urbana contínua;

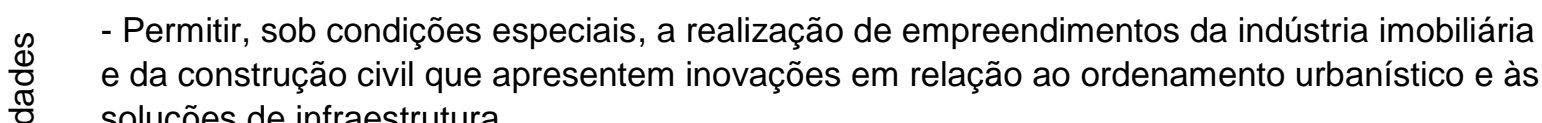
soluções de infraestrutura.

$\stackrel{\widetilde{T}}{=}$ - Abrir possibilidades de localização e exercício de atividades diversificadas na área

¿ preservada, sem alterações no perfil topográfico e visual do sítio original de implantação da cidade.

- Incentivar a instalação de equipamentos de recreação e lazer, de modo a preencher espaços desocupados e conter o adensamento populacional;

- Usos agrícolas, pastagens, viveiros de plantas, jardins, parques, áreas verdes, pistas de corrida, quadras e outros equipamentos de recreação e lazer semelhantes;

- Ruas, pontes e outros meios de transporte similares, lagos, lagoas, e infraestruturas

: associadas, tais como barragens, reservatórios de detenção ou retenção, vertedouros, etc., quando comprovada necessidade prática;

- Construções residenciais e não-residenciais existentes, exceto instalações críticas, desde

o que atendem a critérios de construções à prova de enchentes definidos;

O - Novas construções e ampliações, apenas para usos não-residenciais, desde que atendam aos critérios de construções à prova de enchentes definidos;

- Porões e pavimentos subterrâneos, apenas no caso de instalações não-residenciais, desde que atendam a critérios de construções à prova de enchentes definidos;

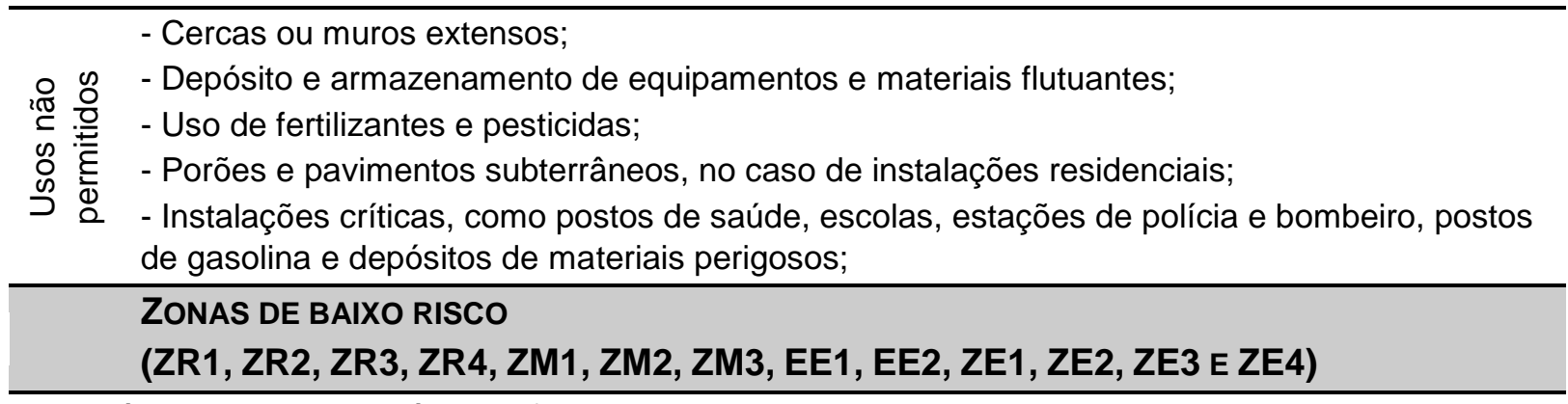

Não há restrições nestas áreas referentes ao risco de inundações e podem ser mantidas as definições iniciais propostas pelo CURMA. 
Tabela 13 - Critérios para construções à prova de enchentes, a serem incluídos na regulamentação do zoneamento proposto para as áreas inundáveis no município de Atibaia.

\section{CRITÉRIOS PARA CONSTRUÇõES À PROVA DE ENCHENTES}

- estabelecimento de, pelo menos, um piso com nível superior à linha d'água estimada;

- prever o transporte de material de valor para pisos superiores e a habitação por até três meses nos pisos superiores;

- vedação (temporária ou permanente) das aberturas como portas, janelas e dispositivos de ventilação;

- elevação de estruturas existentes;

- construção de novas estruturas sobre pilotis;

- construção de pequenos diques circundando as estruturas;

- realocação ou proteção individual de artigos que possam ser danificados;

- realocação de equipamentos elétricos para os pisos superiores e desligamento do sistema de alimentação durante o período de cheia;

- uso de material resistente à submersão ou contato com a água;

- estanqueidade e reforço das paredes de porões e pisos sujeitos a inundação;

- ancoragem de paredes contra deslizamentos;

- prever os efeitos das enchentes nos projetos de esgotos pluvial e cloacal;

- estruturalmente, as construções devem ser projetadas para resistir à pressão hidrostática, empuxos, momentos e erosão;

- para os pisos previstos que inundem, prever o escoamento através da obra, evitando o desmoronamento de paredes.

Observação: o não cumprimento a um ou mais critérios não desqualifica a classificação de construção à prova de enchente, mediante justificativa técnica. 


\section{CONCLUSÕES E RECOMENDAÇÕES}

A metodologia adotada se mostrou suficiente para atender aos objetivos do trabalho, que se propôs a sugerir restrições do uso do solo nas áreas inundáveis identificadas, devendo ser incorporada a políticas públicas de ordenamento territorial, e pode ser facilmente adaptada a demais áreas urbanas que sofrem com inundações ribeirinhas. A integração entre as etapas de mapeamento das áreas inundáveis aos limites físicos e políticos da área de estudo permite diversas possibilidades de análise, dada a riqueza das ferramentas utilizadas.

O processo de identificação das áreas inundáveis envolve extensas análises hidrológicas e hidráulicas e exige, ainda, bons conhecimentos em técnicas de geoprocessamento, uma vez que a análise e o tratamento dos dados de batimetria e terreno compõem os fatores mais críticos para a precisão dos resultados desta etapa. Além disso, as atividades antrópicas afetam necessariamente a paisagem e a dinâmica da bacia hidrográfica, o que motiva a constante atualização deste processo. Ainda que, em alguns casos, cartas topográficas representem o terreno de forma mais adequada, como foi constatado no caso de estudo deste trabalho, em outras situações, dados obtidos por sensoriamento remoto podem ser bastante úteis, consideradas suas limitações, à medida que são produzidos em larga escala e estão comumente disponíveis de forma gratuita.

A simulação computacional desenvolvida no modelo PCSWMM explorou apenas parte dos recursos disponíveis no programa e permitiu elevado grau de satisfação da calibração dos dados simulados em relação àqueles observados em campo. A versão do aplicativo utilizada, no entanto, ainda que disponha de avançadas ferramentas de geoprocessamento, não permite a visualização em planta dos níveis das lâminas d'água estimadas, o que limita as análises decorrentes dos resultados desta etapa. Apesar disso, o mapeamento de áreas de inundação se confirmou como importante instrumento para o planejamento do uso do solo e hierarquização de áreas a receberem medidas de controle mais imediatas para assegurar a ocupação segura das áreas de várzea.

O levantamento da legislação vigente permitiu analisar a complexidade envolvida no processo de gestão dos municípios brasileiros, que deve observar as 
competências das esferas federal e estaduais, além de diretrizes de bacias hidrográficas. Desde o final da década de 1970, já era previsto em lei federal que os municípios regulamentassem as áreas sujeitas à inundação e, desde então, um volumoso conjunto de leis retoma o assunto, sem que haja, no entanto, um avanço expressivo nas legislações municipais acerca do mesmo. O excesso de documentos encontrados que abordam a questão do planejamento territorial e do mapeamento de áreas inundáveis, a redundância de temas e a falta de continuidade de algumas medidas legislativas que exigem regulamentação abrem espaço para uma ocupação mais desordenada e confusa e sugerem a necessidade de uma legislação mais moderna e eficiente.

O estudo de caso do município de Atibaia permitiu levantar questionamentos a respeito dos instrumentos existentes para o estabelecimento do zoneamento urbanístico e ambiental, uma vez que a legislação municipal prevê a elaboração de documentos técnicos nos quais se estabeleça o zoneamento de áreas de proteção ambiental, além do zoneamento existente no código que regulamenta o plano diretor, sendo este último o instrumento oficial previsto na lei federal para o ordenamento urbanístico. Há ainda rígidas restrições previstas para as áreas de preservação permanente, no âmbito do Código Florestal, que regulamenta as margens de rios e córregos. Se, por um lado, o Plano Diretor, o Sistema Nacional de Unidades de Conservação e o Código Florestal têm, por definição, objetivos diferentes; por outro, seria conveniente uma consolidação de suas diretrizes, o que facilitaria a vida do cidadão comum em busca de informação a respeito de determinada área de interesse. Além da integração das próprias políticas públicas de planejamento da ocupação do solo, estas, em teoria, também deveriam estar articuladas a políticas de recursos hídricos, defesa civil, transporte e saneamento básico - um desafio para um sistema tão complexo.

O município de Atibaia apresenta uma situação crítica de ocupação de várzeas e tem sofrido os impactos de recorrentes catástrofes ocasionadas recentemente, mesmo com vazões de baixa magnitude. A legislação vigente dá indícios da intenção de promover o uso do solo com respeito ao meio ambiente, no entanto, o zoneamento em vigor ainda dá margem para a ocupação em áreas ribeirinhas deliberadamente.

A proposição de critérios de regulamentação do uso do solo é a etapa mais delicada deste trabalho, uma vez que se almeja sua adequação para o formato de 
lei. Ao introduzir restrições à ocupação, é fundamental ainda que a legislação dê alternativas e condições para garantir sua obediência, auxiliando na adaptação dos proprietários dos espaços - no caso de construções existentes que devem ser realocadas ou readequadas estruturalmente para suportar os impactos das cheias. Além disso, ocupações compatíveis com as inundações - como parques lineares, por exemplo - devem ser incentivadas, para prevenir seu uso irregular e diminuir a especulação imobiliária inerente a qualquer restrição de uso do solo.

O desafio deste processo é estimular sua continuidade, o que exige, além de fortalecimento institucional, a conexão entre as demais medidas estruturais e não estruturais. As regulamentações de uso do solo não podem ser vistas como medidas isoladas de convivência com as cheias. Mesmo que haja uma realocação de todos os equipamentos básicos de serviços públicos, ainda restarão residências e atividades econômicas em áreas sujeitas à inundação e, ainda que atendam aos padrões construtivos exigidos, sua localização leva à necessidade de um plano de ação junto à Defesa Civil. O município também deve estar preparado para as situações que superem sua capacidade de planejamento, sendo que sistemas de alerta, previsão e seguro contra enchentes surgem como medidas complementares bastante interessantes. $O$ tomador de decisão deve ter em mente a importância de tais medidas não estruturais, visto que são medidas de caráter institucional e têm pouca visibilidade política, e deve aliá-las a medidas estruturais, como diques e reservatórios, por exemplo, de forma a complementar a segurança da população.

A metodologia apresentada por ser aplicada a outras áreas urbanas com inundações ribeirinhas sem grandes dificuldades. $O$ estudo de regiões que sofrem com inundações ocasionadas devido à urbanização demanda uma sofisticação adicional à etapa de mapeamento das áreas inundáveis, à medida que são sistemas mais complexos, o que exigira informações mais detalhadas.

O trabalho apresentou uma proposta baseada no extravasamento das águas do rio Atibaia, o que representa uma análise da principal área inundada do município de Atibaia. Outras áreas adjacentes a importantes afluentes, no entanto, devem ser analisadas para compor os critérios de uso e ocupação do solo no município, ainda que sejam realizadas análises mais empíricas.

A metodologia desenvolvida busca constituir um sistema de suporte à decisão com margem a diferentes interpretações e consiste em uma sugestão para a revisão dos critérios de zoneamentos em vigor. A definição dos critérios de ocupação 
sugeridos neste trabalho com base na metodologia de mapeamento apresentada deve compor diretrizes para a formulação de políticas públicas locais, permitindo um melhor convívio da sociedade com as inundações, reduzindo a vulnerabilidade da comunidade local, minimizando as perdas econômicas e os impactos à saúde pública e garantindo maior segurança à população que vive nas proximidades dos corpos d'água. 


\section{REFERÊNCIAS}

ALVES SOBRINHO, T. et al. Delimitação automática de bacias hidrográficas

utilizando dados SRTM. Eng. Agríc., Jaboticabal, v.30, n.1, p.46-57, jan./fev. 2010.

ARCGIS Desktop. Version 10.0. Redlands, CA: Environmental Systems Research Institute, 2010.

ATIBAIA. Lei Complementar no 507, de 5 de outubro de 2006. Dispõe sobre o Plano Diretor da Estância de Atibaia, para o período 2007/2016, e dá outras providências. Atibaia, SP: Prefeitura Municipal, Secretaria de Urbanismo e Meio Ambiente, 2006.

ATIBAIA. Prefeitura da Estância de Atibaia. Disponível em <http://www.atibaia.sp.gov.br>. Acesso em: 05 mai. 2011.

BARROS, M.T.L. (Org.). Gerenciamento Integrado de Bacias Hidrográficas em Áreas Urbanas - Sistema de Suporte ao Gerenciamento da Água Urbana - Estudo de Caso: Rio Cabuçu de Baixo, Cidade de São Paulo. São Paulo: Escola Politécnica da USP; CNQp, 2004.

. (Org.). Plano de Bacia Urbana: Relatório Final. São Paulo: CT-HIDRO, FINEP, CNPq, FUSP, EPUSP, 2005.

BELO HORIZONTE. Prefeitura Municipal; Secretaria Municipal de Políticas Urbanas (SMURBE); Superintendência de Desenvolvimento da Capital (SUDECAP). Carta de Inundações de Belo Horizonte: Identificação de áreas potencialmente suscetíveis. Belo Horizonte: jan.2009. Disponível em: <www.pbh.gov.br/>. Acesso em: 07 jul. 2011.

BRAGA, R. Política urbana e gestão ambiental: considerações sobre o plano diretor e o zoneamento urbano. In: CARVALHO, Pompeu F. de; BRAGA, Roberto (Org.).

Perspectivas de Gestão Ambiental em Cidades Médias. Rio Claro: LPM-UNESP, 2001. p. 95-109.

Planejamento urbano e recursos hídricos. In: BRAGA, R.; CARVALHO, P. F. C. Recursos hídricos e planejamento urbano e regional. Rio Claro: LPMIGCE-UNESP, 2003. p. 113-127. 
BRASIL. Ministério do Meio Ambiente. Agenda 21 brasileira: resultado da consulta nacional / Comissão de Políticas de Desenvolvimento Sustentável e da Agenda 21 Nacional. 2. ed. Brasília: Ministério do Meio Ambiente, 2004. 158 p.

Secretaria Nacional de Saneamento Ambiental. Gestão de águas pluviais urbanas / TUCCI, C.E.M. Brasília: Ministério das Cidades, 2006. 194p. (Saneamento para Todos; 4ํvolume).

. Ministério das Cidades; Instituto de Pesquisas Tecnológicas - IPT.

Mapeamento de Riscos em Encostas e Margem de Rios / CARVALHO, C.S.; MACEDO, E.S.de; OGURA, A.T. (Org.). Brasília: Ministério das Cidades; Instituto de Pesquisas Tecnológicas - IPT, 2007.

BRITO, Francisco Saturnino Rodrigues de. Melhoramentos do Rio Tietê em São Paulo. São Paulo: F. Briguiet, Secção de Obras d'O Estado de São Paulo, 1926. $270 \mathrm{p}$.

COBRAPE. Belo Horizonte usa Carta de Inundações para combater enchentes. COBRAPE - Companhia Brasileira de Projetos e Empreendimentos, Assessoria de Comunicação, 20 jan. 2010. Disponível em:

<http://www.cobrape.com.br/det_noticia.php?id=83>. Acesso em: 09 jul. 2011.

CRUZ, M.A.S.; SOUZA, C.F.; TUCCI, C.E.M. Controle da drenagem urbana no Brasil: avanços e mecanismos para sua sustentabilidade. In: XVII SIMPÓSIO BRASILEIRO DE RECURSOS HÍDRICOS, 2007, São Paulo. Anais..., São Paulo: ABRH, 2007.

DEPARTAMENTO DE ÁGUA E ENERGIA ELÉTRICA (DAEE). Unidade de Gerenciamento do Projeto Tietê - UGP-Tietê. Um Projeto para Acabar com as Inundações que São Paulo Enfrenta desde o Século XVII. Revista Engenharia, v. 59, n. 548, 2001.

Levantamento de pontos de inundação nos rios Jaguari e Atibaia em função das chuvas do período de dezembro de 2009 a fevereiro de 2010 a jusante dos Reservatórios do Sistema Cantareira. Piracicaba: DAEE, Diretoria da Bacia do Médio Tietê, Centro de Gerenciamento de Recursos Hídricos, 2010.

. Levantamento Topobatimétrico do trecho do Rio Atibaia inserido no Município de Atibaia, realizado pela Internave Engenharia, durante o período de 18/4/2011 a 13/5/2011. 2011a. 
Rios Atibaia e Jaguari: Estudos hidrológicos e hidráulicos, zoneamento de áreas inundáveis e medidas de combate à inundação. Escopo complementar para o rio Atibaia. [São Paulo]: Hidrostudio, 2011b.

DU, W. et al. Health Impacts of Floods. Prehospital and Disaster Medicine. v. 25, n. 3, p. 265-272, May/Jun. 2010.

EARTH REMOTE SENSING DATA ANALYSIS CENTER (ERSDAC). ASTER GDEM. v. 2. 2011. Disponível em <http://www.gdem.aster.ersdac.or.jp/>. Acesso em: 11 out. 2011.

EM-DAT. The OFDA/CRED International Disaster Database. Brussels: Centre for Research on the Epidemiology of Disasters; Université Catholique de Louvain, 2012. Disponível em: <http://www.emdat.be>. Acesso em: 05 jul. 2012.

EMPRESA PAULISTA DE PLANEJAMENTO METROPOLITANO (Emplasa). Rede urbana e regionalização do Estado de São Paulo. São Paulo: 2011.

ESTRELA. Lei n. 4.314 , de 10 de outubro de 2006. Cria o Plano Diretor de Desenvolvimento Integrado do Município e revoga o Plano Diretor - Lei Municipal 1.620, de 28 de dezembro de 1979. Estrela, RS: Prefeitura Municipal, 2006.

EUROPEAN EXCHANGE CIRCLE ON FLOOD MAPPING (EXCIMAP). Handbook on good practices for flood mapping in Europe. [S.I.]: European Comission, Waters Directors, Nov.2007.

FEDERAL EMERGENCY MANAGEMENT AGENCY (FEMA). Guidelines and Specifications for Flood Hazard Mapping Partners - Flood Studies and Mapping. v. 1. [S.I.]: Apr. 2003. Disponível em: <http://www.fema.gov/fhm/dl_cgs.shtm>. Acesso em: 03 jun. 2011.

Guidelines and specifications for flood hazard mapping partners. [S.I.]: Nov. 2009. Appendix C: Guidance for riverine flooding analysis and mapping. Disponível em: <http://www.fema.gov/fhm/dl_cgs.shtm>. Acesso em: 07 jun.2011.

Numerical Models Meeting the Minimum Requirements of the National Flood Insurance Program. [S.I]: 2010. Disponível em:

<http://www.fema.gov/plan/prevent/fhm/en_modl.shtm>. Acesso em: 05 jul.2011. 
FORT COLLINS. Fort Collins Utilities. Floodplain regulations for the Poudre River: Quick Guide. Fort Collins: 2010. Disponível em:

<http://www.fcgov.com/utilities/img/site_specific/uploads/quickguide-poudre.pdf>. Acesso em: 8 mai. 2010.

FUNDAÇÃO CENTRO TECNOLÓGICO DE HIDRÁULICA (FCTH). SAISP - Sistema de Alerta a Inundações de São Paulo. Disponível em: <http://www.saisp.br>. Acesso em: 20 mar. 2011.

. Previsão de Níveis e Vazões na Bacia do Rio Piracicaba - Relatório Parcial 01. [São Paulo]: 2012.

FUNDAÇÃO SEADE. Pesquisa Municipal Unificada - PMU. São Paulo. Disponível em: <http://www.seade.gov.br>. Acesso em: 5 Mai. 2011.

GARCIA, J. I. B. Monitoramento hidrológico e modelagem da drenagem urbana da bacia hidrográfica do Arroio Cancela. Dissertação (Mestrado) - Curso de PósGraduação em Engenharia Civil, Centro de Tecnologia, Universidade Federal de Santa Maria, 2005.

GOERL, R. F.; KOBIYAMA, M.; PELLERIN, J. R. G. M. Proposta metodológica para mapeamento de áreas de risco a inundação: estudo de caso do município de Rio Negrinho - SC. Bol. geogr., Maringá, v. 30, n. 1, p. 81-100, 2012.

INSTITUTO BRASILEIRO DE GEOGRAFIA E ESTATÍSTICA (IBGE). Atibaia. 1. ed. Rio de Janeiro: IBGE, Folha SF.23-Y-C-III-2. Escala 1: 50.000, 1984.

. Cidades@: Atibaia - SP. 2011a. Disponível em:

<http://www.ibge.gov.br/cidadesat>. Acesso em: 5 Mai. 2011.

. IBGE Censo 2010 - Sinopse do Censo demográfico 2010. IBGE, 2011b. Disponível em <http://www.censo2010.ibge.gov.br/sinopse>. Acesso em: 5 Mai. 2011.

KING, R. O. National Flood Insurance Program: Background, Challenges, and Financial Status. Congressional Research Service, R40650, 8 Apr. 2010.

KONIG, Rodrigo. Cobertura da Enchente. Atibaia.com.br, Atibaia, 11 Jan. 2011. Disponível em: <http://www.atibaia.com.br>. Acesso em: 8 Mai. 2011. 
LUCCI, R. M. et al. Avaliação altimétrica do modelo digital de elevação TOPODATA para utilização em estudos de linha d'água em canais naturais. In: XIX SIMPÓSIO BRASILEIRO DE RECURSOS HÍDRICOS, Maceió, AL, 2011. Anais... ABRH, 2011.

MARQUES, H. G. et al. Comparação entre os modelos de elevação SRTM, TOPODATA e ASTER na delimitação automática de rede de drenagem e limite de bacia hidrográfica. In: XV Simpósio Brasileiro de Sensoriamento Remoto - SBSR, Curitiba, PR, 2011. Anais... INPE: 2011.

MENDIONDO, E. M. (2005) Flood risk management of urban waters in humid tropics: early-warning, protection and rehabilitation. In: TUCCI, C.; GOLDENFUM, J. (Org.). Workshop on Integrated Urban Water Managmt. in Humid Tropics. Foz do Iguaçu: UNESCO, Apr. 2005.

MERWADE V.; COOK A.; COONROD J. GIS techniques for creating river terrain models for hydrodynamic modeling and flood inundation mapping. Environmental Modelling \& Software, v. 23/10-11, p. 1300-1311, 2008.

MERWADE, V. M. et al. Uncertainty in flood inundation mapping - current issues and future directions. ASCE Journal of Hydrologic Engineering, v. 13 ,n. 7, p. 608620, 2008.

MICROSOFT CORPORATION and its data suppliers. Bing Maps Aerial. 2013. Disponível em <http://www.bing.com/maps>. Acesso em: 21 Jan. 2013.

MIRANDA, E. E. de (Coord.). Brasil em Relevo. Campinas, SP: Embrapa Monitoramento por Satélite, 2005. Disponível em:

<http://www.relevobr.cnpm.embrapa.br>. Acesso em: 8 Mai. 2011.

MÜLLER, A. S. Aplicabilidade de medidas não estruturais no controle de cheias urbanas: estudo de caso Bacia Hidrográfica do Rio Cachoeira - Joinville - SP. Dissertação (Mestrado) - Escola Politécnica da Universidade de São Paulo. Departamento de Engenharia Hidráulica e Ambiental. São Paulo: 2011. 235 p.

NATIONAL RESEARCH COUNCIL (NRC). Mapping the zone: improving flood map accuracy. Washington: The National Academies Press, 2009. Disponível em: <http://www.nap.edu/catalog.php?record_id=12573>. Acesso em: 20 Jul. 2011.

PCSWMM 2012 Professional. Version 5.0.1249. Guelph, Ontario: CHI, 2012. 
PLÚVIO 2.1: Chuvas intensas para o Brasil. PRUSKI, F. F.; SILVA, D. D. GPRHDEA-UFV: 2006. Disponível em: < http://www.ufv.br/dea/gprh/softwares.htm>. Acesso em: 15 Abr. 2012.

POMPÊO, C. A. Drenagem Urbana Sustentável. Revista Brasileira de Recursos Hídricos, Associação Brasileira de Recursos Hídricos , v. 5, n. 1, p. 15-24, 2000.

RABINDRA, O.; SHIGENOBU, T.; TOSHIKAZU, T. Flood hazard mapping in developing countries: problems and prospects. Disaster Prevention and Management, v. 17, n. 1, p. 104-113, 2008.

ROSSMAN, L. A. Storm Water Management Model, Version 5.0: User's Manual. Cincinnati, Ohio: U.S. Enviromental Protect Agency, 2008.

SÃO PAULO (CIDADE). Secretaria Municipal de Desenvolvimento Urbano. Manual de drenagem e manejo de águas pluviais: gerenciamento do sistema de drenagem urbana. São Paulo: SMDU, 2012. 168p. il. v.1.

SANDERS, B. F. Evaluation of on-line DEMs for flood inundation modeling. Advances in Water Resources, v. 30, n. 8, p. 1831-1843, Aug. 2007.

SCHWAB, James C. (Ed.). Hazard Mitigation: Integrating Best Practices into Planning. Chicago: American Planning Association (APA), May 2010. Disponível em: <http://www.fema.gov/library/viewRecord.do?id=4267>. Acesso em: 7 Jul. 2011.

SHIDAWARA, M. Flood hazard map distribution. Urban Water, v. 1, p. 125-129, 1999.

SILVA, C.V.F. et al. Application of hydraulic, hydrologic and digital terrain modeling in flood risk area mapping. In: XIV WORLD WATER CONGRESS, PORTO DE GALINHAS, Recife, 2011. Anais..., 2011.

SILVA, R. T.; PORTO, M. F. do A. Gestão Urbana e Gestão das Águas: Caminhos da Integração. Estudos Avançados, São Paulo, v. 17, n. 47, Jan./Abr. 2003.

SISCAH - Sistema computacional para análises hidrológicas. Versão 1.0. SOUSA, H. T. de. et al. Brasília: ANA; Viçosa: UFV, 2009. 
TOMAZONI, J. C. et al. Uso de Modelo Digital de Elevação Gerados a partir do ASTER GDEM e SRTM para Caracterização de Rede de Drenagem. Revista Brasileira de Geografia Física. v. 2, p. 365-376, 2011.

TUCCI, C.E.M. Aspectos Institucionais do Controle das Inundações Urbanas. In: TUCCI, C.E.M. Aspectos Institucionais no Controle de Inundações. Brasília: Seminário de Recursos Hídricos do Centro-Oeste, 1999. Disponível em: <http://www.rhama.net/download/artigos/artigo9.pdf>. Acesso em: 8 Jul. 2011.

Águas no Meio Urbano. In: REBOUÇAS, A.C.; BRAGA Jr., B. P. F.; TUNDISI, J. G. (Ed.). Águas doces no Brasil: capital ecológico, uso e conservação. 3. ed. São Paulo: Escrituras Editora, 2006. p. 399-432.

. (Org.). Hidrologia: Ciência e Aplicação. 4. ed., 1. reimp. Porto Alegre: Editora da UFRGS; Coleção ABRH de Recursos Hídricos, 2009. 4 v.

TUCCI, C. E. M; BERTONI, J.C. (Org.). Inundações Urbanas na América do Sul. Porto Alegre: Associação Brasileira de Recursos Hídricos, 2003.

US ARMY CORPS OF ENGINEERS (USACE). Hydrologic Engineering Center. Disponível em: <http://www.hec.usace.army.mil>. Acesso em: 22 Mar. 2010.

VALERIANO, M. de M.. TOPODATA: Guia para utilização de dados geomorfológicos locais. São José dos Campos: INPE, 2008.

VENDRUSCOLO, S. Interfaces entre a Política Nacional de Recursos Hídricos e a Política Nacional de Defesa Civil, com relação aos Desastres Hidrológicos.

Dissertação (Mestrado) - Programa de Pós-graduação em Engenharia Ambiental da Universidade Federal de Santa Catarina. Florianópolis, SC: 2007

WHITE, Gilbert Fowler. Human Adjustments to Floods: A Geographical Approach to the Flood Problem in the United States. Chicago: University of Chicago, 1945. 225 p. 


\section{APÊNDICE A - PRINCIPAIS REFERÊNCIAS LEGISLATIVAS}

Este documento busca extrair da legislação vigente as principais menções ao tema de planejamento do uso e ocupação do solo em áreas com risco de inundação.

\section{Legislação federal}

\section{Lei no. 6.766, de 19 de dezembro de 1979}

Dispõe sobre o Parcelamento do Solo Urbano e dá outras Providências.

Artigo 1․ O parcelamento do solo para fins urbanos será regido por esta Lei.

Parágrafo único - Os Estados, o Distrito Federal e os Municípios poderão estabelecer normas complementares relativas ao parcelamento do solo municipal para adequar o previsto nesta Lei às peculiaridades regionais e locais.

Artigo 3‥ Somente será admitido o parcelamento do solo para fins urbanos em zonas urbanas, de expansão urbana ou de urbanização específica, assim definidas pelo plano diretor ou aprovadas por lei municipal. (Redação dada pela Lei no 9.785, de 1999)

Parágrafo único - Não será permitido o parcelamento do solo:

I - em terrenos alagadiços e sujeitos a inundações, antes de tomadas as providências para assegurar o escoamento das águas; (...)

Artigo 4‥ Os loteamentos deverão atender, pelo menos, aos seguintes requisitos:

I - as áreas destinadas a sistemas de circulação, a implantação de equipamento urbano e comunitário, bem como a espaços livres de uso público, serão proporcionais à densidade de ocupação prevista pelo plano diretor ou aprovada por lei municipal para a zona em que se situem. (Redação dada pela Lei no 9.785, de 1999) (...)

III - ao longo das águas correntes e dormentes e das faixas de domínio público das rodovias e ferrovias, será obrigatória a reserva de uma faixa não-edificável de 15 (quinze) metros de cada lado, salvo maiores exigências da legislação específica; (Redação dada pela Lei no 10.932, de 2004) 
IV - as vias de loteamento deverão articular-se com as vias adjacentes oficiais, existentes ou projetadas, e harmonizar-se com a topografia local.

$\S 1 \%$. A legislação municipal definirá, para cada zona em que se divida o território do Município, os usos permitidos e os índices urbanísticos de parcelamento e ocupação do solo, que incluirão, obrigatoriamente, as áreas mínimas e máximas de lotes e os coeficientes máximos de aproveitamento. (Redação dada pela Lei $n^{\circ}$ 9.785, de 1999) (...)

Artigo 7․ A Prefeitura Municipal, ou o Distrito Federal quando for o caso, indicará, nas plantas apresentadas junto com o requerimento, de acordo com as diretrizes de planejamento estadual e municipal: (...)

IV - as faixas sanitárias do terreno necessárias ao escoamento das águas pluviais e as faixas não edificáveis; (...)

\section{Lei no. 6.938, de 31 de agosto de 1981}

Dispõe sobre a Política Nacional do Meio Ambiente, seus fins e mecanismos de formulação e aplicação, e dá outras providências.

Artigo 2‥ A Política Nacional do Meio Ambiente tem por objetivo a preservação, melhoria e recuperação da qualidade ambiental propícia à vida, visando assegurar, no País, condições ao desenvolvimento socioeconômico, aos interesses da segurança nacional e à proteção da dignidade da vida humana, atendidos os seguintes princípios:

I - ação governamental na manutenção do equilíbrio ecológico, considerando o meio ambiente como um patrimônio público a ser necessariamente assegurado e protegido, tendo em vista o uso coletivo;

II - racionalização do uso do solo, do subsolo, da água e do ar;

III - planejamento e fiscalização do uso dos recursos ambientais; (...)

V - controle e zoneamento das atividades potencial ou efetivamente poluidoras; (...)

VIII - recuperação de áreas degradadas;

IX - proteção de áreas ameaçadas de degradação; (...)

Artigo 9. São instrumentos da Política Nacional do Meio Ambiente:

I - o estabelecimento de padrões de qualidade ambiental;

II - o zoneamento ambiental; 
III - a avaliação de impactos ambientais;

IV - o licenciamento e a revisão de atividades efetiva ou potencialmente poluidoras;

V - os incentivos à produção e instalação de equipamentos e a criação ou absorção de tecnologia, voltados para a melhoria da qualidade ambiental;

VI - a criação de espaços territoriais especialmente protegidos pelo Poder Público federal, estadual e municipal, tais como áreas de proteção ambiental, de relevante interesse ecológico e reservas extrativistas; (Redação dada pela Lei no 7.804, de 1989)

VII - o sistema nacional de informações sobre o meio ambiente; (...)

\section{Constituição da República Federativa do Brasil de 1988}

Artigo 182. A política de desenvolvimento urbano, executada pelo Poder Público municipal, conforme diretrizes gerais fixadas em lei, tem por objetivo ordenar o pleno desenvolvimento das funções sociais da cidade e garantir o bem- estar de seus habitantes.

§ 1‥ O plano diretor, aprovado pela Câmara Municipal, obrigatório para cidades com mais de vinte mil habitantes, é o instrumento básico da política de desenvolvimento e de expansão urbana.

§ 20. A propriedade urbana cumpre sua função social quando atende às exigências fundamentais de ordenação da cidade expressas no plano diretor. (...)

Artigo 225. Todos têm direito ao meio ambiente ecologicamente equilibrado, bem de uso comum do povo e essencial à sadia qualidade de vida, impondo-se ao Poder Público e à coletividade o dever de defendê-lo e preservá-lo para as presentes e futuras gerações.

$\S 1$. Para assegurar a efetividade desse direito, incumbe ao Poder Público:

I - preservar e restaurar os processos ecológicos essenciais e prover o manejo ecológico das espécies e ecossistemas; (...)

III - definir, em todas as unidades da Federação, espaços territoriais e seus componentes a serem especialmente protegidos, sendo a alteração e a supressão permitidas somente através de lei, vedada qualquer utilização que comprometa a integridade dos atributos que justifiquem sua proteção; 
IV - exigir, na forma da lei, para instalação de obra ou atividade potencialmente causadora de significativa degradação do meio ambiente, estudo prévio de impacto ambiental, a que se dará publicidade;

V - controlar a produção, a comercialização e o emprego de técnicas, métodos e substâncias que comportem risco para a vida, a qualidade de vida e o meio ambiente; (...)

\section{Lei no. 9.433, de 8 de janeiro de 1997}

Institui a Política Nacional de Recursos Hídricos, cria o Sistema Nacional de Gerenciamento de Recursos Hídricos (...).

Artigo 1‥ A Política Nacional de Recursos Hídricos baseia-se nos seguintes fundamentos:

I - a água é um bem de domínio público; (...)

V - a bacia hidrográfica é a unidade territorial para implementação da Política Nacional de Recursos Hídricos e atuação do Sistema Nacional de Gerenciamento de Recursos Hídricos;

VI - a gestão dos recursos hídricos deve ser descentralizada e contar com a participação do Poder Público, dos usuários e das comunidades.

Artigo 2‥ São objetivos da Política Nacional de Recursos Hídricos: (...)

III - a prevenção e a defesa contra eventos hidrológicos críticos de origem natural ou decorrentes do uso inadequado dos recursos naturais.

Artigo 3‥ Constituem diretrizes gerais de ação para implementação da Política Nacional de Recursos Hídricos: (...)

V - a articulação da gestão de recursos hídricos com a do uso do solo; (...)

Artigo 6o. Os Planos de Recursos Hídricos são planos diretores que visam a fundamentar e orientar a implementação da Política Nacional de Recursos Hídricos e o gerenciamento dos recursos hídricos.

Artigo 7‥ Os Planos de Recursos Hídricos são planos de longo prazo, com horizonte de planejamento compatível com o período de implantação de seus programas e projetos e terão o seguinte conteúdo mínimo: (...)

II - análise de alternativas de crescimento demográfico, de evolução de atividades produtivas e de modificações dos padrões de ocupação do solo; (...) 
$\mathbf{X}$ - propostas para a criação de áreas sujeitas a restrição de uso, com vistas à proteção dos recursos hídricos.

Artigo 8‥ Os Planos de Recursos Hídricos serão elaborados por bacia hidrográfica, por Estado e para o País.

Artigo 31․ Na implementação da Política Nacional de Recursos Hídricos, os Poderes Executivos do Distrito Federal e dos municípios promoverão a integração das políticas locais de saneamento básico, de uso, ocupação e conservação do solo e de meio ambiente com as políticas federal e estaduais de recursos hídricos.

\section{Lei no. 9.985, de 18 de julho de 2000}

(...) institui o Sistema Nacional de Unidades de Conservação da Natureza e dá outras providências.

Artigo 2‥ Para os fins previstos nesta Lei, entende-se por:

I - unidade de conservação: espaço territorial e seus recursos ambientais, incluindo as águas jurisdicionais, com características naturais relevantes, legalmente instituído pelo Poder Público, com objetivos de conservação e limites definidos, sob regime especial de administração, ao qual se aplicam garantias adequadas de proteção; (...)

VI - proteção integral: manutenção dos ecossistemas livres de alterações causadas por interferência humana, admitido apenas o uso indireto dos seus atributos naturais; (...)

XI - uso sustentável: exploração do ambiente de maneira a garantir a perenidade dos recursos ambientais renováveis e dos processos ecológicos, mantendo a biodiversidade e os demais atributos ecológicos, de forma socialmente justa e economicamente viável; (...)

XVI - zoneamento: definição de setores ou zonas em uma unidade de conservação com objetivos de manejo e normas específicos, com o propósito de proporcionar os meios e as condições para que todos os objetivos da unidade possam ser alcançados de forma harmônica e eficaz;

XVII - plano de manejo: documento técnico mediante o qual, com fundamento nos objetivos gerais de uma unidade de conservação, se estabelece o seu zoneamento e as normas que devem presidir o uso da área e o manejo dos recursos naturais, inclusive a implantação das estruturas físicas necessárias à gestão da unidade; (...) 
Artigo 7‥ As unidades de conservação integrantes do SNUC dividem-se em dois grupos, com características específicas:

I - Unidades de Proteção Integral;

II - Unidades de Uso Sustentável. (...)

§ 2․ O objetivo básico das Unidades de Uso Sustentável é compatibilizar a conservação da natureza com o uso sustentável de parcela dos seus recursos naturais.

Artigo 14\%. Constituem o Grupo das Unidades de Uso Sustentável as seguintes categorias de unidade de conservação:

I - Área de Proteção Ambiental; (...)

Artigo 15․ A Área de Proteção Ambiental é uma área em geral extensa, com um certo grau de ocupação humana, dotada de atributos abióticos, bióticos, estéticos ou culturais especialmente importantes para a qualidade de vida e o bem-estar das populações humanas, e tem como objetivos básicos proteger a diversidade biológica, disciplinar o processo de ocupação e assegurar a sustentabilidade do uso dos recursos naturais.

§ 1‥ A Área de Proteção Ambiental é constituída por terras públicas ou privadas.

$\S 2$ 2. Respeitados os limites constitucionais, podem ser estabelecidas normas e restrições para a utilização de uma propriedade privada localizada em uma Área de Proteção Ambiental. (...)

Artigo 27‥ As unidades de conservação devem dispor de um Plano de Manejo.

§ 1‥ O Plano de Manejo deve abranger a área da unidade de conservação, sua zona de amortecimento e os corredores ecológicos, incluindo medidas com o fim de promover sua integração à vida econômica e social das comunidades vizinhas.

§ 2․ Na elaboração, atualização e implementação do Plano de Manejo das Reservas Extrativistas, das Reservas de Desenvolvimento Sustentável, das Áreas de Proteção Ambiental e, quando couber, das Florestas Nacionais e das Áreas de Relevante Interesse Ecológico, será assegurada a ampla participação da população residente.

§ 3‥ O Plano de Manejo de uma unidade de conservação deve ser elaborado no prazo de cinco anos a partir da data de sua criação. (...)

Artigo 28‥ São proibidas, nas unidades de conservação, quaisquer alterações, atividades ou modalidades de utilização em desacordo com os seus objetivos, o seu Plano de Manejo e seus regulamentos. (...) 


\section{Lei no. 10.257 de 10 de julho de 2001}

Regulamenta os artigos. 182 e 183 da Constituição Federal, estabelece diretrizes gerais da política urbana e dá outras providências. (Estatuto das Cidades)

Artigo 2‥ A política urbana tem por objetivo ordenar o pleno desenvolvimento das funções sociais da cidade e da propriedade urbana, mediante as seguintes diretrizes gerais: (...)

III - cooperação entre os governos, a iniciativa privada e os demais setores da sociedade no processo de urbanização, em atendimento ao interesse social;

IV - planejamento do desenvolvimento das cidades, da distribuição espacial da população e das atividades econômicas do Município e do território sob sua área de influência, de modo a evitar e corrigir as distorções do crescimento urbano e seus efeitos negativos sobre o meio ambiente; (...)

VI - ordenação e controle do uso do solo, de forma a evitar: (...)

h) a exposição da população a riscos de desastres. (Incluído dada pela Lei no 12.608, de 2012) (...)

Artigo 4․ Para os fins desta Lei, serão utilizados, entre outros instrumentos:

I - planos nacionais, regionais e estaduais de ordenação do território e de desenvolvimento econômico e social;

II - planejamento das regiões metropolitanas, aglomerações urbanas e microrregiões;

III - planejamento municipal, em especial:

a) plano diretor;

b) disciplina do parcelamento, do uso e da ocupação do solo;

c) zoneamento ambiental;

d) plano plurianual;

e) diretrizes orçamentárias e orçamento anual;

f) gestão orçamentária participativa;

g) planos, programas e projetos setoriais;

h) planos de desenvolvimento econômico e social; (...)

Artigo 40․ O plano diretor, aprovado por lei municipal, é o instrumento básico da política de desenvolvimento e expansão urbana. 
§ 1․ O plano diretor é parte integrante do processo de planejamento municipal, devendo o plano plurianual, as diretrizes orçamentárias e o orçamento anual incorporar as diretrizes e as prioridades nele contidas.

§ 2‥ O plano diretor deverá englobar o território do Município como um todo.

§ 3‥ A lei que instituir o plano diretor deverá ser revista, pelo menos, a cada dez anos. (...)

Artigo 41․ O plano diretor é obrigatório para cidades:

I - com mais de vinte mil habitantes; (...)

VI - incluídas no cadastro nacional de Municípios com áreas suscetíveis à ocorrência de deslizamentos de grande impacto, inundações bruscas ou processos geológicos ou hidrológicos correlatos. (Incluído pela Lei no 12.608, de 2012) (...)

Artigo 42․ O plano diretor deverá conter no mínimo:

I - a delimitação das áreas urbanas onde poderá ser aplicado o parcelamento, edificação ou utilização compulsórios, considerando a existência de infraestrutura e de demanda para utilização, na forma do Artigo 50 desta Lei; (...)

Artigo 42-A. Além do conteúdo previsto no Artigo 42, o plano diretor dos Municípios incluídos no cadastro nacional de municípios com áreas suscetíveis à ocorrência de deslizamentos de grande impacto, inundações bruscas ou processos geológicos ou hidrológicos correlatos deverá conter: (Incluído pela Lei nº 12.608, de 2012)

I - parâmetros de parcelamento, uso e ocupação do solo, de modo a promover a diversidade de usos e a contribuir para a geração de emprego e renda; (Incluído pela Lei no 12.608, de 2012)

II - mapeamento contendo as áreas suscetíveis à ocorrência de deslizamentos de grande impacto, inundações bruscas ou processos geológicos ou hidrológicos correlatos; (Incluído pela Lei no 12.608 , de 2012)

III - planejamento de ações de intervenção preventiva e realocação de população de áreas de risco de desastre; (Incluído pela Lei no 12.608, de 2012)

IV - medidas de drenagem urbana necessárias à prevenção e à mitigação de impactos de desastres; e (Incluído pela Lei no 12.608, de 2012)

V - diretrizes para a regularização fundiária de assentamentos urbanos irregulares, se houver, observadas a Lei ㄲo. 11.977, de 7 de julho de 2009, e demais normas federais e estaduais pertinentes, e previsão de áreas para habitação de interesse social por meio da demarcação de zonas especiais de interesse social e 
de outros instrumentos de política urbana, onde o uso habitacional for permitido. (Incluído pela Lei no 12.608, de 2012)

$\S 1$ 1․ A identificação e o mapeamento de áreas de risco levarão em conta as cartas geotécnicas. (Incluído pela Lei no 12.608, de 2012)

§ 2‥ O conteúdo do plano diretor deverá ser compatível com as disposições insertas nos planos de recursos hídricos, formulados consoante a Lei ํㅜ. 9.433, de 8 de janeiro de 1997. (Incluído pela Lei no 12.608, de 2012) (...)

Artigo 42-B. Os Municípios que pretendam ampliar o seu perímetro urbano após a data de publicação desta Lei deverão elaborar projeto específico que contenha, no mínimo: (Incluído pela Lei no 12.608, de 2012)

I - demarcação do novo perímetro urbano; (Incluído pela Lei no 12.608, de 2012)

II - delimitação dos trechos com restrições à urbanização e dos trechos sujeitos a controle especial em função de ameaça de desastres naturais; (Incluído pela Lei $n^{\circ}$ 12.608, de 2012) (...)

\section{Lei no. 11.445, de 5 de janeiro de 2007}

Estabelece diretrizes nacionais para o saneamento básico (...)

Artigo 2‥ Os serviços públicos de saneamento básico serão prestados com base nos seguintes princípios fundamentais: (...)

IV - disponibilidade, em todas as áreas urbanas, de serviços de drenagem e de manejo das águas pluviais adequados à saúde pública e à segurança da vida e do patrimônio público e privado; (...)

Artigo 3‥ Para os efeitos desta Lei, considera-se:

I - saneamento básico: conjunto de serviços, infraestruturas e instalações operacionais de: (...)

d) drenagem e manejo das águas pluviais urbanas: conjunto de atividades, infraestruturas e instalações operacionais de drenagem urbana de águas pluviais, de transporte, detenção ou retenção para o amortecimento de vazões de cheias, tratamento e disposição final das águas pluviais drenadas nas áreas urbanas; (...)

Artigo 29‥ Os serviços públicos de saneamento básico terão a sustentabilidade econômico-financeira assegurada, sempre que possível, mediante remuneração pela cobrança dos serviços: (...) 
III - de manejo de águas pluviais urbanas: na forma de tributos, inclusive taxas, em conformidade com o regime de prestação do serviço ou de suas atividades. (...)

Artigo 48‥ A União, no estabelecimento de sua política de saneamento básico, observará as seguintes diretrizes: (...)

$\mathbf{X}$ - adoção da bacia hidrográfica como unidade de referência para o planejamento de suas ações; (...)

\section{Lei no. 12.340, de 1ㅇ de dezembro de 2010}

Dispõe sobre as transferências de recursos da União (...) para a execução de ações de resposta e recuperação nas áreas atingidas por desastre (...) / Dispõe sobre o Sistema Nacional de Defesa Civil - SINDEC

Artigo 3--A. O Governo Federal instituirá cadastro nacional de municípios com áreas suscetíveis à ocorrência de deslizamentos de grande impacto, inundações bruscas ou processos geológicos ou hidrológicos correlatos, conforme regulamento. (Incluído pela Lei no 12.608, de 2012)

§ 1‥ A inscrição no cadastro previsto no caput dar-se-á por iniciativa do Município ou mediante indicação dos demais entes federados, observados os critérios e procedimentos previstos em regulamento.

§ 2‥ Os Municípios incluídos no cadastro deverão:

I - elaborar mapeamento contendo as áreas suscetíveis à ocorrência de deslizamentos de grande impacto, inundações bruscas ou processos geológicos ou hidrológicos correlatos;

II - elaborar Plano de Contingência de Proteção e Defesa Civil e instituir órgãos municipais de defesa civil, de acordo com os procedimentos estabelecidos pelo órgão central do Sistema Nacional de Proteção e Defesa Civil - SINPDEC;

III - elaborar plano de implantação de obras e serviços para a redução de riscos de desastre;

IV - criar mecanismos de controle e fiscalização para evitar a edificação em áreas suscetíveis à ocorrência de deslizamentos de grande impacto, inundações bruscas ou processos geológicos ou hidrológicos correlatos; e

V - elaborar carta geotécnica de aptidão à urbanização, estabelecendo diretrizes urbanísticas voltadas para a segurança dos novos parcelamentos do solo e para o aproveitamento de agregados para a construção civil. 
§ 3‥ A União e os Estados, no âmbito de suas competências, apoiarão os Municípios na efetivação das medidas previstas no $\S 2^{\circ}$.

§ 4․ Sem prejuízo das ações de monitoramento desenvolvidas pelos Estados e Municípios, o Governo Federal publicará, periodicamente, informações sobre a evolução das ocupações em áreas suscetíveis à ocorrência de deslizamentos de grande impacto, inundações bruscas ou processos geológicos ou hidrológicos correlatos nos Municípios constantes do cadastro. (...)

§ 6‥ O Plano de Contingência de Proteção e Defesa Civil será elaborado no prazo de 1 (um) ano, sendo submetido a avaliação e prestação de contas anual, por meio de audiência pública, com ampla divulgação. (Artigo acrescido pela Medida Provisória no 547, de 11/10/2011, com redação dada pela Lei no 12.608, de 10/4/2012)

Artigo 3--B. Verificada a existência de ocupações em áreas suscetíveis à ocorrência de deslizamentos de grande impacto, inundações bruscas ou processos geológicos ou hidrológicos correlatos, o município adotará as providências para redução do risco, dentre as quais, a execução de plano de contingência e de obras de segurança e, quando necessário, a remoção de edificações e o reassentamento dos ocupantes em local seguro. (Incluído pela Lei no 12.608, de 2012)

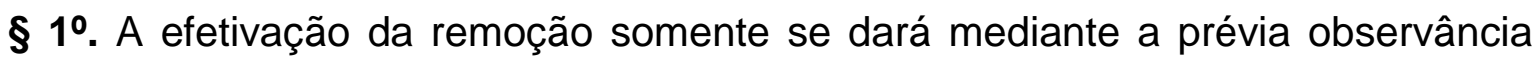
dos seguintes procedimentos:

I - realização de vistoria no local e elaboração de laudo técnico que demonstre os riscos da ocupação para a integridade física dos ocupantes ou de terceiros; e

II - notificação da remoção aos ocupantes acompanhada de cópia do laudo técnico e, quando for o caso, de informações sobre as alternativas oferecidas pelo poder público para assegurar seu direito à moradia.

§ 2. Na hipótese de remoção de edificações, deverão ser adotadas medidas que impeçam a reocupação da área.

$\S 3$. Aqueles que tiverem suas moradias removidas deverão ser abrigados, quando necessário, e cadastrados pelo Município para garantia de atendimento habitacional em caráter definitivo, de acordo com os critérios dos programas públicos de habitação de interesse social. (Artigo acrescido pela Medida Provisória $n^{\circ}$ 547, de 11/10/2011, com redação dada pela Lei no 12.608, de 10/4/2012) 


\section{Lei n․ 12.608, de 10 de abril de 2012}

Institui a Política Nacional de Proteção e Defesa Civil - PNPDEC; dispõe sobre o Sistema Nacional de Proteção e Defesa Civil - SINPDEC e o Conselho Nacional de Proteção e Defesa Civil - CONPDEC; autoriza a criação de sistema de informações e monitoramento de desastres (...)

Artigo 2‥ É dever da União, dos Estados, do Distrito Federal e dos Municípios adotar as medidas necessárias à redução dos riscos de desastre.

§ 1․ As medidas previstas no caput poderão ser adotadas com a colaboração de entidades públicas ou privadas e da sociedade em geral.

§ 2‥ A incerteza quanto ao risco de desastre não constituirá óbice para a adoção das medidas preventivas e mitigadoras da situação de risco.

Artigo 3‥ A PNPDEC abrange as ações de prevenção, mitigação, preparação, resposta e recuperação voltadas à proteção e defesa civil.

Parágrafo único. A PNPDEC deve integrar-se às políticas de ordenamento territorial, desenvolvimento urbano, saúde, meio ambiente, mudanças climáticas, gestão de recursos hídricos, geologia, infraestrutura, educação, ciência e tecnologia e às demais políticas setoriais, tendo em vista a promoção do desenvolvimento sustentável.

Artigo 4․ São diretrizes da PNPDEC:

I - atuação articulada entre a União, os Estados, o Distrito Federal e os Municípios para redução de desastres e apoio às comunidades atingidas;

II - abordagem sistêmica das ações de prevenção, mitigação, preparação, resposta e recuperação;

III - a prioridade às ações preventivas relacionadas à minimização de desastres;

IV - adoção da bacia hidrográfica como unidade de análise das ações de prevenção de desastres relacionados a corpos d'água;

V - planejamento com base em pesquisas e estudos sobre áreas de risco e incidência de desastres no território nacional; (...)

Artigo 5․ São objetivos da PNPDEC:

I - reduzir os riscos de desastres;

II - prestar socorro e assistência às populações atingidas por desastres;

III - recuperar as áreas afetadas por desastres; 
IV - incorporar a redução do risco de desastre e as ações de proteção e defesa civil entre os elementos da gestão territorial e do planejamento das políticas setoriais;

V - promover a continuidade das ações de proteção e defesa civil;

VI - estimular o desenvolvimento de cidades resilientes e os processos sustentáveis de urbanização;

VII - promover a identificação e avaliação das ameaças, suscetibilidades e vulnerabilidades a desastres, de modo a evitar ou reduzir sua ocorrência;

VIII - monitorar os eventos meteorológicos, hidrológicos, geológicos, biológicos, nucleares, químicos e outros potencialmente causadores de desastres;

IX - produzir alertas antecipados sobre a possibilidade de ocorrência de desastres naturais;

$\mathbf{X}$ - estimular o ordenamento da ocupação do solo urbano e rural, tendo em vista sua conservação e a proteção da vegetação nativa, dos recursos hídricos e da vida humana;

XI - combater a ocupação de áreas ambientalmente vulneráveis e de risco e promover a realocação da população residente nessas áreas;

XII - estimular iniciativas que resultem na destinação de moradia em local seguro;

XIII - desenvolver consciência nacional acerca dos riscos de desastre;

XIV - orientar as comunidades a adotar comportamentos adequados de prevenção e de resposta em situação de desastre e promover a autoproteção; e

XV - integrar informações em sistema capaz de subsidiar os órgãos do SINPDEC na previsão e no controle dos efeitos negativos de eventos adversos sobre a população, os bens e serviços e o meio ambiente.

Artigo 6‥ Compete à União:

I - expedir normas para implementação e execução da PNPDEC;

II - coordenar o SINPDEC, em articulação com os Estados, o Distrito Federal e os Municípios;

III - promover estudos referentes às causas e possibilidades de ocorrência de desastres de qualquer origem, sua incidência, extensão e consequência;

IV - apoiar os Estados, o Distrito Federal e os Municípios no mapeamento das áreas de risco, nos estudos de identificação de ameaças, suscetibilidades, vulnerabilidades e risco de desastre e nas demais ações de prevenção, mitigação, preparação, resposta e recuperação; 
V - instituir e manter sistema de informações e monitoramento de desastres;

VI - instituir e manter cadastro nacional de municípios com áreas suscetíveis à ocorrência de deslizamentos de grande impacto, inundações bruscas ou processos geológicos ou hidrológicos correlatos;

VII - instituir e manter sistema para declaração e reconhecimento de situação de emergência ou de estado de calamidade pública;

VIII - instituir o Plano Nacional de Proteção e Defesa Civil;

IX - realizar o monitoramento meteorológico, hidrológico e geológico das áreas de risco, bem como dos riscos biológicos, nucleares e químicos, e produzir alertas sobre a possibilidade de ocorrência de desastres, em articulação com os Estados, o Distrito Federal e os Municípios;

$\mathbf{X}$ - estabelecer critérios e condições para a declaração e o reconhecimento de situações de emergência e estado de calamidade pública;

XI - incentivar a instalação de centros universitários de ensino e pesquisa sobre desastres e de núcleos multidisciplinares de ensino permanente e a distância, destinados à pesquisa, extensão e capacitação de recursos humanos, com vistas no gerenciamento e na execução de atividades de proteção e defesa civil;

XII - fomentar a pesquisa sobre os eventos deflagradores de desastres; $e$

XIII - apoiar a comunidade docente no desenvolvimento de material didáticopedagógico relacionado ao desenvolvimento da cultura de prevenção de desastres.

§ 1‥ O Plano Nacional de Proteção e Defesa Civil conterá, no mínimo:

I - a identificação dos riscos de desastres nas regiões geográficas e grandes bacias hidrográficas do País; e

II - as diretrizes de ação governamental de proteção e defesa civil no âmbito nacional e regional, em especial quanto à rede de monitoramento meteorológico, hidrológico e geológico e dos riscos biológicos, nucleares e químicos e à produção de alertas antecipados das regiões com risco de desastres. (...)

Artigo 7․ Compete aos Estados:

I - executar a PNPDEC em seu âmbito territorial;

II - coordenar as ações do SINPDEC em articulação com a União e os Municípios;

III - instituir o Plano Estadual de Proteção e Defesa Civil;

IV - identificar e mapear as áreas de risco e realizar estudos de identificação de ameaças, suscetibilidades e vulnerabilidades, em articulação com a União e os Municípios; 
V - realizar o monitoramento meteorológico, hidrológico e geológico das áreas de risco, em articulação com a União e os Municípios;

VI - apoiar a União, quando solicitado, no reconhecimento de situação de emergência e estado de calamidade pública;

VII - declarar, quando for o caso, estado de calamidade pública ou situação de emergência; e

VIII - apoiar, sempre que necessário, os Municípios no levantamento das áreas de risco, na elaboração dos Planos de Contingência de Proteção e Defesa Civil e na divulgação de protocolos de prevenção e alerta e de ações emergenciais.

Parágrafo único. O Plano Estadual de Proteção e Defesa Civil conterá, no mínimo:

I - a identificação das bacias hidrográficas com risco de ocorrência de desastres; e

II - as diretrizes de ação governamental de proteção e defesa civil no âmbito estadual, em especial no que se refere à implantação da rede de monitoramento meteorológico, hidrológico e geológico das bacias com risco de desastre.

Artigo 8․ Compete aos Municípios:

I - executar a PNPDEC em âmbito local;

II - coordenar as ações do SINPDEC no âmbito local, em articulação com a União e os Estados;

III - incorporar as ações de proteção e defesa civil no planejamento municipal;

IV - identificar e mapear as áreas de risco de desastres;

V - promover a fiscalização das áreas de risco de desastre e vedar novas ocupações nessas áreas;

VI - declarar situação de emergência e estado de calamidade pública;

VII - vistoriar edificações e áreas de risco e promover, quando for o caso, a intervenção preventiva e a evacuação da população das áreas de alto risco ou das edificações vulneráveis; (...)

IX - manter a população informada sobre áreas de risco e ocorrência de eventos extremos, bem como sobre protocolos de prevenção e alerta e sobre as ações emergenciais em circunstâncias de desastres; (...)

XIII - proceder à avaliação de danos e prejuízos das áreas atingidas por desastres; 
XIV - manter a União e o Estado informados sobre a ocorrência de desastres e as atividades de proteção civil no Município; (...)

Artigo 9․ Compete à União, aos Estados e aos Municípios:

I - desenvolver cultura nacional de prevenção de desastres, destinada ao desenvolvimento da consciência nacional acerca dos riscos de desastre no País;

II - estimular comportamentos de prevenção capazes de evitar ou minimizar a ocorrência de desastres; (...)

IV - estabelecer medidas preventivas de segurança contra desastres em escolas e hospitais situados em áreas de risco;

V - oferecer capacitação de recursos humanos para as ações de proteção e defesa civil; e

VI - fornecer dados e informações para o sistema nacional de informações e monitoramento de desastres.

Artigo 13\%. Fica autorizada a criação de sistema de informações de monitoramento de desastres, em ambiente informatizado, que atuará por meio de base de dados compartilhada entre os integrantes do SINPDEC visando ao oferecimento de informações atualizadas para prevenção, mitigação, alerta, resposta e recuperação em situações de desastre em todo o território nacional.

Artigo 14\%. Os programas habitacionais da União, dos Estados, do Distrito Federal e dos Municípios devem priorizar a relocação de comunidades atingidas e de moradores de áreas de risco.

\section{Lei no. 12.651, de 25 de maio de 2012}

Dispõe sobre a proteção da vegetação nativa; (...) revoga a Lei no. 4.771, de 15 de setembro de 1965 (...) / Novo Código Florestal

Artigo 3‥ Para os efeitos desta Lei, entende-se por: (...)

II - Área de Preservação Permanente - APP: área protegida, coberta ou não por vegetação nativa, com a função ambiental de preservar os recursos hídricos, a paisagem, a estabilidade geológica e a biodiversidade, facilitar o fluxo gênico de fauna e flora, proteger o solo e assegurar o bem-estar das populações humanas; (...)

XIX - leito regular: a calha por onde correm regularmente as águas do curso d'água durante $\mathrm{o}$ ano;(...) 
Artigo 4․ Considera-se Área de Preservação Permanente, em zonas rurais ou urbanas, para os efeitos desta Lei:

I - as faixas marginais de qualquer curso d'água natural, desde a borda da calha do leito regular, em largura mínima de:

a) 30 (trinta) metros, para os cursos d'água de menos de 10 (dez) metros de largura;

b) 50 (cinquenta) metros, para os cursos d'água que tenham de 10 (dez) a 50 (cinquenta) metros de largura;

c) 100 (cem) metros, para os cursos d'água que tenham de 50 (cinquenta) a 200 (duzentos) metros de largura;

d) 200 (duzentos) metros, para os cursos d'água que tenham de 200 (duzentos) a 600 (seiscentos) metros de largura;

e) 500 (quinhentos) metros, para os cursos d'água que tenham largura superior a 600 (seiscentos) metros;

II - as áreas no entorno dos lagos e lagoas naturais, em faixa com largura mínima de:

a) 100 (cem) metros, em zonas rurais, exceto para o corpo d'água com até 20 (vinte) hectares de superfície, cuja faixa marginal será de 50 (cinquenta) metros;

b) 30 (trinta) metros, em zonas urbanas; (...)

$\S$ 9․ Em áreas urbanas, assim entendidas as áreas compreendidas nos perímetros urbanos definidos por lei municipal, e nas regiões metropolitanas e aglomerações urbanas, as faixas marginais de qualquer curso d'água natural que delimitem as áreas da faixa de passagem de inundação terão sua largura determinada pelos respectivos Planos Diretores e Leis de Uso do Solo, ouvidos os Conselhos Estaduais e Municipais de Meio Ambiente, sem prejuízo dos limites estabelecidos pelo inciso I do caput. (Incluído pela Medida Provisória no 571, de 2012)

§ 10․ No caso de áreas urbanas, assim entendidas as compreendidas nos perímetros urbanos definidos por lei municipal, e nas regiões metropolitanas e aglomerações urbanas, observar-se-á o disposto nos respectivos Planos Diretores e Leis Municipais de Uso do Solo, sem prejuízo do disposto nos incisos do caput. (Incluído pela Medida Provisória no 571, de 2012)

Artigo 6‥ Consideram-se, ainda, de preservação permanente, quando declaradas de interesse social por ato do Chefe do Poder Executivo, as áreas cobertas com 
florestas ou outras formas de vegetação destinadas a uma ou mais das seguintes finalidades:

I - conter a erosão do solo e mitigar riscos de enchentes e deslizamentos de terra e de rocha; (...)

III - proteger várzeas; (...)

Artigo 7‥ A vegetação situada em Área de Preservação Permanente deverá ser mantida pelo proprietário da área, possuidor ou ocupante a qualquer título, pessoa física ou jurídica, de direito público ou privado. (...)

Artigo 8․ A intervenção ou a supressão de vegetação nativa em Área de Preservação Permanente somente ocorrerá nas hipóteses de utilidade pública, de interesse social ou de baixo impacto ambiental previstas nesta Lei. (...)

Artigo 9․ É permitido o acesso de pessoas e animais às Áreas de Preservação Permanente para obtenção de água e para realização de atividades de baixo impacto ambiental.

\section{Legislação estadual}

\section{Lei Estadual no 5.280, de 4 de setembro de 1986}

Declara área de proteção ambiental a região que circunda a represa hidrelétrica do Bairro da Usina, no Município de Atibaia.

Artigo 1‥ Fica declarada área de proteção ambiental a região que circunda a represa hidroelétrica do Bairro de Usina, no Município de Atibaia.

Artigo 3‥ $\mathrm{Na}$ implantação da área de proteção ambiental serão aplicadas as medidas previstas na legislação e poderão ser celebrados convênios visando evitar ou impedir o exercício de atividades causadoras de degradação da qualidade ambiental.

Parágrafo único. Tais medidas procurarão impedir especialmente:

1 - a implantação de atividades potencialmente poluidoras, capazes de afetar mananciais de águas, o solo e o ar;

2 - a realização de obras de terraplanagem e a abertura de canais que importem em sensível alteração das condições ecológicas, principalmente na zona de vida silvestre; 
3 - o exercício da atividade capazes de provocar acelerada erosão das terras ou acentuado assoreamento nas coleções hídricas;

4 - o exercício de atividades que ameacem extinguir as espécies raras de flora e de fauna locais.

Artigo 4\%. Fica estabelecida uma zona de vida silvestre abrangendo todos os remanescentes da flora original existente nesta área de proteção ambiental e as áreas definidas como de preservação permanente, pelo Código Florestal.

\section{Constituição do Estado de São Paulo de 1989}

Artigo 205\%. O Estado instituirá, por lei, sistema integrado de gerenciamento dos recursos hídricos, congregando órgãos estaduais e municipais e a sociedade civil, e assegurará meios financeiros e institucionais para: (...)

IV - a defesa contra eventos críticos, que ofereçam riscos à saúde e segurança públicas e prejuízos econômicos ou sociais; (...)

Artigo 210. Para proteger e conservar as águas e prevenir seus efeitos adversos, o Estado incentivará a adoção, pelos Municípios, de medidas no sentido: (...)

II - do zoneamento de áreas inundáveis, com restrições a usos incompatíveis nas sujeitas a inundações frequentes e da manutenção da capacidade de infiltração do solo;

III - da implantação de sistemas de alerta e defesa civil, para garantir a segurança e a saúde públicas, quando de eventos hidrológicos indesejáveis; (...)

V - da instituição de programas permanentes de racionalização do uso das águas destinadas ao abastecimento público e industrial e à irrigação, assim como de combate às inundações e à erosão. (...)

\section{Lei no. 7.663, de 30 de dezembro de 1991}

Estabelece normas de orientação à Política Estadual de Recursos Hídricos bem como ao Sistema Integrado de Gerenciamento de Recursos Hídricos.

Artigo 3‥ A Política Estadual de Recursos Hídricos atenderá aos seguintes princípios: (...)

II - adoção da bacia hidrográfica como unidade físico-territorial de planejamento e gerenciamento; (...) 
V - combate e prevenção das causas e dos efeitos adversos da poluição, das inundações, das estiagens, da erosão do solo e do assoreamento dos corpos d'água; (...)

VII - compatibilização do gerenciamento dos recursos hídricos com o desenvolvimento regional e com a proteção do meio ambiente.

Artigo. 4․ Por intermédio do Sistema Integrado de Gerenciamento de Recursos Hídricos - SIGRH, O Estado assegurará meios financeiros e institucionais para atendimento do disposto nos artigos 205 a 213 da Constituição Estadual e especialmente para: (...)

IV - defesa contra eventos hidrológicos críticos, que ofereçam riscos à saúde e à segurança públicas assim como prejuízos econômicos e sociais; (...)

Artigo 7‥ O Estado realizará programas conjuntos com os municípios, mediante convênios de mútua cooperação, assistência técnica e econômico-financeira, com vistas a: (...)

II - implantação, conservação e recuperação das áreas de proteção permanente e obrigatória;

III - zoneamento das áreas inundáveis, com restrições a usos incompatíveis nas áreas sujeitas a inundações frequentes e manutenção da capacidade de infiltração do solo;

IV - implantação de sistemas de alerta e defesa civil para garantir a segurança e a saúde públicas, quando de eventos hidrológicos indesejáveis; (...)

VI - combate e prevenção das inundações e da erosão; (...)

Artigo 8․ O Estado, observados os dispositivos constitucionais relativos à matéria, articulará com a União, outros Estados vizinhos e municípios, atuação para o aproveitamento e controle dos recursos hídricos em seu território, inclusive para fins de geração de energia elétrica, levando em conta, principalmente: (...)

II - o controle de cheias, a prevenção de inundações, a drenagem e a correta utilização das várzeas; (...)

\section{Decreto no. 40.151, de 16 de junho de 1995}

Reorganiza o Sistema Estadual de Defesa Civil e dá outras providências

Artigo 3‥ São objetivos do Sistema Estadual de Defesa Civil: 
I - planejar e promover a defesa permanente contra desastres naturais ou provocados pelo homem;

II - atuar na iminência e em situações de desastres;

III - prevenir ou minimizar danos, socorrer e assistir populações atingidas e recuperar áreas afetadas por desastres.

Artigo 9.. Para os efeitos deste decreto, considera-se (...):

VI - Minimização de Desastres: o conjunto de medidas destinadas a:

a) prevenir desastres através da avaliação e redução de riscos, com medidas estruturais e não estruturais;

b) preparação para emergências e desastres com a adoção de programas de desenvolvimento institucional, de recursos humanos, científico e tecnológico, mudança cultural, motivação e articulação empresarial, monitorização - alerta e alarme, planejamento operacional, mobilização e aparelhamento e apoio logístico; (...)

Artigo 12‥ Às Secretarias de Estado, por intermédio de seus órgãos e entidades vinculadas, e em articulação com a Coordenadoria Estadual de Defesa Civil, entre outras atividades, cabe: (...)

II - Secretaria de Recursos Hídricos, Saneamento e Obras:

a) planejar e promover medidas relacionadas com o controle de cheias e inundações, através da monitoração das condições hidrológicas e dos deflúvios das barragens dos sistemas hidrelétricos e das bacias hidrográficas;

b) planejar e promover medidas de defesa contra eventos críticos, que ofereçam riscos à saúde e segurança públicas e prejuízos econômicos ou sociais;

c) incentivar a adoção, pelos Municípios, de medidas para proteger e conservar as águas e prevenir seus efeitos adversos, através:

1. da implantação de sistemas de alerta e defesa civil, para garantir a segurança e a saúde públicas, quando de eventos hidrológicos indesejáveis;

2. do zoneamento de áreas inundáveis, com restrições a usos incompatíveis nas sujeitas a inundações freqüentes e da manutenção da capacidade de infiltração do solo;

d) desenvolver estudos e pesquisas que permitam determinar áreas de riscos, bem como fornecer informações destinadas à orientação das ações da Coordenadoria Estadual de Defesa Civil - CEDEC; 
III - Secretaria de Energia: planejar e promover medidas relacionadas com o controle de cheias e inundações, através da monitoração das condições hidrológicas e dos deflúvios das barragens dos sistemas hidrelétricos e das bacias hidrográficas;

IV - Secretaria do Meio Ambiente:

a) estabelecer normas, critérios e padrões relativos ao combate e à proteção do meio ambiente, ao uso racional de recursos naturais renováveis, com o objetivo de reduzir desastres;

b) promover a educação ambiental e a conscientização pública para a preservação, conservação e recuperação do meio ambiente, tendo como alvo a diminuição e a intensidade dos desastres, riscos e ameaças;

c) desenvolver estudos e pesquisas que permitam determinar áreas de riscos, bem como fornecer informações destinadas à orientação das ações da Coordenadoria Estadual de Defesa Civil - CEDEC; (...)

\section{Lei no. 13.798, de 9 de novembro de 2009}

Institui a Política Estadual de Mudanças Climáticas - PEMC.

Artigo 20. A PEMC tem por objetivo geral estabelecer o compromisso do Estado frente ao desafio das mudanças climáticas globais, dispor sobre as condições para as adaptações necessárias aos impactos derivados das mudanças climáticas, bem como contribuir para reduzir ou estabilizar a concentração dos gases de efeito estufa na atmosfera.

Artigo 3‥ A PEMC atenderá aos seguintes princípios fundamentais:

I - da precaução, pelo qual a ausência de certeza científica não pode ser utilizada como razão para postergar medidas eficazes para prevenir a degradação ambiental quando houver ameaça de danos sérios ou irreversíveis à civilização humana;

II - da prevenção, que consiste na adoção de medidas e políticas públicas capazes de mitigar impactos conhecidos no sistema climático da Terra; (...)

VII - da ação governamental, importante na manutenção do equilíbrio ecológico, considerado o meio ambiente como um patrimônio público a ser necessariamente protegido, tendo em vista sua fruição coletiva, com racionalidade na utilização do solo, do subsolo, da água e do ar, por meio do acompanhamento, pelo Estado, da qualidade ambiental, além do planejamento e da fiscalização do uso sustentável dos recursos naturais; (...) 
Artigo 4‥ Para os fins previstos nesta lei, considerem-se as seguintes definições: (...)

III - aquecimento global: intensificação do efeito estufa natural da atmosfera terrestre, em decorrência de ações antrópicas, responsáveis por emissões e pelo aumento da concentração atmosférica de gases que contribuem para o aumento da temperatura média do planeta, provocando fenômenos climáticos adversos; (...)

XXV - mudança climática: alteração no clima, direta ou indiretamente atribuída à atividade humana, que afete a composição da atmosfera e que se some àquela provocada pela variabilidade climática natural, observada ao longo de períodos comparáveis; (...)

XL - Zoneamento Ecológico-Econômico - ZEE: instrumento básico e referencial para o planejamento ambiental e a gestão do processo de desenvolvimento, capaz de identificar a potencialidade e a vocação de um território, tornando-o base do desenvolvimento sustentável.

Artigo 5․ São objetivos específicos da PEMC: (...)

V - implementar ações de prevenção e adaptação às alterações produzidas pelos impactos das mudanças climáticas, a fim de proteger principalmente os estratos mais vulneráveis da população; (...)

XV - promover um sistema de planejamento urbano sustentável de baixo impacto ambiental e energético, inclusive a identificação, estudo de suscetibilidade e proteção de áreas de vulnerabilidade indireta quanto à ocupação desordenada do território.

Artigo 6․ São diretrizes da PEMC: (...)

V - cooperar nos preparativos para a prevenção e adaptação aos impactos da mudança do clima, desenvolver e elaborar planos adequados e integrados para a gestão de zonas costeiras, áreas metropolitanas, recursos hídricos e agricultura, bem como para a proteção e recuperação de regiões particularmente afetadas por secas e inundações; (...)

X - mobilizar a Defesa Civil do Estado, em resposta a eventuais desastres naturais, como deslizamentos e inundações, ou para a proteção de áreas de risco, como encostas e fundos de vale; (...)

Artigo 8‥ A Avaliação Ambiental Estratégica do processo de desenvolvimento setorial deve ter periodicidade quinquenal e analisar de forma sistemática as 
consequências ambientais de políticas, planos e programas públicos e privados, frente aos desafios das mudanças climáticas, dentre outros aspectos considerando:

I - o Zoneamento Ecológico-Econômico, revisto a cada 10 (dez) anos, para disciplinar as atividades produtivas, a racional utilização de recursos naturais, o uso e a ocupação do solo paulista, como base para modelos locais de desenvolvimento sustentável;

II - estratégias aplicáveis àquelas zonas e atividades de maior vulnerabilidade às mudanças climáticas, prováveis impactos e medidas de prevenção e adaptação; (...)

VII - medidas de prevenção e adaptação aos impactos das mudanças do clima; (...)

Artigo 10․ O disciplinamento do uso do solo urbano e rural, dentre outros resultados, buscará:

I - prevenir e evitar a ocupação desordenada de áreas de vulnerabilidade direta e indireta, como o setor costeiro, zonas de encostas e fundos de vale;

II - atenuar os efeitos de desastres de origem climática, prevenir e reduzir os impactos, principalmente sobre áreas de maior vulnerabilidade; (...)

V - ordenar os múltiplos usos da água, permitindo a proteção de recursos hídricos, a gestão compartilhada e racional da água, além de prevenir ou mitigar efeitos de inundações;

VI - integrar a dimensão climática aos planos de macrodrenagem e recursos hídricos;

VII - incorporar as alterações e formas de proteção do microclima no ordenamento territorial urbano, protegendo a vegetação arbórea nativa;

VIII - delimitar, demarcar e recompor com cobertura vegetal áreas de reserva legal e, principalmente, áreas de preservação permanente, matas ciliares, fragmentos e remanescentes florestais;

IX - identificar e mapear as vulnerabilidades existentes nos territórios municipais, como base para políticas locais de adaptação aos impactos decorrentes das mudanças climáticas; (...)

Artigo 12‥ Para os fins do artigo $11^{\circ}$ deverão ser consideradas, dentre outras, as iniciativas nas áreas de: (...)

XI - macrodrenagem e múltiplos usos da água, assegurando a proteção de recursos hídricos, a gestão compartilhada e racional da água, além de prevenir ou mitigar efeitos de inundações; (...) 
Artigo 17․ A Política Estadual de Recursos Hídricos, o Sistema Integrado de Gerenciamento de Recursos Hídricos, o Plano Estadual de Recursos Hídricos, os Planos de Bacias Hidrográficas, os Comitês de Bacia Hidrográfica, o Comitê Coordenador do Plano Estadual de Recursos Hídricos e o Conselho Estadual de Recursos Hídricos devem considerar as mudanças climáticas, a definição das áreas de maior vulnerabilidade e as ações de prevenção, mitigação e adaptação estabelecidas nesta lei.

Artigo 33‥ O Governo do Estado, assumindo sua tarefa no enfrentamento do desafio das mudanças climáticas globais, compromete-se, dentro dos seguintes prazos, após a publicação desta lei, a: (...)

IV - definir os critérios para a Avaliação Ambiental Estratégica e o Zoneamento Econômico-Ecológico em até 6 (seis) meses;

V - implantar a Avaliação Ambiental Estratégica em até 2 (dois) anos;

VI - implantar o Zoneamento Econômico-Ecológico em até 2 (dois) anos; (...)

IX - elaborar um plano participativo de adaptação aos efeitos das mudanças climáticas, contemplando catástrofes de origem climática, em até 2 (dois) anos; (...)

\section{Decreto no 57.512, de 11 de novembro de 2011}

Institui o Programa Estadual de Prevenção de Desastres Naturais e de Redução de Riscos Geológicos e dá providências correlatas

Artigo 1․ Fica instituído o Programa Estadual de Prevenção de Desastres Naturais e de Redução de Riscos Geológicos - PDN.

Artigo 2․ O programa instituído pelo artigo $1^{\circ}$ deste decreto tem por objetivos:

I - promover o diagnóstico atualizado dos perigos e de riscos de escorregamentos, inundações, erosão e colapso de solo, estabelecendo prioridades para mapeamento de áreas de risco existentes no Estado de São Paulo;

II - desenvolver estratégias de planejamento de uso e ocupação do solo, ordenamento territorial e planejamento ambiental, a fim de promover uma adequada ocupação do território;

III - integrar e estimular estratégias para o monitoramento e fiscalização em áreas de risco e em áreas sujeitas a perigos geológicos, para evitar que as áreas se ampliem e que ocorram acidentes danosos; 
IV - sistematizar ações institucionais e procedimentos operacionais para redução, mitigação e erradicação do risco, em sintonia com as políticas em andamento no âmbito das Secretarias de Estado e dos municípios;

V - promover a capacitação e o treinamento de equipes municipais e demais agentes com responsabilidades no gerenciamento de risco, bem como a disseminação da informação e do conhecimento acerca das situações de risco à população, aumentando a percepção e a participação comunitária, na busca de soluções.

Artigo 8․ Do Plano de Trabalho do Programa Estadual de Prevenção de Desastres Naturais e de Redução de Riscos Geológicos - PDN constarão, no mínimo, as seguintes ações:

I - execução de trabalhos de:

a) mapeamento de áreas de riscos e de cartas geotécnicas;

b) construção de sistema informatizado para gerenciamento de dados sobre áreas de risco no Estado;

II - implantação de programas de apoio aos municípios, na prevenção de riscos em seu território, fornecendo base técnica para a adoção de instrumentos complementares, tais como:

a) planos preventivos e de contingência;

b) redução da vulnerabilidade de comunidades;

c) infraestrutura;

d) sistemas de monitoramento e alerta;

e) programas de participação comunitária e de educação para convivência com situações de risco;

III - ampliação e fortalecimento dos planos preventivos e de contingência de defesa civil e da capacitação e treinamento de agentes municipais, para controle de áreas de risco; (...)

V - indicação de recursos técnicos, humanos e financeiros para a elaboração e atualização de dados que subsidiem o conhecimento contínuo da situação de risco no Estado, tais como:

a) a elaboração de cartografia básica de todo o território do Estado;

b) a aquisição periódica de imagens de alta resolução;

c) a manutenção de sistema gerenciador de informações de risco; 
d) suporte à Política Estadual de Mudança Climáticas com base nas ações e programas das diferentes Secretarias de Estado;

VI - proposição de mecanismos de incentivo e de aplicação de instrumentos legais que levem os municípios a cumprir sua responsabilidade no planejamento e ordenamento de seu território, bem como na identificação, monitoramento, controle, prevenção e erradicação de áreas de risco; (...)

\section{Legislação municipal}

\section{Lei Complementar no. 507, de 5 de outubro de 2006}

Dispõe sobre o Plano Diretor da Estância de Atibaia, para o período 2007/ 2016, e dá outras providências.

Artigo 4‥ O Plano Diretor terá vigência de 10 (dez) anos, contados a partir da data de sua publicação no Diário Oficial do Município, devendo, ao final desse prazo, ser substituído por versão revista e atualizada.

Artigo 16․ São diretrizes e proposições gerais relativas ao ambiente físico e infraestrutura as constantes no Anexo A.08 desta Lei Complementar.

Artigo 31․ As diretrizes e proposições para os Serviços e Equipamentos de Infraestrutura constam no Anexo A.18 desta Lei Complementar.

Artigo 34․ As diretrizes e proposições Espaciais constam no Anexo A.20 desta Lei Complementar.

Artigo 36․ Fica instituída, na forma do Anexo A.22 desta Lei Complementar, a POLÍTICA DE MEIO AMBIENTE DA ESTÂNCIA DE ATIBAIA, a ser articulada e implementada pelos esforços e contribuições da Administração municipal, do Poder Público de outros níveis de governo, e da comunidade.

ANEXO A.08. Diretrizes e proposições gerais relativas ao ambiente físico e infraestrutura

NO CAMPO DO MEIO AMBIENTE

6. Áreas especiais de preservação e atratividade ambiental devem merecer tratamento específico na forma de reservas e parques destinados ao desfrute da população e manutenção do equilíbrio com o meio. 
ANEXO A.14. Evolução, situação atual e demandas aos serviços e equipamentos de infraestrutura

1. Sistemas de Saneamento Básico (...)

1.4. Drenagem

a) Gestão

- Unidade encarregada: Secretaria Municipal de Infraestrutura, por seu Departamento de Vias Públicas, Divisão de Obras e Infraestrutura, Setor de Drenagem.

- Sem instrumentos gerais de orientação da ação, a qual se desenvolve empiricamente, em função de demandas identificadas.

b) Sistemas

- Drenagem superficial na maior parte das vias e fundos de vale.

- Drenagem subterrânea em partes específicas do assentamento.

- Não há disponibilidade de cadastramento e traçados dos sistemas. (...)

ANEXO A.18. Serviços e equipamentos de infraestrutura - diretrizes e proposições

NO CAMPO DO SANEAMENTO BÁSICO (...)

3. Para o Setor Drenagem, são estabelecidas as seguintes linhas de diretrizes/proposições:

3.1. Cadastramento sistemático de todas as situações e áreas de ocorrência de enchentes e alagamentos, com a consolidação das soluções adotadas e em curso para atendimento a essas áreas (prevenção de novas ocorrências), podendo envolver o saneamento em cabeceiras, a transposição de bacias, etc.

3.2. Elaboração de Plano geral para o setor, com a consideração das áreas de expansão do tecido urbano contempladas no Plano Diretor, dos assentamentos urbanos isolados, das demandas da área consolidada de maior adensamento.

3.3. Investigação quanto aos valores de precipitação e descargas de águas pluviais, em presença de dados referentes às mudanças climáticas em curso, com revisão dos parâmetros presentemente adotados no planejamento e programação do setor. (...)

ANEXO A.20. Estrutura do assentamento, organização espacial, uso e ocupação do solo - diretrizes e proposições

PARTIDO URBANÍSTICO

\section{Conceito}


As Diretrizes/Proposições referentes ao assentamento urbano e rural, à organização espacial, ao uso e ocupação do solo, no Município, configuram o chamado partido urbanístico, que compreende o conjunto de fundamentos específicos, o teor, e a configuração físico-espacial desses elementos.

Fundamentos (...)

f) Devem ser tidas, também, como elementos de fundamentação do partido, as destinações legais formais de áreas para desenvolvimento (áreas para usos nãoresidenciais ao longo dos eixos rodoviários), e para o exercício de políticas públicas de habitação de interesse social (Zonas Especiais de Interesse Social - ZEIS).

g) No caso das primeiras, que se constituem em elementos de importância estratégica decisiva no aproveitamento dos fatores locacionais presentes (atravessamento do território municipal pelos eixos de integração funcional Região de Campinas/Vale do Paraíba/porto de São Sebastião, regiões metropolitanas de Grande São Paulo e Belo Horizonte, regiões Bragantina e de Jundiaí), foram destinadas faixas de largura variável, medidas para cada lado dos eixos rodoviários (700,0 m, no caso da Via D. Pedro I; 350,00 m, no caso da Via Fernão Dias; 300,00 m, no caso da Via Edgar Máximo Zambotto), para os usos não residenciais, em especial, o industrial. No entanto, o aproveitamento dessas faixas virá condicionado por restrições de mercado (competição em condições desfavoráveis com outros usos, inclusive o residencial), ambientais (presença, no espaço das faixas, de áreas consideradas de Preservação Permanente - as chamadas APP - ou de Áreas de Proteção Ambiental - as chamadas APAs), ou de uso atual. Consideradas tais restrições, é possível identificar-se as seguintes situações no que respeita ao aproveitamento possível das áreas das faixas de desenvolvimento

- áreas de ocupação possível com usos não residenciais, sem maiores condicionamentos,

- áreas de ocupação condicionada por restrições de ordem ambiental (inseridas em delimitações de APAs),

- áreas de ocupação fortemente condicionada por situação atual de uso,

- áreas de ocupação fortemente condicionada por situações de mercado (nas quais os usos não-residenciais competirão em posição altamente desvantajosa em relação aos demais, inclusive os residenciais),

- áreas de ocupação não possível por restrições de ordem ambiental (inseridas em delimitações de APPs). (...) 
Elementos estruturadores:

1. Áreas - Designação e Delimitação

a) Compartimentos ambientais estruturadores

São designados dois compartimentos nesta condição, ambos a serem formalizados como APAs municipais:

- compartimento da Serra de Itapetinga, já em parte objeto de conservação, mediante ato de tombamento do governo estadual (Condephaat); no partido, a área de conservação municipal indicada abrange a maior parte da área tombada, ampliando o espaço de conservação consideravelmente na direção Sul; a delimitação é dada pela cota 900,0 m do nível do mar, acima da qual todas as áreas abrangidas integrarão a APA proposta; tal delimitação incorpora similar que foi definida na legislação de ordenamento do uso e ocupação do solo do Município, na condição de Área de Interesse Ambiental Relevante; a finalidade da instituição dessa APA é a de proteger e conservar o compartimento, de múltiplo significado para Atibaia, seja como elemento de manutenção da flora e fauna regionais, seja como elemento de atração e desfrute turístico, esportivo e panorâmico, seja como referencial simbólico e de identidade do Município; a proposta integrará a Política Municipal de Meio Ambiente;

- compartimento da Várzea do Rio Atibaia (que adentra áreas de bacias de alguns de seus afluentes principais) no trecho desta compreendido na delimitação municipal; de finalidades similares às da APA da Serra, a formalização deste compartimento como área de conservação terá em vista a estabilização das condições hídricas do rio, a observância das restrições correspondentes à condição da várzea como APP, o desenvolvimento do turismo ecológico, e a preservação no Município de espaço verde aberto acessível a todas as partes da urbanização principal; a delimitação indicada segue similar contida na legislação consolidada de ordenamento do uso e ocupação do solo, abrangendo todas as áreas de cota inferior a 745,0 m do nível do mar; esta proposta integra, igualmente, a Política Municipal de Meio Ambiente; dado que parte das áreas abrangidas nesta delimitação encontra-se, já, urbanizada, é previsto tratamento especial para as mesmas, na legislação de ordenamento espacial e ambiental, a ser consolidada e complementada com base nas indicações do presente Plano.

b) Divisão territorial geral 
A divisão do território municipal em áreas urbanas e rurais, tal como, presentemente configurada, é considerada estável, não devendo sofrer alterações no horizonte de vigência do Plano Diretor. Tal determinação tem em vista não ampliar, e, no que possível, reduzir, o grau de designação formal de áreas como urbanas, que tem sido causa de um espraiamento do tecido urbano do Município que se apresenta problemático, por várias razões:

- retira áreas rurais, ainda que indiretamente, do estoque potencialmente disponibilizado para a produção agrícola e agropecuária;

- distende de forma pouco econômica a área para a qual o Poder Público deve levar os serviços e equipamentos, reduzindo o nível de atendimento geral e onerando fortemente as finanças municipais;

- propicia interrupções e pertubações nas unidades de paisagem, o que se mostra altamente contraproducente num Município que tem na atividade turística uma de suas principais vocações de desenvolvimento;

- provoca danos ambientais graves, na medida em que estimula a existência de áreas desprovidas da cobertura vegetal original sem que seja esta substituída, às vezes por longos espaços de tempo, por tratamentos paisagísticos urbanos em condições de assegurar a estabilidade dos terrenos e prevenir o arraste de solo para os corpos d'água. (...)

\section{c) Áreas especializadas}

Nesta categoria, são incluídas as áreas formalmente designadas como de desenvolvimento na legislação corrente do Município, abrangendo os espaços principais destinados à implantação de atividades industriais e similares quanto ao impacto ambiental e urbanístico; parte dessas áreas acha-se, já consolidada nessa condição, estando a parte absolutamente majoritária ainda sem ocupação; na proposta, são considerados os diferentes níveis de aproveitamento possível das áreas da espécie, conforme colocado nos Fundamentos do partido urbanístico. Além das áreas desta primeira categoria, a proposta incorpora como especializadas as áreas dedicadas com exclusividade a atividades turísticas, recreacionais, esportivas e culturais, bem como áreas dedicadas, também com exclusividade, a serviços/equipamentos sociais, de infraestrutura, e municipais. $\mathrm{Na}$ categoria especializadas inclui-se, ainda, as áreas dedicadas a melhorias e inserção urbanísticas de assentamentos precários, ocupadas por população de faixas de 
renda inferiores, e objeto de políticas sociais de habitação (ZEIS), bem como áreas designadas com prioridade a habitação de interesse social.

d) Áreas urbanizadas consolidadas

São abrangidas aqui as áreas parceladas, arruadas ou em processo de arruamento, para fins urbanos, com diferentes graus de ocupação ou ociosidade; em função dessa condição, e das demais funções urbanas a que estão voltadas, tais áreas são classificadas como áreas:

- a manter em seus atuais padrões e condições de urbanização,

- a adensar, podendo-se, para tanto, contar com recurso a instrumentos de política urbana, conforme dispostos no Estatuto da Cidade.

e) Áreas não-urbanizadas compreendidas na delimitação dos perímetros urbanos presentes, considerada como limite das áreas urbanas, enquadradas em três categorias:

- de ocupação preferencial em condições de mercado, podendo comportar empreendimentos de habitação de interesse social,

- de ocupação preferencial em condições de mercado,

- de uso não urbano, nas quais será incentivada a permanência e a estabilidade das atividades produtivas do setor primário.

f) Áreas de Preservação Permanente - APP

É determinada a observância rigorosa das restrições que incidem sobre as áreas de enquadramento possível nesta categoria, segundo o que dispõe o Código Florestal, e conforme recepcionado na legislação municipal vigente de ordenamento espacial. (...)

Áreas de tratamento especial

1. Áreas Objeto de Normas Estaduais de Conservação/Tombamento/Proteção

a) APA Usina (Lei Estadual $n . .5 .280$, de 04 de setembro de 1986).

b) APA do Sistema Cantareira (Lei Estadual n.. 10.111, de 04 de dezembro de 1998).

c) Área Tombada da Serra do Itapetinga (Resolução n. 14, de 06 de julho de 1983 Condephaat).

d) Tombamento do prédio do Museu Municipal (Processo IPHAN n.ำ 0522-T, de 23 de agosto de 1955).

e) Tombamento do casarão Júlia Ferraz (Resolução $n^{\circ}$ 19.554/70, de 07 de fevereiro de 1975 Condephaat). 
2. Áreas Objeto de Normas Municipais de Conservação / Tombamento / /Proteção

a) AIAR - Várzea do Rio Atibaia (Lei Complementar n.ํ 480, de 14 de julho de 2005).

b) AIAR - Serra do Itapetinga (Lei Complementar n. 480, de 14 de julho de 2005).

c) Parque Municipal da Grota Funda (Lei n.. 2.293, de 08 de setembro de 1988).

d) Área de proteção do Rádio Observatório do Itapetinga - INPE (Lei n.․ 1.285, de 19 de abril de 1972).

3. Áreas Indicadas para Tratamento Especial Ligado à Proteção de Mananciais

a) Bacia do Jundiaizinho (trecho compreendido no território de Município); uso para abastecimento já confirmado pela concessionária Sabesp, para atendimento a Municípios da Grande São Paulo vizinhos a Atibaia, com previsão de uso de parte da capacidade para atendimento a este Município - prioridade 1 no tratamento especial.

b) Bacia do Amarais - considerada como possível manancial para atendimento a Atibaia - prioridade 2 no tratamento especial.

4. Área do Centro Histórico

Área já objeto de normatização do uso/ocupação do solo por Lei Complementar (470/05); indicada para planejamento urbanístico específico.

ANEXO A.22. Política de meio ambiente da estância de Atibaia

Diretrizes e proposições da política de meio ambiente

A Política de Meio Ambiente estabelece diretrizes/proposições compreendidas nos seguintes campos, ou linhas de ação/formação de pautas: (...)

d) controle ambiental: (...)

- Os loteamentos já existentes deverão ter prazo para se adequarem em termos de infraestrutura e saneamento; é imperioso que sejam obrigatoriamente cadastrados aos programas municipais e estaduais de recursos hídricos; (...)

e) conservação/preservação/recuperação: (...)

- Viabilizar, através de estudos e projetos, a recuperação das áreas de fundo de vale, com a implantação de parques lineares, com finalidade de proteger os recursos hídricos e ampliar as áreas de lazer habilitadas para a comunidade;

- Definir as áreas locais de interesse ecológico, em consonância com as políticas regionais, destacando-se os estudos de implantação de corredores de fauna e flora; 
- Que todos os empreendimentos, residenciais, industriais, ou de setor terciário, quando for o caso, realizem a reposição de matas ciliares e APPs em suas propriedades, ou, na impossibilidade, em outras áreas pertencentes à mesma bacia hidrográfica;

- Estabelecimento de políticas de implantação de Unidades de Conservação Municipais, arborização e paisagismo urbano;

- Instituir as APAs municipais da várzea do Rio Atibaia e da Serra do Itapetinga, fixando para as mesmas suas respectivas regras de manejo.

- Dar tratamentos especiais de ordenamento de uso e ocupação do solo e meio ambiente às áreas das bacias dos seguintes corpos d' água, associados, respectivamente, a suas finalidades como mananciais:

a. Rio Atibaia, a montante do ponto atual de captação; em uso;

b. Rib. Taboão (Onofre), a montante do ponto atual da captação; em uso;

c. Rib. Jundiaizinho; de uso previsto para abastecimento de municípios da Grande São Paulo vizinhos; em tratativas, derivação de parte do aproveitamento para o abastecimento de Atibaia;

d. Córr. dos Amarais; aproveitamento eventual para abastecimento de Atibaia;

- Diligenciar junto ao Estado com vistas a agilizar a definição das regras de manejo para a APA da Usina.

f) ação regional:

- Estimular as formas e os mecanismos institucionais de coordenação intermunicipal e regional para o planejamento e a gestão sustentada dos recursos naturais e dos serviços de interesse comum.

\section{Lei Complementar no. 580, de 19 de dezembro de 2008}

Institui o Código de Urbanismo e Meio Ambiente da Estância de Atibaia e dá outras providências.

Artigo 1‥ O ordenamento urbanístico e ambiental na Estância de Atibaia obedecerá aos termos deste Código.

Artigo 20. Constituem objetivos do ordenamento urbanístico e ambiental na Estância de Atibaia:

I - instrumentalizar a implantação das diretrizes e proposições para o desenvolvimento municipal expressas no Plano Diretor e, no que couber, as 
diretrizes e proposições dos planos específicos que integram o processo de planejamento permanente do Município;

II - estabelecer bases sistemáticas para o exercício do poder de polícia administrativa no que respeita ao urbanismo e ao meio ambiente no território municipal; (...)

IV - evitar a degradação ambiental e a deterioração do valor da terra;

V - minimizar os impactos negativos causados pelas ações humanas à estrutura de assentamento, aos recursos naturais, à biota, às conformações fisiográficas e ambientais em geral;

VI - promover a melhoria das condições de vida da população, contribuindo para a redução da segregação e da exclusão sociais e para a manutenção da integridade do meio ambiente;

VII - promover a democratização da utilização do espaço de assentamento, em especial o urbano;

VIII - garantir a função social da propriedade.

Artigo 17. Para os efeitos deste Código, ficam estabelecidas as seguintes categorias de uso do solo:

I - Residencial;

II - Industrial;

III - Comercial / Serviços;

IV - Especial I - Infraestrutura;

V - Especial II - Diversos.

Artigo 18. . As categorias de uso do solo estabelecidas no Artigo anterior ficam subdivididas nas subcategorias constantes do Anexo 04 que integra este Código.

Artigo 26․ Ficam as Áreas Urbanas do Município, para os fins deste Código, divididas em Zonas das seguintes categorias:

I-Residenciais;

II - Mistas;

III - Exclusivamente Econômicas;

IV - Especiais.

Artigo $27^{\circ}$. As subcategorias e finalidades das Zonas arroladas no Artigo anterior são as constantes do Anexo 06 deste Código. 
Artigo 29․ A realização de empreendimentos, a localização e o exercício das atividades no Município ficam sujeitas às restrições zonais de uso e ocupação constantes, respectivamente, dos Anexos 08 e 09 deste Código.

$\S 1 \%$. As restrições zonais de uso do solo incidem sobre os usos classificados conforme disposto no Anexo 04, e instituem, segundo as diferentes categorias de Zonas, as condições de uso Permitido, Proibido, e Permissível.

§ 2․ Uso Permitido é todo aquele que pode se dar em qualquer parte da Zona, não estando obrigado a qualquer comprovação adicional específica.

§ 3‥ Uso Proibido é todo aquele que não pode se dar em qualquer parte da Zona, não sendo passível de aceitação demonstração de particularidades ou atributos que possam justificá-lo.

§ 4‥ Uso Permissível é aquele cuja ocorrência poderá ser admitida pela autoridade municipal, desde que apresente atributos demonstrativos de sua possibilidade de localização na Zona, em igualdade de condições com os Usos Permitidos, com base em projeto técnico elaborado por profissional habilitado, considerando-se como atributos passíveis de consideração para tal finalidade:

I - índices urbanísticos e demais características dimensionais objeto de restrição zonal com valores superiores aos mínimos exigidos para a Zona;

II - adoção de soluções de infraestrutura energética, de telecomunicações, de saneamento básico, e de transportes, que minimizem os impactos urbanísticos e ambientais do uso pretendido;

III - tratamento ecologicamente adequado da cobertura vegetal, e sua ampliação, preferencialmente com uso de espécies nativas da região de Atibaia; (...)

Artigo 39․ Os Artigos desta Seção e os critérios constantes do Anexo 14 deste Código aplicam-se aos empreendimentos e atividades dependentes de licenciamento cuja localização se dê em áreas dotadas das seguintes configurações:

I - áreas de encosta;

II - áreas de solos instáveis e alagadiços;

III - áreas de fundos de vales e talvegues;

IV - áreas de preservação turística e ecológica; (...)

Artigo 40․ Todo empreendimento a ser implantado no território municipal deve, necessariamente, considerar a topografia do terreno e os caminhos naturais de escoamento das águas, mantendo-os o mais próximo possível das suas configurações originais. 
Parágrafo único. Os caminhos naturais de escoamento das águas deverão ser preservados por meio de canais a céu aberto, ressalvadas situações justificadamente excepcionais, caso em que, a critério da Administração Municipal e ouvido o Conselho Municipal de Defesa do Meio Ambiente - CONDEMA -, poderão ser utilizadas galerias tubulares.

Artigo 41‥ Não será permitida a realização de empreendimentos: (...)

II - em terrenos alagadiços;

III - na faixa de 30m (trinta metros) de largura, contados a partir do nível máximo atingido pelas águas, ao longo dos cursos d'água com largura inferior a 10m (dez metros); (...)

$\S 1$ 1․ Ficam proibidas quaisquer obras novas nas áreas referidas neste Artigo, inclusive de ampliação de construções já existentes em parcelamentos já implantados, salvo casos de interesse público e social e obras de conservação. (...)

Artigo 50․ Consideram-se restrições específicas associadas a áreas de conservação:

I - as que incidirem sobre áreas enquadradas como Unidades de Proteção Integral ou como Unidades de Uso Sustentável, nos termos da legislação federal que rege o Sistema Nacional de Unidades de Conservação - SNUC;

II - as que incidirem sobre áreas enquadradas como Áreas de Preservação Permanente - APP - nos termos do Código Florestal - Lei $\mathrm{n} \cong 4.771$, de 15 de setembro de 1965, alterada pela Lei $n^{0}$ 7.803, de 18 de julho de 1989 - e sua regulamentação dada pelas Resoluções CONAMA $n \cong 302$ e $n \cong 303$, ambas de 20 de março de 2002;

III - as que incidirem sobre áreas tombadas. (...)

Artigo 104‥ Este Código entra em vigor na data de sua publicação, revogadas as disposições em contrário, em especial, as Leis Complementares municipais no. 470, de 13 de julho de 2005; ํo. 480, de 14 de julho de 2005; e ํo. 565, de 20 de maio de 2008. 
ANEXO 06. Zoneamento - Características e finalidades das zonas

\begin{tabular}{|c|c|c|}
\hline $\begin{array}{c}\text { Zonas } \\
\text { (Código | Nome) }\end{array}$ & Características & Finalidades \\
\hline $\begin{array}{c}\text { ZR1 | } \\
\text { Exclusivamente } \\
\text { Residencial } 1\end{array}$ & $\begin{array}{l}\text { - Áreas de uso residencial absolutamente } \\
\text { caracterizado. } \\
\text { - Baixa densidade populacional (a menor } \\
\text { dentre todas as Zonas Residenciais). } \\
\text { - Pouca diversificação da tipologia das } \\
\text { edificações, caracterizada essencialmente } \\
\text { pela casa (residência unifamiliar isolada). }\end{array}$ & $\begin{array}{l}\text { - Áreas de baixa densidade populacional. } \\
\text { - Assegurar exclusividade de uso } \\
\text { residencial aos adquirentes de } \\
\text { propriedades na área. } \\
\text { - Assegurar condições de conforto } \\
\text { urbanístico e ambiental às moradias e } \\
\text { espaços públicos e privados da área. } \\
\text { - Garantir a conservação dos valores dos } \\
\text { imóveis existentes e habilitados na área. } \\
\text { - Estabelecer parâmetros superiores para a } \\
\text { formação de preços do mercado } \\
\text { imobiliário. }\end{array}$ \\
\hline
\end{tabular}

\begin{tabular}{|c|c|c|}
\hline $\begin{array}{c}\text { ZR2 | } \\
\text { Exclusivamente } \\
\text { Residencial } 2\end{array}$ & $\begin{array}{l}\text { - Áreas de uso residencial fortemente } \\
\text { caracterizado. } \\
\text { - Densidade populacional de baixa a média } \\
\text { (segunda menor dentre todas as Zonas } \\
\text { Residenciais). } \\
\text { - Alguma diversificação na tipologia dos } \\
\text { empreendimentos, mantida sempre a } \\
\text { atividade residencial unifamiliar. } \\
\text { - Admitida uma proporção muito baixa de } \\
\text { usos não residenciais, predominantemente } \\
\text { ligados às necessidades da população } \\
\text { residente. }\end{array}$ & $\begin{array}{l}\text { - Criar condições para diversificação dos } \\
\text { tipos de usos residenciais, abrindo opções } \\
\text { para oferta de imóveis acessíveis a faixas } \\
\text { de renda mais diversificadas que as } \\
\text { previstas em ZR } 1 . \\
\text { - Favorecer a localização nas proximidades } \\
\text { das áreas residenciais de usos não- } \\
\text { residenciais de natureza não econômica, } \\
\text { de interesse direto dos moradores. }\end{array}$ \\
\hline $\begin{array}{c}\text { ZR3 | } \\
\text { Predominantemente } \\
\text { Residencial }\end{array}$ & $\begin{array}{l}\text { - Áreas de uso residencial diversificado, já } \\
\text { comportando a atividade residencial } \\
\text { multifamiliar, com os tipos de } \\
\text { empreendimentos correspondentes.- } \\
\text { Densidade populacional média. } \\
\text { - Admitida proporção média de usos não- } \\
\text { residenciais predominantemente ligados às } \\
\text { necessidades diárias da população, com } \\
\text { alguma abertura para os mais } \\
\text { diversificados, de baixo grau de incômodo. }\end{array}$ & $\begin{array}{l}\text { - Dar condições para diversificação da } \\
\text { oferta de empreendimentos residenciais e } \\
\text { mistos não incompatíveis, mantida ainda a } \\
\text { predominância do uso residencial.- } \\
\text { Favorecer a oferta de comércio e serviços } \\
\text { de interesse direto dos moradores da área. }\end{array}$ \\
\hline $\begin{array}{l}\text { ZR4 | Residencial } \\
\text { Diversificada }\end{array}$ & $\begin{array}{l}\text { - Áreas de uso residencial bastante } \\
\text { diversificado, com possível forte presença } \\
\text { da atividade residencial multifamiliar, e } \\
\text { seus tipos correspondentes de } \\
\text { empreendimentos. } \\
\text { - Densidades populacionais de média a } \\
\text { alta. } \\
\text { - Admitido grau avançado de diversificação } \\
\text { de usos não- residenciais, de preferência } \\
\text { associados aos residenciais, e de } \\
\text { características não-incomodas. }\end{array}$ & $\begin{array}{l}\text { - Ampliar a oferta de áreas para localização } \\
\text { e funcionamento de atividades que possam } \\
\text { coexistir sem conflito com usos residenciais } \\
\text { em zonas residenciais. } \\
\text { - Acolher, no ordenamento urbanístico, } \\
\text { atividades não- residenciais existentes que } \\
\text { se situem em imóveis residenciais, sem } \\
\text { ocorrência de conflitos de vizinhança, e } \\
\text { sem impactos negativos ao assentamento } \\
\text { e ao meio ambiente. } \\
\text { - Favorecer a diversidade urbana nos } \\
\text { bairros residenciais, contribuindo para a } \\
\text { riqueza de intercâmbios entre segmentos } \\
\text { sociais diferenciados. }\end{array}$ \\
\hline ZM1 | Mista 1 & $\begin{array}{l}\text { - Áreas de predominância de uso não- } \\
\text { residencial, em condições de acomodar } \\
\text { sem conflitos usos residenciais. } \\
\text { - Densidade populacional média. } \\
\text { - Pequena diversificação de usos não- }\end{array}$ & $\begin{array}{l}\text { - Habilitar espaços para a localização de } \\
\text { usos econômicos que requeiram relativa } \\
\text { concentração e possam coexistir com usos } \\
\text { residenciais, sem conflitos de vizinhança e } \\
\text { sem impactos negativos ao assentamento }\end{array}$ \\
\hline
\end{tabular}




\begin{tabular}{cll}
\hline $\begin{array}{c}\text { Zonas } \\
\text { (Código | Nome) }\end{array}$ & Características & Finalidades \\
\hline & residenciais. & e ao meio ambiente. - Acolher no \\
& & ordenamento urbanístico concentrações de \\
& usos econômicos existentes que não \\
apresentem impactos urbanísticos e \\
ambientais negativos.
\end{tabular}

- Áreas de predominância de uso nãoresidencial, podendo coexistir com áreas residenciais diversificadas.

ZM2 | Mista 2 - Densidade populacional média a baixa.

- Diversificação de usos não- residenciais avançada.
- Assegurar condições locacionais para usos econômicos que requeiram relativo grau de concentração, apresentem grau médio de incômodo, podendo, ainda, conviver com usos residenciais.

- Assegurar condições locacionais para usos econômicos que requeiram relativo - Áreas de forte predomínio dos usos nãoresidenciais, podendo conviver, no limite, com usos residenciais, sem maiores estímulos ao aumento destes.

ZM3 | Mista 3 - Densidade populacional baixa.- Forte diversificação dos usos não- residenciais, podendo comportar alguns de características não- poluidoras, porem, com grau já elevado de incômodo. grau de concentração, apresentem grau avançado de incômodo, podendo conviver, no limite, desde que adotadas medidas especiais, com usos residenciais.Potencializar o aproveitamento de condições logísticas presentes no Município para localização de usos econômicos, assegurando aos mesmos possibilidades de concentração adequadas, sem riscos de conflitos de vizinhança com usos incompatíveis.

- Assegurar condições locacionais para

- Áreas para usos não-residenciais, admitidos estes, apenas, quando existentes, sobre áreas urbanizadas regularmente aprovadas.

- Possibilidade de localização de

EE1 |

Exclusivamente Econômica 1 estabelecimentos industriais e comerciais de porte pequeno a médio, já com grau avançado de incômodo, embora nãopoluidores.

- Densidade populacional baixa, resultante, apenas, do assentamento residencial porventura existente, em parcelamentos regularmente aprovados. usos econômicos que requerem relativo grau de concentração, apresentam grau avançado de incômodo, não sendo conveniente que convivam com usos residenciais.- Potencializar 0 aproveitamento de condições logísticas presentes no Município para localização de usos econômicos, assegurando aos mesmos possibilidades de concentração adequadas, sem riscos de conflitos de vizinhança com usos incompatíveis, privilegiando atividades dinâmicas, de alto poder multiplicador, de alto valor agregado, não poluidoras, e intensivas em uso de tecnologia.
- Áreas para usos não-residenciais, - Assegurar condições locacionais para admitidos estes, apenas, quando existentes, sobre áreas urbanizadas regularmente aprovadas.

- Áreas de localização apropriada para estabelecimentos industriais, comerciais, e no que couber, de serviços, de grande

EE2 |

Exclusivamente Econômica 2 porte, e de alto grau de incômodo, embora não- poluidores do meio ambiente.

- Áreas que reúnem condições para concentrações funcionais de estabelecimentos industriais, comerciais, e de serviços, de grande porte.

- Densidade nula ou muito baixa, resultante, apenas, do assentamento residencial existente, em parcelamentos regularmente aprovados.

- Assegurar condições locacionais para
usos econômicos que se beneficiam de alto
grau de concentração, apresentam grau
avançado de incômodo, não
necessariamente devido à poluição
ambiental, mas particularmente pelo porte.-
Potencializar o aproveitamento do
"corredor de exportação" da Rod. D. Pedro
I, que atravessa o Município, habilitando a
faixa ao longo do mesmo para a
concentração de usos não residenciais,
sem riscos de conflitos de vizinhança com
usos incompatíveis, privilegiando
atividades dinâmicas, de alto poder
multiplicador, de alto valor agregado, não
poluidoras, e intensivas em uso de
tecnologia.




\begin{tabular}{cc}
\hline Zonas & Características \\
(Código | Nome) & \\
\hline
\end{tabular}

- Preservar, como referencial histórico e cultural, o padrão de implantação da cidade de Atibaia, em acrópole, sobre a colina situada entre o vale do Rio Atibaia e

- Área que compreende o sítio histórico da colina de implantação, em acrópole, da cidade, e que requer preservação como elemento referencial, de identidade, e de memória, da coletividade.

ZE1 | Especial 1 (Centro Histórico)

- Área da maior concentração de ofertas diversificadas de indústria, comércio, e serviços, do Município, compreendendo, também, usos diversificados residenciais. os vales dos Córregos do Major e Itapetinga.- Abrir possibilidades de localização e exercício de atividades diversificadas na área preservada, sem alterações no perfil topográfico e visual do sítio original de implantação da cidade.Promover a valorização urbanística e funcional da área central da cidade, enfatizando seu papel como fator referencial e de identidade da população atibaiense.- Prover sustentabilidade à manutenção da área central como pólo de atração da população de Atibaia e região.

- Preservar as atividades rurais ainda existentes na borda interior da área urbana contínua.

- Áreas compreendidas entre as demais categorias de Zonas, e os limites das áreas urbanas, consideradas de menor prioridade para o assentamento, e para as, quais não existem desígnios específicos quanto ao uso e ocupação, nem, tampouco,

ZE2 | Especial 2 condições de dotação de infra- estrutura a (Reserva de curto prazo.

Assentamento Urbano)

- Áreas objeto de severas restrições de uso e ocupação corrente, abertas, porém, a iniciativas de mercado que impliquem em maior aproveitamento, desde que cada novo empreendimento reúna condições de absorver, no interior de sua delimitação, a totalidade dos impactos urbanísticos e ambientais que provoque.

- Permitir, sob condições especiais consistentes na absorção total, em nível do próprio empreendimento, dos impactos urbanísticos e ambientais eventualmente gerados - a realização de empreendimentos da indústria imobiliária e da construção civil que apresentem inovações em relação ao ordenamento urbanístico e às soluções de infraestrutura. - Abrir a possibilidade de localização de usos do solo que requeiram grandes extensões de terrenos para sua implantação e funcionamento, e que, por seu porte e nível elevado de operações de transporte e tráfego de pessoas e objetos, se beneficiem de condições de relativo isolamento em relação aos demais usos.

- Áreas dotadas de condições logísticas favoráveis ao aproveitamento com fins turísticos, podendo os usos do solo a estes

ZE3 | Especial 3 correspondentes conviver, sem conflito,

- Favorecer a implantação no Município, em especial nas áreas urbanas, de empreendimentos e atividades voltados para o turismo.

- Assegurar condições de continuidade, com usos de outra natureza.

(Predominantemente Turística)

- Áreas nas quais o uso para fins turísticos deverá ser privilegiado, demandando-se que os usos para outros fins reúnam expansão, e melhoria da qualidade da oferta de estabelecimentos de hotelaria e outros tipos de alojamento instalados no condições de compatibilidade com aqueles. Município.

\begin{tabular}{cll}
\hline & - Áreas destinadas basicamente ao manejo & \\
& aeroportuário. & - Assegurar reserva de espaços para \\
& - Por manejo aeroportuário entender-se-a & operação, diversificação, modernização e \\
ZE4 | Especial 4 & tanto as operações presentes quanto & aparelhamento do sistema aeroportuário do \\
(Reserva & eventuais relocalizações do parque & Município, prevenindo o dispêndio de \\
Aeroportuária) & aeroviário existente e conversão de seus & grandes volumes de recursos para fins de \\
& $\begin{array}{l}\text { equipamentos e instalações para outros } \\
\text { fins ligados ao desenvolvimento do }\end{array}$ & $\begin{array}{l}\text { remoção de usos impeditivos da } \\
\text { implantação de seus equipamentos. }\end{array}$ \\
& Município. & \\
\hline
\end{tabular}


ANEXO 14. Critérios aplicáveis segundo configurações específicas de sítio e meio ambiente

\begin{tabular}{|c|c|c|c|}
\hline \multirow{2}{*}{$\begin{array}{l}\text { Configuração } \\
\text { (compartimento } \\
\text { fisiográfico) }\end{array}$} & \multicolumn{2}{|c|}{ Objeto de Incidência } & \multirow{2}{*}{$\begin{array}{c}\text { Condições / Exigências } \\
\text { (critérios) }\end{array}$} \\
\hline & Empreendimentos & Incidência & \\
\hline
\end{tabular}

$(\ldots)$

ÁREAS DE

SOLOS

INSTÁVEIS E

- quaisquer

ALAGADIÇOS
- condicionada à apresentação de:

a) sondagens efetuadas no terreno, em quantidade suficiente para caracterizar as camadas do subsolo, acompanhadas de memorial;

b) projeto de drenagem e proteção dos taludes,
- apreciação de projetos de empreendimentos nestas áreas de modo a evitar a erosão e carreamento de matéria sólida em suspensão para as edificações ou logradouros vizinhos;

c) a critério do órgão competente, plano de execução do terrapleno, contendo os dispositivos de tratamento das fundações e dos aterros;

d) plano de proteção de terrapleno, até o período de implantação das edificações, ou de qualquer outro empreendimento que se venha a executar no terreno.

- dependentes de consideração como suficientes dos elementos exigidos, e merecedores de aprovação os planos e projetos mencionados na exigência anterior; - constatação, mediante vistoria no local, que

- aprovação de foram adotadas medidas no sentido de:

projeto e I - proteger os taludes em áreas não edificadas expedição do com revestimentos que dificultem os processos respectivo alvará erosivos;

de licença
II - evitar assoreamento dos sistemas drenantes existentes nas vizinhanças; - implicação na cassação automática da licença, sem prejuízo de aplicação de outras medidas cabíveis, no caso de desatendimento às medidas mencionadas na letra anterior.

\section{Lei Municipal no. 3.705, de 19 de dezembro de 2008}

Institui a Área de Proteção Ambiental - APA - Várzeas do Atibaia e dá outras providências.

Artigo 1‥ Fica criada a Área de Proteção Ambiental das Várzeas do Rio Atibaia, doravante designada como APA Várzeas do Atibaia, sujeita às normas gerais e regulamentações que nesta Lei são determinadas. 
Artigo 2. A instituição da APA Várzeas do Atibaia tem por objetivo contribuir para a estruturação ecologicamente sustentada do assentamento urbano no Município, de modo a: (...)

II - assegurar condições de espraiamento adequadas das águas correspondentes ao regime de cheias do Rio Atibaia, bem como às vazões associadas ao manejo específico da capacidade hídrica da bacia, com vistas ao abastecimento de populações da região de Atibaia e áreas vizinhas; (...)

IV - assegurar a proximidade de espaços abertos organizados e de elevada qualidade ambiental a todas as macrounidades de assentamento urbano do Município.

Parágrafo único. Para os efeitos desta Lei, consideram-se caracterizadas geomorfologicamente como várzeas as áreas constituídas de solos originários de decomposição de materiais transportados por cursos d'água ou trazidos das encostas pelo efeito erosivo das chuvas, geralmente planas, situadas às margens de córregos e rios, expostas à umidade e a processos químicos de redução, em consequência da elevação do lençol freático, estando sujeitas ou não a inundações periódicas.

Artigo 3‥ Para alcançar o objetivo estabelecido no Artigo 2ㅜ, a Administração Municipal diligenciará no sentido de prevenir o uso inadequado dos terrenos situados nas várzeas do Rio Atibaia e de seus afluentes, seja para fins urbanos, seja para fins rurais incompatíveis, assegurando, ao mesmo tempo, a criação de espaços e condições ecológicas para a realização de atividades de lazer, educação ambiental, apreciação da natureza, pesquisa científica, produção de mudas com vistas ao povoamento e reprodução de espécies vegetais nativas da região de Atibaia.

Artigo 4‥ A APA Várzeas do Atibaia é delimitada, no território municipal:

I - desde o limite municipal leste até o lago da Represa da Usina, em ambas as margens do Rio Atibaia, pela linha contínua de cota 747,50 (setecentos e quarenta e sete vírgula cinqüenta) metros do nível do mar, nos locais em que essa linha diste mais de 200,00 m (duzentos metros) contados a partir do eixo do rio, e pela faixa de $200,00 \mathrm{~m}$ (duzentos metros) contados a partir do eixo do rio nos locais em que a referida linha de cota se situe a menor distância; (...)

§ 1․ Para todos os efeitos, integram ainda a APA Várzeas do Atibaia o Rio Atibaia, seus afluentes e o lago da Represa da Usina. (...) 
Artigo 5o. Fica a Secretaria de Urbanismo e Meio Ambiente da Estância de Atibaia, ou órgão que venha a substituí-la em suas atribuições, responsável pela administração da APA Várzeas do Atibaia.

Artigo 7․ O Plano de Manejo da APA Várzeas do Atibaia será elaborado pelo Executivo Municipal, em conjunto com o COMDEMA, no prazo máximo de 24 (vinte e quatro) meses, contados a partir da data de publicação desta Lei, e conterá, necessariamente:

I - o zoneamento ecológico-econômico da área;

II - condições específicas para a constituição de parque urbano linear voltado ao lazer e à recreação, bem como para a frequência e uso da APA por parte da população;

III - as normas referentes ao uso e à ocupação das áreas que integram a APA, em conformidade com 0 zoneamento ecológico-econômico, incluindo a obrigatoriedade de realização de Estudo de Impacto Ambiental e respectivo Relatório - EIA/RIMA - em caso de empreendimentos com significativo impacto ambiental;

IV - usos e tratamentos dispensados à biota e ao relevo;

V - o sistema de gestão da APA;

VI - o dispositivo permanente de monitoramento da gestão da APA, integrado, segundo representações paritárias, por membros do Executivo e da sociedade civil.

Parágrafo único. Até que seja concluído o Plano de Manejo a que se refere o

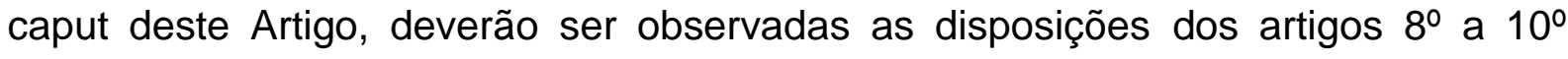
desta Lei.

Artigo 8‥ Fica estabelecido para a APA, em caráter geral, a ser detalhado no Plano de Manejo previsto no Artigo $7^{\circ}$ desta Lei, o zoneamento composto pelas seguintes áreas:

I - Áreas de Proteção Integral - API -, constituídas por todos os terrenos situados no território municipal contidos:

a) entre as margens do Rio Atibaia e a linha de cota 742,50 (setecentos e quarenta e dois vírgula cinqüenta) metros do nível do mar, bem como entre essa linha e a faixa de $200,00 \mathrm{~m}$ (duzentos metros) contados a partir do eixo do rio nos locais em que a referida linha de cota se situe a menor distância;

b) no entorno do lago da Represa da Usina, pela linha contínua de cota 742,50 (setecentos e quarenta e dois vírgula cinquenta) metros do nível do mar, nos locais 
em que essa linha diste mais 200,00 m (duzentos metros) contados a partir das margens do lago, e pela faixa de 200,00 m (duzentos metros) contados a partir das margens do lago, nos locais em que a referida linha de cota se situe a menor distância;

c) entre as margens dos afluentes do Rio Atibaia e a linha de cota 742,50 (setecentos e quarenta e dois vírgula cinquenta) metros do nível do mar;

II - Áreas de Transição - ATR -, constituídas por todos os terrenos situados entre os limites externos das Áreas de Proteção Integral descritas no Inciso anterior e a linha demarcatória da APA descrita no Artigo 4º desta Lei.

Parágrafo único. Superpõem-se às áreas descritas nos Incisos I e II deste Artigo as Áreas de Preservação Permanente - APP - nos termos do Artigo $3^{\circ}$ da Resolução CONAMA no 303, de 20 de março de 2002.

Artigo 9-. Ficam proibidos a implantação de empreendimentos e o exercício de atividades causadoras de degradação da qualidade ambiental das áreas integrantes da APA Várzeas do Atibaia, particularmente:

I - empreendimentos e atividades potencialmente poluidores das águas, do solo e do ar;

II - obras de terraplenagem e abertura de canais que importem em sensível alteração das condições ecológicas;

III - atividades capazes de provocar acelerada erosão das terras ou acentuado assoreamento nos corpos d'água; (...)

Artigo 10․ Nas áreas definidas no zoneamento geral da APA nos termos do Artigo 8o serão observadas as restrições constantes do Anexo II desta Lei.

Parágrafo único. Fica assegurada, em áreas de empreendimentos de parcelamentos regularmente aprovados até a data da promulgação desta Lei, situados no interior da APA, a montante do lago da Usina até a divisa municipal com os Municípios de Bom Jesus dos Perdões e Piracaia, nas áreas situadas entre a linha limítrofe da Área de Proteção Integral - API e a linha limítrofe das Áreas de Proteção Permanente - APP que prevê a legislação federal, a possibilidade de execução de edificações das categorias previstas e aprovadas para os referidos parcelamentos.

Artigo 11․ As disposições constantes desta Lei, bem como do Plano de Manejo previsto no Artigo $7^{\circ}$ serão consideradas concorrentes, no que couber, com as do ordenamento urbanístico e ambiental do Município, bem como com as que vierem a 
ser estabelecidas no Plano de Manejo da APA da Usina, criada pela Lei Estadual no 5.280, de 04 de setembro de 1986, prevalecendo, sempre, e em qualquer hipótese, as de maior restrição.

\section{Lei Orgânica do Município de Atibaia, de 23 de fevereiro de 2012}

Dispõe sobre a revisão e consolidação da Lei Orgânica Municipal.

Artigo 192․ O Município participará do sistema integrado de gerenciamento de recursos hídricos previsto no artigo 205 da Constituição Estadual, isoladamente, ou em consórcio com outros Municípios da mesma bacia ou região hidrográfica, assegurando para tanto, meios financeiros e institucionais.

Artigo 193․ Caberá ao Município, no campo dos recursos hídricos:

I - proceder ao zoneamento das áreas sujeitas a riscos de inundação, erosão e escorregamento do solo, estabelecendo restrições e proibições ao uso, parcelamento e à edificação, nas áreas impróprias ou críticas, de forma a preservar a segurança e a saúde pública; (...)

III - exigir, quando da aprovação dos loteamentos, completa infraestrutura urbana, correta drenagem das águas pluviais, proteção do solo superficial e a reserva de áreas destinadas ao escoamento de águas pluviais e às canalizações de esgotos públicos e em especial nos fundos de vale; (...)

Artigo 197‥ No estabelecimento das diretrizes e normas sobre o desenvolvimento urbano, e na elaboração do Plano Diretor serão asseguradas:

I - a compatibilização do desenvolvimento urbano e das atividades econômicas e sociais com as características, potencialidades, e vulnerabilidade do meio físico, em especial dos recursos hídricos, superficiais e subterrâneos;

II - a coerência das normas, dos planos e programas municipais, com os planos e programas estaduais da bacia ou região hidrográfica, de cuja elaboração participar o Município;

III - a utilização racional da água, do solo, e do ar, de modo compatível com a preservação e melhoria da qualidade da saúde pública e do meio ambiente, e com a eficiência dos serviços públicos de saneamento;

IV - a instituição de áreas de preservação das águas utilizáveis para abastecimento das populações e a implantação, conservação e recuperação das matas ciliares; 
V - a proteção da quantidade e da qualidade das águas, como uma das diretrizes do Plano Diretor, do zoneamento municipal e das normas sobre uso e ocupação do solo;

VI - a atualização e o controle do Plano Diretor e de suas diretrizes de forma periódica e sistemática, de modo compatível com os planos da bacia ou região hidrográfica. 